\title{
Physical Characterization of kato \\ Encoding Catalase HPI of \\ Escherichia coli
}

by

\section{Barbara Lynne Triggs-Raine}

\author{
A thes is \\ submitted to the Faculty of Graduate Studies \\ in partial fulfillment of the \\ requirements for the degree of \\ Doctor of Philosophy
}

Department of Microbiology

University of Manitoba

Winnipeg, Manitoba

1987 
The author has granted an irrevocable non-exclusive licence allowing the National Library of Canada to reproduce, loan, distribute or sell copies of his/her thesis by any means and in any form or format, making this thesis available to interested persons.
L'auteur a accordé une licence irrévocable et non exclusive permettant à la Bibliothèque nationale du Canada de reproduire, prêter, distribuer ou vendre des copies de sa thèse de quelque manière et sous quelque forme que ce soit pour mettre des exemplaires de cette thèse à la disposition des personnes intéressées.

L'auteur conserve la propriété du droit d'auteur qui protège sa thèse. Ni la thèse ni des extraits substantiels de celle-ci ne doivent être imprimés ou autrement reproduits sans son autorisation. 
PHYSICAL CHARACTERIZATION OF katG ENCODING CATALASE HP1

OF ESCHERICHIA COLI

BY

BARBARA LYNNE TRIGGS-RAINE

A thesis submitted to the Faculty of Graduate Studies of the University of Manitoba in partial fulfilment of the requirements of the degree of

\section{DOCTOR OF PHILOSOPHY}

(C) 1987

Permission has been granted to the LIBRARY OF THE UNIVERSITY OF MANITOBA to lend or sell copies of this thesis, to the NATIONAL LIBRARY OF CANADA to microfilm this thesis and to lend or sell copies of the film, and UNIVERSITY MICROFILMS to publish an abstract of this thesis.

The author reserves other publication rights, and neither the thesis nor extensive extracts from it may be printed or otherwise reproduced without the author's written permission. 
TO DARREN 


\section{AKNOWLEDGEMENTS}

Throughout my research program many people supported me with their guidance, friendship, and technical assistance. I am especially grateful to my supervisor, Dr. Peter Loewen who provided all of these things as well as the encouragement 1 needed to get through some major obstacles during my research.

I am also grateful to Dr. Harry Duckworth and to Dr. Lynda Donald for many helpful discussions, the gifts of HB101/PBR322 and M13mp18 DNA, and an invaluable crash course in DNA sequencing. Furthermore, 1 am indebted to Bill Taylor and Dr. Duckworth for doing the amino acid sequence, and to Jack Switala and Dr. Loewen for isolating HPI and the cyanogen bromide fragments for amino acid sequencing. Discussions and moral support provided by Dr. Glen Klassen and by Dr. Charles chow were appreciated. Thank you also to Tom Hobman for the gift of DAT153 DNA.

Thank you to my many friends in the department who provided an environment that made coming to work a pleasure, in particular Dave Boyd, Jack Switala, Mike Mulvey, Nancy Mohr, Pamela Sorby, Robert Hurta, Sally McNabb, Sharon Berg, and Teo Devos. These people were true friends, constantly providing support and assistance when 1 needed it. I could not have asked for a better group of friends to work with. I would also like to thank some $\mathrm{friends}$ from outside of the university who patiently put up with the excuse, "I have to work in the lab", cindy Nordick, the late Arlene Nightingale, Tulip and Henry Schnerch, Heather and Gerald Baete, and Katherine Newton.

To my family, my parents, and my sisters, Penny and Karen, I thank you for understanding when I had to say I was too busy because I had to study or 1 had to work in the $l a b$ and for providing me with unending moral support.

Finally, to Darren, for his patience during the long hours at the $l a b$, for $r$ ides back and forth to the lab at all hours, for giving me support in times of stress, for helping me with my thesis, and for encouraging me to strive to reach my career goals, I am eternally grateful. 
ABSTRACT 


\section{$1.0 \quad$ ABSTRACT}

Three loci affecting catalase activity in E. coli were identified by transposon Tn 10 mutagenesis, then mapped by interrupted mating and $P 1$ transduction. These loci were the same three that had been previously identified by nitrosoguanidine mutagenesis: katE at $37.8 \mathrm{~min}$, katf at $59 \mathrm{~min}$, and kat6 at $89.2 \mathrm{~min}$.

The Clarke and Carbon plasmid pLC36-19 had been isolated and shown to encode the structural gene for HPI catalase. In an attempt to localize the HPI gene within the large $19.2 \mathrm{~kb}$ insert of PLC36-19, transposon Tn5 insertions were made. Although none of the transposon insertions disrupted catalase activity, deletion mutagenesis of one transposon carrying plasmid, $P C 1$, localized the gene on a $3.8 \mathrm{~kb}$ Hindlll fragment. The Hindlll fragment was subcloned into PAT153 generating two catalase positive plasmids, PBT22 and PBT54, both containing the same insert but in opposite orientations. The ends of the gene were defined by a specific ECoR1 deletion at the $0 \mathrm{~kb}$ end and by BAL31 deletions at the $3.8 \mathrm{~kb}$ end. Maxicell analys is of the deletion plasmids suggested the promoter was at the $0 \mathrm{~kb}$ end and this was confirmed by subcloning a $320 \mathrm{bp} B g / 1$ fragment from the $\mathrm{O} \mathrm{kb}$ end into a promoter cloning vector. The gene on PBT22 coding for the HPI protein was shown by hybridization to be the same gene in which a transposon Tn 10 had been inserted and mapped as katG.

Fragments of katG were subcloned into $M 13 \mathrm{mp} 18 / 19$ and sequenced by dideoxy chain termination sequencing. Approximately $3 \mathrm{~kb}$ of the $3.8 \mathrm{~kb}$ Hindlll insert was sequenced and found to contain an open reading frame 
2181 bp in length. Potential Shine-Dalgarno and Pribnow box sequences Were found appropriately placed upstream from the open reading frame, and a potential terminator was found downstream. The open reading frame predicted a polypeptide of 726 amino acids having a molecular weight of 80049 daltons and an amino acid composition similar to those previously determined on the HPI protein. Several cyanogen bromide peptides of the HPI protein were partially purified and sequenced in an Edman sequenator. All of the peptide sequences were identified in the predicted amino acid sequence. The codon usage of the gene suggested it was highly expressed. No obvious homology with other catalase protein or DNA sequences was found and it was proposed that the HPI catalase was a unique hydroperoxidase unlike any others which have been previously sequenced.

The promoters of three mutant katG genes, two of which were suspected promoter mutants, were cloned and sequenced. The sequences were identical to the wild type gene suggesting that the two suspected promoter mutants may actually be mutants for the positive regulatory gene, oxy 
TABLE OF CONTENTS 
TABLE OF CONTENTS

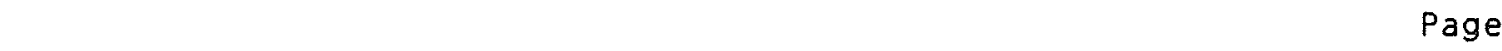

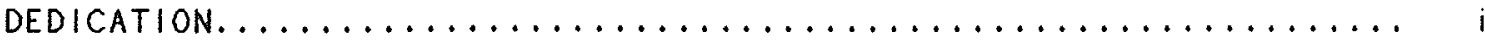

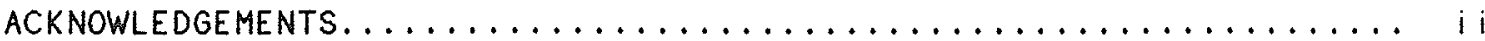

1.0 ABSTRACT................................

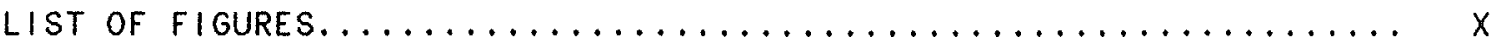

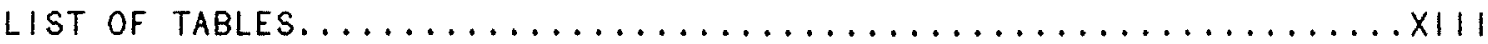

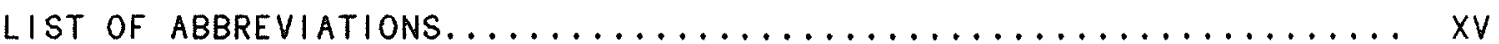

2.0 HISTORICAL...............................

2.4 Oxygen: Both Friend and Foe.....................

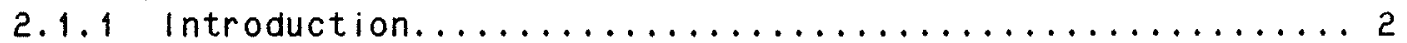

2.1.2 The Production of Toxic Oxygen Species.............. 3

2.1.3 The Targets of Toxic Oxygen Species................ 7

2.2 Protection From Toxic Oxygen Species.................. 8

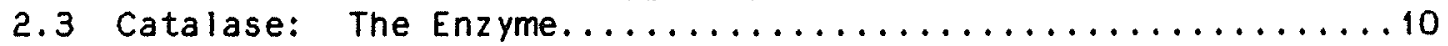

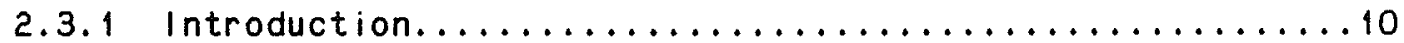

2.3.2 E. Coli Catalases HPI and HPII..................... 12

2.3.3 Comparison of E. coli Catalases HPI and HPII to Other

Catalases...............................

2.4 The Regulation of Catalase......................... 16

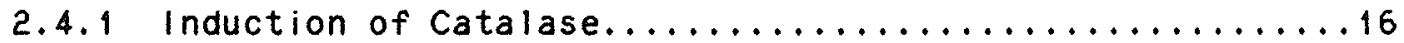

2.4.2 Is Catabolite Repression Involved In Catalase Synthesis?.19

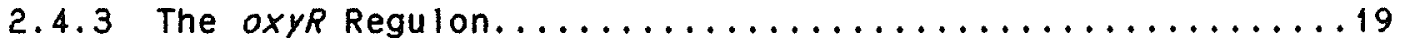

2.5 The Function of Catalase in $E$. coli...................22

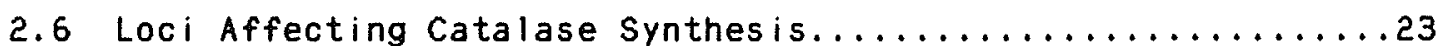

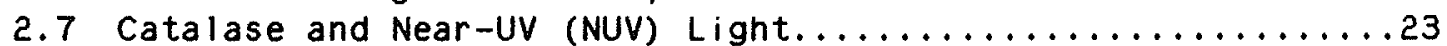

2.8 Catalase and spontaneous Mutagenesis..................25

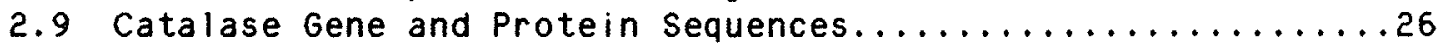

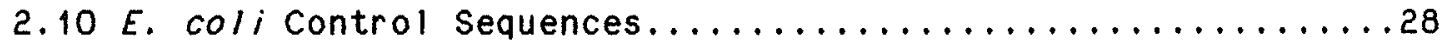

2. 11 Characterization of a Plasmid Encoding the HPI Catalase.....30

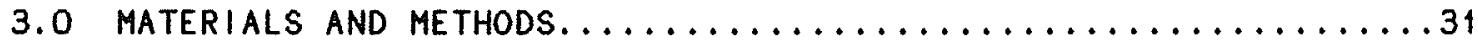

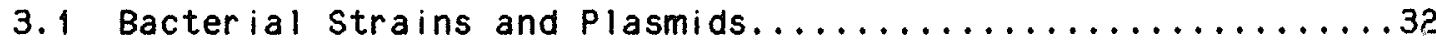

3.2 Standard Bacterial Growth Conditions, Media and Solutions....32

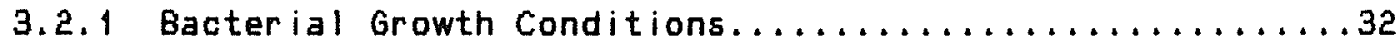

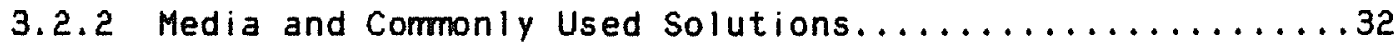

3.3 Measurement of DNA and Protein Concentrations................. 39

3.4 Isolation of Catalase Mutants by Nitrosoguanidine (NG)

Mutagenesis..............................40

3.5 Transposon Mutagenesis.......................40

3.5.1 Preparation of Transposon Carrying Phage Lysates.........40

3.5.2 Transposon Tn 10 Mutagenes is of MP180 and UM478.......44

3.5.3 Transposon Tn5 Mutagenes is of pLC36-19............42

3.6 Genetic Mapping of Chromosomal Genes.................. 42

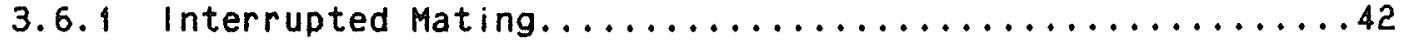

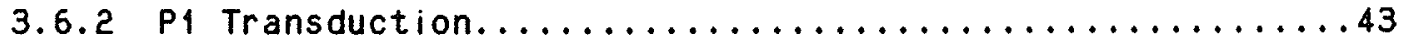

3.7 Assay of Catalase Activity........................ 44

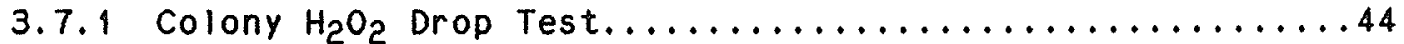

3.7 .2 Quantitation of Catalase by oxygraph................ 44

3.7.3 Catalase and Peroxidase Visualization on Polyacrylamide Gels...................................44

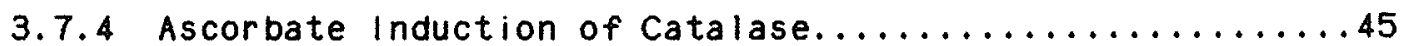

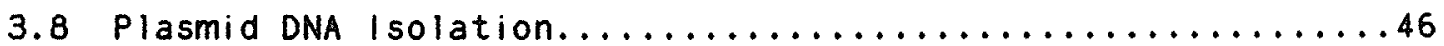

3.8.1 Plasmid Screening Preparations.................46 
3.8.2 Preparation of Plasmid DNA by the Alkaline Extraction

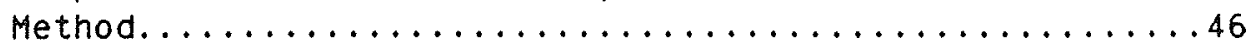

3.8.2.1 Small Scale Plasmid Isolation for Restriction Enzyme Digestion.............................. 46

3.8.2.2 Large Scale Plasmid I solation.................47

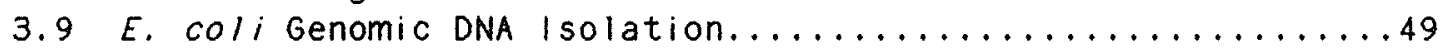

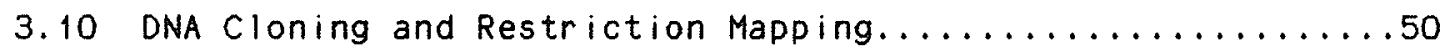

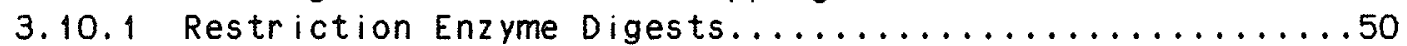

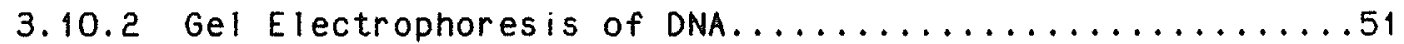

3.10.2.1 Preparation of DNA Samples................... 51

3.10.2.2 Agarose Gel Preparation and Electrophoresis........51

3.10.2.3 Preparation and Electrophores is of Acrylamide Gels..52

3.10.2.4 Staining, Photography, and Sizing of DNA Bands.....52

3.10.3 Alkal ine Phosphatase Treatment of DNA.............53

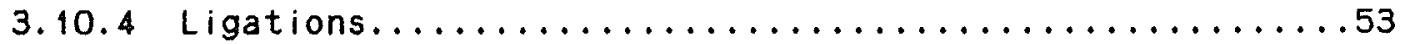

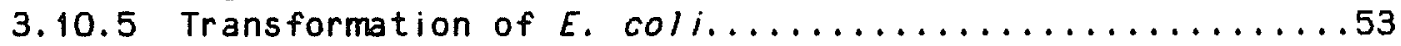

3.10.6 Screening for Plasmid Recombinants................ 54

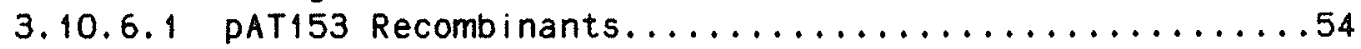

3.10.6.2 pKK232-8 Recombinants..................... 54

3.10.6.3 M13mp18/19 Recombinants...................55

3.10.7 Elution of DNA Fragments from Agarose Gels...........55

3.10.7.1 Elution of DNA Fragments for Restriction Enzyme

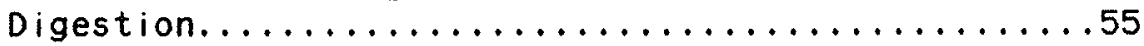

3.40.7.2 Elution of DNA Fragments for Nick Translation or

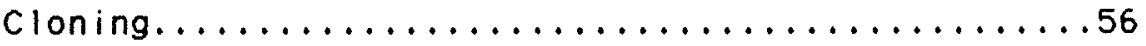

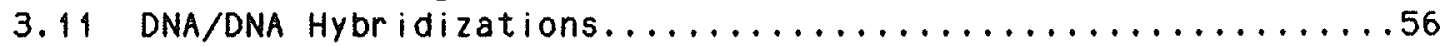

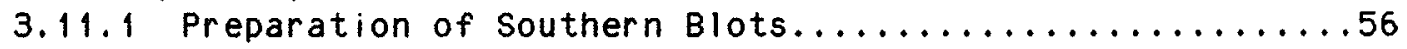

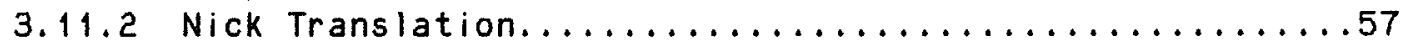

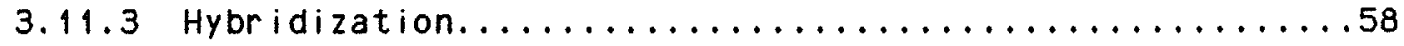

3.12 I solation of Plasmid Deletion Mutants..................59

3.12.1 Deletion of Specific Fragments from Plasmids..........59

3.12.2 BAL31 Deletion Mutagenes is of pBT22..............59

3. 13 Maxicell Analys is of Plasmid Encoded Polypeptides.........64

3. $14 \mathrm{HPI}$ Protein Purification and Analysis................62

3.44.4 Partial Purification of Catalase HPI...............62

3.14 .2 Immunodiffusion Analys is...................63

3. 44.3 SDS-Polyacrylamide Gel Electrophores is (PAGE) ........63

3.14 .4 Cyanogen Bromide Cleavage of HPI Catalase............64

3.14.5 Amino Acid Sequence Determination.................65

3.15 Dideoxy Chain Termination Sequencing.................65

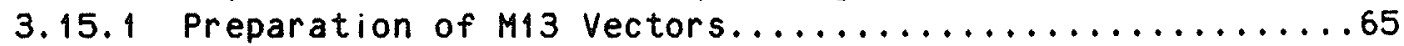

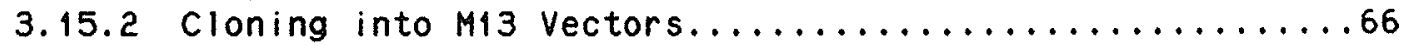

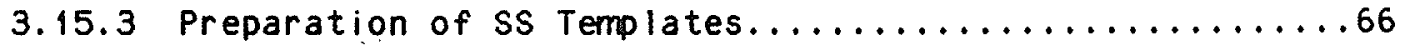

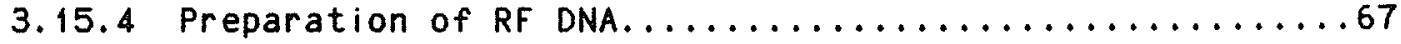

3.15.5 Preparation and Electrophores is of Sequencing Gels....67

3.15.6 Sequencing and T-Tracking SS Templates.............68

3.45.6.1 Reactions for T-Tracking 10 Clones..............69

3.15.6.2 Reactions for Sequencing SS Templates............70

3.15.7 Preparation for and Autoradiography of Sequencing Gels..70

3.15.8 Interpretation of the DNA Sequence................ 71

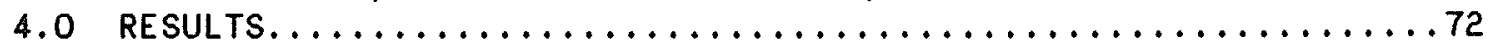

4.1 Genetic Mapping of Transposon Tn 10 Catalase Mutants.........73 4.1.1 Isolation, characterization, and Mapping of 
katE12: :Tn10 and katf13: :Tn10.................

4.1.2 Isolation, Characterization, and Mapping of katG17: :Tn 10.82

4.2 Isolation of Transformable Catalase Mutants...............85

4.2 .1 Isolation of Catalase Mutants by NG Mutagenesis........85

4.2 .2 Construction of UM262........................

4.3 Restriction Mapping of pLC36-19.................. 90

4.4 Isolation and Mapping of transposon Tn5 insertions in

pLC36-19.................................. 97

4.5 Localization of the HPI Coding Region by Deletion of $D C 1 \ldots . .98$

4.6 Cloning and Restriction Mapping of the Catalase Gene.......102

4.7 Definition of the Boundaries of the HPI Gene...........111

4.7.1 Definition of the $0 \mathrm{~kb}$ End by a specific EcoRI Deletion. 111

4.7.2 Cloning of a 7550 bp Sphl Fragment from pLC36-19......111

4.7.3 Definition of the $3.8 \mathrm{~kb}$ End of the Gene by BAL31

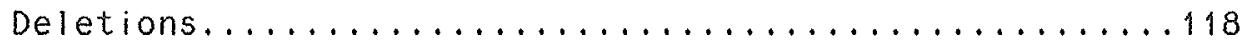

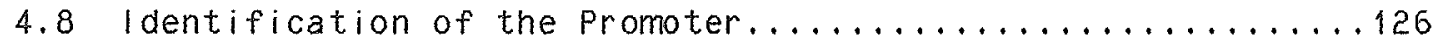

4.8.1 Immunodiffusion Analysis of Partially Purified HPI.....126

4.8.2 Maxicell Analys is of Plasmid Encoded Polypeptides...... 129

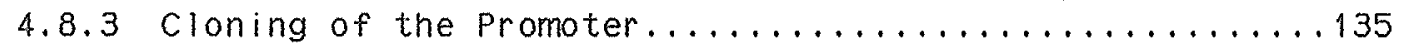

4.9 Identification of the structural Gene for HPI as katG......140

4.10 The Sequencing of katG and Analysis of This Sequence........146

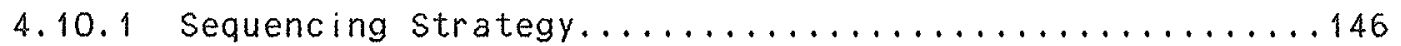

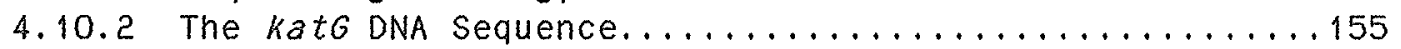

4.10 .3 Control Sequences of the katG Gene................162

4.10.5 Confirmation of the Predicted HPI Amino Acid Sequence. 166 4.10.5.1 Sequencing of Cyanogen bromide Peptides from HPI...166

4.10.5.2 Molecular Weight Determination and Amino Acid

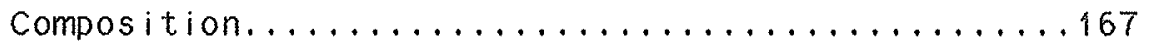

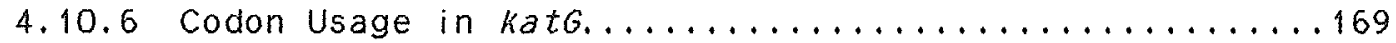

4.10.7 Comparison of HPI to Other Catalase and Peroxidase

Proteins..............................171

4.10.8 Cloning and Sequencing of Potential kato Mutant

Promoters.............................. 174

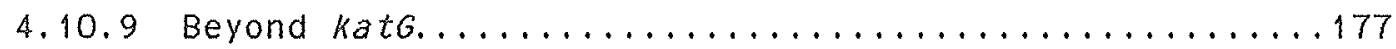

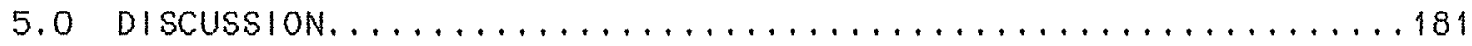

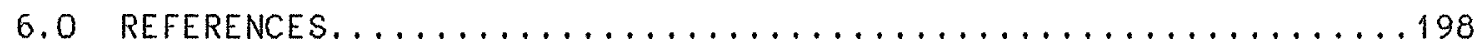


LIST OF FIGURES 


\section{LIST OF FIGURES}

Figure 1. The electron transport chain typical of E. coli grown

Page

under aerobic conditions...................... 5

Figure 2. Visualization of catalase and peroxidase in crude extracts of MP180 and the transposon Tn 10 derivatives UM120, UM122,

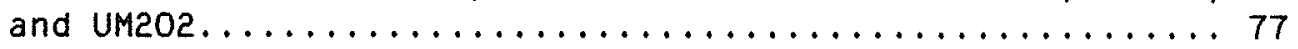

Figure 3. Determination of time of entry for katE12::Tn 10 and

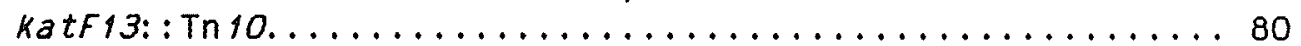

Figure 4a. Genetic map of $E$. coli $k 12$ based on $100 \mathrm{~min} . . . \ldots \ldots . \ldots 84$

Figure $4 b$. Genetic map orienting katG relative to other nearby

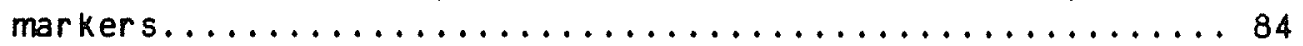

Figure 5. Restriction map of pLC36-19.................. 96

Figure 6. Restriction maps of $\mathrm{pCl}$ and Hindlll deletion derivatives

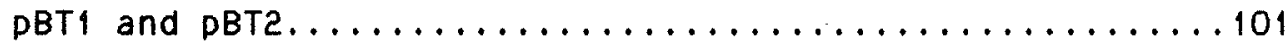

Figure 7. Hindll restrictions showing the presence of a $3.8 \mathrm{~kb}$ fragment in PBT2 not found in PBT1................ 104

Figure 8. Visualization of catalase and peroxidase activities in UM228 and the plasmid containing derivatives UM228/pBT22

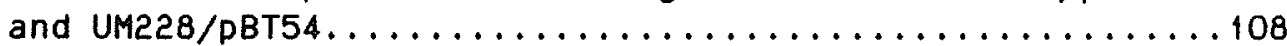

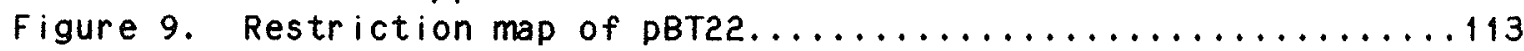

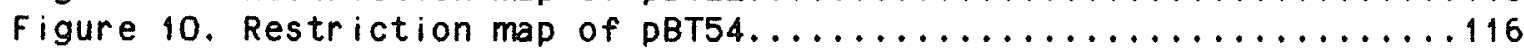

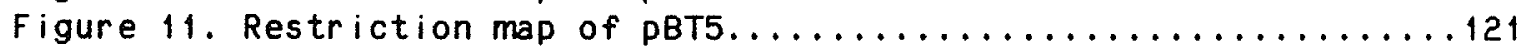

Figure 12. Localization of katG by deletion mapping of pBT5, pBT24, pBT28, pBT29, and pBT30..................... 123

Figure 13. Determination of protein concentrations and catalase activity in fractions collected from a DEAE-Sephadex

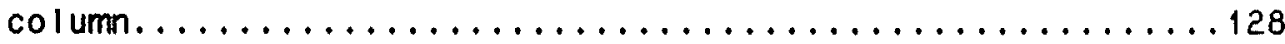

Figure 14. Immunodiffusion analys is of crude catalase preparations with anti-HPI................................. 131

Figure 45. Maxicell analys is of plasmid encoded polypeptides.......133

Figure 16. Restriction enzyme digests identifying the 320 bp Bg/l। fragment cloned into the promoter cloning plasmid pKK232-8 and confirming the orientation of the promoter to be the

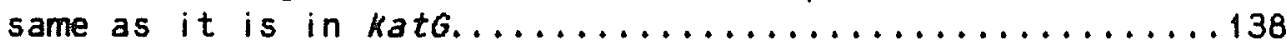

Figure 17. Restriction map of pGprmt..................... 142

Figure 18. Autoradiogram of the change in hybridization pattern when genomic DNA with or without a transposon Tn10 insertion in katG was digested with Hincll and probed with

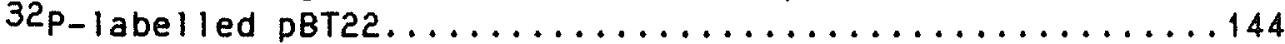

Figure 19. Restriction map of transposon $\operatorname{Tn} 10 . \ldots \ldots \ldots \ldots \ldots \ldots \ldots 148$

Figure 20. The multiple cloning regions of the M13mp18 and M13mp19

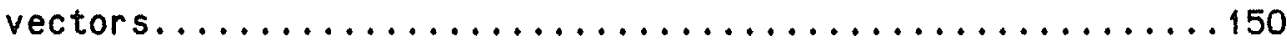

Figure 21. The sequencing strategy of kat6.................... 152

Figure 22. Photograph of a portion of an autoradiogram of a sequencing

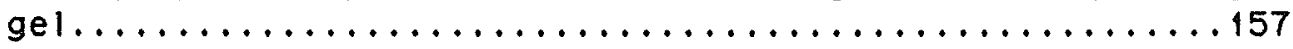

Figure 23. The katG DNA sequence and the HPI predicted amino acid sequence.................................. 159

Figure 24. The control sequences of the kat6 gene................ 164

Figure 25. Hydrophilicity plots of a) the $E$. coli HPI catalase and b) bovine liver catalase...................176 
Figure 26. The DNA and predicted amino acid sequences of the region sequenced beyond the termination sequence of katG.......479 
xiii

LIST OF TABLES 


\section{LIST OF TABLES}

Page

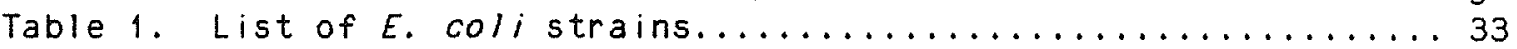

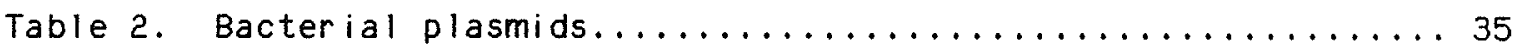

Table 3. Catalase levels in Tn 10 generated catalase mutants and their parents............................. 74

Table 4. Effect of ascorbate on catalase levels of various strains.. 75

Table 5. Mapping of KatE12: :Tn10 and Katf13::Tn10 by P1 transduction 81

Table 6. Mapping of katG17::Tn 10 by $P 1$ transduction............86

Table 7. Catalase activities of nitrosoguanidine mutants......... 88

Table 8. Effect of ascorbate on catalase levels of HB101 and UM228.. 89

Table 9. Restriction fragments obtained by digestion of pLC36-19... 92

Table 10. Restriction enzyme fragments obtained by digestion of ColEl DNA....................................... 94

Table 11. Restriction enzyme fragments used to map Tn5 insertions in pLC36-19..................................999

Table 12. Restriction fragments generated from pBT2, pLC36-19, and

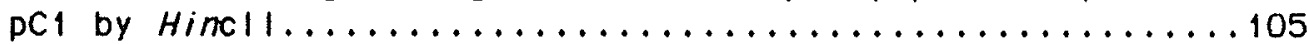

Table 43. Restriction enzyme fragments generated from pBT22.......109

Table 14. Restriction fragments of pBT22 sized on acrylamide gels and used to order restriction enzyme sites............110

Table 15. Restriction enzyme fragments generated from pBT54.......144

Table 16. Catalase activity in log phase UM53 containing various plasmids................................117

Table 17. Restriction enzyme fragments generated from pBT5........119

Table 18. Restriction enzyme fragments used to map pBT28, PBT29,

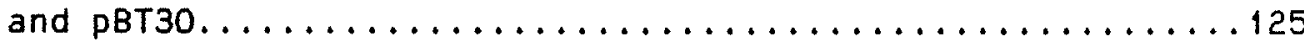

Table 19. Restriction fragments generated from pGprm1 ...........139

Table 20. Fragments cloned into M13mp18/19 for sequencing katG......153

Table 21. Amino acid sequence of cyanogen bromide generated peptides

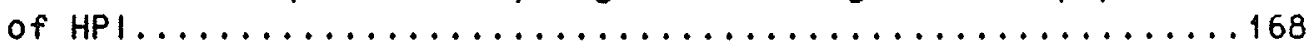

Table 22. Amino Acid composition of catalase proteins...........170

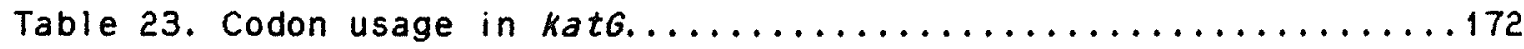


LIST OF ABBREVIATIONS 


\section{LIST OF ABBREVIATIONS}

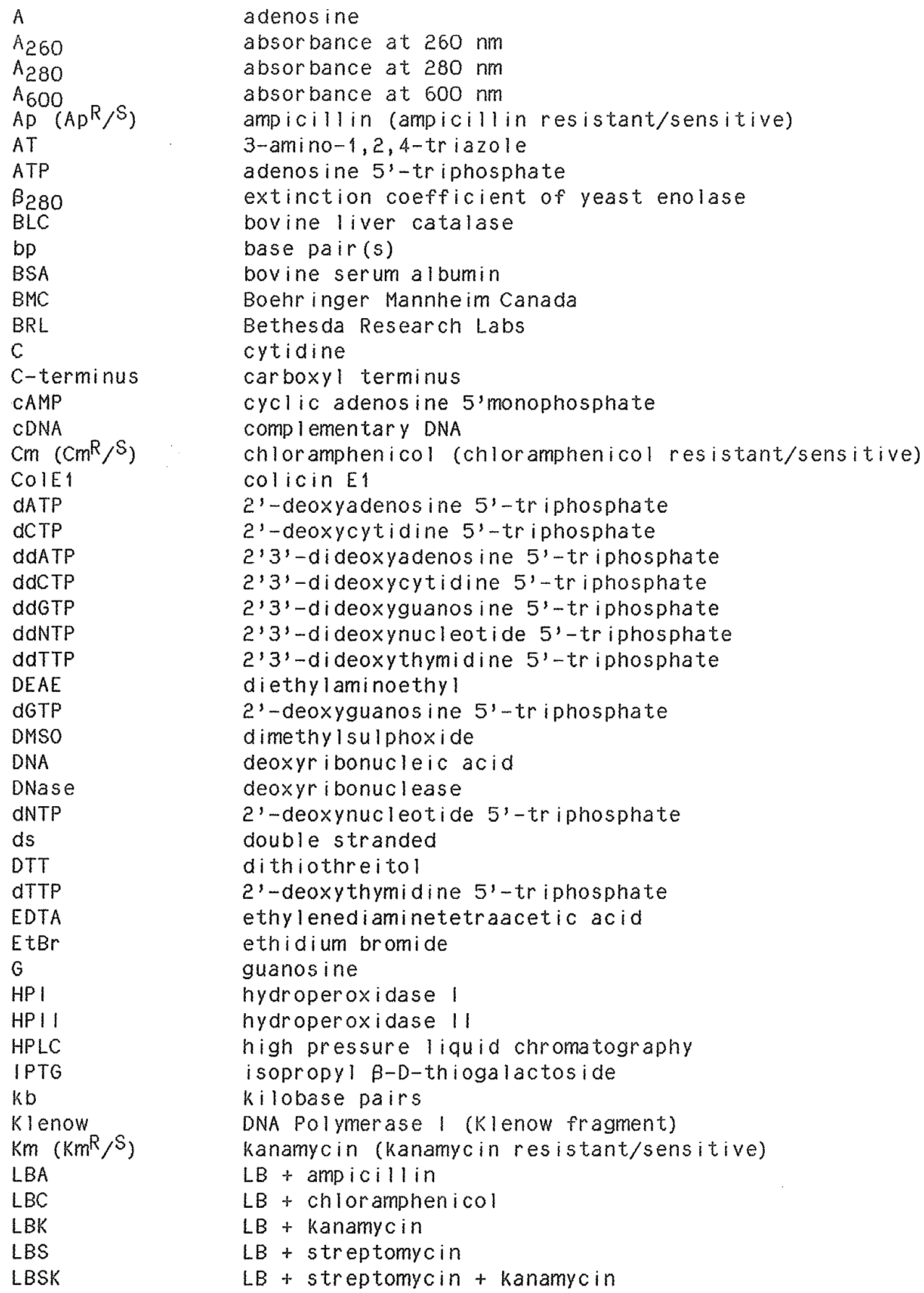




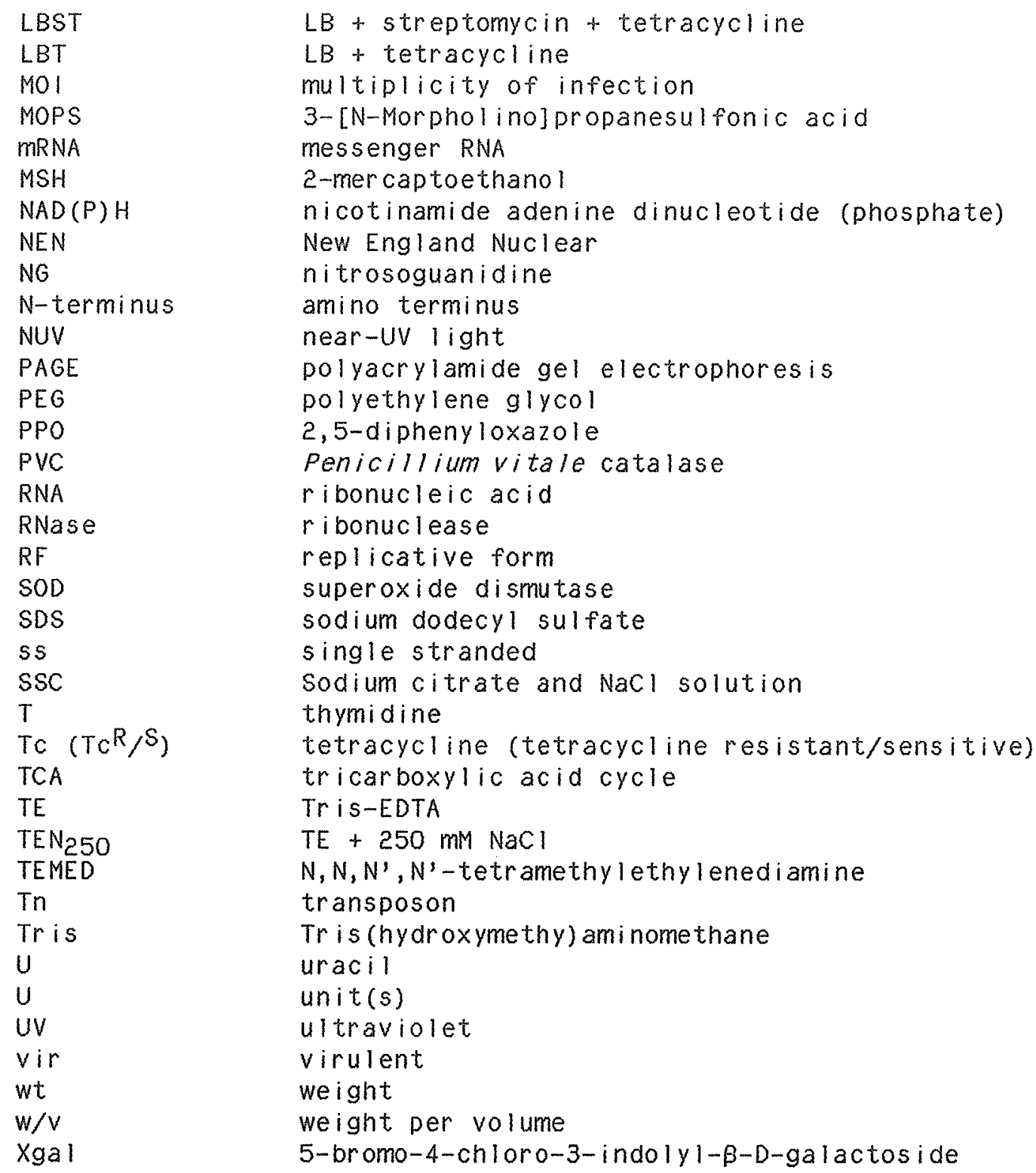


HISTORICAL 


\subsection{HISTORICAL}

\subsection{Oxygen: Both Friend and Foe}

\subsubsection{Introduction}

Organisms benefiting from the efficiency of aerobic respiration must also deal with the consequences - toxic oxygen species. During aerobic respiration, the sequential reduction of oxygen to water leads to the production of the superoxide anion radical $\left(\mathrm{O}_{2}^{-}\right)$, hydrogen peroxide $\left(\mathrm{H}_{2} \mathrm{O}_{2}\right)$, and the hydroxyl radical $(\mathrm{OH} \cdot)$ (Fridovich, 1978), the same intermediates thought to mediate the oxygen dependent toxicity of ionizing radiation (Moody and Hassan, 1982; Sammartano and Tuveson, 1984).

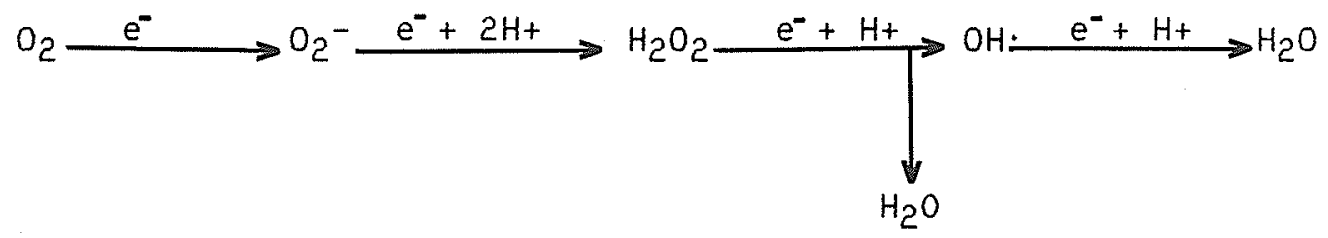

(Fridovich, 1978)

Recent evidence showing that these species may play a significant role in aging and cancer (reviewed in Halliwell and Gutteridge, 1985) has renewed interest in the study of the mechanisms of oxygen toxicity and cellular protection from toxic oxygen species. In Escherichia coli and Salmonella typhimurium, oxygen is now recognized as a serious environmental stress capable of eliciting a global protective response (Christman et al., 1985). The generation of dangerous oxygen species in biological systems and the protective mechanisms which have evolved in response to them are discussed in subsequent sections. This is followed by a closer look at 
catalase, its regulation, and potential function in Escherichia coli.

The physical characterization of catalase genes and proteins, and

finally, E. coli gene expression, are reviewed as an introduction to the

physical characterization of the E. coli catalase gene, katG.

\subsubsection{The Production of Toxic Oxygen Species}

Many cellular components and processes are responsible for the

generation of toxic oxygen species. Although aerobic respiration

accounts for a significant portion of intracellular toxic oxygen species

(Fridovich, 1977), other factors such as the presence of certain

transition metals (reviewed by Halliwell and Gutteridge, 1985), y-rays

(Van Hermen and Meuling, 1975), x-rays (Sammartano and Tuveson, 1984),

near-UV light (Sammartano and Tuveson, 1984), radiomimetic drugs (Breimer

and Lindahl, 1985), and certain enzymes (Halliwell and Gutteridge, 1985)

can directly contribute to or augment the production of toxic oxygen species.

The efficiency of aerobic respiration is based on the ability of the organism to carry out oxidative phosphorylation. The generation of ATP by oxidative phosphorylation requires the passage of electrons from a reduced electron carrier, commonly $\mathrm{NADH}$, through an electron transport chain to the terminal electron acceptor, oxygen. The electron transport chain typical of $E$. coli is illustrated in Figure 1. The passage of electrons through this chain is necessary to allow the passage of protons across the membrane, capturing the energy as the electrons are passed from compounds of very negative $E_{0}^{\prime}$ 's to compounds with less negative $E_{0}^{\prime}$ 's in the form of a proton motive force which can then be coupled to the formation of ATP according to the chemiosmotic theory (Mitchell, 1979).

The chemistry of oxygen dictates its sequential reduction. 
Figure 1. The electron transport chain typical of E. coli grown under aerobic conditions. (Haddock and Jones, 1977) 


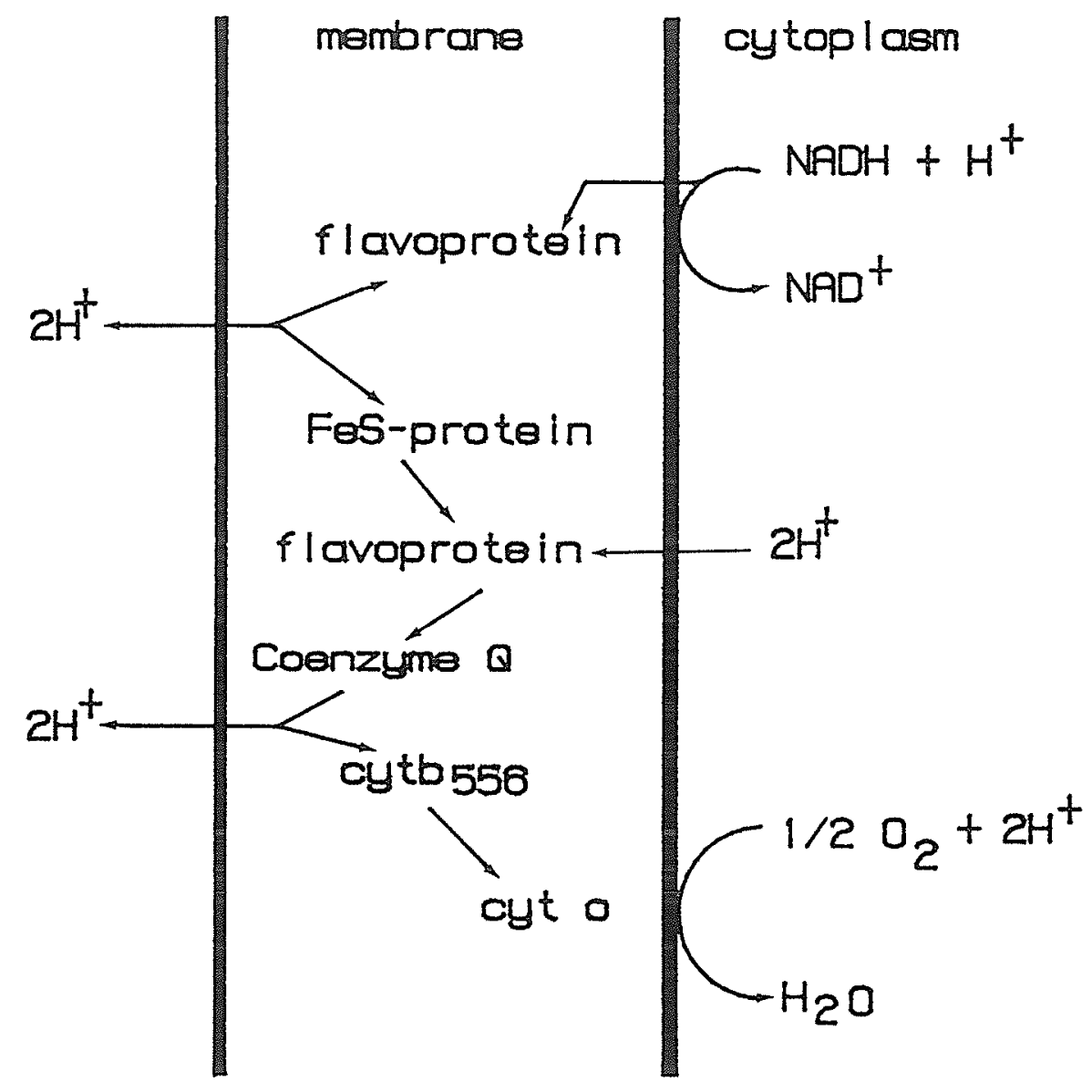


oxygen's unpaired electrons in the $\pi^{*}$ arbitals are of parallel spin and thus require two electrons of antiparallel spin to reduce them (Fridovich, 1977). The Pauli exclusion principle states that electrons occupying the same orbital must be of equal and opposite spin (Dickerson et al., 1979), making it impossible for two electrons of the same spin to be passed to axygen simultaneously. These restrictions make $\mathrm{O}_{2}$ relatively unreactive, but the loss of single electrons during electron transport can lead to the formation of the toxic intermediates $\mathrm{O}_{2}-\mathrm{H}_{2} \mathrm{O}_{2}$, and $\mathrm{OH} \cdot$. Cytochrome oxidase, the complex involved in the transfer of electrons to the terminal acceptor, usually oxygen, is very efficient and loss of electrons rarely occurs at this point. The most common points of loss are in the transfers leading to coenzyme $Q$ and from coenzyme $Q$ itself (Halliwell and Gutteridge, 1985).

Although $\mathrm{O}_{2}^{-}$is a product in biological systems that directly attacks many cellular targets (Bilinski, 1985; Fridovich, 1986), it is generally accepted that the secondary products of $\mathrm{O}_{2}^{-}$are the major mediators of oxygen toxicity. The production of $\mathrm{O}_{2}^{-}$always leads to the production of $\mathrm{H}_{2} \mathrm{O}_{2}$, and these two species, $\mathrm{O}_{2}^{-}$and $\mathrm{H}_{2} \mathrm{O}_{2}$, can then react to form the highly reactive product $\mathrm{OH}$ (Fridovich, 1977). Singlet $\mathrm{O}_{2}\left(\mathrm{O}_{2}\left[{ }^{1} \Delta \mathrm{g}\right]\right)$ is also a dangerous oxygen species produced in biological systems by the photosensitization of certain molecules, but under normal conditions, $\mathrm{O}_{2}\left[{ }^{1} \Delta \mathrm{g}\right]$ is not produced in significant quantities.

The hydroxyl radical is considered the most dangerous of the toxic oxygen species (Beauchamp and Fridovich, 1970). As stated above, $\mathrm{OH}$. can result from the reaction of $\mathrm{H}_{2} \mathrm{O}_{2}$ and $\mathrm{O}_{2}^{-}$. The likely mechanism involved is the Haber-Weiss reaction, a specific example of the Fenton reaction 
where $\mathrm{O}_{2}$ - acts as the reductant for the metal (Winterbourn, 1983). Other compounds such as ascorbate can also reduce fe(111).

$$
\begin{array}{ll}
\text { (1) } \mathrm{O}_{2}^{-}+\mathrm{Fe}\left(\mathrm{II} \longrightarrow \mathrm{O}_{2}+\mathrm{Fe}(11)\right. \\
\text { (2) } \mathrm{Fe}\left(\mathrm{II}+\mathrm{H}_{2} \mathrm{O}_{2} \longrightarrow \mathrm{Fe}(\mathrm{III})+\mathrm{H}_{2} \mathrm{O}+\mathrm{OH} .\right. \\
\text { (1) }+ \text { (2) } \mathrm{O}_{2}^{-}+\mathrm{H}_{2} \mathrm{O}_{2}+\mathrm{H}^{+} \longrightarrow \mathrm{O}_{2}+\mathrm{H}_{2} \mathrm{O}+\mathrm{OH} .
\end{array}
$$

(Halliwell, 1982)

The accessibility of the metal ions in biological systems is controversial (Fee, 1982), but it has been suggested that these metais are widely available (Halliwell et al., 1983; Fridovich, 1986).

Ionizing radiation (x-rays, y-rays, and UV light) has also been linked to $\mathrm{OH}$. mediated oxygen dependent $\mathrm{killing}$ ( $\mathrm{Halliwell}$ and Gutteridge, 1985). In E. coli, studies on the oxygen dependent effects of ionizing radiation have focused on near-UV (300-400 $\mathrm{nm}$ ) radiation (Tyrrel1, 1985; Sammartano and Tuveson, 1984; Eisenstark and Perrot, 1987). This will be discussed in more detail in section 2.7.

\subsubsection{The Targets of Toxic Oxygen Species}

Reactive oxygen species attack many biological molecules, including membrane fatty acids, proteins, and DNA. Imlay and Linn (1986) have proposed that the respiration rates of higher organisms may be related to the rates of age related deterioration. The reactions of toxic oxygen species in biological systems have been reviewed (Halliwell and Gutteridge, 1985).

The extremely reactive hydroxyl radical is capable of attacking almost any biological molecule. It can abstract protons from molecules such as membrane lipids, forming $\mathrm{H}_{2} \mathrm{O}$, and generating a new free radical which can go on to react with other molecules. Singlet oxygen is also known to cause free radical chain reactions among membrane fatty acids 
(Patterson, 1981).

Cellular proteins are another target of toxic oxygen species. The oxidation of methionine, tryptophan, histidine, and cysteine eventually leads to enzyme inactivation. Even $\mathrm{H}_{2} \mathrm{O}_{2}$ which is less reactive than $\mathrm{OH}$ or $\mathrm{O}_{2}\left[{ }^{1} \Delta \mathrm{g}\right]$ can attack and oxidize thiol groups of proteins, leading to enzyme inactivation.

There is a large accumulation of evidence demonstrating that DNA is a target of toxic oxygen species. Oxygen is known to cause genetic damage (Joenge et al., 1983). Paraquat, for example, which produces $\mathrm{O}_{2}{ }^{-}$ is mutagenic, causing both basepair substitutions and frameshift mutations (Moody and Hassan, 1982). Plumbagin, a quinone that diverts electrons from the electron transport chain to oxygen is also mutagenic (Farr et al., 1985).

The ability of $\mathrm{H}_{2} \mathrm{O}_{2}$ to cause DNA strand scission was demonstrated by Ananthaswamy and Eisenstark (1977). Other studies have also shown that $\mathrm{H}_{2} \mathrm{O}_{2}$ in combination with $\mathrm{O}_{2}^{-}$causes DNA strand scission (Farr et al., 1985), probably by the formation of $\mathrm{OH}$, a major species involved in oxygen toxicity. Ionizing radiation, radiomimetic drugs, and normal aerobic respiration all lead to the formation of $\mathrm{OH}$. which can cause ss and ds DNA breaks (Breimer and Lindahl, 1985). Armel et al. (1977) found that $90 \%$ of the DNA damage due to ionizing radiation was the result of the hydroxyl radical, $\mathrm{OH}$.

\subsection{Protection From Toxic Oxygen Species}

The accumulation of oxygen in the earth's atmosphere during the precambrian era forced organisms to evolve defense mechanisms for protection from toxic oxygen species. The resulting defense mechanisms 
were diverse, and the various levels of oxygen tolerance exhibited by bacteria have formed one of the bases of procaryotic classification. Obligate anaerobes, which cannot survive in the presence of oxygen lack protective enzymes and must sequester themselves in anaerobic environments for survival. All other organisms are aerobes containing various complements of protective enzymes which permit them to tolerate or even thrive in the presence of normal oxygen levels.

The Gram negative, facultative anaerobe, Escherichia coli has been the subject of a great deal of study on protection from oxidative damage. E. coli has two levels of defense, the predamage defense system which removes toxic oxygen species before they harm cellular components, and a postdamage defense system which repairs damage resulting from toxic oxygen species (Yonei et al., 1987). The enzymes traditionally recognized as part of the predamage defense system include superoxide dismutases, catalases, and peroxidases. These enzymes protect cells by removing $\mathrm{H}_{2} \mathrm{O}_{2}$ and $\mathrm{O}_{2}$ - before they can form toxic secondary oxygen species. The reactions catalyzed by the protective enzymes superoxide dismutase $(S O D)$, catalase, and peroxidase are given below.

$$
\begin{array}{rrr}
\text { Superoxide dismutase } \mathrm{O}_{2}^{-}+\mathrm{O}_{2}^{-}+2 \mathrm{H}^{+} \longrightarrow \mathrm{H}_{2} \mathrm{O}_{2}+\mathrm{O}_{2} \\
\text { Catalase } \quad \mathrm{H}_{2} \mathrm{O}_{2}+\mathrm{H}_{2} \mathrm{O}_{2} \longrightarrow 2 \mathrm{H}_{2} \mathrm{O}+\mathrm{O}_{2} \\
\text { Peroxidase } & \mathrm{H}_{2} \mathrm{O}_{2}+\mathrm{RH}_{2} \longrightarrow 2 \mathrm{H}_{2} \mathrm{O}+\mathrm{R}
\end{array}
$$

(Fridovich, 1978)

The presence of $S O D$ in nearly all aerobes confirms its role as a major oxidative defense. Elevated SOD levels correlated with increased resistance to $\mathrm{O}_{2}$ and $\mathrm{O}_{2}$-producing compounds ( $\mathrm{Fr}$ idovich, 1986). However, SOD is not essential because $E$. coli sodA sodB mutants can survive aerobically (Touati, in press) and there are aerobes that contain no SOD 
such as Lactobacillus plantarum, Neisseria gonorrhoeae, and Mycoplasma (Fee, 1982). However, the absence of SOD is usually compensated for in some way such as the accumulation of $\mathrm{Mn}^{++}$(Halliwell, 1982) or an elevated catalase level. The importance of SOD is further exemplified by the conservation of SOD protein sequences (Sato et al., 1987).

The ability of E. coli catalase mutants to grow normally at standard oxygen concentrations (Loewen, 1984), and the existence of many aerobes which lack catalase, show that catalase is also not essential to aerobes. Like SOD deficient cells, cells lacking catalase usually have a compensatory enzyme such as NADH peroxidase (Yousten et al., 1975;

Padgett and King, 1986). The importance of catalase to the organism is demonstrated by the sensitivity of catalase mutants to $\mathrm{H}_{2} \mathrm{O}_{2}$ (Loewen, 1984) and the resistance to $\mathrm{H}_{2} \mathrm{O}_{2}$ exhibited by catalase overproducers (Chr istman et al., 1985).

There are a number of enzymes which have been implicated in postdamage repair of oxidatively damaged DNA. In E. COli, DolA or polC (DNA Polymerases 1 and 111; Hagensee and Moses, 1986), recA (Car Isson and Carpenter, 1980), and $x$ thA (exonuclease 111; Demple et al., 1983) mutants are more sensitive to $\mathrm{H}_{2} \mathrm{O}_{2}$ than wild type cells. Imlay and Linn (1986) have found that some polA recB strains are not even aerotolerant. These $\mathrm{H}_{2} \mathrm{O}_{2}$ and $\mathrm{O}_{2}$ sensitivities infer a role for these genes in the repair of oxidatively damaged DNA.

\subsection{Catalase: The Enzyme}

\subsubsection{Introduction}

Catalase was one of the first bacterial enzymes to be characterized and later crystallized (Herbert and Pinsent, 1948). Catalase $\left(\mathrm{H}_{2} \mathrm{O}_{2}: \mathrm{H}_{2} \mathrm{O}_{2}\right.$ 
oxidoreductase E(1.11.1.6) is responsible for the decomposition of $\mathrm{H}_{2} \mathrm{O}_{2}$

to oxygen and water. Some catalases have an associated peroxidase

activity (donor: $\mathrm{H}_{2} \mathrm{O}_{2}$ oxidoreductase $\mathrm{ECl} .11 .1 .7$ ) that reduces $\mathrm{H}_{2} \mathrm{O}_{2}$ to

water using various organic compounds as electron donors.

The dismutation of $\mathrm{H}_{2} \mathrm{O}_{2}$ by catalase is a two stage reaction. In the first step, $\mathrm{H}_{2} \mathrm{O}_{2}$ reacts with the heme group of the enzyme to form compound 1:

$$
\mathrm{H}_{2} \mathrm{O}_{2}+\mathrm{Fe}-\mathrm{E} \longrightarrow \mathrm{H}_{2} \mathrm{O}+\mathrm{O}=\mathrm{Fe}-\mathrm{E} \text { (Compound I) }
$$

Compound 1 can then react with $\mathrm{H}_{2} \mathrm{O}_{2}$ in the catalatic mode or with other organic donors in the peroxidatic mode:

$$
\mathrm{H}_{2} \mathrm{O}_{2}+\mathrm{O}=\mathrm{Fe}-\mathrm{E} \longrightarrow \mathrm{H}_{2} \mathrm{O}+\mathrm{O}_{2}+\mathrm{Fe}-\mathrm{E} \text { (Compound II) }
$$

The peroxidase reaction usually occurs when $\mathrm{H}_{2} \mathrm{O}_{2}$ is at a low concentration (Vainshtein et al., 1986). Compound 1 is the site of aminotriazole inhibition which will be referred to in subsequent sections.

The catalase enzymes isolated from various sources, such as animals, plants, and bacteria usually have many common features. They contain four identical subunits that form a tetramer with a molecular weight between 225000 and 270000 . Each subunit is usually associated with one protoheme $I X$ group and acts as an independent unit (Schonbaum and Chance, 1976). Typical catalases have a broad pH optimum and are sensitive to inhibition by 3-amino-1,2,4-triazole (AT).

Bovine liver catalase, human catalase, and rat liver catalase are nearly identical (see section 2.9) and have the structure of a typical catalase. Catalases isolated from maize (Skadsen and Scandalios, 1986) and Drosophila melanogaster (Nahmias and Bewley, 1984) also have typical catalase structures. A number of fungal and bacterial catalases, 
including those from Neurospora crassa (Jacob and Orme-Johnson, 1979), Saccharomyces cerevisiae (Seah et al., 1973; Seah and Kaplan, 1973), Penicillium vitale (Vainshtein et al., 1986), Escherichia coli (see section 2.3.2), Proteus mirabilis (Jouve et al., 1984), Rhodospirillum rubrum (Nadler et al., 1986), Comamonas compransoris (Nies and Schlegel, 1982), Rhodopseudomonas capsulata (Nadler et al., 1986), Lactobacillus plantarum (Kono and Fridovich, 1983a; 1983b), Mycobacterium avium (Mayer and Kalkinbam III, 1986), Thermoleophilum album (Allgood and Perry, 1986), Bacillus larvae (Dingman and Stahly, 1984), Rhodopseudomonas spheroides (Clayton, 1959), and Micrococcus Iysodeikticus (Herbert and Pinsent, 1948) have been partially or in some cases fully purified and characterized. Many of the bacterial and fungal catalases are atypical and some unique features of these enzymes will be discussed in section 2.3 .3 with comparison to the E. coli catalases.

\subsubsection{E. coli catalases HPI and HPII}

The E.coli catalases hydroperoxidase I (HPI) and hydroperoxidase II (HPII) have been purified and characterized (Claiborne and Fridovich, 1979; Claiborne et al., 1979; Loewen and Switala, 1986). $H P I$, one of two electrophoretically distinct $E$, coli catalases, was first identified as an activity which copurified with the E. coli dianisidine peroxidase (Claiborne, 1978). The copurification led to the realization that HPI was a bifunctional enzyme having both catalase and broad spectrum peroxidase activity. Further physical characterization (Claiborne and Fridovich, 1979) revealed that HPI was composed of four identical 84000 dalton subunits ( 78000 by SDS-PAGE) which combined to form a 337000 dalton tetramer containing two protoheme $1 \times$ groups. Gel 
filtration chromotography and SDS-PAGE by Loewen and Switala (1986) gave apparent subunit molecular weights of 81000 and 84000 respectively, agreeing well with previous HPI studies. On native polyacrylamide gels run in Tris-glycine buffer, HPI separated into two isoenzyme forms labelled $\mathrm{HPI}-\mathrm{A}$ and $\mathrm{HPI}-\mathrm{B}$, the significance of which is presently unclear (Loewen et al., 1985a; Meir and Yagil, 1985).

Claiborne and Fridovich (1979) found HPI to have optimum catalase activity at $\mathrm{pH} 7.5$, optimum peroxidase activity at $\mathrm{pH} 6.5$, and a $\mathrm{km}$ (at $\mathrm{pH} 7.5)$ of $3.9 \mathrm{mM} \mathrm{H}_{2} \mathrm{O}_{2}$. Some other interesting properties of HPI were its resistance to inhibition by $A T$, and its heat lability at $70^{\circ} \mathrm{C}$ (Meir and Yagil, 1985). Analys is of the HPI protein showed that the protein contained no cysteine and it was concluded that there were no disulfide linkages between subunits (Claiborne and Fridovich, 1979). Cyanogen bromide cleavage of HPI suggested that it contained 13-14 methionine residues (Claiborne et al, 1979).

HPII catalase migrated much more slowly than HPI on native polyacrylamide gels and had no associated peroxidase activity (Loewen and Triggs, 1984). The characterization of this enzyme (claiborne et al., 1979) showed that it was composed of four 78000 dalton subunits, having a combined molecular weight of 312000 . The spectrum of the enzyme and its reduced hemochromagen revealed that the HPII associated prosthetic group was not protoheme $\mid X$. Loewen and Switala (1986) found HPII to be a hexamer composed of six identical 90-92 000 dalton subunits and having a combined molecular weight of 532000 . Each subunit was associated with an unusual heme group which had the properties of a dihydroporphyr in or chlor in type heme, similar to those of heme $d\left(a_{2}\right)$. The reasons for the differences between the HPII characterizations of these two groups are 
presentiy unknown.

Loewen and Switala (1986) found HP/I to have optimal catalase activity over a broad pH range ( $\mathrm{pH} 4-11)$. Using an indirect approach where HPI and HPII were separately inactivated, Meir and Yagil (1985) found HPII to have two $\mathrm{pH}$ optima, one at $\mathrm{pH} 6.8$ and one at $\mathrm{pH} 10.5$. In contrast to the HPI protein, HPII was sensitive to AT, resistant to $70^{\circ} \mathrm{C}$, had a $\mathrm{Km}$ of $18.2 \mathrm{mM} \mathrm{H} \mathrm{H}_{2}$, and was resistant to $0.1 \%$ SDS or $7 M$ urea (Meir and Yagil, 1985), the latter property also having been confirmed by Loewen and Switala (1986).

Characterization of HPI and HPII showed that these enzymes were unrelated, contradicting a previous suggestion that HPII was derived from HPI (Hassan and Fridovich, 1978). HPIl did not cross react with antisera prepared against HPI (Loewen et al., 1985b) nor did HPI cross react with antisera prepared against HPII (Claiborne et al., 1979). There were no similarities between the pattern of cyanogen bromide peptides produced from HPI and HPII (Claiborne et al., 1979).

\subsubsection{Comparison of E. coli Catalases HPI and HPII to Other Catalases}

The properties of the E. coli catalases HPI and HPII are not typical of the previously characterized catalases. However, many of the atypical features have been observed in other bacterial and fungal catalases. A discussion of these features and the catalases of other organisms exhibiting these properties follows.

HPI catalase has a tetrameric structure with a larger molecular weight than most tetrameric catalases. Neuraspora crassa (Jacob and Orme-Johnson, 1979) and Penicillium vitale (Vainshtein et al., 1986) catalases are large in size as well, and the dimeric catalase of Comamanas compransoris has a similar subunit molecular weight (Nies and 
Shlegel, 1982). Another unusual feature of HPI is its associated broad range peroxidase activity. Most catalase associated peroxidase activity allows the oxidation of only short chain organic alcohols and acids such as ethanol and formate, while broad spectrum peroxidases can oxidize a variety of compounds including pyrogallol and dianisidine. Broad spectrum peroxidase activities have also been associated with catalases from Thermoleophilum ablum (Allgood and Perry, 1986), Mycobacterium avium type-T (Mayer and Kalkinbam, 1986), and Rhodopseudomonas capsulata (Nadler et al., 1986). Unlike other catalases, HPI was not sensitive to inhibition by AT, a property shared by $R$. capsulata catalase (Nadler et al., 1986), M. avium type-T catalase (Mayer and Kalkinbam, 1986), and T. aloum catalase (Allgood and Perry, 1986). Although most catalases have a broad pH optimum, HPI had a specific optimum of $\mathrm{pH} 6.8$ like $R$. capsulata (Nadler et al., 1986) and C. compransoris (Nies and Schlegel, 1982) catalases. Nadler et al. (1986) recommended the formation of a new group of catalases containing E. coli HPl, R. capsulata catalase, M. avium type-T catalase, and $C$. compransoris catalase. It was surprising that the Proteus mirabilis catalase had no associated peroxidase activity but resembled the mamalian enzyme very closely (Jouve et al., 1984), since both $P$. mirabilis and $E$. coli are members of the Enterobacteriaceae family.

HPII also shows a variety of atypical properties. It is a monofunctional enzyme with a hexameric structure. Kono and Fridovich (1983b) described a pseudocatalase (non-heme) from Lactobacillus plantarum which was hexameric. Another notable difference between HPII and other catalases is that it contains a heme d like prosthetic group very similar to that of Neurospora crassa (Jacob and Orme-Johnson, 
1979). In many other ways HPII conforms to the characteristics of a typical catalase similar to the type-M catalase of M. avium (Mayer and Kalkinbam, 1986). They are both heat stable and sensitive to inhibition by AT (Mayer and Kalkinbam, 1986; Meir and Yagil, 1985). The Rhodospirillum mubrum catalase (Nadler et al., 1986) is also sensitive to AT, and $\mathrm{pH}$ independent between $\mathrm{pH} 5.5$ and 10 .

Like E. coli, both Mycobacterium avium (discussed above) and Saccharomyces have two types of catalase. Catalase A and $T$ in yeast have pH optima at pH 6-8 and pH 9.5, ( Seah and Kaplan, 1973) similar to HPI and HPII of E. coli (Meir and Yagil, 1984). Catalase A (Cohen et al., 1985) and $T$ ( Hartig and Ruis, 1986) from yeast have been cloned, and do not cross hybridize with each other.

Although this is not an exhaustive comparison of the catalases characterized to date, it does illustrate the diversity of oxidation protective enzymes which have evolved in procaryotic and lower eucaryotic organisms.

\subsection{The Regulation of Catalase}

\subsubsection{Induction of Catalase}

Catalase levels in E. coli are affected by the composition of the growth medium, the growth phase of the culture, and other factors (Yosphe-Purer and Henis, 1976). Catalase can be induced in E. coli and S. typhimurium by $\mathrm{H}_{2} \mathrm{O}_{2}$ or compounds that generate $\mathrm{H}_{2} \mathrm{O}_{2}$ as a secondary product.

The induction of catalase by $\mathrm{H}_{2} \mathrm{O}_{2}$ was first described in $S$. typhimurium (Finn and Condon, 1975) then later demonstrated in E. coli (Yosphe-Purer et al., 1977; Hassan and Fridovich, 1978; Richter and 
Loewen, 198i). The addition of compounds that generated $\mathrm{H}_{2} \mathrm{O}_{2}$ to cuitures also resulted in the induction of catalase. Pyocyanine which produced $\mathrm{H}_{2} \mathrm{O}_{2}$ was shown to induce catalase (Hassan and Fridovich, 1980) and later ascorbic acid which reacts with oxygen in the presence of metal ions to produce dehydroascorbate and $\mathrm{H}_{2} \mathrm{O}_{2}$ (Morgan et al., 1976), was shown to induce catalase in mid-log phase E. coli cultures (Richter and Loewen, 1981). Richter and Loewen (1981) found that the addition of ascorbate at concentrations between $0.57 \mathrm{mM}$ and $5.7 \mathrm{mM}$ to aerated cultures of $E$. coli caused an eight fold increase in catalase activity. Furthermore, chloramphenicol interfered with the catalase induction, demonstrating the requirement of protein synthesis for catalase induction. It has been suggested that $\mathrm{H}_{2} \mathrm{O}_{2}$ may activate a positive regulator or inactivate a negative regulator of catalase synthesis (Loewen et al., 1985a) and recently a $\mathrm{H}_{2} \mathrm{O}_{2}$ inducible positive regulator, oxyR has been described (Christman et al., 1985). The oxyR function will be discussed in detail in section 2.4.3.

Catalase induction by cysteine, an $\mathrm{H}_{2} \mathrm{O}_{2}$ generating compound, has been demonstrated in Pseudomonas fluorescens although $1.5 \mathrm{mM} \mathrm{H}_{2} \mathrm{O}_{2}$ itself did not act as an inducer (Himelbloom and Hassan, 1986).

Catalase activity has been observed to increase as $E$. coli enters stationary phase (Loewen and Triggs, 1984; Meir and Yagil, 1984). Finn and Condon (1975) observed that the specific activity of catalase decreased during log phase growth of Enterobacter aerogenes, Salmonella typhimurium, Serratia marcescens, Haemophilus influenzae, Rhodopseudomonas spheroides, and saccharomyces cerevisiae, then increased as the cells entered stationary phase. The increase into stationary phase coincided with a decrease in the $\mathrm{pH}$ of the medium. Bacillus larvae 
had no catalase during log phase growth but activity increased as it entered stationary phase and decreased once again during sporulation (Dingman and Stahly, 1984).

In E. coli it was known that there were two distinct catalase activities, HPI and HPII, but the relationship of these two activities to the regulation of catalase was difficult to interpret since the activities of the two catalases could not be completely separated in vivo. Loewen and Triggs (1984) were partially successful in differentiating $\mathrm{HPI}$ and $\mathrm{HPI}$ I by assaying with two different $\mathrm{H}_{2} \mathrm{O}_{2}$ concentrations, HPI having a much lower $\mathrm{Km}$ than HPII; there was still a great deal of "spillage" of one activity to the other. Loewen et al. (1985a) later differentiated the two activities by isolating transposon mutants deficient in either HPI or HPII activity. The HPI activity was inducible by ascorbate or $\mathrm{H}_{2} \mathrm{O}_{2}$ while $\mathrm{HPIl}$ was responsible for the increase in catalase activity as cells entered stationary phase. HPII showed no response to ascorbate and HPI did not increase during stationary phase. HPII levels were also found to be 5-10 fold higher during mid-log phase growth on TCA cycle intermediates and there was an apparent correlation between the increased synthesis of catalase and the levels of the TCA cycle enzymes. HPII levels were not influenced by whether or not active electron transport was occurring, contradicting a previous suggestion that components of the $E$. coli respiratory chain were linked to catalase levels (Hassan and Fridovich, 1978). Meir and Yagil (1984) found that $\mathrm{H}_{2} \mathrm{O}_{2}$ induced the $\mathrm{pH} 6.8$ catalase activity (corresponding to HPI) but that the $\mathrm{pH} 10.5$ activity (corresponding to HP/I) remained constitutive, indirectly confirming the independent induction of HPI and HPII. 


\subsubsection{Is Catabolite Repression Involved In Catalase Synthes is?}

The presence of glucose in the medium lowers the levels of catalase. Catabolite repression has been suggested to be involved in catalase expression in yeast (Sulebele and Rege, 1968), Bacteriodes fragilis (Gregory et al., 1977), and E. coli (Hassan and Fridovich, 1978; Yoshpe-Purer et al., 1977) Richter and Loewen (1982) showed that glucose did not inhibit catalase nor did CAMP enhance basal or induced catalase levels, refuting the involvement of catabolite repression in catalase expression.

Morgan et al.(1986) confirmed that glucose affects catalase by demonstrating lower HPI MRNA levels in the presence of glucose. Although glucose may lower the catalase levels, this was not a case of classical catabolite repression as glucose still affected cpd cya mutants (lacking the ability to generate CAMP) of S. typhimurium (Eisenstark and Perrot, 1987). The role of glucose in the inhibition of catalase remains unresolved.

\subsubsection{The oxyR Regulon}

Global regulons responding to phosphate starvation, DNA damage, heat shock and aerobic-anaerobic shift have been identified in E.coli (Gottesman, 1984). A regulon responding to oxidative stress recently identified in S. typhimurium and E. coli will be discussed in this section.

The presence of a regulon responding to oxidative stress was implicated by the ability of E. coli (Demple and Halbrook, 1983) and S. typhimurium (Winquist et al., 1984) to adapt to $\mathrm{H}_{2} \mathrm{O}_{2}$ by a process different from the sos or alkylation response. Christman et al. (1985) 
induced resistance to $10 \mathrm{mM} \mathrm{H}_{2} \mathrm{O}_{2}$ by pretreating 5 . typhimurium with $60 \mathrm{NM}$ $\mathrm{H}_{2} \mathrm{O}_{2}$ for $60 \mathrm{~min}$. This was a chloramphenicol sensitive response, demonstrating the requirement for protein synthesis in the development of resistance. Cells pretreated with $\mathrm{H}_{2} \mathrm{O}_{2}$ were also resistant to other chemical oxidants such as $\mathrm{N}$-ethylmaleimide and heating at $50^{\circ} \mathrm{C}$. Two dimensional (2-D) electrophoresis of the pretreated cells revealed the induction of 30 proteins, twelve of which reached maximal synthes is 10 minutes after $\mathrm{H}_{2} \mathrm{O}_{2}$ treatment, and eighteen of which reached maximal synthesis 10-20 min from the time of $\mathrm{H}_{2} \mathrm{O}_{2}$ addition. Catalase HPI was identified as one of the twelve proteins induced early.

Christman et al. (1985) isolated an $\mathrm{H}_{2} \mathrm{O}_{2}$ resistant mutant, oxyR1 which constitutively overexpressed $n$ ine of the twelve early proteins. It was also resistant to several chemical oxidants, certain organic hydroperoxides, and heating at $50^{\circ} \mathrm{C}$. Using 2-D electrophores is five of the overexpressed proteins were identified as HPI-A (D69), HPI-B (D71), a novel NAD(P)H alkylhydroperoxidase (F52 and C22), and the dnak (C69) protein. HPII was not induced by $\mathrm{H}_{2} \mathrm{O}_{2}$ or overexpressed in oxyRf mutants. A number of the proteins induced by oxidative stress could be induced by other stresses such as naladixic acid and ethanol. The overlap of stress responses was further substantiated by the fact that 5 of the 30 oxidative stress proteins are also heat shock proteins, three of which were identified as the dnak protein, groEL protein, and $N A D(P) H$ alkylhydroperoxidase (Morgan et al., 1986). The oxyR gene (mapping at 88 min in S. typhimurium) product was found to be a diffusible protein which was a positive regulator of katG (HPI; $88 \mathrm{~min})$, and ahp (alkylhydroperoxidase; $13.8 \mathrm{~min}$ ) in 5 . typhimurium and possibly sodA (superoxide dismutase; $89.5 \mathrm{~min}$ ) and $g s h$ (glutathione reductase; 13.8 
min) (Christman et al., 1985). The induction of HPI protein was shown to occur at the transcriptional level (Morgan et al., 1986) with oxyR1 mutants containing 50x the normal level of HPI mRNA.

Morgan et al. (1986) found that the proteins induced by $\mathrm{H}_{2} \mathrm{O}_{2}$ are not the same proteins affected by an aerobic-anaerobic shift. None of the oxyR regulated proteins, including HPI were inducible by $\mathrm{O}_{2}$. $\mathrm{HPI}-\mathrm{A}$ and $\mathrm{HPI}-\mathrm{B}$ were in fact found to be more abundant during anoxic growth. Some interesting features regarding the induction of the oxyR regulon were observed by Christman et al. (1985). $\mathrm{H}_{2} \mathrm{O}_{2}$ induced the synthesis of adenylated nucleotides previously shown to be induced by oxidative stress, heat shock, and amino acid deficiency. The main adenylated nucleotide shown to accumulate was AppPpA (Bochner et al., 1984; Lee et al., 1983). These dinucleotides have been termed alarmones (Stephens et al., 1975) and are believed to lead to the redirection of metabolism to cope with cell stress. Furthermore, the alkylhydroperoxidase overexpressed in oxyR1 was a heat shock protein that required oxyR in addition to the positive heat shock regulator, $h t p R$ for heat shock induction in S. typhimurium but not in $E$. coli.

The mechanism of induction of the oxyR regulon is not well understood but a number of ideas have been proposed. The oxyR protein may be analagous to htpR of the heat shock response which acts as the sigma subunit of RNA polymerase allowing recognition of the heat shock promoters of the genes encoding 17 heat shock proteins (Gottesman, 1984). It has been suggested that abnormally folded proteins may induce the heat shock response (Goff and Goldberg, 1985). Another analogous protein is the ada protein, responsible for the induction of ONA repair by alkylating agents. The methylation of this protein allows it to activate 
a number of genes (Teo et al.,9986). Morgan et al. (1986) have suggested that the direct oxidation of a regulatory protein by $\mathrm{H}_{2} \mathrm{O}_{2}$ may be the inducer of the oxidative stress response or adenylated nucleotides may serve as a primary signal.

\subsection{The Function of catalase in $E_{0}$ coli}

Catalase is known to break down $\mathrm{H}_{2} \mathrm{O}_{2}$, but the ability of catalase deficient mutants of $E$. coli to grow normally (Loewen, 1984) has obscured the functional significance of catalase. However, the presence of two independently regulated catalases in $E$. coli suggests that they serve an important function. Some characteristics relating to the function of bacterial catalases are presented.

Barbado et al. (1983) isolated E. coli mutants sensitive to $\mathrm{H}_{2} \mathrm{O}_{2}$ and found they were deficient in catalase and/or peroxidase. E. coli catalase mutants are always sensitive to $\mathrm{H}_{2} \mathrm{O}_{2}$ (Loewen, 1984; Meir and Yagil. 1984). $\mathrm{O}_{2}^{-}$sensitive mutants of Bacillus coagulans have lower catalase levels (Vassilyadi and Archibald, 1985).

Transposon Tn10 mutants of $S$. typhimurium unable to survive in macrophage were isolated and found to be less virulent in vivo as well. Two of these isolates were oxyR mutants, but none of them were catalase deficient. A transposon Tn10 insertion removing HPII activity did not affect the virulence of the strain (Fields et al., 1986).

Catalase is important in the protection of Lactobacillus plantarum from the toxic accumulation of $\mathrm{H}_{2} \mathrm{O}_{2}$ during stationary phase (Kono and Fridovich, 1983a). Catalase is also needed for yeast to sporulate. During sporulation, catalase levels increase, (Ota, 1986) and mutants deficient in catalase are unable to sporulate inferring a role for 
catalase in the protection of enzymes required for sporulation cota, 1986).

\subsection{Loci Affecting Catalase Synthes is}

Four loci affecting catalase levels in $E$. coli have been identified and mapped. Mutants of two of the loci, katE and katF, were deficient in HPII and had very low catalase levels when tested on agar plates. Three factor cotransductional crosses mapped katE at $37.8 \mathrm{~min}$ in the order pps-phes-pfkB-katE-xthA (Loewen, 1984) and katF at $59 \mathrm{~min}$ in the order srl-muts-katf-iap-cysthpyrG (Loewen and Triggs, 1984) on the E. coli chromosome. Mutants of the katG locus were deficient in HPI catalase but appeared to have relatively normal catalase levels when tested on agar plates. HPI mutants could only be identified when the HPII catalase was already absent. The katG locus was mapped by three factor cotransductional crosses among several markers, $p f k A-m e t B-k a t G-$ ppc-argHtmetA at $89.2 \mathrm{~min}$ on the E. coli chromosome (Loewen et al., 1985b). Christman et al., (4985), identified a fourth locus, oxyR, which is a positive regulator of $k a t G$, and mapped it to $88 \mathrm{~min}$ on the $s$. typh imur ium chromosome.

Three catalase loci katA-D have been identified in S. typhimurium but of these, only katC was mapped by $P 1$ transduction to near the proAB region at $7 \mathrm{~min}$ (Levine, 1977). None of these loci have been identified in E. coli.

\subsection{Catalase and Near-UV (NUV) Light}

Near-UV (NUV) light (300-400 nm) is one of many forms of ionizing radiation that exhibits oxygen dependent killing (McCormick et al., 
1976). The passage of radiation through water generates $\mathrm{OH}$, hydrogen atoms, and hydrated electrons. The hydrogen atoms and hydrated electrons produce $\mathrm{O}_{2}^{-}$, the $\mathrm{OH}^{-}$form $\mathrm{H}_{2} \mathrm{O}_{2}$, and these species, $\mathrm{O}_{2}^{-}, \mathrm{OH}$, and $\mathrm{H}_{2} \mathrm{O}_{2}$, fur ther react to form more of the secondary product, $\mathrm{OH}$. (Fridovich, 1978)

Evidence has accumulated implicating $\mathrm{H}_{2} \mathrm{O}_{2}$ as an important mediator of NUV killing. The lethal photooxidation product which resulted from the NUV exposure of tryptophan was characterized and found to be $\mathrm{H}_{2} \mathrm{O}_{2}$ (McCormick et al., 1976). Sammartano et al. (1986) showed that cells could be protected from the toxic effects of NUV if catalase was incorporated in the media. Mutants of the repair enzyme exonuclease 111 were sensitive to both $\mathrm{H}_{2} \mathrm{O}_{2}$ and NUV suggesting that $\mathrm{H}_{2} \mathrm{O}_{2}$ was playing an important role in NUV mutagenes is (Sammartano and Tuveson, 1984). Pretreatment of E. coli and S. typhimurium with $\mathrm{H}_{2} \mathrm{O}_{2}$ (an inducer of $\mathrm{HPI}$ catalase) induced resistance to NUV (Sammartano et al., 1986). Far-UV light did not $k i l l$ in an oxygen dependent fashion (Sammartano and Tuveson, 1984).

E. coli mutants hypersensitive to NUV were isolated (Tuveson, 1981) and later identified as katF (HP|1) mutants (Sammartano et al., 1986). This same group examined katE (HPII) and katG (HPI) mutants and found that these mutants were not NUV sensitive, contradicting the implicated role of catalase in NUV protection. However pretreatment of E. coli cells with $\mathrm{H}_{2} \mathrm{O}_{2}$ (inducing all oxyR regulated proteins including HPI catalase) did increase NUV resistance (Sammartano et al., 1986; Tyrrell, 1985).

Kramer and Ames (1987) have confirmed the involvement of the oxyR regulon in NUV resistance but they have demonstrated that HPI catalase is 
not a mediator of this resistance. While katG mutants were not NUV sensitive, ahp (alkylhydroperoxidase) and gsh (glutathione reductase) mutants were NUV sensitive. NUV was able to induce $\mathrm{H}_{2} \mathrm{O}_{2}$ sensitivity, because the absorption of NUV light by catalase, caused its inactivation. High levels of catalase actually acted as a sensitizer of cells to NUV. Eisenstark and Perrot (1987) have confirmed this using the catalase mutant UM228 and UM228 carrying a katG-containing multicopy plasmid (pBT22). Although the cells carrying the plasmid were slightly more resistant to $\mathrm{H}_{2} \mathrm{O}_{2}$, they had increased NUV sensitivity. OxyR1 mutants which overproduce HPI also show increased sensitivity to NUV. The role of catalase as a sensitizer is supported by the fact that hemA mutants that are defective in the synthesis of $\delta$-aminolevulinic acid, a precursor to porphyrin synthesis, are more resistant to NUV light (Tuveson and Sammartano, 1986).

\subsection{Catalase and Spontaneous Mutagenes is}

The identification of DNA as one of the targets of toxic oxygen species was further supported by the knowledge that the rate of spontaneous mutagenesis in $S$. typhimurium is influenced by the oxyR regulon. Cells with an oxyR deletion have higher rates of spontaneous mutation than their wild type parent, while cells carrying the oxyR1 mutation, which results in the overproduction of oxidative defense products have lower rates of spontaneous mutation (sies et al, in press). The largest increase in mutation rates of oxyR deletion involves $T: A$ to A:T transversions, the predominant oxygen related mutation (Levin et al., 1982).

Higher mutation rates have been observed during the aerobic growth 
of cells lacking both the manganese and iron superoxide dismutases (Farr

et al., 1986), Sies et al. (in press) introduced various multicopy

plasmids bearing oxidative defense products into oxyR mutants and

observed the effect on spontaneous mutation rates. Plasmids bearing sodA

(superoxide dismutase) lowered the mutation rates slightly and katG (HPI)

and ahp (alkylhydroperoxidase) bearing plasmids decreased the

spontaneous mutation rate to near that of the wild type while extra-

cellular addition of catalase or superoxide dismutase did not lower the

mutation rates. Sies et al. (in press) suggest that these results

confirm the role of reactive oxygen species from respiration in

mutagenesis.

\subsection{Catalase Gene and Protein Sequences}

The DNA sequences from rat liver catalase ([CDNA]; Osumi et al., 1984;

Furuta et al., 1986), human catalase ([CDNA]; Quan et al., 1986; Bell et al., 1986) and yeast T-catalase (Hartig and Ruis, 1986) have been

determined and the amino acid sequences predicted. A comparison of these sequences to the chemically determined amino acid sequences of bovine liver catalase (BLC) and bovine erythrocyte catalase (Schroeder et al., 1982a; 1982b) revealed a 90\% homology between BLC and rat liver or human catalase, and a 40.7\% homology between BLC and the most conserved portion of yeast catalase $T$. The three dimensional structures of Penicillium vitale catalase (Vainshtein et al, 1986) and BLC (Fita and Rossmann, 1985b) were compared (Melik-Adamyan et al., 1986) and found to be highly conserved at the tertiary and secondary levels. The $x$-ray crystal structures of BLC identified the amino acids important in catalysis or heme binding (Fita and Rossmann, 1985b) and the conservation of these 


\section{same amino acids in other catalases substantiated this.}

The $x$-ray structure and amino acid sequence of BLC were in complete agreement (Fita and Rossmann, 1985b). Although the original sequence of BLC (Schroeder et al., 1982a) was only 506 amino acids in length, predicted sequences from other sources are 526 amino acids in length (Furuta et al., 1986). BLC appeared to be in a processed form when it was isolated. The 3-D structure of catalase has been described as a N-terminal arm followed by a $\beta$-barrel and then an $\alpha$-helical domain (Fita and Rossmann, 1985b), The B-barrel, made up of eight antiparallel $\beta$-pleated sheets, contains the heme binding residues and consequently shows the highest levels of conservation. As the sequence proceeds toward the carboxyl terminus, the proteins diverge into what has been identified as a high affinity $N A D(P) H$ binding region in human catalase (Kirkman et al,, 1984) and BLC (Fita and Rossmann, 1985a) and a flavodoxin binding domain in $P$. vitale catalase (Vainshtein et al., 1986). In yeast $T$ catalase, although the carboxyl terminus is divergent, no particular function has been assigned to it (Hartig and Ruis 1986). The functional significance of the $N A D(P) H$ and flavodoxin binding domains remains unclear since they do not appear essential to catalase activity. The amino acids in the B-barrel domain which are essential to catalysis include His-74, Ser-113, and Asn-147. These residues are conserved in all of the aforementioned catalases. There are many residues with heme contacts; notably, the phenol group of Tyr-347 occupies the 5th ligand position of the $\mathrm{Fe}$ in protoporphyrin $1 \mathrm{X}$. Tyr-357 is conserved in yeast $T$ catalase and only $5 / 25$ heme contacts shorter than $0.4 \mathrm{~nm}$ in BLC are replaced in yeast catalase $T$ (Hartig and Ruis, 1986). His-74 has been identified as the probable active site since it is the site of 
action of aminotriazole in BLC (Margoliash et al., 1960). AT is active on compound 1 of the catalase reaction and thus $\mathrm{H}_{2} \mathrm{O}_{2}$ is required to form it. The structure of AT is shown below.

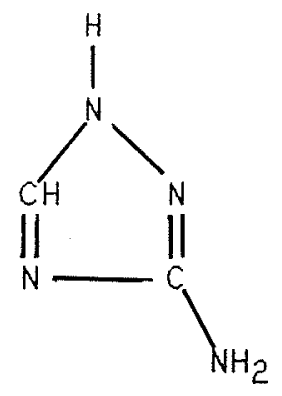

(Halliwell and Gutteridge, 1985)

The heme groups in $P$. vitale and BLC are buried deep within the protein forcing substrates to enter a polar channel which becomes hydrophobic as it approaches the heme group (Murthy et al., 1981).

\subsection{E. coli Control Sequences}

Gene expression in E. coli is controlled by the DNA sequence and a complex network of proteins capable of interacting with nucleic acids. A) though there are many types of regulation in $E$. coli only a few elements have been well characterized. The recent accumulation of DNA sequences has aided in the identification of consensus sequences or structural elements typical of E. coli regulatory elements. The sequences have also been useful in the analysis of codon usage as a mechanism of regulation of gene expression.

The promoters of RNA transcription are very important in the regulation of gene expression. In a recent study by Harley and Reynolds (1987), 263 promoter regions were aligned and the promoter sequences were compared. They found the controlling elements upstream of the transcriptional start site, ( -35 and -10 regions) to have the following 
consensus sequence:

$$
\text { c.a..t....TTGACA..t..........gg TATAATg }
$$$$
-35-10
$$

The hexameric sequences at -35 and -10 , and the 17 bp distance between them were highly conserved. A few nucleotides occurring with frequencies greater than random variation are also indicated. This group found a correlation between promoter homology and strength in many instances, and a poor consensus to the -35 sequence in positively regulated genes. Initiation of the transcript commonly occurred 6-8 bp downstream from the $3^{\prime}$ end of the -10 region at a purine residue. The purine was commonly an A residue which has been weakly associated with the sequence CAT at the startsite. The promoter may also be capable of binding positive or negative regulatory proteins that can further modify gene expression. Although termination of transcription has not been as well characterized as promotion, certain features important in termination have been identified. All rho independent, or simple terminators contain a region of hyphenated dyad symmetry followed by a series of $U$ residues. More complex terminators (Platt and Bear, 1983) have been characterized and found to show extreme variation. It is thought however that many rho dependent terminators still show a region of hyphenated dyad symmetry rich in $G / C$ residues, but this was not followed by the poly $U$ sequence (Rosenberg and Court, 1979).

Translational control is not as clearly understood. Proteins can initiate with a methionine, valine, or leucine codon, indicating the need for other factors to control recognition. In most promoters, this appears to be a sequence called the shine-Dalgarno sequence (AGGAGG) which is complementary to the $3^{\prime}$-end of the $16 \mathrm{~s}$ rRNA. However, this. 
sequence in not always present (Ganoza et al., 1987).

The codon choice of organisms is representative of the availability of tRNA molecules in the cell (Ikemura and Ozeki, 1982). The codon choices also vary depending of the anticodon modifications which occur in the cell. Organisms have been shown to bias the codon usage in highly expressed genes to achieve optimum codon-anticodon interaction energies that are neither too strong nor too weak. Thus in highly expressed genes the codon usage will be clearly biased to avoid the usage of low abundance tRNAs and codon-anticodon interactions which are energetically unfavourable (Grosjean and Fiers, 1982). The codon usage acts as a form of translational control, modulating the expression of genes at the level of translation. Codon context has also been implicated as a factor influencing gene expression (Shpaer, 1986).

\subsection{Characterization of a Plasmid Encoding the HPI Catalase}

The Carbon and Clarke plasmid bank (Carbon and Clarke, 1976) was screened for potential catalase carrying plasmids by dropping $30 \% \mathrm{H}_{2} \mathrm{O}_{2}$ on the edge of the colonies and looking for above average oxygen evolution. of 88 colonies that appeared to have above average oxygen evolution, only one, pLC36-19, had higher catalase when assayed in the oxygraph. Characterization of pLC36-19 revealed it to be a $25.5 \mathrm{~kb}$ plasmid made up of a $19.1 \mathrm{~kb} E$. coli genomic DNA insert and a $6.4 \mathrm{~kb}$ ColEl vector. The plasmid complemented catalase deficient mutants and produced the HPI protein in these mutant cells. Minicell preparations of pLC36-19 containing cells produced an 84000 dalton polypeptide, the same size as the HPI subunit (Loewen et al., 1983). The characterization of the HPI encoding gene on this plasmid is the subject of the study presented in this thesis. 
MATERIALS AND METHODS 


\subsection{MATERIALS AND METHODS}

\section{1 Bacterial Strains and Plasmids}

All bacterial strains used in this study were derivatives of Escherichia coli K-12. Table 1 lists the strains with their genotype and their source or method of construction. Stationary phase cultures of new strains were stored in $50 \%$ glycerol at $-20^{\circ} \mathrm{C}$ and in $8 \%$ DMSO at $-60^{\circ} \mathrm{C}$. The plasmids used and/or constructed during this study are described in Table 2.

\subsection{Standard Bacterial Growth Conditions, Media, and Solutions}

\subsubsection{Bacterial Growth Conditions}

Unless otherwise stated, broth cultures of $E$. coli were grown with aeration at $37^{\circ} \mathrm{C}$. Precultures were prepared by inoculating $10 \mathrm{~mL}$ of LB broth with a loop full of the glycerol stock culture and incubating overnight. Log phase cultures were prepared by subculturing $0.1 \mathrm{~mL}$ of the preculture into a fresh tube of $L B$ broth and shaking for 2-4 h. Cell densities of liquid cultures were measured using a KlettSummerson colorimeter equipped with a blue filter.

Agar plates were usually inverted and incubated one to two days at $37^{\circ} \mathrm{C}$ in a Fisher I sotemp Incubator.

\subsubsection{Media and Commonly Used Solutions}

A. LB Medium (Miller, 1972) per 1 iter:

$10.0 \mathrm{~g}$ tryptone (Difco)

$5.0 \mathrm{~g}$ yeast extract (Difco)

$5.0 \mathrm{~g} \mathrm{NaCl}$

for agar plates: add $10.0 \mathrm{~g}$ agar (Difco) 
Table 1. List of E. colistrains

\begin{tabular}{|c|c|c|}
\hline Strain & Genotype & Reference or Source \\
\hline$J A 200$ & $\mathrm{~F}^{+}$reca trp thr leu & Clarke \& Carbon(1976) \\
\hline HB101 & pro leu rpsl hsdM hsdR endl recA lacy & $\begin{array}{l}\text { Boyer \& Roulland- } \\
\text { Dussoix(1969) }\end{array}$ \\
\hline JM101 & supe thi $(l a C$ proAB)/F'traD 36 proAB & $\begin{array}{c}\text { Yanisch-Perron et al. } \\
\text { (1985) }\end{array}$ \\
\hline MP180 & thi-1 HfrH & Pearson (1972) \\
\hline CSR603 & 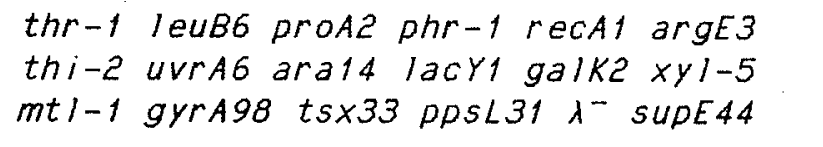 & Sancar et al. (1979) \\
\hline RR 1 & pro leu rosl hsdM hsdR endl lacy & Bolivar et al.(1977) \\
\hline NK5012 & sull' thr leu lacyl tonA & H. Goldie \\
\hline $\mathrm{CSH} 7$ & $\mathrm{~F}^{-}$lacy rosL thi-1 & C.S.H.C.a \\
\hline CSH57a & $\begin{array}{l}\mathrm{F}^{-} \text {leuB6 proC83 purE } 42 \text { trpE28 his-208 } \\
\text { argG77 ilvA681 metA160 thi-1 ara-14 } \\
\text { lacyl galK2 xyl-5 mtI-1 aZi-6 rpsL109 } \\
\text { tonA23 tsx-67 supE } 44 \text { malA38 xthA }\end{array}$ & C.S.H.C.a \\
\hline JM96 & $\begin{array}{l}\text { cyst thr leu trp his argh thi lac } \\
\text { xyl gal mal rpsL }\end{array}$ & $\begin{array}{l}\text { Jones-Mortimer } \\
(1968,1973)\end{array}$ \\
\hline JF627 & $\begin{array}{l}\text { thi-1 pyrE60 pyrG edd relA1 arge3 } \\
\text { his-4 proA2 thr-1 leu-6 mtl-1 xyl-5 } \\
\text { ara-14 galKe lacyl rpsL31 supE } 44\end{array}$ & Friesen et al.(1976) \\
\hline 4206 & Hfr thi recA relA deoB & $C . G . S . C . b$ \\
\hline 4913 & $\begin{array}{l}\text { Hfr phes5 rela1 tonA22 } \mathrm{T}^{\mathrm{R}} \text { pit10 } \\
\text { spoT1 }\end{array}$ & C.G.S.C.D \\
\hline 5128 & Hfr(R4) deoA upp udp metB arge relA & $C \cdot G \cdot S \cdot C \cdot b$ \\
\hline 5236 & $\begin{array}{l}\text { aceB6 ppc-2 glc-1 thi-1 relA1 } \\
\text { lacZ43 } \lambda^{-} \text {spoT1 }\end{array}$ & $C \cdot G \cdot S \cdot C \cdot b$ \\
\hline 6374 & $\begin{array}{l}\mathrm{F}^{-} \text {hiss glyA rela argh thi lacyorz } \\
\text { xyl mtl rosL supe }\end{array}$ & C.G.S.C.b \\
\hline PA309 & trp his argh leu rpsL & Jones-Mortimer \\
\hline
\end{tabular}




\begin{tabular}{|c|c|c|}
\hline UM1 & as CSH7 but katE1 katG14 & Nitrosoguanidine \\
\hline UM2 & as CSH57a but katE2 katG15 & Nitrosoguanidine \\
\hline UM5 & as UM1 but his & Nitrosoguanidine \\
\hline UM53 & as UM2 but recA & $\begin{array}{c}4206 \times \text { UM5O } \\
\text { thyA } A^{+} \text {recA }\end{array}$ \\
\hline UM56-64 & as CSH57a but katF3 katG16 & Nitrosoguanidine \\
\hline UM68 & as HB101 but kat-26 & Nitrosoguanidine \\
\hline UM69 & as HB101 but kat-27 & Nitrosoguanidine \\
\hline UM120 & as MP 180 but katE: :Tn 10 & MP180 $\times \lambda 561 \longrightarrow T^{R}$ \\
\hline UM122 & as MP 180 but katF: :Tn 10 & MP180 $\times \lambda 561 \longrightarrow \mathrm{TC}^{R}$ \\
\hline UM123 & as 0 M6 9 but $k a t-18$ & Nitrosoguanidine \\
\hline UM178 & as UM5 but lact $^{+} k a t 6^{+}$ & $\mathrm{CSH} 64 \times \mathrm{UM} 5 \longrightarrow \mathrm{LaC}^{+}$ \\
\hline UM196 & as UM178 but kat617: :Tn 10 & $\mathrm{UM} 178 \times \lambda 561 \longrightarrow \mathrm{TC}^{\mathrm{R}}$ \\
\hline UM197 & as CSH57A but kat617: $\operatorname{Tn} 10$ & P1 (UM196) $\times C$ CSH57a $\rightarrow T^{R}$ \\
\hline UM202 & as MP180 but katG17: :Tn 10 & P1 $\left(\right.$ UM196) $\times M P 180 \rightarrow T C^{R}$ \\
\hline UM228 & as HB101 but kat-19 & Nitrosoguanidine \\
\hline UM229 & as HB101 but kat-28 & Nitrosoguanidine \\
\hline UM230 & as HB101 but kat-29 & Nitrosoguanidine \\
\hline UM262 & as RR1 but recA katg17: Tn 10 & $\begin{aligned} 4206 & \times \text { UM263 } \\
& \text { thys }{ }^{+} \text {recA }\end{aligned}$ \\
\hline UM263 & as RR1 but thyA katG17: Tn 10 & $\begin{array}{l}\mathrm{P} 1(\mathrm{UM} 196) \times \mathrm{RR} \longrightarrow \mathrm{Tc}^{\mathrm{R}} \\
\text { Tr imethopr im } \longrightarrow \text { thyA }\end{array}$ \\
\hline
\end{tabular}

a Cold Spring Harbour Collection

b Coli Genetic Stock Center, B. Bachmann, Curator 
Table 2. Bacterial plasmids

\begin{tabular}{|c|c|c|}
\hline Plasmid & Characteristics & Reference of Source \\
\hline PAT153 & $A p^{R} T c^{R}$ & Twigg \& Sherratt(1980) \\
\hline DBR322 & $A D^{R} T C^{R}$ & Sutcliffe(1978) \\
\hline pkK232-8 & $A P^{R} \mathrm{Cm}^{S}$ & Brosius (1984) \\
\hline COIEA & $\operatorname{cole} 1^{R}$ & Hershfield et al. (1974) \\
\hline pLC36-19 & $\operatorname{colE} 1^{R} \mathrm{katg}^{+}$ & Clarke \& Carbon(1976) \\
\hline DA30 & PLC36-19::Tn5; $\mathrm{km}^{\mathrm{R}}$ & $\lambda N K 467 \times$ JA2OO/DLC36-19 \\
\hline DE6 & PLC36-19::Tn5; $\mathrm{km}^{\mathrm{R}}$ & $\lambda N K 467 \times J A 200 / D L C 36-19$ \\
\hline pC 1 & pLC36-19::Tn5; $\mathrm{km}^{\mathrm{R}}$ & $\lambda N K 467 \times J A 200 / D L C 36-19$ \\
\hline pD31 & $\mathrm{pLC} 36-19:: \operatorname{Tn} 5 ; \mathrm{km}^{\mathrm{R}}$ & $\lambda N K 467 \times J A 200 /$ DLC36-19 \\
\hline PBT1 & $\mathrm{Km}^{\mathrm{R}}$ katG2O & Hindll deletion of $\mathrm{DC} 1$ \\
\hline pBT2 & $\mathrm{Km}^{\mathrm{R}} \mathrm{katG}^{+}$ & Hindlll deletion of $\mathrm{DCl}$ \\
\hline pBT5 & $A P^{R} T_{C}^{S}$ katG21 & $p L C 36-19 \cdot S p h 1+P A T 153 \cdot S p h 1$ \\
\hline pBT22 & $A p^{R} \mathrm{Tc}^{S} \mathrm{katG}^{+}$ & 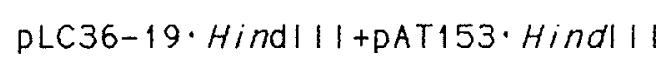 \\
\hline pBT54 & $A P^{R} T C^{S} k a t G^{+}$ & 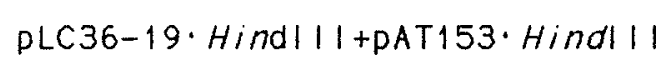 \\
\hline pBT24 & $A p^{R} T C^{S}$ katG22 & ECoR1 deletion from pBT22 \\
\hline pBT25 & Ap ${ }^{R} T_{c} S$ katG25 & BAL31 deletion from PBT22 \\
\hline pBT28 & $\mathrm{AD}^{\mathrm{R}} \mathrm{TC}^{\mathrm{S}}$ katG & BAL31 deletion from $\mathrm{DBT} 22$ \\
\hline pBT29 & $A p^{R} T C^{S}$ katG23 & BAL31 deletion from $\mathrm{PBT} 22$ \\
\hline pBT30 & $A D^{R} T C^{S} k a t G 24$ & BAL31 deletion from pBT22 \\
\hline pGprm1 & $A p^{R} \mathrm{Cm}^{R}$ & pBT22·Bg/I+pKK232-8·BamHI \\
\hline pMSKatG14 & $A P^{R} T C^{S}$ katG14 & as pBT22 but katG14 \\
\hline pMSKatG15 & $A D^{R} T C^{S}$ katG15 & as pBT22 but kato15 \\
\hline
\end{tabular}




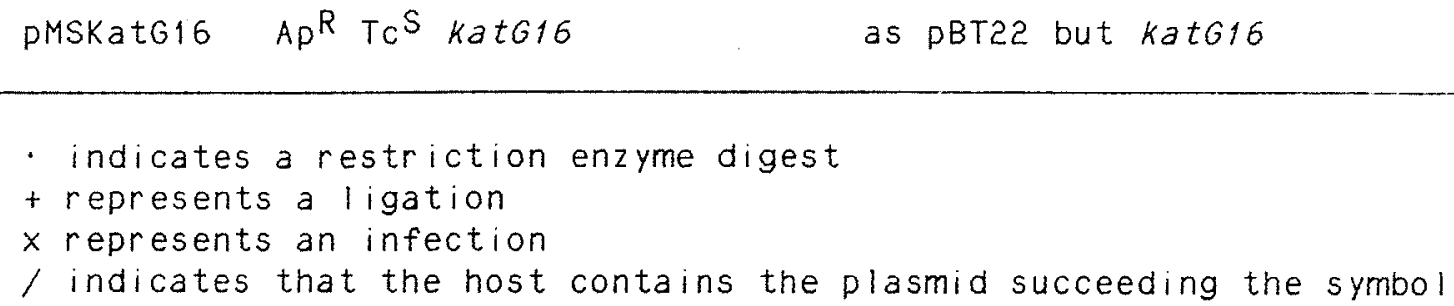


for LB top agar: add $8.0 \mathrm{~g}$ agar

for $R$ top agar: add $8.0 \mathrm{~g}$ agar; The agar was supplemented

after autoclaving with $6.0 \mathrm{mM}$ glucose and $2.0 \mathrm{mM} \mathrm{CaCl} 2$.

B. M9 Medium (Miller, 4972)

per liter:

$0.5 \mathrm{~g} \mathrm{NaCl}$

$6.0 \mathrm{~g} \quad \mathrm{Na}_{2} \mathrm{HPO}_{4}$

$1.0 \mathrm{~g} \mathrm{NH} \mathrm{NH}_{4} \mathrm{Cl}$

$3.0 \mathrm{~g} \mathrm{KH}_{2} \mathrm{PO}_{4}$

for agar plates: add $10.0 \mathrm{~g}$ agar

The medium was supplemented after autoclaving with $3 \mu M \vee$ itamin $\mathrm{B} 1,1.0 \mathrm{mM} \mathrm{MgSO} 4$, and $1.0 \mathrm{~mL}$ of trace elements.

Trace Elements

per liter:

$$
\begin{array}{ll}
2.5 \mathrm{~g} & \mathrm{FeSO}_{4} \cdot \mathrm{H}_{2} \mathrm{O} \\
2.9 \mathrm{~g} & \mathrm{H}_{3} \mathrm{BO}_{3} \\
1.2 \mathrm{~g} & \mathrm{COSO}_{4} \cdot 7 \mathrm{H}_{2} \mathrm{O} \\
0.1 \mathrm{~g} & \mathrm{CuSO}_{4} \cdot 5 \mathrm{H}_{2} \mathrm{O} \\
0.09 \mathrm{~g} & \mathrm{MnCl}_{2} \cdot 4 \mathrm{H}_{2} \mathrm{O} \\
2.5 \mathrm{~g} & \mathrm{Na}_{2} \mathrm{MOO}_{4} \cdot 2 \mathrm{H}_{2} \mathrm{O} \\
2.1 \mathrm{~g} & \mathrm{ZnSO}_{4} \cdot 7 \mathrm{H}_{2} \mathrm{O} \\
5.0 \mathrm{~mL} & \text { conc. } \mathrm{H}_{2} \mathrm{SO}_{4}
\end{array}
$$

Other supplements, including $16.7 \mathrm{mM}$ glucose, $90.8 \mathrm{mM}$ pyruvate, $0.16 \mathrm{mM}$ amino acids, $94 \mu \mathrm{M}$ adenosine, $0.22 \mathrm{mM}$ uracil, and

$0.1 \mathrm{mM}$ cytidine were added as required.

C. TB or $\lambda$ Medium (Silhavy et al., 1984) per liter:

$$
\begin{array}{rl}
5.0 \mathrm{~g} & \mathrm{NaCl} \\
10.0 \mathrm{~g} & \text { tryptone }
\end{array}
$$

TBYM broth was prepared by supplementing TB broth with $5.8 \mathrm{mM}$ maltose and $0.01 \%(w / v)$ yeast extract.

for agar plates: add $10.0 \mathrm{~g}$ agar

for top agar: add $7.0 \mathrm{~g}$ agar

D. F-top agar (Miller, 1972)

per liter:

$8.0 \mathrm{~g} \mathrm{NaCl}$

$8.0 \mathrm{~g}$ agar

E. 2XYT Medium (Miller, 1972)

per liter:

$5.0 \mathrm{~g} \mathrm{NaCl}$

$16.0 \mathrm{~g}$ tryptone

$10.0 \mathrm{~g}$ yeast extract 
This was adjusted to $\mathrm{pH} 7$ before autoclaving.

F. K Medium (Rupp et al., 1971)

M9 Medium was supplemented before autoclaving with $1 \%$ casamino

acids and after autoclaving with $0.3 \mu \mathrm{M}$ vitamin $B 1$ and

$16.6 \mathrm{mM} \mathrm{glucose}$.

G. Hershey's Salts (Worcel and Burgi, 1974)

per liter:
$5.4 \mathrm{~g} \quad \mathrm{NaCl}$
$3.0 \mathrm{~g} \quad \mathrm{KCl}$
$1.1 \mathrm{~g} \quad \mathrm{NH}_{4} \mathrm{Cl}$
$0.045 \mathrm{~g} \mathrm{CaCl}_{2} .2 \mathrm{H}_{2} \mathrm{O}$
$0.02 \mathrm{~g} \mathrm{MgCl}_{2} \cdot 6 \mathrm{H}_{2} \mathrm{O}$
$0.02 \mathrm{mg} \mathrm{FeCl} 3.6 \mathrm{H}_{2} \mathrm{O}$
$0.087 \mathrm{~g} \quad \mathrm{KH}_{2} \mathrm{PO}_{4}$
$0.028 \mathrm{~g} \mathrm{Na} \mathrm{NO}_{4}$
$12.1 \mathrm{~g}$ Trizma base
$\mathrm{HCl}$ to $\mathrm{pH} 7.4$

H. Hershey's Medium (Worcel and Burgi, 1974)

Hershey's Salts were supplemented after autoclaving with

$3 \mathrm{mM}$ vitamin B1, $22.2 \mathrm{mM}$ glucose and $0.16 \mathrm{mM}$ amino acids

as required by the strains.

1. Maloy Medium (Maloy and Nunn, 1981)

per liter:

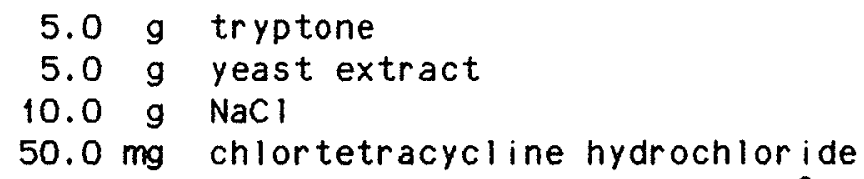

After autoclaving, the medium was cooled to $45^{\circ} \mathrm{C}$, then $20 \mathrm{~mL}$ of sterile $3.5 \mathrm{M} \mathrm{NaH}_{2} \mathrm{PO}_{4} \cdot \mathrm{H}_{2} \mathrm{O}, 6.0 \mathrm{~mL}$ of sterile $10 \mathrm{mM}$ fusaric acid, and $5.0 \mathrm{~mL}$ of sterile $20 \mathrm{mM} \mathrm{ZnCl}_{2}$ were added.

The following antibiotics ampicillin $(100 \mu \mathrm{g} / \mathrm{mL})$, tetracycline $(15 \mu \mathrm{g} / \mathrm{mL})$, streptomycin $(80 \mu \mathrm{g} / \mathrm{mL})$, and kanamycin $(25 \mu \mathrm{g} / \mathrm{mL})$ were added as required to the above media. Antibiotic containing agar plates are represented by adding the first letter of the antibiotic name onto the media name, for example, LBA are ampicillin containing LB plates.

J. SM Buffer (Miller, 1972)

$0.05 \mathrm{M} \mathrm{Tris-HCL} \mathrm{pH} 7.5$

$0.01 \mathrm{M} \mathrm{MgSO} 4$

$0.1 \%$ gelatin

K. Phenol

Redistilled phenol was buffered with

$0.1 \mathrm{M} \mathrm{NaCl}$

$0.1 \mathrm{M} \mathrm{Tris}-\mathrm{HCl} \mathrm{pH} 7.6$

$1.0 \mathrm{mM}$ EDTA

L. TE (Maniatis et al., 1982)

$10.0 \mathrm{mH} \mathrm{Tris-HCl} \mathrm{pH} 8.0$ 


$$
1.0 \mathrm{mM} \text { EDTA DH } 8.0
$$

M. TEN 250

TE containing $250 \mathrm{mM} \mathrm{NaCl}$

N. Ethanol

Unless otherwise stated all ethanol was $95 \%$

\subsection{Measurement of DNA and Protein Concentrations}

DNA concentrations were estimated by electrophoresing a specific volume of a sample of unknown concentration beside a sample containing a known quantity of DNA. After staining the gel in EtBr, the two samples were photographed under an indirect uV light source. The concentration was then estimated on a comparative basis. DNA concentrations were also determined spectrophotometrically by taking the $A_{260}$ of the sample. Since $1 A_{260}$ unit of bacterial DNA was known to contain approximately $50 \mu \mathrm{g}$ of DNA, the quantity of DNA was calculated on this basis. The ratio of the $A_{260}$ to the $A_{2} 80$ was then used as an indicator of purity, pure DNA having an $A_{260} / A_{280}$ ratio of 1.8 (Maniatis et al., 1982).

Protein concentrations were estimated spectrophotometrically by taking the ratio of the $A_{280}$ to the $A_{260}$. This ratio was compared to a table of values for known protein concentrations to get the value $F$, where: $\quad F=2.303 \times$ per cent protein

$$
\beta_{280} \quad 100
$$

$F$ was then substituted into the following formula to give the protein concentration in $\mathrm{mg} / \mathrm{mL}$ (Layne, 1957).

$$
\begin{aligned}
& {\left[\text { protein] }=F \times 1 / d \times A_{280}\right.} \\
& \quad \text { where } d=\text { cuvette width in } \mathrm{cm}
\end{aligned}
$$




\subsection{Isolation of Catalase Mutants by Nitrosoguanidine (NG) Mutagenesis}

HB101 was grown to early exponential phase $\left(2 \times 10^{8} \mathrm{cel} / \mathrm{s} / \mathrm{mL}\right)$ in LB broth and the cells were collected by centrifugation at $12000 \times \mathrm{g}$ for $5 \mathrm{~min}$. The pellet was resuspended in $10 \mathrm{~mL}$ of $1 \mathrm{M}$ sodium citrate $\mathrm{pH} 5.5$ and $0.5 \mathrm{~mL}$ of $\mathrm{NG}(1 \mathrm{mg} / \mathrm{mL}$ prepared in citrate buffer) was added. This was incubated with aeration for $30 \mathrm{~min}$ at $37^{\circ} \mathrm{C}$. The cells were pelleted by centrifugation at $12000 \times \mathrm{g}$ for $10 \mathrm{~min}$ and after washing the pellet once in $M 9$ medium, it was resuspended in $10 \mathrm{~mL}$ of $M 9$ medium supplemented with glucose, proline, and leucine. The culture was shaken overnight at $37^{\circ} \mathrm{C}$, then serially diluted in SM and plated on LBS plates. The dilution which gave approximately 200 colonies per plate was used to spread 11 plates, which after incubation overnight were screened for catalase mutants by the colony $\mathrm{H}_{2} \mathrm{O}_{2}$ drop test described in section 3.7.1. Colonies which evolved little or no oxygen were quickly picked and transferred to another LBS plate for rescreening.

\subsection{Transposon Mutagenes is}

\subsubsection{Preparation of Transposon Carrying Phage Lysates}

The E. coli strain NK5012 was grown to mid-log phase in TBYM broth. A phage lysate of $\lambda 561$ (b221 C1857 rex: Tn 10 Oam29 Pam80) (Foster et al., 1981) or גNK467 (b221 C1857 rex: :Tn5 Oam29 PamBo) (DeBruijn and Lupski, 1984) was serially diluted and $0.1 \mathrm{~mL}$ aliquots were mixed with $0.1 \mathrm{~mL}$ aliquots of NK5012. The phage were allowed to adsorb at room temperature for $20 \mathrm{~min}$, then $2.5 \mathrm{~mL}$ of molten TB top agar was added, and each mixture was plated on a fresh TB agar plate. After overnight incubation at $42^{\circ} \mathrm{C}, 1-3$ plaques were picked into $0.5 \mathrm{~mL}$ of an overnight NK5012 culture grown in TBYM broth. The mixture was incubated 
20 min at room temperature, mixed with $7.5 \mathrm{~mL}$ of TB top agar, and plated on 3 TB agar plates. The plates were then kept at $42^{\circ} \mathrm{C}$ for no more than $16 \mathrm{~h}$ before scraping the top agar off and vortexing it for $30 \mathrm{sec}$ with $2.0 \mathrm{~mL}$ of $S M$ and 5 drops of chloroform. The cell debris was removed by centrifugation at $12000 \times \mathrm{g}$ for $5 \mathrm{~min}$, and the supernatant was stored at $4^{\circ} \mathrm{C}$. Lysates were titered in the same way as single plaques were isolated at the start of this procedure, and the ability of the lysates to introduce transposons was tested by placing a drop of lysate onto recipient cells spread on an appropriate selective medium. If a lysate was good, several colonies would grow after a $24 \mathrm{~h}$ incubation at $42^{\circ} \mathrm{C}$.

\subsubsection{Transposon Tn 10 Mutagenes is of MP180 and UM178}

MP180 or UM478 was grown to late mid-log phase in TBYM broth. The cells were pelleted by centrifugation at $12000 \times \mathrm{g}$ for $5 \mathrm{~min}$ and the pellet was resuspended in $0.5 \mathrm{~mL}$ (1/20 volume) of TB broth. Phage $\lambda 564$ was added to give a MOI of 0.2 and this was incubated at $37^{\circ} \mathrm{C}$ for 45 to $60 \mathrm{~min}$. Aliquots were plated on 4 to 10 LBT plates and incubated overnight at $42^{\circ} \mathrm{C}$. Any colonies which grew were judged to contain a Tn 10 insertion in the chromosome because the Tn 10 confers tetracycline resistance, while the $\lambda$ phage was unable to survive in MP180 or UM178 at $42^{\circ} \mathrm{C}$. The temperature sensitive phage repressor, c/857, forced the phage to grow lytically at $42^{\circ} \mathrm{C}$, but the phage grew poorly in the su-host because of the amber mutations in essential phage genes. The following day the Tn10 containing colonies were screened for catalase mutants by the $\mathrm{H}_{2} \mathrm{O}_{2}$ drop test.

The stability of the transposon insertions was tested by looking for revertants in the population. Colonies grown on LB plates were picked onto LBT plates to screen for tetracycline sensitive $\left(T C^{S}\right)$ 
revertants. Aliquots of the cultures were spread on Maloy medium, a medium selective for $T_{C}^{S}$ cells (Maloy and Nunn, 1981). Since the complete loss of the transposon making the cells $T C^{S}$ should result in the cell concomitantly regaining catalase activity, $10 \mathrm{mM} \mathrm{H}_{2} \mathrm{O}_{2}$ was added to an early log phase culture to select for catalase positive cells. After $15 \mathrm{~min}, 10^{-1}$ and $10^{-2}$ dilutions of the culture were plated on LB plates, incubated overnight at $37^{\circ} \mathrm{C}$, then scored for catalase the following day.

\subsubsection{Transposon Tn5 Mutagenesis of pLC36-19}

$\lambda$ NK467 was used to isolate Tn5 inserts in JA200/pLC36-19 as described in section 3.5 .2 for MP180, except that colonies were selected on LBK plates. Approximately $1000 \mathrm{Km} R$ colonies were scraped from the agar plates, resuspended in $100 \mathrm{~mL}$ of $\mathrm{LB}$ broth, and grown to mid-log phase. One $\mathrm{mL}$ of this culture was mixed with $1.0 \mathrm{~mL}$ of mid-log phase UM53 and the mixture was shaken at $37^{\circ} \mathrm{C}$ for $1 \mathrm{~h}$.

After the mating, $0.1 \mathrm{~mL}$ aliquots of the mixture were spread on LBSK plates. Small scale alkaline-SDS preparations were done on the resulting colonies, and plasmids larger than pLC36-19 were isolated and restriction enzyme digested to identify the location of the Tns insert.

\subsection{Genetic Mapping of Chromosomal Genes}

\subsubsection{Interrupted Mating}

Interrupted matings were carried out as described by Miller, (1972). The donor and recipient strains were grown to early exponential phase in LB broth. Ten $\mathrm{mL}$ of the recipient culture were placed in a prewarmed $125 \mathrm{~mL}$ Erlenmeyer flask, $0.1 \mathrm{~mL}$ of the donor cells was added, and the incubation was continued with aeration at $37^{\circ} \mathrm{C}$. Each of the 
samples taken at specific time intervals was diluted $1: 10$ in SM, vortexed vigorously for $60 \mathrm{sec}$, then $0.1 \mathrm{~mL}$ aliquots were plated on an appropriate selective medium.

\subsubsection{PI Transduction}

To prepare the P1 lysate needed for the transduction the strain was grown to mid-log phase in LB broth. A $0.1 \mathrm{~mL}$ al iquot of the culture was mixed with $20 \mu 1$ of $\mathrm{Pl}^{\prime}(\mathrm{vir})$ and the mixture was incubated at $37^{\circ} \mathrm{C}$ for $20 \mathrm{~min}$. The phage adsorbed bacteria were mixed with $2.5 \mathrm{~mL}$ of molten $R$ top agar and plated on an LB plate. After overnight incubation at $37^{\circ} \mathrm{C}$, the top agar was scraped off and vortexed with $1.0 \mathrm{~mL}$ of LB broth and 1 drop of chloroform per plate. After allowing the vortexed mixture to sit at room temperature for $30 \mathrm{~min}$ the debris was pelleted at $12000 \times \mathrm{g}$ for $10 \mathrm{~min}$ and the supernatant was collected to provide a P1 lysate.

The strain to be transduced was grown to late log phase $\left(1 \times 10^{9} \mathrm{cel} / \mathrm{s} / \mathrm{mL}\right)$ and collected by centrifugation at $12000 \times \mathrm{g}$ for $5 \mathrm{~min}$. The pellet was resuspended in $1.0 \mathrm{~mL}$ of $1 \mathrm{M} \mathrm{CaCl}_{2}$ and $0.2 \mathrm{~mL}$ aliquots of the cell suspension were mixed with $0.1 \mathrm{~mL}$ of three different dilutions of the P1 lysate. As a control, $0.2 \mathrm{~mL}$ of the cell suspension was added to a fourth tube containing no PI lysate. After incubation for $60 \mathrm{~min}$ at $37^{\circ} \mathrm{C}, 0.2 \mathrm{~mL}$ of $1 \mathrm{M}$ sodium citrate was added. This was mixed with $2.5 \mathrm{~mL}$ of molten $\mathrm{F}$ top agar and plated on the appropriate selective medium. Following a 24-48 $\mathrm{h}$ incubation, colonies were picked onto other media to score for the presence or absence of particular genetic markers. Specific genetic markers were scored as follows: pyrG (CTP synthetase) strains for their requirement for $0.4 \mathrm{mM}$ cytidine; cyst (adenylsulfate reductase) strains for their requirement of 
$0.16 \mathrm{mM}$ cysteine; phes (phenylalanyl-tRNA synthetase) strains for their inability to grow at $37^{\circ} \mathrm{C}$; metB (cystathionine $y$-synthetase) strains for their requirement of $0.16 \mathrm{mM}$ methionine; argH (argininosuccinate lyase) strains for their requirement of $0.16 \mathrm{mM}$ arginine, and PPC (phosphoenolpyruvate carboxylase) strains for their inability to grow on 0.2\% glucose (Bachmann, 1983). The resulting genetic linkage data were used to calculate map distances by the method of Wu (1966). The cotransduction frequency of any two markers, $x$, was substituted into the following formula to give the map distance between markers in minutes:

$$
2(1-\sqrt[3]{x})=\text { distance in minutes. }
$$

\subsection{Assay of Catalase Activity}

\subsubsection{Colony $\mathrm{H}_{2} \mathrm{O}_{2}$ Drop Test}

A drop of $30 \% \mathrm{H}_{2} \mathrm{O}_{2}$ (Fisher) was placed on the edge of each colony. Catalase positive colonies evolved oxygen which appeared as bubbles, while catalase negative colonies bubbled little or not at all.

\subsubsection{Quantitation of Catalase by oxygraph}

Catalase activity was quantitated in a Gilson Model $5 / 6 \mathrm{H}$ oxygraph equipped with a Clark electrode using the method of Rørth and Jensen (1967). Assays were done using a final $\mathrm{H}_{2} \mathrm{O}_{2}$ concentration in the reaction chamber of $4.5 \mathrm{mM}$ or $60 \mathrm{mM}$. One unit of catalase was defined as the amount of enzyme dismutating $1.0 \mu \mathrm{M}$ of $\mathrm{H}_{2} \mathrm{O}_{2}$ per min at $37^{\circ} \mathrm{C}$.

\subsubsection{Catalase and Peroxidase Visualization on Polyacrylamide Gels Cell free crude extracts electrophoresed on native polyacry- Iamide gels as described by Davis (1964), were stained for catalase or}


peroxidase activities using the method of Gregory and Fridovich (1974).

Cells were collected from $250 \mathrm{~mL}$ cultures of $\mathrm{log}$ phase or stationary phase cells and resuspended in $1.0 \mathrm{~mL}$ of $S M$. The cells were sonicated for four-30 $\mathrm{sec}$ periods with a $30 \mathrm{sec}$ incubation on ice between each sonication. Cell debris was removed from the suspension by centrifugation at $12000 \times \mathrm{g}$ for $10 \mathrm{~min}$, leaving a cell free extract which could then be used for electrophoresis. Appropriate volumes of the sample containing $50 \%$ glycerol and $0.025 \%$ bromophenol blue dye were loaded on a $9.5 \%$ polyacrylamide slab gel prepared in $67 \mathrm{mM} \mathrm{Tr}$ is-HCl $\mathrm{pH} 8.1$ and electrophoresed at $25 \mathrm{~mA}$ for $3 \mathrm{~h}$ or until the blue dye reached the bottom. The running buffer was Tris-Glycine, (10 mM Tris-HCl, $70 \mathrm{mM}$ glycine).

The gel was removed from the apparatus and soaked in $50 \mathrm{mM}$ potassium phosphate $\mathrm{pH} 7.0$ containing $0.4 \mathrm{mg} / \mathrm{mL}$ of diaminobenzidine hydrochloride (Sigma) for $45 \mathrm{~min}$ in the dark. If the gel was to be stained for catalase the solution also contained $0.05 \mathrm{mg} / \mathrm{mL}$ of horseradish peroxidase (sigma). The gel was rinsed in water, then soaked for approximately $2 \mathrm{~h}$ in $20 \mathrm{mM} \mathrm{H} \mathrm{H}_{2}$ also prepared in $50 \mathrm{mM}$ potassium phosphate $\mathrm{pH} 7.6$.

Catalase bands appeared as white bands on a brown background while peroxidase bands appeared as brown bands on a light background.

\subsubsection{Ascorbate Induction of Catalase}

Cultures were grown with aeration at $37^{\circ} \mathrm{C}$ in a klett flask containing $25 \mathrm{~mL}$ of LB broth. At a klett of approximately 50 (time=0), $1.0 \mathrm{~mL}$ of freshly prepared $50 \mathrm{mM}$ ascorbate (J. T. Baker Chemical Company) was added. Samples were taken before and after the ascorbate was added and the catalase activity was measured in the oxygraph using $4.5 \mathrm{mM} \mathrm{H} \mathrm{H}_{2} \mathrm{O}_{2}$. 


\subsection{Plasmid DNA Isolation}

\subsubsection{Plasmid Screening Preparations}

I solation of plasmid DNA from bacterial colonies grown on a plasmid selecting medium was done as described by Barnes (1977). Most of the colony was picked with a toothpick and resuspended in $25 \mu \mathrm{L}$ of $50 \mathrm{mM} \mathrm{NaOH}, 0.5 \% \mathrm{SDS}, 5 \mathrm{mM}$ EDTA, and $0.025 \%$ bromocresol green. After a 45 to $60 \mathrm{~min}$ incubation at $68^{\circ} \mathrm{C}, 2.5 \mu \mathrm{L}$ of $25 \%$ Ficoll was added and the sample was loaded on an agarose gel for electrophores is.

\subsubsection{Preparation of Plasmid DNA by the Alkaline Extraction Method} Materials

Media: LB broth + the appropriate plasmid selecting antibiotic

Lysis Buffer: $50 \mathrm{mM}$ glucose $10 \mathrm{mM}$ EDTA

$25 \mathrm{mM}$ Tris-HCl $\mathrm{pH} 8$

Alkaline-SDS: $1 \%$ SOS $10.2 \mathrm{~N} \mathrm{NaOH}$ prepared fresh

High Salt A: $3.0 \mathrm{M}$ potassium acetate

$1.8 \mathrm{M}$ formic acid

High Salt B: 3 M sodium acetate $\mathrm{pH} 4.8$

Acetate-MOPS: 0.1 M sodium acetate

$0.05 \mathrm{M}$ MOPS adjusted to $\mathrm{pH} 8$

TAES: $0.04 \mathrm{M}$ Tris-HCl pH 7.6

$0.1 \mathrm{M}$ sodium acetate $\mathrm{pH} 6.0$

$1.0 \mathrm{mM}$ EDTA

$0.1 \%$ SDS

RNase A: Ribonuclease A (Sigma) was dissolved at a concentration of $2 \mathrm{mg} / \mathrm{mL}$ in TE and boiled for $5 \mathrm{~min}$.

\subsubsection{Small Scale Plasmid Isolation for Restriction Enzme Digestion (Birnboim, 1983) \\ The entire procedure was carried out in microcentrifuge tubes and centrifugations were done in an Eppendorf Centrifuge Model 5412. The}


cell pellet from a $0.5 \mathrm{~mL}$ aliquot of an overnight culture of the plasmid bearing strain was resuspended in $0.1 \mathrm{~mL}$ of lysozyme dissolved in lysis buffer $(1 \mathrm{mg} / \mathrm{mL})$ and placed on ice for $5 \mathrm{~min}$. Two volumes of alkalineSDS were added, the tube was gently inverted, then returned to the ice for another $5 \mathrm{~min}$. One and one half volumes of high salt A was then mixed in by inversion, and the tube was returned to the ice for $15 \mathrm{~min}$. The cell debris was removed with a 15 min centrifugation and the supernatant was transferred to a tube containing $0.9 \mathrm{~mL}$ of ethanol. The tube contents were thoroughly mixed and then stored at $-20^{\circ} \mathrm{C}$ for $30 \mathrm{~min}$. The pellet obtained after a 5 min centrifugation of the mixture was resuspended in $0.1 \mathrm{~mL}$ of acetate-MOPS and reprecipitated with two volumes of cold ethanol. The DNA was pelleted with a 5 min centrifugation, vacuum dried, resuspended in $50 \mu \mathrm{L}$ of water, and stored at $-20^{\circ} \mathrm{C}$.

\subsubsection{Large Scale Plasmid Isolation}

Two $500 \mathrm{~mL}$ cultures of the plasmid harbouring strain were grown with vigorous aeration in two-2L flasks at $37^{\circ} \mathrm{C}$. When the cells reached an $A_{600}$ of 0.6 , chloramphenicol was added to a concentration of $170 \mu \mathrm{g} / \mathrm{mL}$ and the incubation was continued overnight (Clewell, 1972).

Plasmid DNA was isolated by the method of Birnboim and Doly (1979) as outlined below. Cells were harvested by a 10 min centrifugation at $4000 \times \mathrm{g}$, resuspended in $40 \mathrm{~mL}$ of lysis buffer containing $1 \mathrm{mg}$ of lysozyme per $\mathrm{mL}$, and placed on ice for $30 \mathrm{~min}$. Eighty $\mathrm{mL}$ of alkalineSDS was gently mixed in and the lysed cells were returned to the ice bath for another $5 \mathrm{~min}$ before mixing in $60 \mathrm{~mL}$ of high salt $\mathrm{B}$ and continuing the incubation at $0^{\circ} \mathrm{C}$ for another hour. The cell debris was then removed by centrifugation at $27000 \times \mathrm{g}$ for $10 \mathrm{~min}$ and the supernatant was precipitated with two volumes of ethanol for 30 min at 
$-60^{\circ} \mathrm{C}$. The precipitate was collected with a 10 min centrifugation at $4000 \times \mathrm{g}$.

The resulting pellet was dissolved in $40 \mathrm{~mL}$ of TAES and extracted with $40 \mathrm{~mL}$ of phenol-chloroform (1:1). The aqueous phase was removed after the layers were separated by a 10 min centrifugation at $4000 \times \mathrm{g}$. The chloroform-phenol layer was reextracted with another $40 \mathrm{~mL}$ volume of TAES; the aqueous layers were combined and precipitated with two volumes of cold ethanol at $-60^{\circ} \mathrm{C}$. After at least $30 \mathrm{~min}$, the pellet was collected by a $10 \mathrm{~min}$ centrifugation at $4000 \times \mathrm{g}$.

The pellet was dissolved in $10 \mathrm{~mL}$ of $\mathrm{H}_{2} \mathrm{O}$ and $4 \mathrm{~mL}$ of $1 \mathrm{M}$ sodium acetate $\mathrm{pH}$ 8.0. The DNA was precipitated and collected as described in the previous paragraph. After repeating this step once more the pellet was dissolved in $4 \mathrm{~mL}$ of $\mathrm{H}_{2} \mathrm{O}$ and $0.2 \mathrm{~mL}$ of RNase $A$ was added. The mixture was incubated at $37^{\circ} \mathrm{C}$ for $30 \mathrm{~min}$, then mixed with $75 \mu \mathrm{L}$ of 4 M sodium acetate $\mathrm{pH} 6$ and two volumes of room temperature ethanol. The DNA was allowed to precipitate at room temperature for $10 \mathrm{~min}$ and then collected by centrifugation at $12000 \times \mathrm{g}$ for $10 \mathrm{~min}$. Room temperature precipitations were repeated until the supernatant was clear. The pellet was then dried under vacuum and resuspended in 0.5-1.0 mL of TE.

Plasmid vectors for cloning were further purified on a $\mathrm{CsCl}$ gradient (Maniatis et al., 1982). The DNA solution was increased to a volume of $3.0 \mathrm{~mL}$ and mixed with $3.0 \mathrm{~g}$ of $\mathrm{CsCl}$ (Beckman scintillation grade) in a $5.0 \mathrm{~mL}$ nitrocellulose tube. EtBr was added to a concentration $10 \mathrm{mg} / \mathrm{mL}$ and the tube was topped with paraffin oil. The tubes were centrifuged at $35000 \mathrm{rpm}$ in a $50.1 \mathrm{Ti}$ rotor for $40 \mathrm{~h}$ at $20^{\circ} \mathrm{C}$. The tubes were removed and the plasmid band (below the genomic DNA band) was visualized with a UV light and collected from the 
top of the tube with a Pasteur pipette. The DNA was extracted four times with an equal volume of isoamyl alcohol, then dialyzed overnight at $4^{\circ} \mathrm{C}$ against $\mathrm{TE}$ and stored at $-20^{\circ} \mathrm{C}$.

\subsection{E. coli Genoric DNA Isolation}

Materials

Medium: 1 liter of M9 medium supplemented with

$16.7 \mathrm{mM}$ glucose

$5.0 \mathrm{~g}$ tryptone

$1.0 \mathrm{~g}$ yeast extract

Sal ine-EDTA: $0.15 \mathrm{M} \mathrm{NaCl}$

0.1 M EDTA DH 8

Lysozyme Solution: $2 \mathrm{mg} / \mathrm{mL}$ lysozyme chloride (Sigma) dissolved in Saline-EDTA

Tris-SDS: $\quad 0.1 \mathrm{M} \mathrm{Tris-HCL} \mathrm{DH} 7.6$

$0.4 \%$ SDS

$0.1 \mathrm{M} \mathrm{NaCl}$

Sal ine-Citrate: $0.15 \mathrm{M} \mathrm{NaCl}$

$0.015 \mathrm{M}$ trisodium citrate $\mathrm{pH} 7.0$

dilute 1:10 before using

RNase A: 1 mg of $r$ ibonuclease A (sigma) dissolved in $1 \mathrm{~mL}$ of saline-citrate and boiled for $5 \mathrm{~min}$.

One liter of $E$. coli cells was grown overnight with aeration in a $37^{\circ} \mathrm{C}$ incubator room. The cells were collected by a 10 min centr ifugation at $4000 \times g$ and washed once in $100 \mathrm{~mL}$ of saline-EDTA. The washed cells were weighed, then resuspended in $1.0 \mathrm{~mL}$ of saline-EDTA per gram of cells. The suspension was incubated for $30 \mathrm{~min}$ at $37^{\circ} \mathrm{C}$, frozen in a $-60^{\circ} \mathrm{C}$ freezer, then suspended as it thawed in 10 volumes of $\mathrm{Tr}$ is-SDS. Following two more freeze-thaw cycles, the suspension was mixed with an equal volume of buffered phenol and stirred for $20 \min$ at $4^{\circ} \mathrm{C}$. The emulsion was separated by centrifugation at $4000 \times \mathrm{g}$ for $15 \mathrm{~min}$ and the aqueous phase was mixed with two volumes of cold ethanol. The resulting 
precipitate was collected by a 10 min centrifugation at $4000 \times \mathrm{g}$ and then resuspended in $20 \mathrm{~mL}$ of saline-citrate. RNase $A$ was added to a concentration of $50 \mu \mathrm{g} / \mathrm{mL}$. The solution was incubated at $37^{\circ} \mathrm{C}$ for 30 min, cooled, and mixed with $0.3 \mathrm{~mL}$ of $4.0 \mathrm{M}$ sodium acetate $\mathrm{pH} 6.0$. One volume of room temperature ethanol was added, and the DNA was allowed to precipitate for $10 \mathrm{~min}$ at room temperature. The solution was centrifuged for $10 \mathrm{~min}$ at $4000 \times \mathrm{g}$, and pellet was resuspended in salinecitrate, then reprecipitated as described above. When the last step had been repeated until the supernatant was no longer cloudy, the pellet was dried and resuspended in TE to a concentration of $2 \mathrm{mg} / \mathrm{mL}$.

\section{10 DNA Cloning and Restriction Mapping}

\subsubsection{Restriction Enzyme Digests}

Accl, Aval, BamHl, Bcll, Bglll, Clal, Dral, EcoRl, EcoRv, Haelll, Hincll(Hindll), Hindlll, Hpal, Nrul, Pstl, Pvull, Rsal, Sall, SaußAl, Smal, Sspl, Taql, and Xbal were purchased from Boehringer Mannheim Canada (BMC), Ball, Bgll, Kpnl, Ndel, and Sphl were purchased from Bethesda Research Labs (BRL), and Asull was purchased from Promega Biotec. Restriction enzyme digests were done for $2 \mathrm{~h}$ in 10 or $20 \mu \mathrm{L}$ volumes with 1 to 10 units of enzyme per $\mu g$ of DNA at the temperature recommended by BMC. The incubation buffer chosen (high, medium or low salt) was the one closest to the BMC recommended buffer except in the cases of Smal and Sphl whose buffers were prepared specifically as recommended by BMC.

\begin{tabular}{ccccc} 
Buffer & $\mathrm{NaCl}$ & $\mathrm{Tris}-\mathrm{HCl} \mathrm{pH7.5}$ & DTT & $\mathrm{MgCl}_{2}$ \\
\hline low & - & $10 \mathrm{mM}$ & $1 \mathrm{mH}$ & $10 \mathrm{mM}$ \\
medium & $50 \mathrm{mH}$ & $10 \mathrm{mM}$ & $1 \mathrm{mH}$ & $10 \mathrm{mH}$ \\
high & $100 \mathrm{mM}$ & $50 \mathrm{mM}$ & $1 \mathrm{mH}$ & $10 \mathrm{mM}$
\end{tabular}

(Maniatis et al., 1982) 


\subsubsection{Gel Electrophoresis of DNA}

Materials

$6 \times$ Loading Buffer: $100 \mathrm{mM}$ EDTA

$0.25 \%$ bromophenol blue

$15 \%$ Ficoll

(Maniatis et al., 1982)

$10 \times$ TBE Electrophores is Buffer (Maniatis et al., 1982)

per liter:

$\begin{array}{ccl}108 & \mathrm{~g} & \text { Trizma base (Sigma) } \\ 55 & \mathrm{~g} & \text { boric acid } \\ 8.5 \mathrm{~g} & \mathrm{Na}_{2} \text { EDTA. } 2 \mathrm{H}_{2} \mathrm{O}\end{array}$

$30 \%$ Acrylamide

per $100 \mathrm{~mL}$ :

$29 \mathrm{~g}$ acrylamide (Bio-Rad Laboratories)

$1 \mathrm{~g} \quad \mathrm{NN}$ '-methylene bisacrylamide (sigma)

Make up to $100 \mathrm{~mL}$ with distilled water.

\subsubsection{Preparation of DNA Samples}

Samples containing 0.5 to $1.5 \mu g$ of restricted DNA were mixed

6:1 with $6 \times$ loading buffer. Hindlll, ECORI, BamHl, Hpal, or Haelll

digested $\lambda$ DNA (BMC) and DNA fragments ranging from 1 to $12 \mathrm{~kb}$ in

size and each differing in size by 1 kb (BRL's 1 kb ladder) were commonly

used as the molecular weight markers for agarose gels while $\lambda$ DNA

digested with Ndel or PBR322 DNA digested with Haelll, Hpal, or NCil

served as the molecular weight markers for acrylamide gels.

\subsubsection{Agarose Gel Preparation and Electrophoresis}

Agarose gels were used to identify or separate fragments between

0.5 and $26 \mathrm{~kb}$ in size. Gels were prepared by boiling agarose (Sigma

Type 11: medium EEO) in $1 \times$ TBE until it was dissolved. For a $15.5 \times$

$15.5 \mathrm{~cm} 0.8 \% \mathrm{gel}, 0.64 \mathrm{~g}$ of agarose was dissolved in $80 \mathrm{~mL}$ of $1 \times$ TBE.

When the agarose had cooled to $55^{\circ} \mathrm{C}$ the gel was poured, the well maker

was placed in the molten agarose, and the gel was left to harden. The

well maker was then removed and the gel was submerged in a Bio-Rad DNA 
Sub-Cell Electrophoresis system filled with $1 \times$ TBE. The samples were pipetted into the wells and $80 \mathrm{~V}$ was applied for $3.5 \mathrm{~h}$ or until the bromophenol blue was $3 / 4$ of the way down the gel.

\subsubsection{Preparation and Electrophores is of Acrylamide Gels}

Polyacrylamide gels $(8 \%)$ were used to identify and separate DNA fragments between 20 and 600 bp in size. A mixture of $10 \mathrm{~mL}$ of $30 \%$ acrylamide, and $30 \mathrm{~mL}$ of $1 \times$ TBE was degassed and then mixed with $20 \mathrm{HL}$ of TEMED and $30 \mathrm{mg}$ of ammonium persulfate. The acrylamide mixture was then quickly poured between two $15 \times 15 \mathrm{~cm}$ vertical gel plates and the well maker was placed $1 \mathrm{~cm}$ into the acrylamide. After the gel had polymerized the well maker was removed and the wells were washed before adding $1 \times$ TBE buffer and loading the samples. The gel was placed in a Bio-Rad Protean Dual Slab Cell and run at $100 \mathrm{~V}$ until the bromophenol blue reached the bottom (about $3 \mathrm{~h}$ ).

\subsubsection{Staining, Photographing, and Sizing of DNA Bands}

The gels were removed from the electrophoresis apparatus and placed in $1 \times$ TBE containing $0.05 \mu \mathrm{g} / \mathrm{mL}$ of EtBr for $30 \mathrm{~min}$. The gel was then photographed with an indirect UV light source using a polaroid MP4 Land Camera equipped with a Kodak $22 \mathrm{~A}$ Wratten filter and Polaroid Type $667 \mathrm{film}$. The exposure time was 0.5 to $1.5 \mathrm{~min}$ at an aperture of 5.6. The sizes of the DNA fragments were determined from the photograph by measuring the distance the fragments had travelled from the origin. The distance the standard size markers had migrated from the origin was plotted as a function of the in of their size (bp) to make a standard curve from which the size of the unknown bands could be determined by comparison. 


\subsubsection{Alkaline Phosphatase Treatment of DNA}

Alkaline phosphatase was used to remove the 5'-terminal phosphate groups from restricted plasmid vectors, preventing re-ligation of the vector without insert DNA. Following the BMC procedure submitted by Dr. Luis Villareal, 6-8 units of calf intestine alkaline phosphatase (BMC) was added for the last 20 min of the restriction enzyme digest. The reaction was stopped by heating the sample at $65^{\circ} \mathrm{C}$ for $10 \mathrm{~min}$ in $20 \mathrm{mM}$ EDTA and $0.5 \%$ SDS. The DNA was then diluted with one volume of $\mathrm{TE}+250 \mathrm{mM} \mathrm{NaCl}$ and extracted with one volume of buffered phenol. The aqueous phase was precipitated with two volumes of ethanol and the DNA that was collected by centrifugation for $15 \mathrm{~min}$ was air dried and resuspended in water.

\subsubsection{Ligations}

Approximately $0.1 \mu \mathrm{g}$ of the plasmid vector which had been digested and dephosphorylataed as described previously was mixed with $0.3 \mathrm{Hg}$ of digested insert DNA. BRL $5 \times 1$ igation buffer was added to give a final concentration of $50 \mathrm{mM} \mathrm{Tris-HCl} \mathrm{pH} 7.6,10 \mathrm{mM} \mathrm{MgCl} 2,5 \%$ PEG 8000, $1 \mathrm{mM} \mathrm{ATP}$, and $1 \mathrm{mM}$ DTT. The volume was made up to 10 or $20 \mu \mathrm{L}$ with sterile distilled water. One unit of T4 DNA ligase (BRL) was added if the fragments to be ligated were blunt ended and 0.5 units were added if the ends were "sticky". The components were well mixed, sealed in a capillary tube and incubated overnight at room temperature. M13 vectors were not dephosphorylated before the ligations and only $0.07 \mu \mathrm{g}$ of the vector was used for a ligation.

\subsubsection{Transformation of E. coli}

A $10 \mathrm{~mL}$ mid-log phase culture of E. coli grown in LB broth was 
placed on ice for 15 min before collecting the cells by centrifugation for 5 min at $12000 \times \mathrm{g}$. The pellet was resuspended in $10 \mathrm{~mL}$ of $0.1 \mathrm{M}$ $\mathrm{CaCl}_{2}$ and placed on ice for $20 \mathrm{~min}$. The cells were once again pelleted by centrifugation at $12000 \times \mathrm{g}$ for $5 \mathrm{~min}$ and then gently resuspended in $0.5 \mathrm{~mL}$ of $0.1 \mathrm{M} \mathrm{CaCl}_{2}$. The competent cells were stored $\mathrm{ON}$ at $4^{\circ} \mathrm{C}$ and the following day $0.2 \mathrm{~mL}$ aliquots were mixed with the ligation mixtures and placed on ice for $1 \mathrm{~h}$. The cells were then placed in a $42^{\circ} \mathrm{C}$ waterbath for $90 \mathrm{sec}$, diluted with $1.0 \mathrm{~mL}$ of LB broth, and incubated at $37^{\circ} \mathrm{C}$ for 1 to $2 \mathrm{~h}$ to allow expression of the plasmid encoded proteins before aliquots of 0.05 to $0.2 \mathrm{~mL}$ were plated on LB selection plates.

\subsubsection{Screening for Recombinant Plasmids}

\subsubsection{1 pAT153 Recombinants}

The $3.6 \mathrm{~kb}$ plasmid vector PAT153 has genes conferring resistance to both tetracycline and ampicillin. Fragments were cloned into the unique HindlII and Sphl sites found in the PAT153 TCR gene. Transformed cells were plated on LBA plates which allowed both recombinants and nonrecombinants to grow. The colonies were screened for plasmids with inserts by picking them onto LBT plates. Cells unable to grow on the LBT plate probably had inserts in the tetracycline gene and DNA was then isolated and characterized by restriction enzyme digestion.

\subsubsection{2 pKK232-8 Recombinants}

The promoter cloning vector pKK232-8 carries the bla gene conferring ampicillin resistance as well as a promoterless chloramphenicol acetyltransferase gene (Brosius, 1984). Bglll fragments were cloned into the unique BamHl site, part of a multiple cloning site preceding the chloramphenicol acetyltransferase gene. Plasmidcontaining colonies were first selected with LBA plates and then 
streaked onto increasing concentrations of chloramphenicol to identify promoter containing recombinants. DNA from clones exhibiting the highest resistance to chloramphenicol was prepared and characterized by restriction enzyme digestion.

\subsubsection{A13mp18/19 Reconbinants}

The M13mp18/19 phage are commonly used for subcloning fragments for dideoxy sequencing because they secrete ss DNA and they allow the single step identification of recombinant clones. The host strain into which these phage were transformed was $\mathrm{Lac}^{-}$but became $\mathrm{Lac}^{+}$if it was complemented by the M13 vector. The Lac ${ }^{+}$nonrecombinant phage produced blue plaques on Xgal and IPTG while recombinant M13 phage had a fragment interrupting the $\beta$-galactosidase gene and could no longer complement the host, resulting in clear plaques.

\subsubsection{Elution of DNA Fragments from Agarose Gels}

\subsubsection{Elution of DNA Fragments for Restriction Enzyme Digestion}

The DNA band of interest was cut out from an EtBr stained agarose gel under indirect UV illumination taking care not to remove excess agarose with the DNA band. The DNA was then eluted as described by Selker et al (1976). The gel was suspended as thoroughly as possible in $10 \mathrm{mM} \mathrm{Tris-HCl} \mathrm{pH} 8.0,2 \mathrm{mM}$ EDTA, and $1 \mathrm{M} \mathrm{NaCl}$ by repeatedly forcing it through a 20-gauge needle. After incubating the suspension for $16 \mathrm{~h}$ at $47^{\circ} \mathrm{C}$, the gel was sedimented by centrifugation for $30 \mathrm{~min}$ at $18000 \times \mathrm{g}$, and the supernatant was collected. Following a phenol extraction, the DNA was precipitated with three volumes of ethanol, stored at $-60^{\circ} \mathrm{C}$ for $30 \mathrm{~min}$, then collected by centrifugation at $12000 \times \mathrm{g}$ for $20 \mathrm{~min}$. The DNA was then dried and used for restriction enzyme digestion. 


\subsubsection{Elution of DNA Fragments for Nick Translation or Cloning}

The DNA band of interest was cut out from an EtBr stained gel as described in 3.10.7.1 and the DNA was eluted using a GENECLEAN Kit, following the instructions and using the solutions supplied with the kit (Bio101 Inc.). This procedure was based on data from vogelstein and Gillespie (1979). The agarose was dissolved in a sodium iadide solution, the DNA was bound to a silica matrix (glassmilk), and the contaminating agarose was washed away with an ethanol-salt solution. The DNA was then released from the "glassmilk" by heating it in water. DNA of excellent quality was recovered with less than a $20 \%$ loss.

\subsection{DNA/DNA Hybridizations}

\subsubsection{Preparation of Southern Blots}

Materials

Denaturing Solution: $\begin{aligned} 1.5 \mathrm{M} \mathrm{NaCl} \\ 0.5 \mathrm{M} \mathrm{NaOH}\end{aligned}$

Neutralizing Solution: $1.0 \mathrm{M}$ Tris-HCl pH 8.0 $1.5 \mathrm{M} \mathrm{NaCl}$

$20 \times$ SSC: $3.0 \mathrm{M} \mathrm{NaCl}$

3.0 M sodium citrate

Southern blots were prepared as described by Maniatis et al.(1982). DNA samples to be blotted were run on $0.8 \%$ agarose gels, stained and photographed as outlined in section 3.10.2. Excess agarose was trimmed away and the gel was agitated in several volumes of denaturing solution for $1 \mathrm{~h}$ at room temperature. The denaturing solution was replaced with neutralizing solution and the agitation was continued for $1 \mathrm{~h}$.

If only one blot was to be prepared from the gel, a piece of Whatman 3MM paper slightly wider than the gel was placed on top of a glass plate with the ends extending into a tray of $10 \times$ SSC allowing it 
to act as a wick through which buffer could move by capillary action.

The gel was placed on top of the filter paper and framed with Saran Wrap to prevent the buffer from moving around rather than through the gel. A nitrocellulose filter (Millipore HAWP) that had been floated on $2 \times$ SSC for 2-3 min was placed on top of the gel. Any bubbles were carefully removed before 2 or 3 Whatman 3MM filter papers approximately the same size as the gel were placed on top. A three inch stack of paper towels, and finally a $500 \mathrm{~g}$ weight was placed on top of this. The transfer was allowed to proceed for at least $16 \mathrm{~h}$, then the nitro-cellulose filter was removed and soaked in $6 \times$ SSC for $5 \mathrm{~min}$. The filter was air dried and then baked for $2 \mathrm{~h}$ at $80^{\circ} \mathrm{C}$.

Double blots were prepared in a similar way, except that the gel was sandwiched between two nitrocellulose filters, two sets of Whatman 3MM paper, and two bundles of paper towels. The buffer in the gel provided enough moisture for the transfer of the DNA in both directions.

\subsubsection{Nick Translation}

Materials

$5 \times$ Nick Translation Buffer: $0.1 \mathrm{mM}$ dCTP (Pharmacia)
$0.1 \mathrm{mM}$ dGTP "
$0.1 \mathrm{mM}$ dTTP "
$0.05 \mathrm{M} \mathrm{MgCl} 2$
$0.5 \mathrm{mM}$ DTT (BMC)
$0.25 \mathrm{M} \mathrm{Tris-HCl} \mathrm{pH} 7.6$
$250 \mu \mathrm{m} / \mathrm{mL} \mathrm{BSA} \mathrm{(BMC)}$
prepared in HPLC grade water (Fisher)

DNase 1: $0.1 \mu \mathrm{g} / \mathrm{mL}$ prepared by dilution of a $1 \mathrm{mg} / \mathrm{mL}$ stock into $1 \times$ nick translation buffer containing $50 \%$ glycerol.

Sephadex 6-50 (Sigma): Sephadex was stored at $4^{\circ} \mathrm{C}$ after it was allowed to expand in several volumes of TE overnight at room temperature.

The nick translation procedure was modified slightly from Maniatis et al. (4982). A $44 \mu \mathrm{L}$ reaction mixture containing 0.5 to $1.0 \mu \mathrm{g}$ of DNA, $10 \mu \mathrm{L}$ of $5 \times$ nick translation buffer and $1 \mu \mathrm{L}$ of 
DNA Polymerase 1 (Pharmacia $7300 \mathrm{u} / \mathrm{mL}$ ) was prepared. Five $\mu L$ of dATP [ $\alpha^{32}$ p] purchased from New England Nuclear (NEN) having a specific activity of $3000 \mu \mathrm{Ci} / \mathrm{mM}$ and a concentration of $0.0033 \mu \mathrm{M} / \mathrm{mL}$ was added and then $1 \mathrm{\mu L}$ of DNase 1 was added. The contents were thoroughly mixed, then placed at $16^{\circ} \mathrm{C}$ for $1-1.5 \mathrm{~h}$.

The nick translation mixture was immediately loaded on a small

(5 mL) Sephadex 6-50 column to separate the unincorporated nucleotides from the labelled DNA. The peaks were monitored with a Geiger counter (Ludlum Measurements Inc.) and then a 1 HL aliquot was counted in a Beckman LS-230 liquid scintillation counter. The labelled DNA was then frozen at $-20^{\circ} \mathrm{C}$ until required.

\subsubsection{Hybridization (Maniatis et al., 1982)}

Materials:

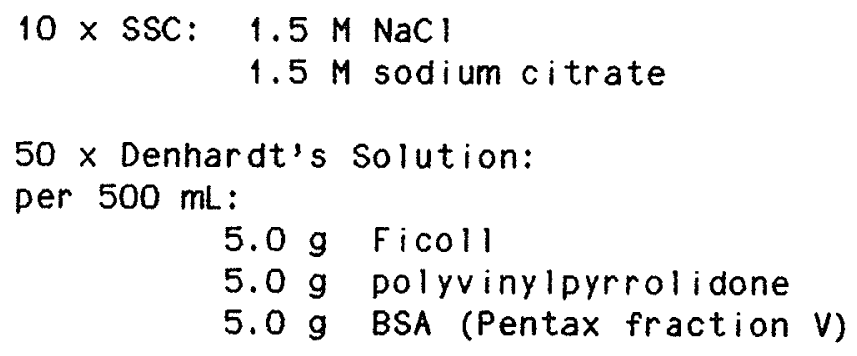

Salmon sperm DNA: Stock solution of $10 \mathrm{mg} / \mathrm{mL}$ were prepared in water, sheared by passage through a 20 gauge needle, then boiled for $5 \mathrm{~min}$ and stored at $-20^{\circ} \mathrm{C}$.

Prehybridization Fluid: $6 \times$ SSC

$$
\begin{aligned}
& 0.5 \% \text { SDS } \\
& 5 \times \text { Denhardt's Solution } \\
& 100 \mu \mathrm{g} / \mathrm{mL} \text { salmon sperm DNA }
\end{aligned}
$$

Hybridization Fluid: Prehybridization fluid plus 0.01 M EDTA

The filter to be hybridized was first wet from underneath with $6 \times S S C$, then irmersed in $6 \times S S C$ for $2 \mathrm{~min}$. The filter was sealed in a bag with $0.2 \mathrm{~mL} / \mathrm{cm}^{2}$ of prehybridization fluid and incubated with agitation at $68^{\circ} \mathrm{C}$. After $4 \mathrm{~h}$, the prehybridization fluid was replaced 
with hybridization fluid. The $32 \mathrm{p}$-labelled DNA probe $\left(3-20 \times 10^{7} \mathrm{cpm}\right)$ was boiled for $5 \mathrm{~min}$ then added to the bag. The hybridization was agitated overnight at $68^{\circ} \mathrm{C}$.

After $16 \mathrm{~h}$ or more, the hybridization solution was removed and the filter was immersed in $2 \times S S C / 0.5 \%$ SDS. The filter was gently agitated for $5 \mathrm{~min}$ at room temperature, then transferred to $2 \times S S C / 0.1 \%$ SDS and agitated for another $15 \mathrm{~min}$ at room temperature. The filters were then placed in $0.1 \times S S C / 0.5 \%$ SDS and agitated for $2 \mathrm{~h}$ at $68^{\circ} \mathrm{C}$. The wash was replaced and the incubation was continued another $30 \mathrm{~min}$. The filters were then dried and exposed to Kodak X-Omat-AR X-ray film in a Picker Source One cassette containing one Cronex Quantalll intensifying screen (Du Pont) and kept at $-70^{\circ} \mathrm{C}$ for $8-72 \mathrm{~h}$ before developing the film. X-ray film was developed by placing it in developer for $3 \mathrm{~min}$, then rinsing it well with water, and placing it in fixer for $3 \mathrm{~min}$. The film was then well rinsed with water and dried.

\subsection{Isolation of Plasmid Deletion Mutants}

\subsubsection{Deletion of Specific Fragments from Plasmids}

When one or more restriction fragments surrounded by the same restriction enzyme site were to be deleted, $0.5 \mu \mathrm{g}$ of the DNA was digested with the enzyme surrounding the fragment, the DNA was diluted to $50 \mu \mathrm{L}$, and ligated overnight at $16^{\circ} \mathrm{C}$.

\subsubsection{BAL31 Deletion Mutagenes is of pBT22}

Nuclease BAL31's ability to degrade double stranded DNA from the ends inward makes it a useful tool for the definition of phenotypic boundaries. This principle was applied to the definition of one end of katG using a unique sall site located in a nonessential part of the 
vector, near one end of the insert.

The BAL31 deletion mutagenesis was done using the method described by Frey et al. (1984). Ten $\mu \mathrm{g}$ of PBT22 DNA was digested with Sall in a $40 \mu \mathrm{L}$ volume and a $2 \mu \mathrm{L}$ sample was run on a gel to verify that the restriction digest was complete. Additions of 0.1 volumes of $3 M$ sodium acetate $\mathrm{pH} 4.8$ and 0.7 volumes of isopropanol were made and the sample was placed at $-20^{\circ} \mathrm{C}$ for at least $30 \mathrm{~min}$. The precipitated DNA was collected with a 10 min centrifugation, the pellet was washed twice with $80 \%$ ethanol, and left to air dry.

The pellet was dissolved in $110 \mu \mathrm{L}$ of BAL31 incubation buffer (20 mM Tris-HCl pH 8.0, $600 \mathrm{mM} \mathrm{NaCl}, 12 \mathrm{mM} \mathrm{MgCl} 2,12 \mathrm{mM} \mathrm{CaCl} 2,1 \mathrm{mM}$ EDTA) and the sample was prewarmed at $30^{\circ} \mathrm{C}$. At $0,2,5,10$, and $15 \mathrm{~min}$, a $25 \mu \mathrm{L}$ sample was taken, $5 \mu \mathrm{L}$ of ice cold $0.2 \mathrm{M}$ EDTA pH 8.0 and $80 \mu \mathrm{L}$ of ice cold water were added, then the sample was placed on ice. When the time course was completed, each sample was precipitated in the same way as in the first part of the procedure. Each DNA sample was dissolved in $10 \mu \mathrm{L}$ of TE buffer and $5 \mu \mathrm{L}$ aliquots of the 0 and 15 min time samples were run on a gel to make sure that BAL31 was active. The remaining samples were ligated as described in section 3.10.4, except that they were kept at $14^{\circ} \mathrm{C}$ for $2-3 \mathrm{~h}$ and then diluted with $90 \mu \mathrm{L}$ of ligation buffer before continuing the incubation overnight at $14^{\circ} \mathrm{C}$. The dilution was to prevent intramolecular ligation.

The ligations were transformed into UM228 and plasmid containing cells were selected on LBA. Catalase was checked by the $\mathrm{H}_{2} \mathrm{O}_{2}$ drop test and colonies were screened for deletion plasmids by rapid plasmid screening prepartions. Plasmids of interest were further characterized by restriction enzyme digestion. 


\subsection{Maxicell Analys is of Plasmid Encoded Polypeptides}

The maxicell procedure was carried out as described by sancar et al. (1979), but with minor modifications. Plasmid bearing cells were grown to early mid-log phase $\left(3 \times 10^{8} \mathrm{cell} / \mathrm{s} / \mathrm{mL}\right)$ in $\mathrm{K}$ Medium containing the appropriate plasmid selecting antibiotic. The cells were then irradiated in a sterile Petri dish with a Mineralight $115 \mathrm{~V}$ UV lamp at a distance of $36 \mathrm{~cm}$. The irradiation time (earliest time at which $100 \%$ killing occurred) was assayed and found to be $12 \mathrm{sec}$ for CSR603 and $30 \mathrm{sec}$ for UM262. The irradiated cells were transferred to a sterile $125 \mathrm{~mL}$ Er lenmeyer flask and shaken at $37^{\circ} \mathrm{C}$ for $1 \mathrm{~h}$. Cycloserine (100 mg/mL prepared in $0.1 \mathrm{M}$ phosphate buffer $\mathrm{pH} 8.0$ ) was added to a final concentration of $100 \mu \mathrm{g} / \mathrm{mL}$ and then the $37^{\circ} \mathrm{C}$ incubation was continued overnight. The following morning the cells were collected by centrifugation at $12000 \times g$ and washed twice in Hershey's Salts. The washed pellet was then resuspended in $5.0 \mathrm{~mL}$ of Hershey's Medium and $20 \mu \mathrm{Ci}$ of ${ }^{14} \mathrm{C}$-labelled mixed amino acids $(0.05 \mathrm{mC} / 0.5 \mathrm{~mL})$ purchased from NEN were added. The cells were then incubated at $37^{\circ} \mathrm{C}$ for $1.5 \mathrm{~h}$ with aeration to allow ${ }^{14} \mathrm{C}$-labelled plasmid encoded polypeptides to be synthesized. The cells were harvested in a microcentrifuge tube by repeated 3 min spins in an Eppendorf Model 5412 centrifuge. After one wash in $0.5 \mathrm{~mL}$ of $S M$, the cells were evenly resuspended in $40 \mu \mathrm{L}$ of sample buffer ( $2 \%$ SDS, $0.2 \mathrm{MMSH}, 8 \%$ glycerol, $63 \mathrm{mM}$ Tris $\mathrm{pH} 6.8$ ) and frozen at $-20^{\circ} \mathrm{C}$ until they were to be loaded on a gel.

Just before loading the SDS-PAGE gel, $15 \mu \mathrm{L}$ of the sample was mixed with $2 \mu \mathrm{L}$ of tracking dye ( $0.25 \%$ bromophenol blue) and boiled for $3 \mathrm{~min}$. The samples were loaded, electrophoresed, stained, and 
destained as described in section 3.14.3.

Following destaining, the gel was prepared for fluorography using the procedure of Boulnois and Tirmis (1984). The fixer solution was replaced with DMSO and agitated gently for $30 \mathrm{~min}$. The DMSO was replaced with fresh DMSO and agitation was continued another $30 \mathrm{~min}$. The gel was placed in $22 \%(w / v)$ PPO in DMSO, and after $1 \mathrm{~h}$, the solution was removed and replaced with water. After replacing the water several times over the course of an hour, the gel was dried on filter paper.

The dried gel was exposed to $x$-ray film as described in section 3.11.3, except the cassette contained two intensifying screens, and the exposure was done for 5-16 days at $-70^{\circ} \mathrm{C}$.

\subsection{HPI Protein Purification and Analys is}

\subsubsection{Partial Purification of Catalase HPI}

Two-1 L LB cultures of the desired E. coli strain were grown overnight at $37^{\circ} \mathrm{C}$ on a rotary shaker. The cells were collected by centrifugation, weighed, and frozen at $-60^{\circ} \mathrm{C}$.

The frozen cells were thawed at $37^{\circ} \mathrm{C}$ and resuspended at $4^{\circ} \mathrm{C}$ in $400 \mathrm{~mL}$ of $\mathrm{KPi}(50 \mathrm{mM}$ potassium phosphate $\mathrm{pH} 7.0$ ) per $75 \mathrm{~g}$ of cells until a smooth slurry was obtained. The cells were then lysed by passing them through an Aminco French Pressure Cell Press at 20000 psi. The lysate was centrifuged at $7000 \times \mathrm{g}$ for $15 \mathrm{~min}$ and the supernatant was collected. The preceding step was repeated and then $2.5 \%(\mathrm{w} / \mathrm{v})$ streptomycin sulphate (BMC) was added and the slurry was allowed to stir for $50 \mathrm{~min}$ at $4^{\circ} \mathrm{C}$. The precipitate was removed by centrifugation for 15 min at $7000 \times g$ and the supernatant was fractionated by precipitation with $65 \%$ ammonium sulfate (Schwarz Mann). After stirring $45 \mathrm{~min}$ at $4^{\circ} \mathrm{C}$, 
the precipitate was collected by centrifugation for $15 \mathrm{~min}$ at $12000 \times \mathrm{g}$. The pellet was resuspended in a minimal volume of $\mathrm{KPi}$ and dialyzed overnight against $4 \mathrm{~L}$ of $\mathrm{KPi}$. Five hundred mg of protein was loaded onto a $2.8 \times 60 \mathrm{~cm}$ DEAE-Sephadex column and washed with KPi until the $\mathrm{A}_{260}$ fell below 0.01 . Fifty $\mathrm{mM} \mathrm{NaCl}$ was then run through the column and 75 drop fractions were collected. The protein peak was pooled and concentrated by an $80 \%$ ammonium sulfate precipitation. The pellet was resuspended in the smallest volume possible, dialyzed overnight against $\mathrm{KPi}$, centrifuged to clarify, and stored at $-20^{\circ} \mathrm{C}$.

If catalase was active, it was assayed after each step.

\subsubsection{Immunodiffusion Analys is}

Immunodiffusion plates containing $0.9 \%(w / v) ~ N a C l$ and $1.0 \%(w / v)$ agar were prepared. HPl-antisera prepared in a rabbit (Loewen et al., 1985b) was placed in the centre well with the test samples surrounding it and diffusion was allowed to proceed overnight at $37^{\circ} \mathrm{C}$.

\subsubsection{SDS-Polyacrylamide Gel Electrophores is (PAGE)}

Gels for SDS-PAGE were prepared and electrophoresed with the BioRad Protean Dual Slab Cell apparatus described in section 3.10.2.3 for polyacrylamide DNA electrophoresis. An $8 \%$ polyacrylamide, $0.1 \%$ SDS running gel was prepared in $\mathrm{Tr}$ is $-\mathrm{HCl} \mathrm{pH} 8.8$ and after polymerization it was overlayered with a $4 \%$ polyacrylamide, $0.1 \%$ SDS stacking gel prepared in Tris-HCl pH 6.8 .

Samples to be run on the gel were mixed with an equal volume of sample buffer (see section 3.13 for contents), boiled for $3 \mathrm{~min}$, mixed 1:10 with $0.25 \%$ bromophenol blue, and loaded on the gel. The gels were run in $0.1 \%$ SDS, $25 \mathrm{mM} \mathrm{Tris,} 0.2 \mathrm{Mglycine}$ at $25 \mathrm{~mA}$ for about $3 \mathrm{~h}$. The gel was then removed from the apparatus and stained overnight in Coomassie 
Brilliant Blue (0.25\% in $10 \%$ acetic acid and $40 \%$ methanol). The stain was replaced the following day with destain, containing $7 \%$ methanol and 15\% acetic acid. The destain was repeatedly replaced until the protein bands appeared as dark blue bands against a light blue background. The gel was then transferred to filter paper and dried under vacuum for $2-3 \mathrm{~h}$. Molecular weight standards were purchased from sigma. The in of the known protein molecular weights was plotted as a function of the distance the proteins had travelled from the origin. Unknown protein molecular weights were then calculated by a comparison of the distances migrated with the standard curve.

\subsubsection{Cyanogen Bromide Cleavage of HPI Catalase}

HPI catalase was purified by J. Switala using the method previously described by Loewen and Switala (1986). Cyanogen bromide peptides were generated from catalase following the method of steers et al. (1965). Forty $\mathrm{mg}$ of protein was lyophilized, then resuspended at a concentration of $15 \mathrm{mg} / \mathrm{mL}$ in $70 \%$ formic acid. Cyanogen bromide was added to a concentration of $18 \mathrm{mg} / \mathrm{mL}$ and the sample was allowed to react overnight at room temperature in the dark. Five volumes of $\mathrm{H}_{2} \mathrm{O}$ were added and the sample was lyophilized. The peptides were citraconallated as described by Atassi and Habeeb (1972). The sample was resuspended in $9.0 \mathrm{~mL}$ of $6 \mathrm{M}$ guanidine-HCl (BRL), $0.2 \mathrm{M} \mathrm{N}$-ethylmorphol ine acetate $\mathrm{pH} 8.5$ and $300 \mu \mathrm{L}$ of citraconic anhydride was added in $50 \mu \mathrm{L}$ a liquots while maintaining the $\mathrm{pH}$ at 8-9. After stirring for $2 \mathrm{~h}$, the sample was dialyzed against $0.1 \mathrm{MNH}_{4} \mathrm{HCO}_{3}$, lyophilized, and resuspended in $0.5 \mathrm{~mL}$ of $\mathrm{H}_{2} \mathrm{O}$. The sample was then loaded on a Sephadex G-75-40 column and the resulting peaks were further separated by HPLC. Protein from the peaks was lyophilized and stored at $-20^{\circ}$ until it was prepared 
for amino acid sequencing.

\subsubsection{Amino Acid Sequence Determination}

The amino acid sequence determinations were done by $\mathrm{Dr}$. $H$. Duckworth and $w$. Taylor in the Department of Chemistry, University of Manitoba. The cyanogen bromide generated peptides were sequenced in an Beckman Model $890 \mathrm{C}$ Sequencer. Samples were submitted to 8 to 21 cycles of Edman degradation and the amino acid derivatives in the fractions collected were identified by HPLC. Amino acid assignments were made by comparing the cycle of interest to the preceding cycle and looking for the appearance of new peaks. The elution time of the peak was then compared to the amino acid standards to identify the peak. In cases where more than one amino acid had almost the same elution time, the proper identification was made by running the amino acid standards and the unknown simultaneously.

\subsection{Dideoxy Chain Termination Sequencing}

\subsubsection{Preparation of M13 Vectors}

JM101 was prepared for M13 infection as described by Dr. L. Donald (personal communication). A flask containing $100 \mathrm{~mL}$ of $2 \times Y T$ was inoculated with $1.0 \mathrm{~mL}$ of an overnight culture of JM101 and aerated on a rotary shaker bed at $37^{\circ} \mathrm{C}$ for $1.5 \mathrm{~h}$. A $5.0 \mathrm{~mL}$ aliquot was then transferred to $500 \mathrm{~mL}$ of $2 \times Y T$ and after incubation of this flask under the same conditions for $1.5 \mathrm{~h}, a 1.0 \mathrm{~mL}$ inoculum of M13 phage was added. (The M13 phage was prepared by inoculating a single plaque into $1.5 \mathrm{~mL}$ of log phase JM101 grown in $2 X Y T$ and incubating this overnight at $37^{\circ} \mathrm{C}$ with aeration.) The $500 \mathrm{~mL}$ culture was allowed to continue shaking at $37^{\circ} \mathrm{C}$ for 5-8 $\mathrm{h}$ before the cells were collected, washed in SM, and the RF 
(replicative form) ONA was prepared as described for large scale plasmid preparation in section 3.8.2.2.

\subsubsection{Cloning into $M 13$ Vectors}

Restriction enzyme digests and ligations were carried out as described in section 3.10. JM101 was prepared for the transformation as described in section 3.10 with two exceptions: competent JM101 cells were always used irmediately, and the heat shock was done at $37^{\circ} \mathrm{C}$ for 15 min. After the heat shock, the cells were mixed with 100 mM IPTG, $2 \% \mathrm{Xgal}$ (in dimethyl formamide), and $0.2 \mathrm{~mL}$ of $\log$ phase JM101 grown in 2XYT. This mixture was then mixed with $2.5 \mathrm{~mL}$ of LB top agar and immediately plated on an LB plate. These plates were then inverted and incubated at $37^{\circ} \mathrm{C}$ for $8-20 \mathrm{~h}$.

\subsubsection{Preparation of SS Template}

Materials

PEG/NaCl: $20 \%(\mathrm{~W} / \mathrm{V}$ ) polyethylene glycol 6000 (Fisher) $2.5 \mathrm{M} \mathrm{NaCl}$

store at $4^{\circ} \mathrm{C}$

The recombinant M13 phage plaques, prepared as described in the preceding section were clear (sometimes referred to as white) but mixed with numerous wild type M13 blue plaques. A clear plaque was inoculated with a toothpick into a $50 \mathrm{~mL}$ tube containing $1.5 \mathrm{~mL}$ of $\mathrm{log}$ phase JM101 growing in $2 X Y T$. This was incubated with vigorous shaking in a Dubnoff Metabolic shaking Waterbath at $37^{\circ} \mathrm{C}$ for $7-8 \mathrm{~h}$. The culture was transferred to a microcentrifuge tube and the cells were pelleted with a 5 min centrifugation. The supernatant was transferred to a clean tube and the centrifugation was repeated a second time. The cell pellet was retained for preparation of RF DNA, and the SS DNA was prepared as described by Schreier and Cortese (1979). The supernatant was transferred to a 
tube containing $0.2 \mathrm{~mL}$ of cold $\mathrm{PEG} / \mathrm{NaCl}$, mixed, and kept at room temperature for $15 \mathrm{~min}$. The phage pellet was collected by a $5 \mathrm{~min}$ centrifugation and the supernatant was aspirated off. A second 3 min centrifugation of the pellet was done and the remaining traces of $\mathrm{PEG} / \mathrm{NaCl}$ were removed by aspiration. The phage pellet was resuspended in $100 \mu \mathrm{L}$ of TEN 250 , then mixed with $50 \mu \mathrm{L}$ of phenol/chloroform $(1: 1)$. The phases were once again separated by centrifugation and the aqueous phase was transferred to a tube containing $50 \mu \mathrm{L}$ of chloroform. After this extraction, $0.25 \mathrm{~mL}$ of ethanol was added to the aqueous phase, and the tube was kept overnight at $-20^{\circ} \mathrm{C}$. The DNA was collected by a 20 min centrifugation, dried at room temperature, and resuspended in 15-25 $\mu \mathrm{L}$ of TE or HPLC water.

\subsubsection{Preparation of RF DNA}

After removing the supernatant in section 3.15.3, RF DNA was prepared from the remaining pellet as described in section 3.8.2.1.

\subsubsection{Preparation and Electrophores is of Sequencing Gels}

\section{Materials}

TBE Running Buffer $(10 \times$ Stock) per liter:

$\begin{array}{rl}108 \mathrm{~g} & \text { Trizma base (Sigma) } \\ 55 \mathrm{~g} & \text { boric acid (Fisher) } \\ 9.3 \mathrm{~g} & \mathrm{Na} 2 \mathrm{EDTA} .2 \mathrm{H}_{2} \mathrm{O} \text { (Sigma) }\end{array}$

(gives a stock of $\mathrm{pH} 8,3$ )

40\% Acrylamide Stock

per $100 \mathrm{~mL}$ :

$38 \mathrm{~g}$ acrylamide (Bio-Rad Laboratories)

$2 \mathrm{~g} \quad$ NN'-methylene bisacrylamide (Sigma)

The solution was filtered and stored in the dark at room temperature.

$5 \times$ TBE Stock: Prepared by diluting the $10 \times$ stock

Sialyzing Solution: $2 \%$ dichloromethylsilane (Aldrich) (V/v) in carbon tetrachloride (MCB)

Ammonium Persulfate Solution: $100 \mathrm{mg}$ of ammonium persulfate (Fisher) dissolved in $1.0 \mathrm{~mL}$ of 
distilled water was freshly prepared each time.

Two $38.5 \times 20 \mathrm{~cm}$ gel plates were thoroughly scrubbed with soap and water, then rinsed with distilled water. One plate was sialyzed on one side and thoroughly rinsed with distilled water. After both plates were clean and dry, two $0.05 \mathrm{~cm}$ spacers were placed between them and the plates were taped in place. For each gel

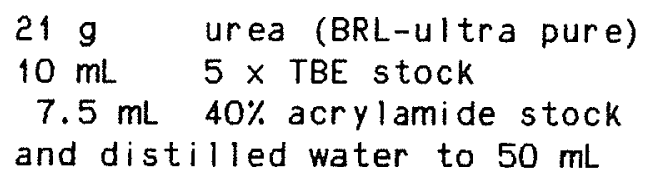

was dissolved at $37^{\circ} \mathrm{C}$ and then allowed to cool to room temperature before adding $50 \mathrm{HL}$ TEMED (BRL-ultrapure) and $0.25 \mathrm{~mL}$ of ammonium persulfate solution. The acrylamide solution was slowly injected between the glass plates with a $50 \mathrm{~mL}$ syringe.

Samples were loaded into wells with BRL "sharkstooth" combs and the gels were electrophoresed at $1200 \mathrm{~V}$ (constant voltage) using $1 \times$ TBE buffer prepared by diluting the $10 \times$ TBE stock. The first part of the sequence was obtained by ending the electrophoresis after the bromophenol blue from the tracking dye reached the bottom (about $1.5 \mathrm{~h}$ ) and sequence beyond that which could be read on this gel was obtained by ending electrophoresis after the xylene cyanol reached the bottom (about $3 \mathrm{~h})$. For sequence between $350-550$ bp the samples were run from $6-11 \mathrm{~h}$. Gels to be run for 6-11 $\mathrm{h}$ were prepared and run in $1 \times$ TBE diluted from a $10 \times$ TBE stock containing $162 \mathrm{~g} \mathrm{Tris,} 27.5 \mathrm{~g}$ boric acid, and $9.5 \mathrm{~g}$ $\mathrm{Na}_{2} \mathrm{EDTA} . \mathrm{H}_{2} \mathrm{O}$ per $\mathrm{liter}$.

\subsubsection{Sequencing and T-Tracking SS Templates} Materials

Klenow Buffer $(10 x): 100 \mathrm{mM}$ Tris-HCL pH 8.0 $50 \mathrm{mM} \mathrm{MgCl} 2$ 


\section{(prepared in deionized distilled $\mathrm{H}_{2} \mathrm{O}$ )}

Klenow Dilution Buffer: $10 \mathrm{mM} \mathrm{Tr}$ is-HCl pH 8.0

(prepared in deionized distilled $\mathrm{H}_{2} \mathrm{O}$ )

Dideoxynucleotide Solutions (Pharmacia sequencing grade): $10 \mathrm{mM}$ stocks were prepared in HPLC grade $\mathrm{H}_{2} \mathrm{O}$ and frozen at $-60^{\circ} \mathrm{C}$.

Working solutions were prepared by diluting the stocks in HPLC grade $\mathrm{H}_{2} \mathrm{O}$ ) to the following concentrations:
$0.1 \mathrm{mM}$ ddATP
$0.1 \mathrm{mM}$ ddCTP
$0.3 \mathrm{mM}$ ddGTP
$0.5 \mathrm{mM}$ ddTTP

Deoxynucleotide Solutions: $10 \mathrm{mM}$ stocks were prepared in $5 \mathrm{mM}$ Tris-HCL PH 7.4 and 0.4 mM EDTA. dNTP's were purchased from Pharmacia.

$0.5 \mathrm{mM}$ working solutions of dCTP, dGTP, and dTTP were prepared from the stocks in HPLC $\mathrm{H}_{2} \mathrm{O}$. The nucleotide mixes were prepared with the nucleotide to be sequenced limiting as follows.

\begin{tabular}{lccccc}
$\begin{array}{l}\text { Nucleotide to } \\
\text { be sequenced }\end{array}$ & $0.5 \mathrm{mM}$ dCTP & $0.5 \mathrm{mM}$ dGTP & $0.5 \mathrm{mM}$ dTTP & $\begin{array}{c}50 \mathrm{mM} \\
\text { Tr is } \mathrm{pH}\end{array}$ \\
\hline $\mathrm{A}^{0}$ & $20 \mu \mathrm{L}$ & $20 \mu \mathrm{L}$ & $20 \mu \mathrm{L}$ & $5 \mu \mathrm{L}$ \\
$\mathrm{C}^{0}$ & $1 \mu \mathrm{L}$ & $20 \mu \mathrm{L}$ & $20 \mu \mathrm{L}$ & $5 \mu \mathrm{L}$ \\
$\mathrm{G}^{\circ}$ & $20 \mu \mathrm{L}$ & $1 \mu \mathrm{L}$ & $20 \mu \mathrm{L}$ & $5 \mu \mathrm{L}$ \\
$T^{0}$ & $20 \mu \mathrm{L}$ & $20 \mu \mathrm{L}$ & $1 \mu \mathrm{L}$ & $5 \mu \mathrm{L}$
\end{tabular}

$\begin{array}{ll}\text { Chase: } & 0.5 \mathrm{mM} \text { dATP } \\ & 0.5 \mathrm{mM} \text { dCTP } \\ & 0.5 \mathrm{mM} \text { dGTP } \\ & 0.5 \mathrm{mM} \text { dTTP } \\ & \text { prepared in HPLC grade } \mathrm{H}_{2} \mathrm{O}\end{array}$

[ $\left.\alpha^{32} p\right]$ dATP for Sequencing: High specific activity 32p-labelled dATP was purchased from NEN. Before use, the label was diluted with $0.125 \mathrm{mM}$ cold dATP ( $1 \mu \mathrm{L}$ for every $4 \mu \mathrm{L}$ of label) to give a specific activity of $300 \mathrm{ci} / \mathrm{nM}$.

M13 Primer: The 17 base long universal sequencing primer was purchased from Regional DNA Synthesis Laboratory, University of Calgary. The primer was dissolved in HPLC grade $\mathrm{H}_{2} \mathrm{O}$ at a concentration of $2 \mathrm{ng} / \mu \mathrm{L}$.

Formamide Dye: $10 \mathrm{~mL}$ of formamide was stirred gently with $0.5 \mathrm{~g}$ Amber liteTM MB1 for $30 \mathrm{~min}$. The Amberlite was removed by filtration and the formamide was mixed with $0.03 \mathrm{~g}$ xylene cyanol FF, $0.03 \mathrm{~g}$ bromophenol blue, and $0.75 \mathrm{~g} \mathrm{Na} 2 \mathrm{EDTA} \cdot 2 \mathrm{H}_{2} \mathrm{O}$.

\subsubsection{Reactions for T-Tracking 10 Clones}

To anneal the primer to the template, $2 \mu \mathrm{L}$ of ss DNA was mixed with a $2 \mu \mathrm{L}$ aliquot of primer $\operatorname{mix}(4 \mu \mathrm{L} M 13 \mathrm{primer}, 6 \mu \mathrm{L} 10 \times \mathrm{Klenow}$ buffer, 
$12 \mathrm{HL} \mathrm{HPLC}$ grade $\mathrm{H}_{2} \mathrm{O}$ ) and placed at $65^{\circ} \mathrm{C}$ for $5 \mathrm{~min}$. The tubes were then allowed to cool for 20 min at room temperature. A T-reaction mixture was prepared from $8 \mu \mathrm{L}$ ddTTP, $8 \mu \mathrm{L}$ dTTP, $4 \mu \mathrm{L}\left[\alpha^{32 P}\right] \mathrm{dATP}$, and $1 \mu$ Lof Klenow (DNA Polymerase 1 Klenow Fragment, Pharmacia). Two $\mu \mathrm{L}$ was added to each tube of primed template. After a $15 \mathrm{~min}$ incubation at $42^{\circ} \mathrm{C}, 1.5 \mu \mathrm{L}$ of chase was added to each tube and the incubation was continued for another $15 \mathrm{~min}$. The tubes were removed from the waterbath, $2 \mu \mathrm{L}$ of formamide dye was added, and the tubes were centrifuged a few seconds in a Beckman Microfuge 11 . The tubes were then boiled $3 \mathrm{~min}$ and 2.5 to $3.5 \mu \mathrm{L}$ was loaded on the gel.

\subsubsection{Reactions for Sequencing SS Templates}

For samples to be sequenced $7 \mu \mathrm{L}$ of DNA was mixed with $1.5 \mu \mathrm{L}$ of $10 \times$ Klenow buffer, and $2 \mu \mathrm{L}$ of primer. The samples were placed at $65^{\circ} \mathrm{C}$ for $5 \mathrm{~min}$ and then allowed to cool at room temperature for $20 \mathrm{~min}$. For each clone to be sequenced $A, C, G$, and $T$ reaction tubes containing $1 \mu L$ of the appropriate ddNTP, $1 \mu L$ of the corresponding dNTP solution and $0.5 \mathrm{~mL}$ of $\left[\alpha^{32} \mathrm{P}\right] \mathrm{dATP}$ were prepared (ie: $1 \mu \mathrm{L}$ ddATP and $1 \mu \mathrm{L} \mathrm{A}^{0}$ solution= A reaction). Two $\mu L$ of the annealed primer-template was added to each of the four reaction tubes. Two $\mu \mathrm{L}$ of diluted klenow. ( $1 \mathrm{HL}$ in $24 \mu \mathrm{L}$ of $\mathrm{Klenow}$ dilution buffer) was then added to each tube. After a $15 \mathrm{~min}$ incubation at $42^{\circ} \mathrm{C}, 2 \mu \mathrm{L}$ of chase was added and the incubation was continued for $30 \mathrm{~min}$. Four $\mu \mathrm{L}$ of formamide dye was added, the tubes were centrifuged, and then boiled 3 min before loading the gel.

\subsubsection{Preparation for and Autoradiography of Sequencing Gels}

After the samples had been electrophoresed as far as required, the taped plates were removed from the apparatus. The tape was removed and 
the gel plates were carefully pried apart with a spatula, leaving the gel on the non-sialyzed plate surface. The gel was then transferred on the plate to a $5 \%$ methanol/5\% acetic acid bath and soaked for at least 20 min. The gel was then blotted with $K$ im wipes to remove excess liquid and transferred to whatman 3MM paper. The partially dried gel readily stuck to the paper and peeled away from the glass plate. Using a Bio-Rad Model $483 \mathrm{slab}$ Dryer, the gel was dried under vacuum for 1 h at $80^{\circ} \mathrm{C}$. The dried gel was then placed on Kodak X-Omat AR X-ray film and exposure was allowed to proceed for $18 \mathrm{~h}$ at room temperature before developing the film as described in section 3.11.3.

\subsubsection{Interpretation of the DNA Sequence}

Gels were read on a light box keeping the following rules in mind. In sequences of more than one $c$ residue, the first $c$ is much weaker in intensity than the second $c$. Runs of G's give a similar pattern to C's when preceded by a $T$ residue. In runs of consecutive A residues, the first A will be the most intense with the rest of equal or gradually decreasing intensity. Runs of $T$ residues following a $C$ residue show a similar pattern. These and other nints on the interpretation of DNA sequence are described by Hindley and Staden (1983).

Analysis of the DNA sequence was done both manually and by computer. The computer software package, Microgenie (Beckman) was used to predict the amino acid sequence, calculate the protein molecular weight, determine the codon usage, determine the amino acid content, compare sequences to each other and with the data bank, and predict the hydrophilicity of the amino acid residues. 
RESULTS 


\subsection{RESULTS}

\section{Genetic Mapping of Transposon Tn fo Catalase Mutants}

\subsubsection{Isolation, Characterization, and Mapping of katE12: : Tn 10 and katF13: : Tn80}

Transposon Tn10 insertions in MP180 were isolated by spreading cells infected by $\lambda 561$ on LBT plates and incubating them overnight at $42^{\circ} \mathrm{C}$. Approximately 10000 colonies were screened for catalase activity by the colony $\mathrm{H}_{2} \mathrm{O}_{2}$ drop test. Two colonies with lower catalase levels were picked and stored as UM120 and UM122. Both mutants had low stationary phase catalase leveis when assayed on agar plates, but the stationary phase oxygraph values of UM120 and UM122 were similar to the parental strain (See Table 3 for oxygraph values). High stationary phase oxygraph values had been previously observed for the HPII mutant, UM181 by Loewen and Triggs (1984). The high stationary phase oxygraph values in the absence of $\mathrm{HP} / \mathrm{I}$ may result because the $\mathrm{H}_{2} \mathrm{O}_{2}$ concentrations become elevated in stationary phase, inducing HPI. On agar plates, the absence of aeration prevents the $\mathrm{H}_{2} \mathrm{O}_{2}$ from accumulating to a concentration high enough to induce HPI. UM120 and UM122 were ascorbate inducible like their parent, MP180 (see Table 4). These characteristics were typical of HPII mutants that had been previously isolated.

Cell free extracts from stationary phase cultures of UM120 and UM122 were electrophoresed on polyacrylamide gels, then stained for catalase and peroxidase activity. The results are illustrated in Figure 2. In both the UM120 and UM122 extracts, the slow running HPII band was absent, confirming that the mutations in these strains were 
Table 3. Catalase levels in Tnlo generated catalase mutants and their parents

\begin{tabular}{|c|c|c|c|c|}
\hline \multirow[b]{2}{*}{ Strain } & \multicolumn{2}{|c|}{$\begin{array}{l}\text { Catalase Activity } \\
\text { Log Phase }\end{array}$} & \multicolumn{2}{|c|}{$\begin{array}{l}\text { [dry cell wt }]) \\
\text { Stationary Phase }\end{array}$} \\
\hline & $1.5 \mathrm{~mm}^{\mathrm{a}}$ & $60 \mathrm{~mm}^{\mathrm{b}}$ & $1.5 \mathrm{mM}$ & $60 \mathrm{mM}$ \\
\hline MP180 & 4.2 & 16.8 & 9.6 & 39.9 \\
\hline UM120 (katE12: : Tn 10) & 3.7 & 15.5 & 7.8 & 24.6 \\
\hline UM122 (KatF13: :Tn 10) & 6.5 & 21.2 & 11.2 & 49.3 \\
\hline UM202 (katG17: :Tn 10) & NDC & 3.2 & 2.7 & 22.8 \\
\hline UM178 (KatE1) & 1.5 & $N A^{d}$ & NA & NA \\
\hline UM196 (katE1 kat617: :Tn 10) & ND & NA & NA & NA \\
\hline $\mathrm{CSH} 57 \mathrm{a}$ & 3.9 & 16.3 & 8.3 & 34.2 \\
\hline UM197 (katG17: :Tn 10) & ND & ND & ND & 13.7 \\
\hline
\end{tabular}

a concentration of $\mathrm{H}_{2} \mathrm{O}_{2}$ in assay was $1.5 \mathrm{mM}$

$b$ concentration of $\mathrm{H}_{2} \mathrm{O}_{2}$ in assay was $60 \mathrm{mM}$

c not detectable

d not assayed 
Table 4. Effect of ascorbate on catalase levels of var ious strains

\begin{tabular}{|c|c|c|c|c|c|c|}
\hline Strain & $\begin{array}{l}\text { Catalase } \\
-10\end{array}$ & $\begin{array}{l}(U / \mathrm{mg} \\
-5\end{array}$ & $\begin{array}{l}{[d r y \text { cell }} \\
+10\end{array}$ & $\begin{array}{l}w t])^{a} \\
+15\end{array}$ & $\begin{array}{l}\text { at time } \\
+20\end{array}$ & $\begin{array}{c}(\min )^{b} \\
+30\end{array}$ \\
\hline MP 180 & 4.2 & 3.7 & 15.1 & & 21.0 & \\
\hline UM120(katE12: :Tn 10) & 3.5 & 3.7 & 12.3 & & & 27.3 \\
\hline UM122(katF13: :Tn 10) & 4.9 & 4.9 & 15.2 & & & 17.1 \\
\hline UM178 (katE1) & 1.5 & 2.3 & & 7.7 & & 7.9 \\
\hline UM196(katE1 katG17::Tn10) & ) $N D^{C}$ & ND & & ND & & ND \\
\hline CSH57a & 2.5 & 2.4 & & 6.1 & & 8.6 \\
\hline UM197(katG17: :Tn 10) & 0.5 & ND & & ND & & ND \\
\hline
\end{tabular}

$\mathrm{H}_{2} \mathrm{O}_{2}$ concentration in assay was $1.5 \mathrm{mM}$

b Ascorbate was added at o time

c not detectable 
Figure 2. Visualization of catalase and peroxidase in crude extracts of MP180 and the transposon Tn 10 derivatives UM120, UM122, and UM202. Lanes $A, C, E$, and $G$ were stained for catalase activity and lanes $B, D, F$, and $H$ were stained for peroxidase activity. The following samples were run: $A$ and $B$ from MP180, $540 \mu g$ protein; $C$ and $D$ from UM120, $535 \mathrm{\mu g}$ protein; $E$ and $F$ from UM122, $545 \mathrm{\mu g}$ protein; $G$ and $H$ from UM202, $560 \mu g$ protein (Loewen et al., 1985a). 

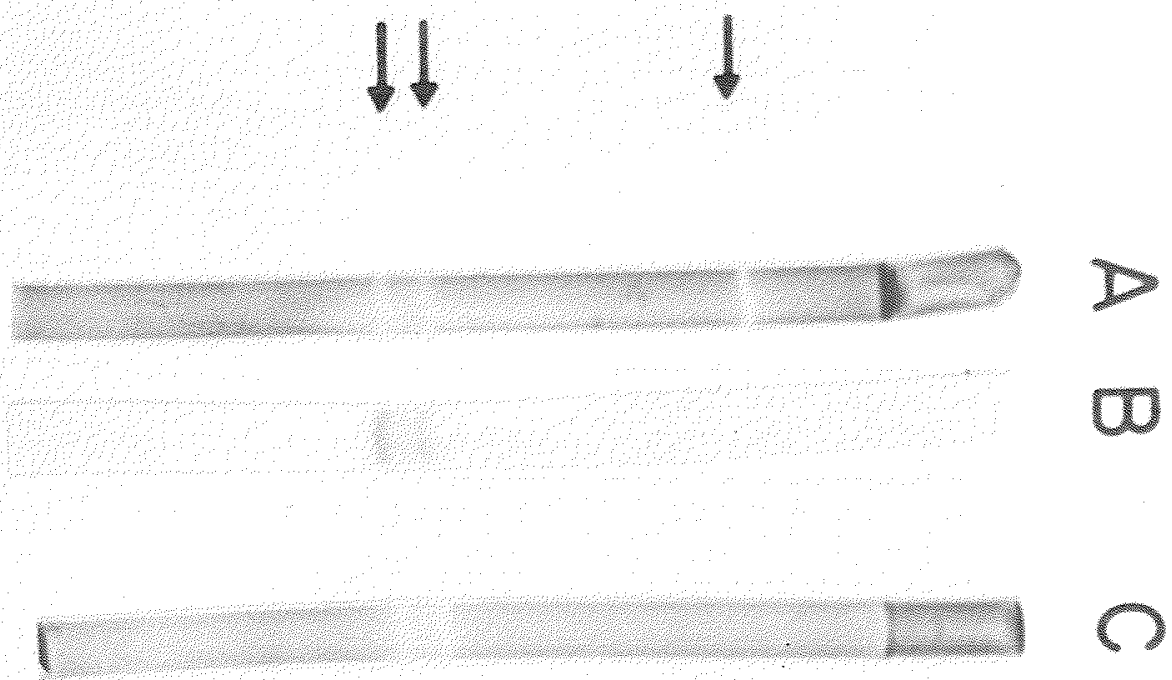

.)

(5)

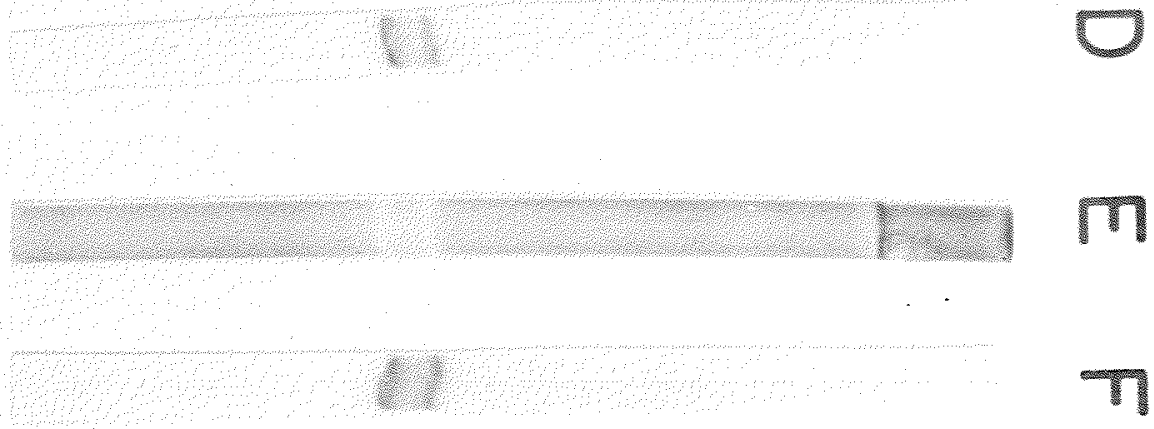

7

7

G

I

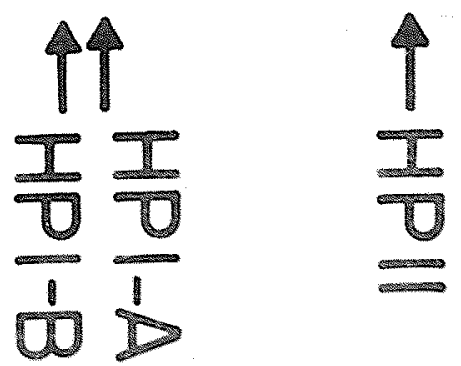


affecting the HPII catalase.

Prior to mapping the transposon insertions, the stability of the mutations was tested. No catalase positive revertants of either strain were found in $1000 \mathrm{Tc}^{R}$ colonies. Attempts to select revertants out of the population in low levels of $\mathrm{H}_{2} \mathrm{O}_{2}$ or on Maloy $\mathrm{Tc}^{\mathrm{S}}$ selection plates were unsuccessful. The mutations were stable and therefore suitable for mapping by interrupted mating and P1 transduction. Transposons have been shown to be suitable for the mapping and cloning of genes in several organisms (DeBruijn and Lupski, 1984).

The general locations of the Tnfo insertions were found by interrupted mating, then specifically located by PI transduction. Interrupted matings between UM12O or UM122 and the recipient, CSH57a (rpsL) were done and samples were spread on LBST plates to select $T n 10$ containing $\left(T C^{R}\right)$ recipient cells. The time of entry data were plotted (Figure 3) and the Tn 10 in UM120 was found to enter at approximately 39 min while the Tn10 of UM122 entered at about $63 \mathrm{~min}$. Since the $T$ in 10 of UM122 entered relatively late, the precision of the time of entry data dropped significantly (Miller, 1972). The loss of precision is evident from the slower rate of increase of $\mathrm{TC}^{\mathrm{R}}$ recombinants during the mating. These loci appeared to be the same loci that had been identified by NG mutagenesis and mapped as katE at $37.8 \mathrm{~min}$ and katf at $59 \mathrm{~min}$ (Loewen, 1984; Loewen and Triggs, 1984). P1 transductions were then used to look for the linkage of the $T n 10\left(T c^{R}\right)$ mutations with loci previously found to cotransduce with kate or katF. The kat12::Tn10 (UM120) locus cotransduced with the temperature sensitive locus, phes, $62 \%$ of the time (see Table 5), which converted to a 0.3 min separation, agreeing well 
Figure 3. Determination of time of entry for katE12: :Tn 10 and katF13: :Tn 10. TCl recombinants from the UM120/CSH57a ( $\square$ ), and the UM122/CSH57a (o) matings were enumerated by taking samples at various time intervals, vortexing them, and plating aliquots on LBST plates. The best straight line through each set of data points above the background level was determined by linear regression. The line was extrapolated to the $X$ axis to give the approximate time of entry for the two genes, katE and katf. 


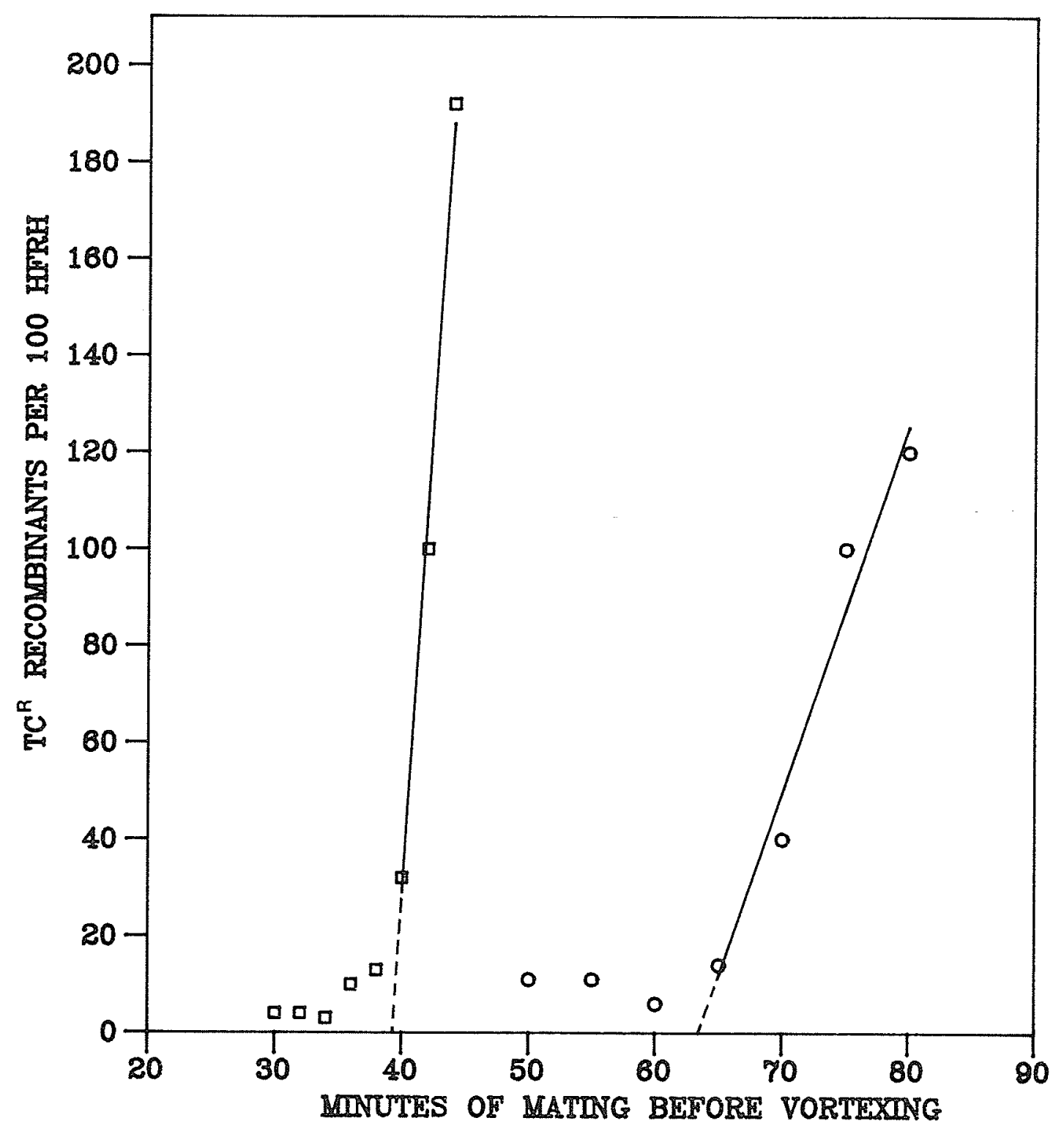


Table 5. Mapping of katE12:: Tn 10 and RatF 13::Tn 10 by P1 transduction

\begin{tabular}{|c|c|c|c|c|c|c|}
\hline \multirow[b]{2}{*}{ Donor } & \multirow[b]{2}{*}{ Recipient } & \multirow{2}{*}{$\begin{array}{l}\text { Selected } \\
\text { Marker }\end{array}$} & \multicolumn{2}{|c|}{ Unselected } & \multicolumn{2}{|c|}{ Marker } \\
\hline & & & Class & No. & $(\%)$ & $\min ^{a}$ \\
\hline $\begin{array}{l}\text { UM120 } \\
\text { (katE 12: : Tn 10) }\end{array}$ & $\begin{array}{c}4913 \\
\text { (phes) }\end{array}$ & $T c^{R}$ & $\begin{array}{l}\text { phest } \\
\text { phes }\end{array}$ & $\begin{array}{r}148 \\
92\end{array}$ & $\begin{array}{l}(62) \\
(38)\end{array}$ & 0.3 \\
\hline $\begin{array}{l}\text { UM122 } \\
\text { (katF13: :Tn 10) }\end{array}$ & $\begin{array}{l}\text { JF627 } \\
(p y r G)\end{array}$ & $T c^{R}$ & $\begin{array}{l}\text { pyrG } \\
\text { pyrG }\end{array}$ & $\begin{array}{r}21 \\
163\end{array}$ & $\begin{array}{l}(11) \\
(89)\end{array}$ & 1.0 \\
\hline $\begin{array}{l}\text { UMt22 } \\
(\text { katF } 3:: \operatorname{Tn} 10)\end{array}$ & $\begin{array}{l}\text { JF627 } \\
(p y r G)\end{array}$ & pyrG ${ }^{+}$ & $\begin{array}{l}T c^{R} \\
T c^{S}\end{array}$ & $\begin{array}{r}6 \\
234\end{array}$ & $\begin{array}{l}(3) \\
(97)\end{array}$ & 1.4 \\
\hline $\begin{array}{l}\text { UM122 } \\
\text { (katF13: :Tn 10) }\end{array}$ & $\begin{array}{l}J M 96 \\
(\text { cysh) }\end{array}$ & $T c^{R}$ & $\begin{array}{l}\text { Cysh } \\
\text { cysh }\end{array}$ & $\begin{array}{l}185 \\
175\end{array}$ & $\begin{array}{l}(51) \\
(49)\end{array}$ & 0.4 \\
\hline $\begin{array}{l}\text { UM122 } \\
\text { (katF13: :Tn1O) }\end{array}$ & $\begin{array}{c}J M 96 \\
(\text { CysH })\end{array}$ & $\mathrm{Cysh}^{+}$ & $\begin{array}{l}T c^{R} \\
T c^{S}\end{array}$ & $\begin{array}{r}95 \\
265\end{array}$ & $\begin{array}{l}(26) \\
(74)\end{array}$ & 0.7 \\
\hline
\end{tabular}


with other mapping data for katE (Loewen, 1984). The kat13: :Tn 10 (UM12.2) mutation cotransduced with pyrG and cysH at average frequencies of $7 \%(1.2 \mathrm{~min})$ and $38 \%(0.55 \mathrm{~min})$ respectively (see Table 5), mapping katF13: :Tn 10 to approximately $58.9 \mathrm{~min}$. The data for katF13: $\operatorname{Tn} 10 \mathrm{fit}$ well with other data mapping katF (Loewen and Triggs, 1984). The general locations of katE and katf on the E. coli chromosome are illustrated in Figure 4 .

\subsubsection{Isolation, Characterization, and Mapping of katG17:: Tn 10}

katG mutants could not be isolated directly in MP180 because the catalase levels of katG mutants on agar plates are almost the same as wild type levels. Consequently, a katE katG ${ }^{+}$strain, UM178, was mutagenized with Tn10. After screening more than 12000 colonies, a Tn10 mutant lower in catalase (kat17::Tn 10) was isolated and stored as UM196. To allow certain experiments to be performed in katE ${ }^{+}$strains the mutation was transferred into MP180 and CSH57a by $P 1$ transduction and these strains were stored as UM202 and UM197 respectively.

UM196 (katE kat17::Tn 10) had almost no catalase activity on agar plates and no assayable catalase in the oxygraph. UM202, which was katE kat17: :Tn 10, had normal catalase levels on the agar plate but little assayable catalase during log phase. During stationary phase catalase was present (see Table 3). Strains carrying the kat17::Tn 10 mutation were not inducible with ascorbate (see Table 4). The properties of these mutants led to the understanding of the independent induction of catalases HPI and MPII (Loewen et al., 1985a).

Cell free extracts of stationary phase UM202 were electrophoresed and stained for catalase and peroxidase activities. As shown in Figure 2 this mutant lacked the faster running HPI A and B doublet in gels 
Figure 4. a) Genetic map of $E$. coli $K 12$ based on $100 \mathrm{~min}$. The locations of katE, katf, and katG as well as some other relevant markers are shown. The arrows indicate the origin and direction of transfer of the Hfr strains used in this study (Bachmann, 1983). b) Genetic map orienting katG relative to other nearby markers. met $B$ acted as a reference point for the placement of katG (Loewen et al., 1985b). 

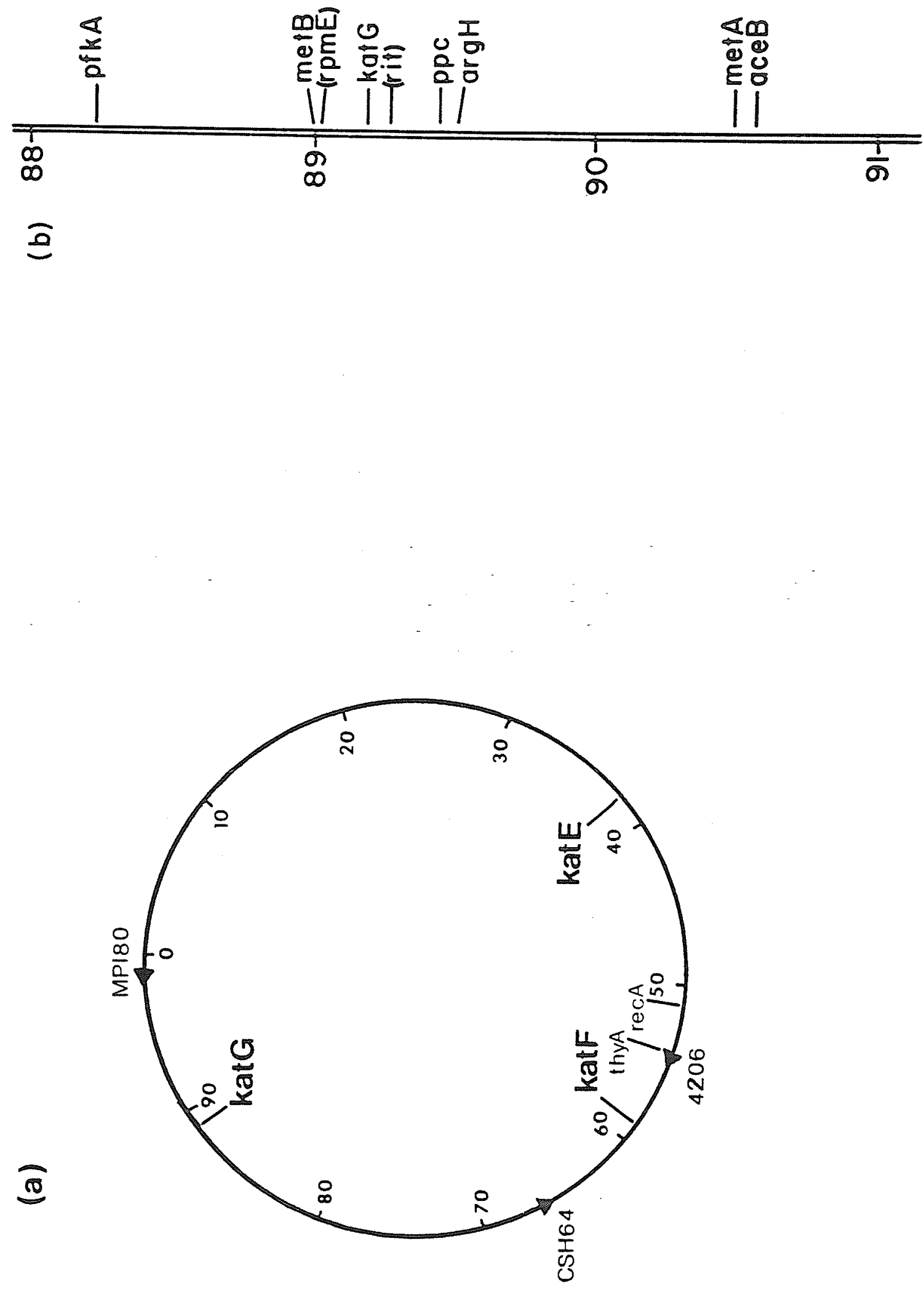
stained for both catalase and peroxidase.

The characteristics of the kat17: :Tn 10 mutation (1ittle assayable catalase during log phase growth and no catalase induction by ascorbate) suggested that it was a mutant of the kat 6 gene which mapped around 90 min. P1 transductions using UM196 as the kat17: :Tn10 donor showed that this locus was katG, and these data, in combination with mapping data from NG mutants (Loewen et al., 1985b), mapped kat $G$ to 89.2 min on the $E$. coli chromosome (see cotransduction frequencies and equivalent map units in Table 6). The linkage between argH and the Tn10 was found to vary depending on the selected marker, $\mathrm{Tc}^{R}$ or $\operatorname{argh}^{+}$. A second set of transductions was done with another argH strain, PA309 but the frequencies were still fairly inconsistent, suggesting that this was somehow a consequence of this particular selection system. For instance, one sequence may recombine more frequently than the other. The general location of the gene on the chromosome is shown in Figure 4 and the more precise location of katG is illustrated beside it. The cotransduction frequencies placed the genes in the order metB-katG-ppc-argH. The other markers, rpmE, coding for a ribosomal protein, and rit, coding for a protein that affects the thermolability of the $50 s$ ribosomal subunit, were placed by comparing our data to those for rpmE (Dabbs, 1981) and rit (Ono, 1978) (Loewen et al., 1985b).

\subsection{Isolation of Transformable Catalase Mutants}

\subsubsection{Isolation of Catalase Mutants by NG Mutagenes is}

Catalase mutants had been previously isolated by NG mutagenes is of CSH7 and CSH57a (Loewen, 1984; Loewen and Triggs, 1985; Loewen et al., 1985b), but these strains had very low transformation efficiencies. 
Table 6. Mapping of kat617::Tn10 by PI transduction

\begin{tabular}{|c|c|c|c|c|c|c|}
\hline \multirow[b]{2}{*}{ Donor } & \multirow[b]{2}{*}{ Recipient } & \multirow{2}{*}{$\begin{array}{l}\text { Selected } \\
\text { Marker }\end{array}$} & \multicolumn{2}{|c|}{ Unselected } & \multicolumn{2}{|c|}{ Marker } \\
\hline & & & Class & No. & $(\%)$ & $\min ^{a}$ \\
\hline $\begin{array}{l}\text { UM196 } \\
\text { (katG17: :Tn 10) }\end{array}$ & $\begin{array}{c}5128 \\
(m e t B)\end{array}$ & $T c^{R}$ & $\begin{array}{l}\operatorname{me} t B^{+} \\
\text {met } B\end{array}$ & $\begin{array}{r}188 \\
52\end{array}$ & $\begin{array}{l}(78) \\
(22)\end{array}$ & 0.16 \\
\hline $\begin{array}{l}\text { UM196 } \\
(\text { katG17: :Tn 10) }\end{array}$ & $\begin{array}{c}5128 \\
(m e t B)\end{array}$ & $m e t B^{+}$ & $\begin{array}{l}T c^{R} \\
T c^{S}\end{array}$ & $\begin{array}{r}196 \\
44\end{array}$ & $\begin{array}{l}(82) \\
(18)\end{array}$ & 0.13 \\
\hline $\begin{array}{l}\text { UM196 } \\
(\text { katG17: :Tn 10) }\end{array}$ & $\begin{array}{c}6374 \\
(\text { argh) }\end{array}$ & $T^{R}{ }^{R}$ & $\begin{array}{l}\operatorname{argH^{+}} \\
\arg H\end{array}$ & $\begin{array}{r}67 \\
170\end{array}$ & $\begin{array}{l}(28) \\
(72)\end{array}$ & 0.7 \\
\hline $\begin{array}{l}\text { UM196 } \\
(k a t 617:: \operatorname{Tn} 10)\end{array}$ & $\begin{array}{c}6374 \\
(a r g H)\end{array}$ & $\arg H^{+}$ & $\begin{array}{l}T c^{R} \\
T c^{S}\end{array}$ & $\begin{array}{l}107 \\
133\end{array}$ & $\begin{array}{l}(45) \\
(55)\end{array}$ & 0.23 \\
\hline $\begin{array}{l}\text { UM196 } \\
(\text { KatG17: }: \operatorname{Tn} 10)\end{array}$ & $\begin{array}{r}5236 \\
(p p c)\end{array}$ & $T c^{R}$ & $\begin{array}{l}p p c^{+} \\
p p c\end{array}$ & $\begin{array}{r}155 \\
85\end{array}$ & $\begin{array}{l}(65) \\
(35)\end{array}$ & 0.27 \\
\hline $\begin{array}{l}\text { UM196 } \\
\text { (katG17: :Tn 10) }\end{array}$ & $\begin{array}{l}5236 \\
(P P C)\end{array}$ & $p p c^{+}$ & $\begin{array}{l}T c^{R} \\
T c^{S}\end{array}$ & $\begin{array}{r}173 \\
67\end{array}$ & $\begin{array}{l}(72) \\
(28)\end{array}$ & 0.21 \\
\hline $\begin{array}{l}\text { UM196 } \\
\text { (katG17: : Tn 10) }\end{array}$ & $\begin{array}{l}\text { PA309 } \\
\text { (argH) }\end{array}$ & $T c^{R}$ & $\begin{array}{l}\operatorname{argh} H^{+} \\
\operatorname{argH}\end{array}$ & $\begin{array}{l}24 \\
55\end{array}$ & $\begin{array}{l}(30) \\
(70)\end{array}$ & 0.66 \\
\hline $\begin{array}{l}\text { UM196 } \\
\text { (katG17: :Tn 10) }\end{array}$ & $\begin{array}{l}\text { PA309 } \\
\text { (argH) }\end{array}$ & $\arg H^{+}$ & $\begin{array}{l}T c^{R} \\
T c^{S}\end{array}$ & $\begin{array}{l}117 \\
123\end{array}$ & $\begin{array}{l}(49) \\
(51)\end{array}$ & 0.42 \\
\hline
\end{tabular}


HB101, a readily transformable E. colik12 strain was mutagenized with NG and two mutants that were lower in catalase, UM68 and UM69, were isolated. Unfortunately, the background catalase levels were still so high that after transformation with the catalase carrying plasmid pLC36-19, pLC36-19 containing colonies could not be differentiated from non-plasmid bearing colonies. UM69 was further mutagenized with NG producing UM123, a strain with lower catalase than UM69 but still not completely negative. UM123 had variable catalase levels depending on the media content and often the background levels were too high to allow the differentiation of pLC36-19 containing colonies and non-plasmid harbouring colonies.

The NG mutagenes is of HB101 was repeated and three mutants lower in catalase, UM228, UM229, and UM230 were isolated. UM228 had the lowest catalase levels on agar plates although it had equal or higher catalase levels in the oxygraph (see Table 7). Because of its low catalase activity on agar plates, UM228 was chosen for the transformation of and screening for plasmid encoded catalase. UM228 was found to be readily transformable and colonies containing catalase bearing plasmids (PA30 and $\mathrm{DE6}$ ) were obvious on the agar plate and in the oxygraph (see Table 7). A genetic characterization of the catalase mutations was not possible because the strain was recA, preventing the efficient recombination required for mapping. Extracts of UM228 contained only HPI which was still ascorbate inducible, (see Table 8 ), suggesting that the regulation of HPI had not been affected.

\subsubsection{Construction of UM262}

As noted above, all of the transformable catalase mutants available were recA which prevented mapping by interrupted mating or P1 trans- 
Table 7. Catalase activities of nitrosoguanidine mutants

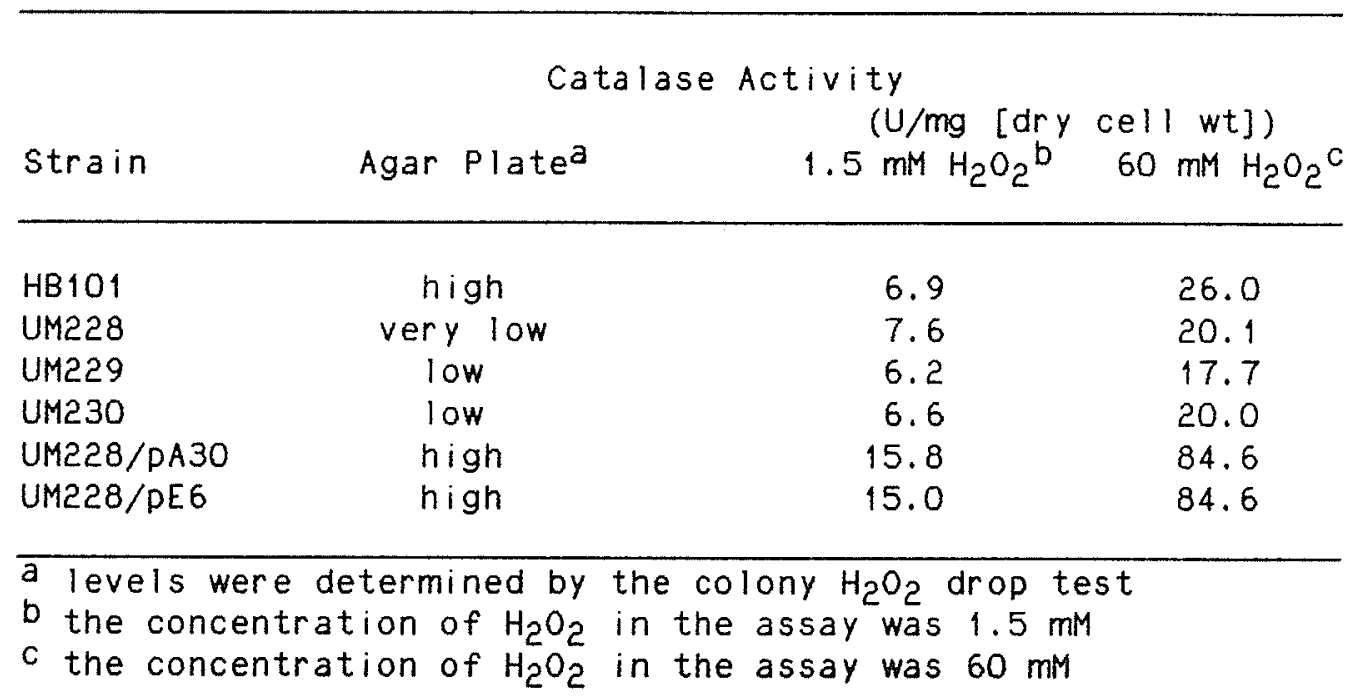


Table 8. Effect of ascorbate on catalase levels of HB101 and UM228

\begin{tabular}{|c|c|c|c|c|}
\hline Strain & $\begin{array}{c}\text { Catalase (U/mg } \\
-10\end{array}$ & ${ }_{-5}^{[d r y}$ cel] & $\begin{array}{l}w t])^{a} a t \\
+15\end{array}$ & $\begin{array}{l}\text { time } \min b \\
+30\end{array}$ \\
\hline HB101 & 2.4 & 2.5 & 7.4 & 9.0 \\
\hline UM228 & 2.7 & 2.8 & 5.0 & 7.2 \\
\hline
\end{tabular}


duction. Furthermore, one NG mutant, UM123, was found to contain a suppressor of catalase activity, reinforcing the need for catalase mutants of known genotype to be used in the cloning of catalase genes.

The recAt parent of HB101, RR1, was used to construct transformable catalase mutants of known genotype. The katG17: Tn 10 locus from UM196 was transduced into RR1 by selecting for $T C^{R}$ colonies. The kat617: Tn 10 derivative of RR1 was plated on $10 \mu \mathrm{g} / \mathrm{mL}$ of trimethoprim to select out a thyA mutant which was stored as UM163. Cultures of the thyA mutant were always supplemented with $100 \mu \mathrm{g} / \mathrm{mL}$ thymine (Miller, 1972) to allow growth. UM163 was mated with 4206 (a recA Hfr with its origin of transfer at $55 \mathrm{~min}$, [Miller, 1972]) and after $10 \mathrm{~min}$ of mating, samples were plated on M9 agar plates lacking thymine to select for thy ${ }^{+}$cells. Since recA (51 min) was close to thy (54.8 $\mathrm{min}$ ) (see Figure 4 ), a large proportion of the thys recombinants were also recA. Cells were then streaked in duplicate onto LB plates and one was exposed to a UV light (Mineralight 115V) for $15 \mathrm{sec}$ at a $15 \mathrm{~cm}$ distance to screen for recA cells. After an overnight incubation in the dark, cells that grew poorly were picked and rechecked in the same way but with a recAt control. A strain that was recA (grew poorly or not at all after the UV irradiation) and kat617::Tn10 was stored as UM262. Other mutant markers of RR1 were checked after each step to make sure the strain retained the original genotype.

\subsection{Restriction Mapping of pLC36-19}

As described in section 2.11, the clarke and Carbon plasmid, pLC36-19 carries the structural gene for HPI. This $25.5 \mathrm{~kb}$ plasmid contained a $19.2 \mathrm{~kb}$ insert of $E$. Coli genomic DNA in a $6.3 \mathrm{~kb}$ Colel 
vector (Loewen et al., 1983). The plasmid was mapped with single and double restriction enzyme digests. The number of restriction sites in a single enzyme digest equalled the number of fragments generated, and in a double digest, the total number of restriction enzyme sites or fragments was equal to the sum of the number of restriction enzyme sites or fragments from the two single enzyme digests.

The sizes of the restriction enzyme fragments generated from pLC36-19 are given in Table 9. These fragments were used to map pLC36-19 by comparing the fragments generated in double digests with the fragments generated from a single enzyme digest. Fragments from a single enzyme digest which disappeared in the double digest must be cut by the second enzyme. The resulting fragments could be identified by adding a combination of the new fragments up to the same size as the original fragment. In cases where two fragments of the same size were generated from a digest, the double band was identified because it appeared orighter than adjacent bands. Fragments larger than 600 bp were usually sized on agarose gels and fragments smaller than 600 bp were normally sized on acrylamide gels. Fragments larger than the largest standard band from Hindlll restricted $\lambda$ DNA $(23.7 \mathrm{~kb})$ could not be sized accurately and are represented by $>23700 \mathrm{bp}$. Subsequent restriction maps in this thesis were generated in a similar manner. Fragments believed to originate from the vector were confirmed by restricting colEl DNA (see Table 10).

This approach was used to map sites for 14 restriction enzymes in PCL36-19 for a total of 57 sites. The final map is shown in Figure 5 . The locations of some of the small Pvull fragments were found by digesting DNA isolated from the two largest Aval bands which were 
Table 9. Restriction enzyme fragments obtained by digestion of pLC36-19

\begin{tabular}{|c|c|c|}
\hline Enzyme & Fragment size (bp) & Sum $(b p)$ \\
\hline$C l a \mid$ & $9870,8580,7080$ & 25530 \\
\hline Aval & $12600,10040,2730$ & 25370 \\
\hline$B a m+1$ & $>23700$ & - \\
\hline$B a l 1$ & $16010,9220,170,160$ & 25560 \\
\hline ECORI & $>23700,380$ & - \\
\hline Hincll & $7900,7050,5200,2100,1800,1350,340,100,90$ & 25930 \\
\hline Hind I I & 21920,3640 & 25560 \\
\hline Hpal & $14500,8950,2400,(100)^{a}$ & 25650 \\
\hline Pstl & $17260,7010,1080,410$ & 25760 \\
\hline Pvull & $\begin{array}{l}7860,6150,3600,3460,1170,1150,650,480,380, \\
370\end{array}$ & \\
\hline Smal & 12700,12700 & 25400 \\
\hline Sall & $>23700$ & - \\
\hline ECORV & $8100,6060,4440,3360,1370,920,730,710$ & 25690 \\
\hline$S p h l$ & $10400,7550,6190,1380,350,200,100$ & 26170 \\
\hline ECoR1-Pst1 & $12630,7010,4530,1080,410,380$ & 26040 \\
\hline EcoR1-Hindl II & $21920,3450,260$ & 25630 \\
\hline ECOR1-BamHI & $>23700,760,380$ & - \\
\hline EcoR1-Smal & $12700,6350,6040,380$ & 25470 \\
\hline Hind || $1-P s t \mid$ & $12210,7010,3640,1080,1150,410$ & 25500 \\
\hline$H i n d|I|-S a \|$ & $21000,3640,1010$ & 25650 \\
\hline Hind। ||-BamH| & $21920,2550,1050$ & 25520 \\
\hline Hpal-Pstl & $12800,5400,2100,1900,1550,1080,410,(100)$ & 25340 \\
\hline Hpal-Smal & $7580,7080,5370,3180,2100,(100)$ & 25410 \\
\hline Hpal-HindIII & $13950,8080,2100,950,750,(100)$ & 25930 \\
\hline Hinc I I-BamHI & $\begin{array}{l}7900,7050,5200,1800,1650,1350,340,300,(100, \\
90)\end{array}$ & 25780 \\
\hline$H$ Hinc $|\mathrm{I}-E \operatorname{CoR}|$ & $7900,7050,5200,2100,1800,1060,330,300,(100)$ & 25840 \\
\hline $\operatorname{Hinc}\left|1-P_{s} t\right|$ & $\begin{array}{l}6210,5500,5200,2100,1800,1550,1350,1080,410, \\
340,(100,90)\end{array}$ & 25730 \\
\hline$H i n c||-B a||$ & $\begin{array}{l}7900,5200,4700,2350,2100,1800,1270,160,(100, \\
90)\end{array}$ & 25670 \\
\hline Ball-Smal & $10100,6560,5600,2910,170,160$ & 25500 \\
\hline$B a|1-P s t|$ & $12750,4620,3650,3150,1080,410,170,160$ & 25990 \\
\hline Ball-Hindlll & $15900,6010,3300,170,160$ & 25540 \\
\hline BamHI-Pstl & $13550,7010,3750,1080,410$ & 25800 \\
\hline Aval-Pstl & $11020,7010,3120,2730,1080,410$ & 25370 \\
\hline Aval-Ball & $7320,6820,5870,3120,2730,170,160$ & 26190 \\
\hline$P v u \mid 1-P 5 t 1$ & $\begin{array}{l}7860,6150,3050,1640,1610,1150,1100,1080, \\
650,480,440,380,370\end{array}$ & 25960 \\
\hline Pvul I-Smal & $\begin{array}{l}7860,3460,3380,2660,1820,1760,1170,1150, \\
650,480,380,370\end{array}$ & 25140 \\
\hline PVul I-BamHI & $\begin{array}{l}6250,4650,3600,3460,3050,1170,1150,650,480, \\
380,370\end{array}$ & 25210 \\
\hline Clal-Hindlll & $9870,7080,5040,3130,400$ & 25520 \\
\hline
\end{tabular}




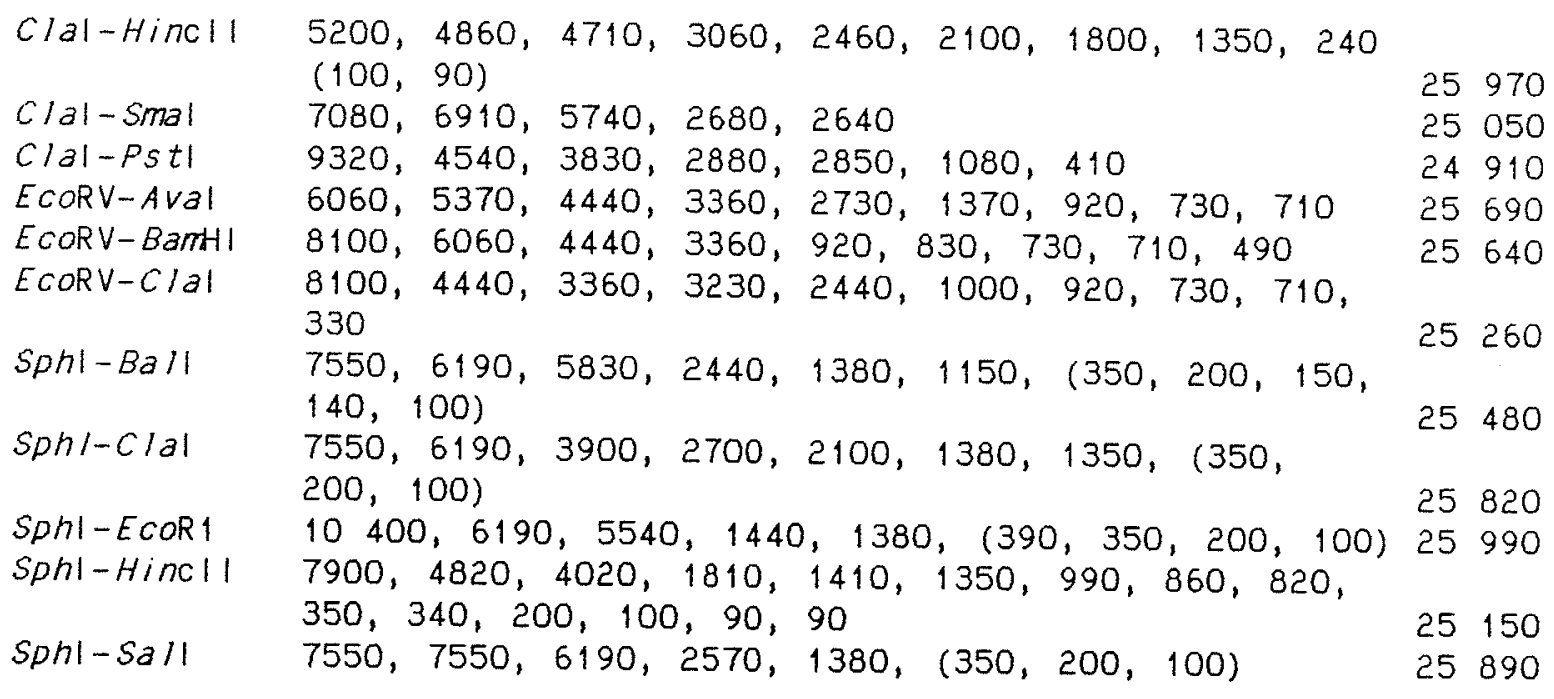
a brackets surround fragments too small to see on an agarose gel, but
presumed to be present 
Table 10. Restriction enzyme fragments obtained by digestion of ColE1 DNA

\begin{tabular}{|c|c|c|}
\hline $\begin{array}{l}\text { Restriction } \\
\text { Enzyme }\end{array}$ & Fragment Sizes (bp) & Sum(bp) \\
\hline ECORV & 5650,920 & 6570 \\
\hline Pstl & $5010,1080,410$ & 6500 \\
\hline Pvull & $4570,1160,380,370$ & 6480 \\
\hline ECORV-Clal & $3230,2440,920$ & 6590 \\
\hline ECoRV-Aval & 5650,920 & 6570 \\
\hline ECORV-Pstl & $5220,920,(410)^{a}$ & 6550 \\
\hline Pvull-Ball & $4570,1140,380,370$ & 6460 \\
\hline Pvul|-C|a| & $4570,870,380,370,260$ & 6450 \\
\hline Pvul I-Aval & $2670,1720,1160,380,370$ & 6320 \\
\hline$A v a l-B a l l$ & 3260,3070 & 6330 \\
\hline$A v a l-C|a|$ & 3390,2880 & 6270 \\
\hline Pstl-C|al & $2830,2230,1080,410$ & 6550 \\
\hline
\end{tabular}


Figure 5. Restriction map of pLC36-19. The thick black line represents the ColEl vector and the thin black line represents the $E$. coli genomic insert DNA. The map was generated using the restriction enzyme fragments given in Tables 9 and 10. Three small sphl fragments ( $350 \mathrm{bp}, 200 \mathrm{bp}$, and $400 \mathrm{bp}$ in size) have not been placed on the map because their positioning was questionable. The arrows on the inside of the circle point to the positions of the Tn5 insertions in pLC36-19 generating the plasmids PA30, PC1, pE6, and PD31. The positions of the Tn5 insertions were mapped using the restriction enzyme fragments given in Table 11 (Loewen et al., 1983; Triggs-Raine and Loewen, 1987). 


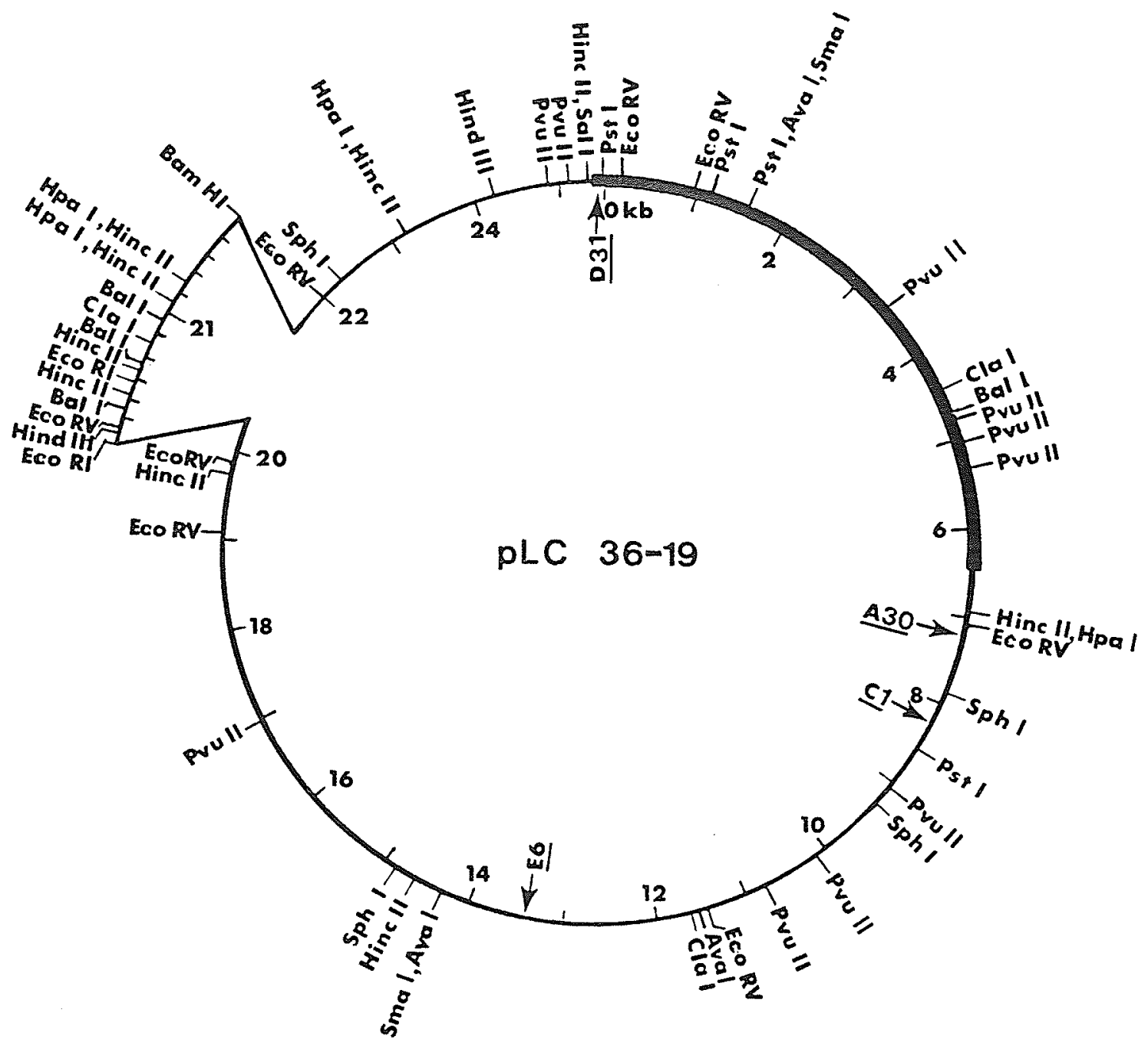


isolated from an agarose gel. Of the nucleases studied, BamHl, Sall, Pstl, and Smal cut only once, and $B g l l, X b a l, K p n l$, and $B C l l$ did not cut at all. Three small sphl restriction fragments could not be unequivocally placed because no restriction sites were found within them. These fragments have not been included in the pLC36-19 map, al though the best fit of the $s p h l$ fragments with the other restriction sites placed them in the 9 to $10 \mathrm{~kb}$ region of pLC36-19.

\subsection{Isolation and Mapping of Transposon Tn5 Insertions in pLC36-19}

The E.coli genomic DNA insert in pLC36-19 was $19.2 \mathrm{~kb}$ in size but only $2.5 \mathrm{~kb}$ was required to code for an $84 \mathrm{kd}$ protein, the size of the HPI subunit. To try to localize the gene encoding HPI on pLC36-19, transposon Tn5 insertions were made in the plasmid.

Small scale alkaline-SDS plasmid preparations for restriction enzyme digestion were done on approximately 220 potential pLC36-19::Tn5 containing colonies. The quality of the DNA from rapid plasmid preparations on these large plasmids was poor and it could only be used for comparing the size of the plasmids. Large scale plasmid preparations were done on plasmids which appeared larger than pLC36-19 so that they could be restricted to look for the presence of new bands indicative of the presence of Tn5. Seventeen pLC36-19 plasmids containing Tn5 insertions were identified, but of these, 14 were insertions in almost the same position. The Tn5 insertions in four different insertion plasmids, pA30, $p E 6, p C 1$, and $\mathrm{DD} 31$ were mapped by restriction enzyme digestion with Hindlll, Aval, and Pstl. Pstl digestions of all the other insertion plasmids were almost identical to PA30 suggesting that this area was a "hotspot" for Tn5 insertion. This was unexpected as Tn5 has been shown 
at the phenotypic level to have low insertional specificity. However, Tn5 has been shown to insert with higher frequencies into DNA sequences which have some homology to the Tn5 inverted repeat (De Bruijn and Lupski, 1984). No Tn5 insertions were found within the katG gene itself which has since been shown to have no obvious homologies with Tn5. The restriction fragment sizes for the 4 pLC36-19::Tn5 plasmids are in Table 11. None of the Tn5 insertions in pLC36-19 inactivated the catalase gene as is evident from the oxygraph values in Table 16 of the UM53 plasmid transformants. All of the plasmids complemented the catalase deficiency of UM53. The approximate locations of the mapped insertions are shown in Figure 5. A more detailed map of the plasmid PC4 is shown in Figure 6 .

\subsection{Localization of the HPI Coding Region by Deletion of pC1}

Although the transposon Tn5 insertions in pLC36-19 did not inactivate the catalase gene, the new sites provided by the transposon were exploited for deletion mutagenesis to localize the catalase gene. One of the Tn5 containing plasmids, $\mathrm{pC1}$, was restricted with Hindlll, religated, transformed into UM123, and selected on LBK plates. Because they had been selected on kanamycin, all of the resulting plasmids had to carry at least the Hindlll fragment from the transposon which contained the kanamycin resistance gene. All of the colonies appeared to have the same catalase levels on the agar plate.

Eighteen colonies were grown up and plasmids were prepared by the alkaline-SDS small scale procedure. Fifteen of the eighteen clones were smaller than pLC36-19, and two of these (labelled pBT1 and pBT2) were chosen for further characterization. Aliquots of large scale plasmid preparations of $\mathrm{PBT} 1$ and $\mathrm{PBT} 2$ were restricted by Hindl1 and the 
Table 11. Restriction enzyme fragments used to map Tn5 insertions in pLC36-19

\begin{tabular}{|c|c|c|c|c|}
\hline Plasmid & $\begin{array}{l}\text { Restriction } \\
\text { Enzyme }\end{array}$ & Fragment sizes (bp) & Sum & $(b p)$ \\
\hline PLC36-19 & Aval & $12600,10040,2730$ & 25 & 370 \\
\hline PLC36-19 & Hind $\mid 1$ & 21920,3800 & 25 & 720 \\
\hline$p L C 36-19$ & $P_{5} t 1$ & $17260,7010,1080,410$ & 25 & 760 \\
\hline pLC36-19 & $E \operatorname{CORV}$ & $\begin{array}{l}8100,6060,4440,3960,1370,920,730, \\
710 \\
12600,6470,4230,2730\end{array}$ & 25 & 690 \\
\hline$p C 1$ & Aval & $\begin{array}{l}12600,6470,4230,2730,1900,1180 \\
980,250,(250)^{a}\end{array}$ & 30 & 340 \\
\hline $\mathrm{pCl}$ & Hind III & $14050,9900,3830,3300$ & 31 & 080 \\
\hline $\mathrm{pCl}$ & Pstl & $\begin{array}{l}17260,7010,2480,1140,1080,920, \\
790,410\end{array}$ & 31 & 090 \\
\hline pA30 & Aval & $\begin{array}{l}12600,5880,5320,2730,2000,1180 \\
670,370\end{array}$ & 30 & 750 \\
\hline $\begin{array}{l}\text { PA30 } \\
\text { PA30 }\end{array}$ & $\begin{array}{l}\text { Hindlll } \\
\text { Pstl }\end{array}$ & $\begin{array}{lllll}14 & 000,10000,3830,3300 \\
17 & 260,5900,2230,1900,1080,900\end{array}$ & 31 & 130 \\
\hline pA30 & ECORV & $\begin{array}{l}17260,5900,2230,1900,1080,900 \\
800,410 \\
10740,8100,4440,3360,1370,920\end{array}$ & 30 & 480 \\
\hline pE6 & Aval & $\begin{array}{l}730,710 \\
12600,10040,2170,2000,1700,1180 \\
670,370\end{array}$ & 30 & 370 \\
\hline $\begin{array}{l}\mathrm{DE} 6 \\
\mathrm{DE} 6\end{array}$ & Hind III & $16000,8200,3830,3300$ & 31 & 330 \\
\hline $\mathrm{pE} 6$ & Pstl & $\begin{array}{l}13500,7010,4920,2470,1080,900, \\
850,410\end{array}$ & 31 & 140 \\
\hline pD31 & Aval & $\begin{array}{l}12000,10040,2770,2000,1270,1150, \\
750,400\end{array}$ & 30 & 380 \\
\hline $\begin{array}{l}\text { pD31 } \\
\text { pD31 }\end{array}$ & $\begin{array}{l}\text { Hindlll } \\
\text { Pstl }\end{array}$ & $\begin{array}{l}(20700), 3830,3300,2770 \\
17260,7010,2470,1200,1080,900 \\
850,(410)\end{array}$ & 30 & 600 \\
\hline
\end{tabular}

a the brackets indicate bands which either could not be seen on the gel but were known to be present or bands which could not be sized accurately on the gel 
Figure 6. Restriction maps of $\mathrm{pCl}$ and the Hindlll deletion der ivatives PBT1 and PBT2. The thick black lines represent the ColEl vector, the thin black lines represent the insert DNA, and the open box represents the transposon Tn5. The Aval and Clal sites of $\mathrm{DCl}$ were not included in the DBTI or PBT2 maps although they are still presumed to be present. The $4 \mathrm{Hincll}$ sites between 26 and $27 \mathrm{~Kb}$ on the $\mathrm{DCl}$ map are represented by a single Hincll site at $12.8 \mathrm{~kb}$ on the PBT2 map. 


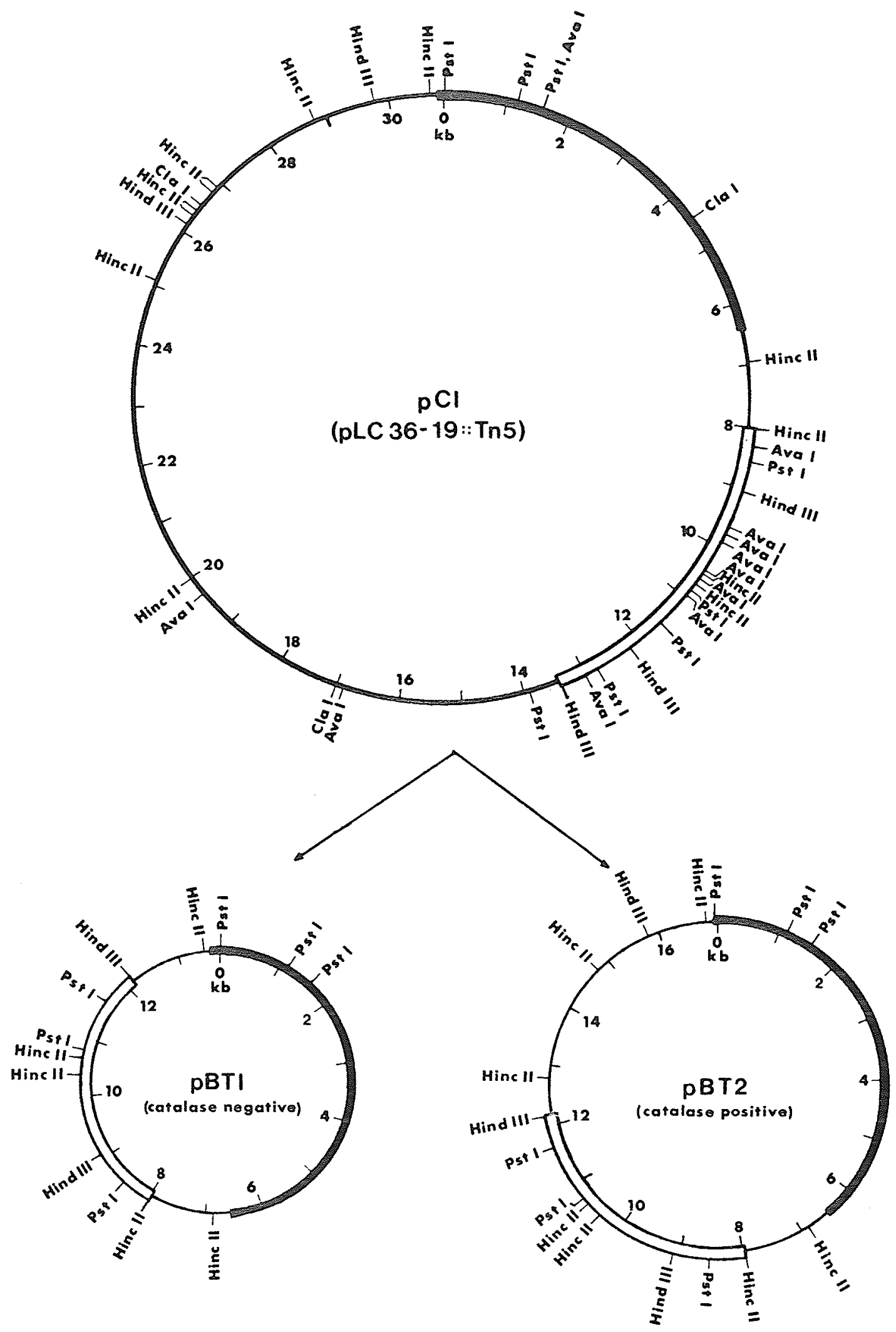


restriction patterns differed in only one fragment: PBT2 contained a 3.8 kb Hindlll fragment not present in PBT4 (see Figure 7). When these same plasmids were transformed into a completely catalase deficient mutant, UM53, their catalase levels also differed. PBT2 which contained the extra $3.8 \mathrm{~kb}$ Hindll fragment complemented the catalase deficiency of UM53, giving it catalase levels in the oxygraph of 3.7 u per mg dry cell wt with $1.5 \mathrm{mM} \mathrm{H} \mathrm{H}_{2} \mathrm{O}_{2}$ and $29.8 \mathrm{u}$ per $\mathrm{mg}$ dry cell wt with $60 \mathrm{mM} \mathrm{H}_{2} \mathrm{O}_{2}$, while PBT1 had no detectable catalase in the oxygraph. The oxygraph values for these strains are given in Table 16, and the construction of these deletion plasmids is shown in Figure 6 . These results suggested that all or part of the HPI gene was encoded in this $3.8 \mathrm{~kb}$ fragment.

The orientation of the $3.8 \mathrm{~kb}$ Hindlll fragment with respect to the vector was shown to be the same as in DCL36-19. Both DBT2 and DC1 were restricted with Hincll and the 1800 bp and 2100 bp fragments which cover the region between the beginning of the $3.8 \mathrm{~kb}$ fragment and the ColEl vector were identified in both plasmids, confirming the orientation to be the same. If the fragment had been reversed in or ientation, different restriction fragments would have resulted. The fragment sizes from the digests are given in Table 12 .

\subsection{Cloning and Restriction Mapping of the Catalase Gene}

The $3.8 \mathrm{~kb}$ Hindll fragment identified by deletion analys is to carry all or part of the catalase gene was cloned into the Hindll site of the small (3570 bp) high copy number vector, PAT153. The catalase activities of the clones were screened in the catalase deficient NG mutant, UM228 and plasmid DNA was prepared from 4 catalase positive colonies. All of the catalase positive clones contained the $3.8 \mathrm{~kb}$ 
Figure 7. Hindlll restriction endonuclease digestion showing the presence of a $3.8 \mathrm{~kb}$ fragment in PBT2 not found in PBT4. DNA samples were digested with Hindlll, electrophoretically separated on agarose gels, stained, and photographed. Lanes: $a, \lambda$ DNA; $b$, pBTI; $c$, pLC36-19; $d$ and $e, D C l ;$ and $f$, pBT2. Samples in lanes $a$, $b, c$, and $d$ were run on a separate gel from the samples in lanes $e$ and $f$ and consequently, the $\lambda$ - Hindlll standard in lane $a$ (fragment sizes shown in photograph) cannot be used to size the bands in lanes e and $f$. The $\mathrm{pCl}$-Hindlll digest in lane d however has also been included in lane e of the second gel as a size reference. 

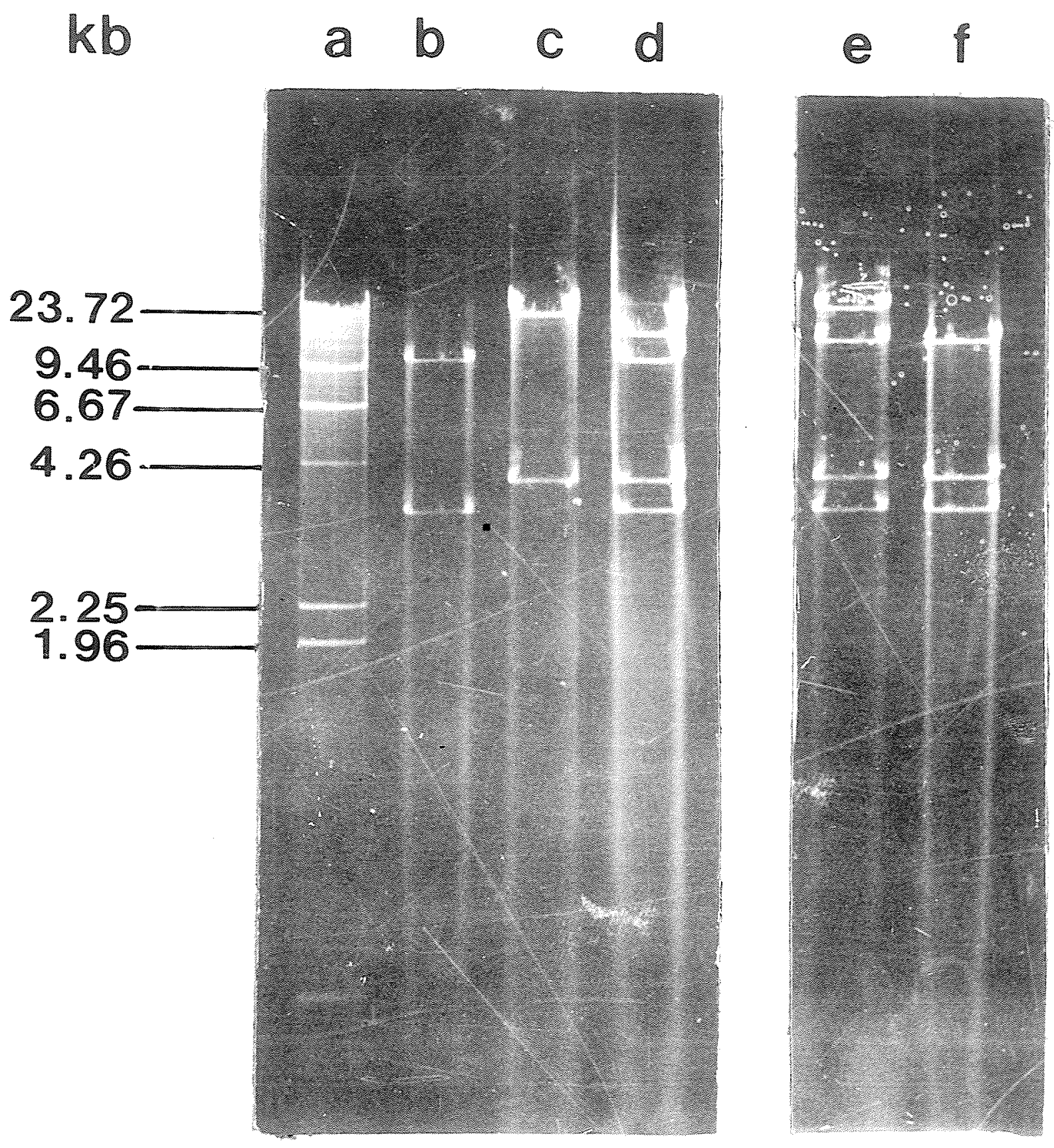
Table 12. Restriction fragments generated from $\mathrm{PBT} 2, \mathrm{pLC} 36-19$, and $\mathrm{pC} 1$ by Hincll

\begin{tabular}{llll}
\hline Plasmid & Restriction fragment sizes (bP) & Sum (bp) \\
\hline PLC36-19 & $7900,7050,5200,2100,1800,1350,340$ & 25740 \\
DC1 & $7050,7050,5200,2690,2430,2100,1800,1350$ & 29260 \\
PBT2 & 1100,340 & & 16820 \\
\hline
\end{tabular}


Hindlll fragment, but two types of restriction patterns were found when they were digested with ECoRV. One clone of each type of plasmid was prepared in large scale and these were labelled as PBT22 and DBT54 (sizes of the ECORV restriction fragments generated from these two plasmids are given in Tables 13 and 15). These two plasmids contained the same Hindlll insert, but in opposite orientations. The fact that the catalase gene was active in both orientations confirmed that the entire gene was present in this fragment, including the promoter, and that expression of the catalase gene was not affected by the close proximity of the insert to the tetracycline promoter in PBT22.

Crude extracts from the cells were electrophoresed on polyacrylamide gels and stained for catalase and peroxidase (see Figure 8). Although UM228 did produce residual HPI it was obvious that the plasmid containing strains were producing much larger quantities of the HPI A and B doublet.

The plasmids were transformed into UM53 and extracts of the plasmid harbouring bacteria were assayed for catalase using the oxygraph. The plasmids conferred very high levels of catalase activity to UM53 both on the agar plate and in the oxygraph. The levels were much higher than when the same fragment was cloned in the lower copy number vector ColE1 (pBT2). The oxygraph values are given in Table 16.

PBT22 was restriction mapped in detail. The restriction sites were first placed using the restriction digests given in Table 13 , and then ordered in detail with the help of restriction fragments electrophoresed and sized on acrylamide gels (see Table 14). In total, sites for 14 restriction enzymes were mapped in the plasmid for a total of 37 restriction sites, the majority of which were clustered at the $0 \mathrm{~kb}$ end 
Figure 8. Visualization of catalase and peroxidase activities in UM228 and the plasmid containing derivatives UM228/DBT22 and UM228/pBT54. Lanes $b, d$, and $f$ were stained for catalase activity and lanes $a, c$, and e were stained for peroxidase activity. The following samples were run: lanes $a$ and $b$ from UM228/DBT54, $676 \mu \mathrm{g}$ protein; lanes $\mathrm{c}$ and d from UM228/pBT22, $490 \mu \mathrm{g}$ protein, and lanes $e$ and $f$ from UM228, $654 \mu g$ protein. 


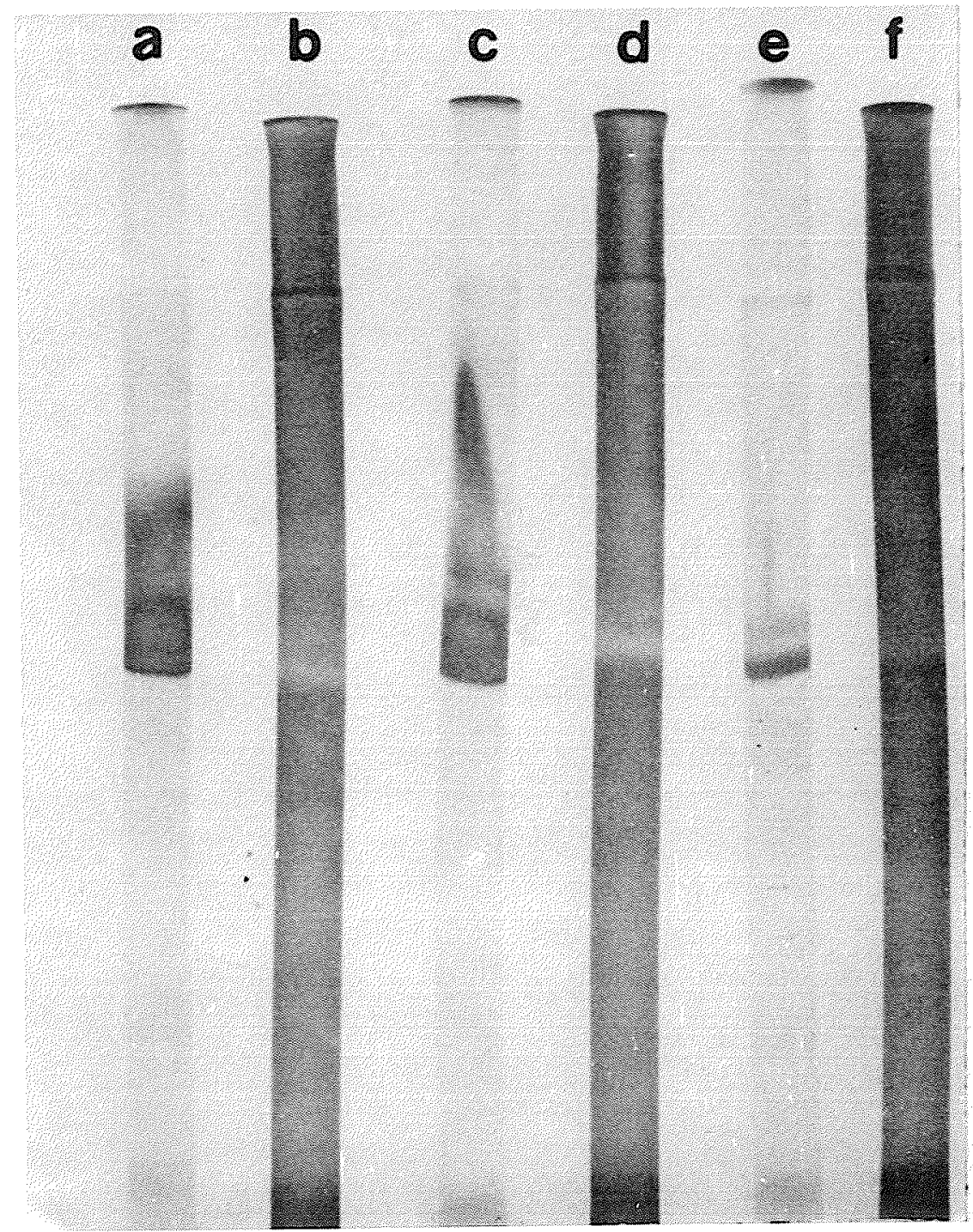


Table 13. Restriction enzyme fragments generated from pBT22

\begin{tabular}{|c|c|c|}
\hline Enzyme & Fragment sizes (DP) & Sum (bp) \\
\hline$A C C l$ & $3940, \quad 3230$ & 7170 \\
\hline$B g \| 1$ & $6370,810,320,140$ & 7640 \\
\hline Clal & 6900,480 & 7380 \\
\hline ECORV & $3460,2280,1380$ & 7120 \\
\hline Hindll & $2520,2120,1620,735,340,110,90$ & 7535 \\
\hline Hindl\| & 3830,3570 & 7400 \\
\hline Nrul & $2770,1900,1250,1250$ & 7170 \\
\hline$A C C l-C l a l$ & $3230,2860,650,(480)^{a}$ & 7220 \\
\hline$A C C l-E C O R V$ & $3040,2280,1040,500,450$ & 7340 \\
\hline$A C C l-H i n d \mid I$ & $2440,1700,1530,735,360,340,110,90$ & 7305 \\
\hline ECoRV-Clal & $3500,2300,1400,(480)$ & 7680 \\
\hline Hindll-ECORV & $\begin{array}{l}2520,1250,1150,950,680,440,340,110 \\
100,90\end{array}$ & 7600 \\
\hline Hind ||$-S p h \mid$ & $2520,1620,1150,1000,735,340,(100,90)$ & 7555 \\
\hline Hind ||-BamH| & $2520,1720,1330,735,370,340,310,110,90$ & 7525 \\
\hline Hindl|l-Hind।I & $2520,2120,850,620,545,340,270,110,90$ & 7465 \\
\hline Hind ||$|-S p h|$ & $3030,1980,1980,530$ & 7520 \\
\hline Hind || |-BamH| & $3230,2640,1220,350$ & 7440 \\
\hline Hindl II-Clal & $3570,3360,480$ & 7410 \\
\hline Nrul-Hindll & $\begin{array}{l}2080,1610,1250,700,640,340,280,170 \\
110,90\end{array}$ & 7270 \\
\hline Nrul-Clal & $2540,1900,1250,1040,240,240$ & 7210 \\
\hline Nrul-ECORV & $2770,1250,1200,1100,700,260,100$ & 7380 \\
\hline
\end{tabular}


Table 14. Restriction fragments of $\mathrm{pBT} 22$ sized on acrylamide gels and used to order restriction enzyme sites

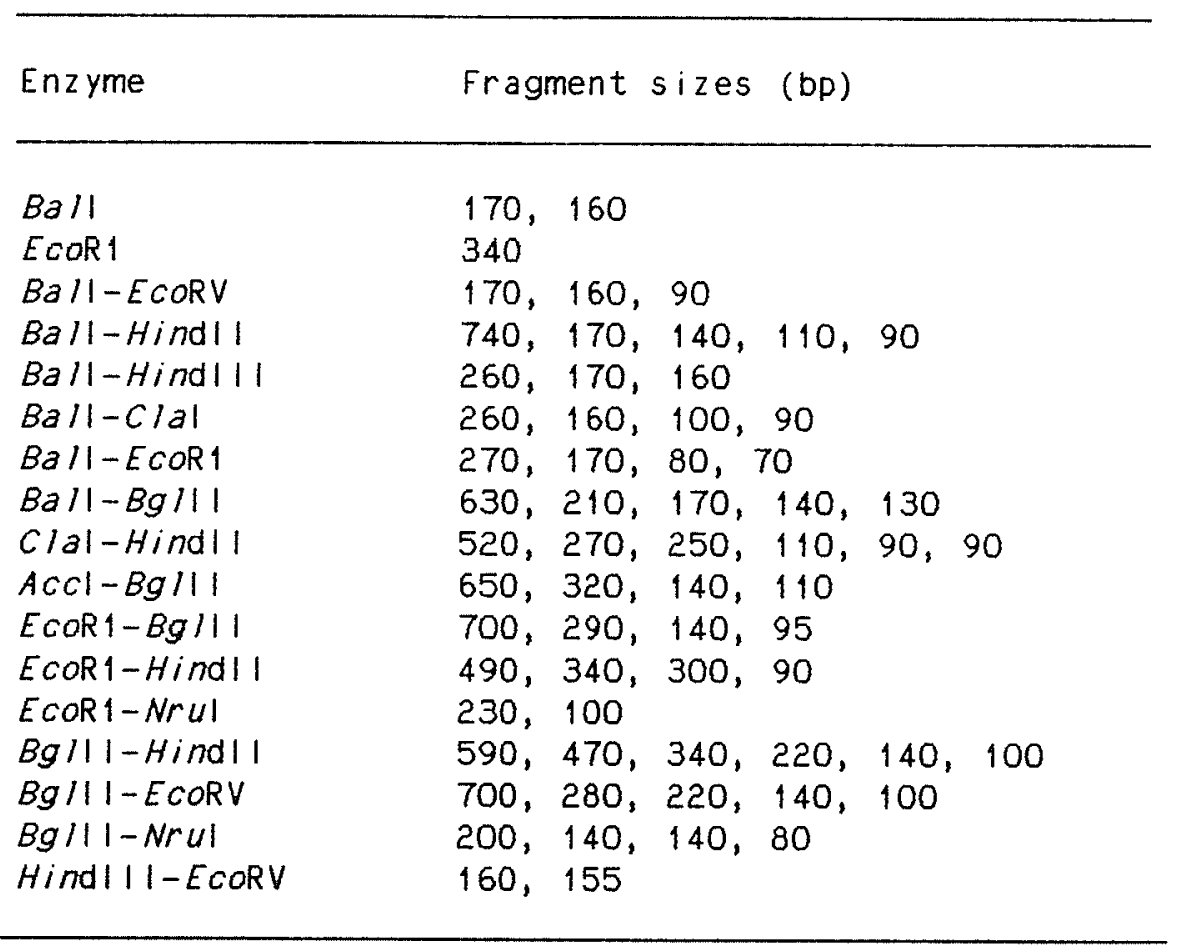


of the DBT22 insert. The restriction map of the plasmid is shown in Figure 9.

PBT54, which contained the same insert but in the opposite orientation was restricted with Hincll to confirm the opposite orientation of the insert. A map containing the restriction fragments from Table 15 is shown in Figure 10.

\subsection{Definition of the Boundaries of the HPI Gene}

\subsubsection{Definition of the $0 \mathrm{~kb}$ End by a Specific EcoRl Deletion}

The plasmid DBT22 was restricted with ECORI, religated, and transformed into UM228. Colonies selected on LBA plates were screened for catalase activity by the $\mathrm{H}_{2} \mathrm{O}_{2}$ drop test and a large scale plasmid preparation was done on one catalase negative colony. The plasmid was called PBT24. An ECORI digest of PBT24 produced one band on an agarose gel and no small bands on an acrylamide gel, confirming that the $340 \mathrm{bp}$ ECoR1 fragment had been deleted. When PBT24 was transformed into UM53, no catalase activity was produced as shown by the oxygraph values in Table 16. The placement of this deletion with reference to the $0 \mathrm{~kb}$ end of the plasmid is shown in Figure 12. These results showed that part of the catalase coding region or controlling region must start before the EcoRl site, placing it within 300 bp of the $0 \mathrm{~kb}$ end.

\subsubsection{Cloning of a 7550 bp Sphl fragment from plC36-19}

A Sphl restriction digest of the Tn5 containing derivative of pLC36-19, pA30, was ligated with Sphl restricted PAT153 and then transformed into UM123. The plasmid containing cells were selected on LBA plates and screened for recombinant plasmids $\left(T C^{S}\right)$ on LBT plates. Plasmid screening preparations were done on twelve $T c^{S}$ clones, and DNA 
Figure 9. Restriction map of pBT22. The thick line represents the vector DAT153, and the thin line represents the insert DNA. The $0 \mathrm{~kb}$ end marks the start of the $3.8 \mathrm{~kb}$ Hindlll insert. The map was made using the restriction fragments in Tables 13 and 14 (TriggsRaine and Loewen, 1987). 


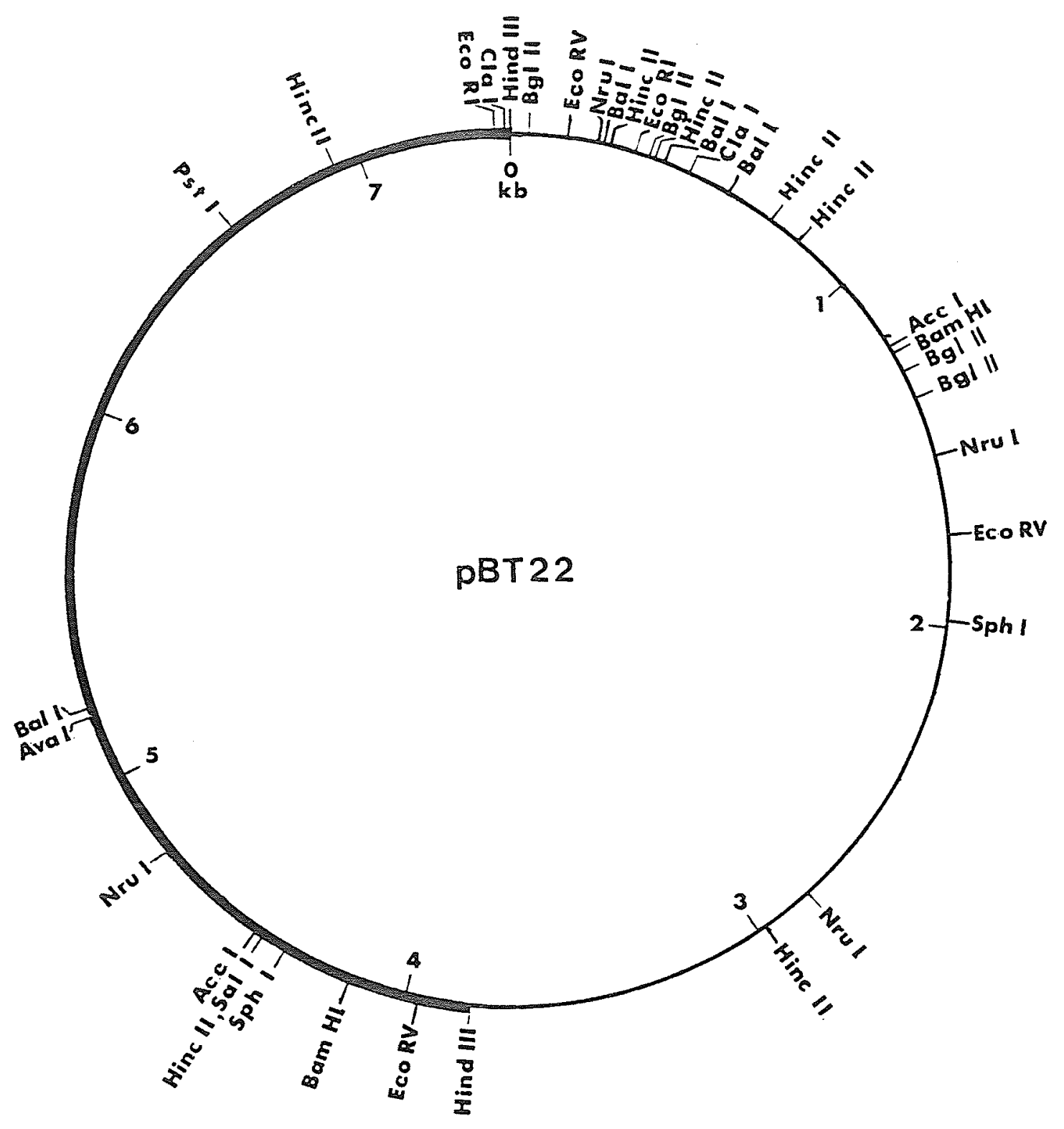


Table 15. Restriction enzyme fragments generated from PBT54

\begin{tabular}{lll}
\hline Enzyme & Fragment sizes (bp) & Sum (bp) \\
\hline Hindlll & 3830,3570 & 7400 \\
Hincll & $2520,2100,1450,930,340,(100,90)$ a & 7530 \\
ECoRV & $5500,1380,400$ & 7280 \\
\hline
\end{tabular}

a Brackets surround bands not visible on an agarose gel 
Figure 10. Restriction map of PBT54. The thick line represents the vector, PAT153, and the thin black line represents the insert DNA. Although not substantiated by restriction enzyme digests, the same restriction enzyme sites present in the DBT22 insert should be present in this insert since it is simply reversed in orientation. 


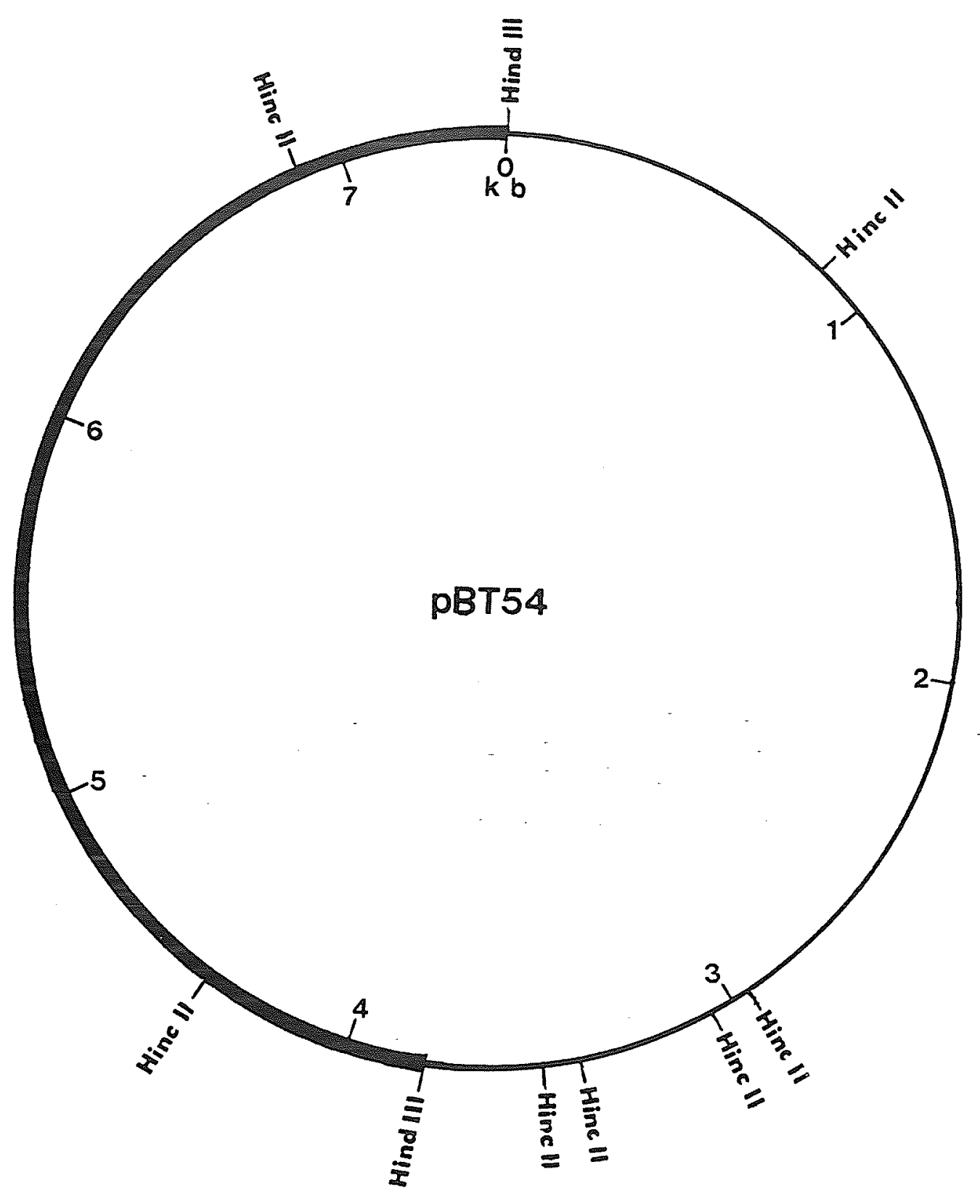


Table 16. Catalase activity in log phase UM53 containing various plasmids

\begin{tabular}{|c|c|c|}
\hline Strain & $\begin{array}{l}\text { Catalase Activity (u/mg } \\
1.5 \mathrm{mM} \mathrm{H} \mathrm{H}_{2}\end{array}$ & $\begin{array}{l}\text { dry cell wt) } \\
60 \mathrm{mM} \mathrm{H} \mathrm{H}_{2} \mathrm{O}_{2}\end{array}$ \\
\hline UM53 & $N^{a}$ & 0.2 \\
\hline UM53/PLC36-19 & 4.9 & 31.9 \\
\hline UM53/DC1 & 3.5 & 21.0 \\
\hline UM53/DE6 & 4.0 & 26.4 \\
\hline UM53/DA30 & 3.6 & 20.6 \\
\hline UM53/DD31 & 0.3 & 3.3 \\
\hline UM53/pBT5 & ND & ND \\
\hline UM53/pBT22 & 7.1 & 91.6 \\
\hline UM53/pBT54 & 6.2 & 80.0 \\
\hline UM53/pBT30 & ND & $1.5^{b}$ \\
\hline UM53/pBT29 & ND & ND \\
\hline UM53/pBT28 & 8.4 & 109.3 \\
\hline UM53/pBT24 & ND & ND \\
\hline UM53/pBT2 & 3.7 & 29.8 \\
\hline UM53/pBT1 & ND & ND \\
\hline
\end{tabular}


from the largest plasmid, PBT5, was prepared for restriction enzyme digestion. DBT5 was found to contain the 7550 bp sphl fragment from pLC36-19 that included a large portion of the $3.8 \mathrm{~kb}$ Hindll fragment cloned into PBT22 and extended through the $0 \mathrm{~kb}$ end of the Hindlll fragment into pLC36-19. The orientation of the Sphl fragment in DAT153 was determined from the restriction enzyme digests given in Table 17 and the restriction map is shown in Figure 11.

DBT5 was transformed into the catalase deficient mutant UM53, but it was unable to complement the catalase mutation (see Table 16 for the oxygraph assay values). This showed that the entire HPI gene was not contained in DBT5 and that the HPI gene must extend from within 300 bP of the $0 \mathrm{~kb}$ end to beyond the sphl site at approximately $2 \mathrm{~kb}$ on the pBT22 map (See Figure 12).

\subsubsection{Definition of the 3.8 kb End of the Gene by BAL31 Deletions}

BAL31 deletion plasmids were constructed as described in section

3.12.2. Several plates of $A P^{R}$ colonies were picked onto another $L B$ plate and scored for catalase by the $\mathrm{H}_{2} \mathrm{O}_{2}$ drop test. Rapid plasmid preparations from five catalase negative and two catalase positive colonies were run on an agarose gel. The largest of the catalase negative plasmids was named PBT25. Plasmid DNA from a large scale preparation of PBT25 was restricted by Hindlll, Hincll, and Nrul (data not shown). The deletion of DBT25 was found to extend from between the Nrul site and the Sall site of PAT153 to between the Hincll site closest to the $3.8 \mathrm{~kb}$ end of the insert and the EcoRV site at $1.75 \mathrm{~kb}$ (refer to the DBT22 map in Figure 9). All Sphl sites were absent. PBT25 was then used as a size control to look for larger catalase negative plasmids. 
Table 17. Restriction enzyme fragments generated from pBT5

\begin{tabular}{lll}
\hline Enzyme & Fragment size (bp) & Sum (bp) \\
\hline Sphl & 7550,3570 & 11120 \\
BamHI & 9410,860 & 10270 \\
EcoRl & $8430,2000,400$ & 10830 \\
Hindl1 & 8630,2350 & 10980 \\
Clal & 9000,1830 & 10830 \\
\hline
\end{tabular}


Figure 11. Restriction map of DBT5. The thick line represents the vector, PAT153 and the thin line represents the insert DNA. 


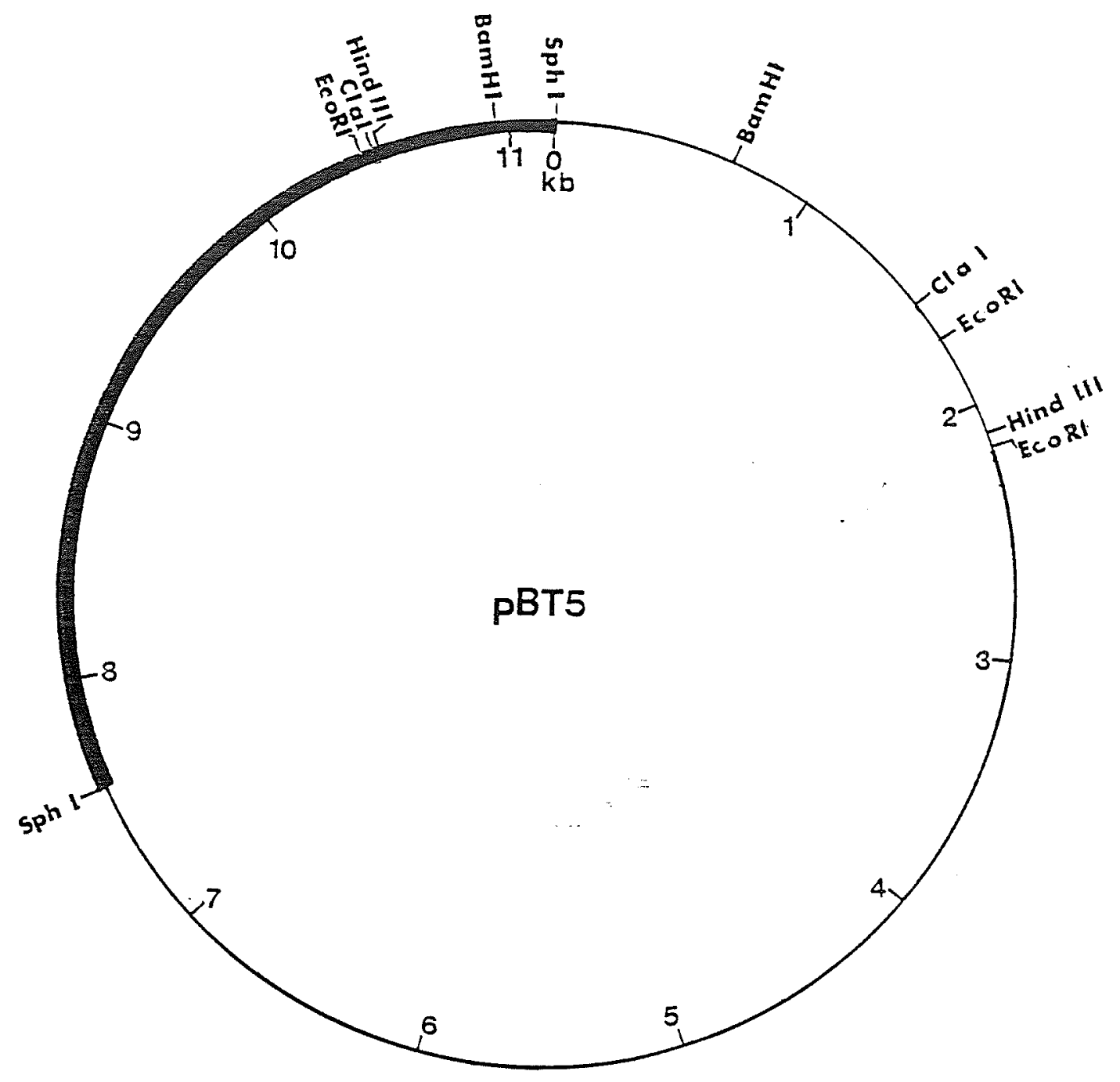


Figure 12. Localization of katG by deletion mapping of PBT5, DBT24, DBT28, DBT29, and PBT30. The thick line represents the vector DNA while the thin line represents the insert DNA. The asterisk indicates that PBT5 extends beyond the Hindlll site at the $0 \mathrm{~kb}$ end to the next Sphl in the E. Coli genomic DNA insert of pLC36-19. The arrow indicates the direction of transcription of the katG gene (Triggs-Raine and Loewen, 1987). 


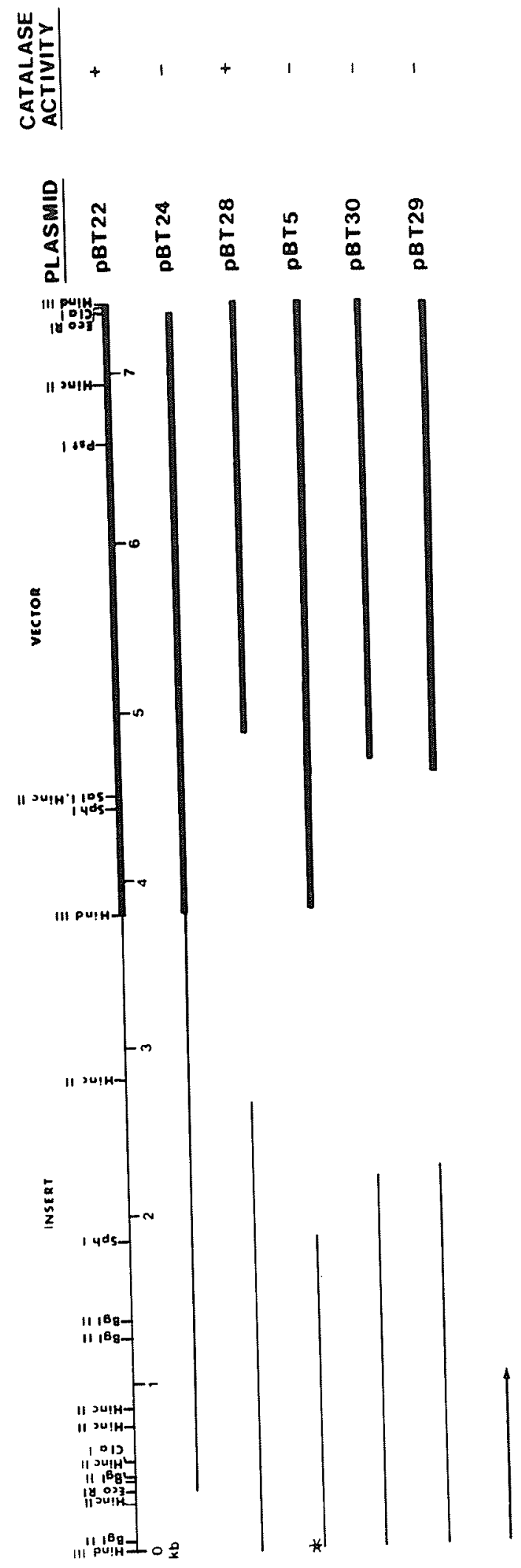


Plasmids from approximately 80 colonies were screened by electrophoresis on an agarose gel with DBT22 and DBT25 as upper and lower limit size controls. The catalase activity of these colonies on agar plates was also scored. From these 80 plasmids, one catalase positive plasmid, pBT28, and two catalase negative plasmids (pBT29 and PBT30), all larger than PBT25 were chosen for further characterization. The deletions in the plasmids were roughly mapped using the restriction enzyme digests given in Table 18. These restriction digests were also useful because they allowed Rsal sites to be mapped in pBT28 and this enzyme was later used to clone fragments for sequencing. Approximately 2100 bp had been deleted from pBT28 leaving a 5300 bp plasmid which complemented the catalase deficiency of UM53 (See table 16). The deletion in PBT28 was found to extend from the Ball site in the vector past the Hincll site at the $3.8 \mathrm{~kb}$ end of the insert but ending before the Nrul site following this. The extent of the deletion is illustrated in Figure 12. DBT29 and DBT30 had deletions extending from approximately the same place in the vector through the Hincll site at the $3.8 \mathrm{~kb}$ end of the insert and beyond the Nrul site, but ending before the sphl site (see Figure 12). The deletions of PBT29 and PBT30 were almost exactly the same, PBT30 having only a slightly larger deletion. The extra DNA which has been deleted could be from the vector or the insert since there were no restriction enzymes mapped in this area to allow more precise definition. In Figure 12, the extra deleted DNA in DBT30 has simply been divided between the vector and the insert, although the exact boundaries are unknown. The ECORV-Sphl digests of PBT29 and PBT30 shown in Table 18 confirmed that the sphl sites were still present in both instances, but the resulting small fragment could not be seen on the agarose gel making 
Table 18. Restriction enzyme fragments used to map pBT28, PBT29, and pBT30

\begin{tabular}{|c|c|c|c|}
\hline Plasmid & Enzyme (s) & Fragment size (bp) & sum $(b p)$ \\
\hline PBT28 & $B g \| 1$ & $3980,810,330,140$ & 5260 \\
\hline PBT28 & ECORV & $3830, \quad 1380$ & 5210 \\
\hline pBT28 & Hincl| & $4030,735,340,140,90$ & 5305 \\
\hline PBT28 & Nrul & 3910,1250 & 5160 \\
\hline pBT28 & Rsal & $2840,1200,640,480,200$ & 5360 \\
\hline pBT28 & $B g \||-R s a|$ & $2780,640,480,360,330,300,200,150$ & $140 \quad 5380$ \\
\hline PBT28 & ECORV-Rsal & $2840,700,520,500,480,(200)^{a}$ & $5040(5240)^{b}$ \\
\hline pBT28 & ECORV-AVal & $2320,1500,1380$ & 5200 \\
\hline pBT28 & $S p h l-A v a !$ & 4110,1110 & 5220 \\
\hline PBT28 & Rsal-BamHI & $2840,1200,530,480,(200)$ & $5050(5250)$ \\
\hline pBT28 & Rsal-Clal & $2840,640,520,480,480,(200),(200)$ & $4960(5360)$ \\
\hline pBT28 & Rsal-Sphl & $2840,1200,640,480$ & 5160 \\
\hline DBT29 & ECORV & 3530,1380 & 4910 \\
\hline PBT29 & Nrul & $2720,1250,810$ & 4780 \\
\hline PBT29 & Rsal & $2640,1200,640,460,200$ & 5140 \\
\hline DBT29 & $E C O R V-S p h I$ & 3290,1380 & 4670 \\
\hline pBT30 & ECORV & 3360,1380 & 4740 \\
\hline PBT30 & Nrul & $2750,1250,810$ & 4810 \\
\hline DBT30 & Rsal & $2570,1200,640,460,200$ & 5070 \\
\hline pBT30 & ECORV-Sphl & 3260,1380 & 4640 \\
\hline
\end{tabular}

a brackets surround fragments whose presence was inferred but no acrylamide gel was run to confirm this

$b$ brackets surround sums that include the values of the fragments inferred to be present 
the total size of the plasmids appear smaller for these digests.

\subsection{Identification of the Promoter}

\subsubsection{Immunodiffusion Analys is of Partially Purified HPI}

Crude catalase preparations were prepared from UM262, UM262/pBT22, UM262/pBT24, and UM262/PBT5 following the partial purification procedure for HPI catalase outlined in section 3.14.1. UM262 was chosen as the host strain for these preparations because it produced no HPI catalase and therefore should produce no anti-HPI precipitable protein. The UM262/pBT22 preparation provided a model for the other preparations because it was the only strain carrying a catalase positive plasmid and thus allowed catalase activity to be assayed throughout the preparation. As illustrated in Figure 13, when protein from UM262/DBT22 was run through a DEAE-Sephadex column, the fractions containing the large protein peak, tubes 14 to 34 , also contained the HPI catalase peak. It was hoped that by pooling the fractions covering the protein peak, during the subsequent preparation of UM262/DBT24 and UM262/DBT5, any inactive HPI protein with similar properties would be included. The inactive HPI protein would then be detected with anti-HPI.

The deletions in PBT5 and PBT24 were known to be at opposite ends of the $3.8 \mathrm{~kb}$ Hindlll fragment carrying the HPI gene, yet both plasmids were catalase negative. If a cross reacting protein from the partial HPI purification was detected with anti-HPI in one strain but not in the other, this might suggest at which end of the insert the promoter was situated. The presence of an immunoprecipitable protein without catalase activity would suggest that the deletion in the plasmid in this strain was in the end of the gene encoding the carboxyl terminus of the HPI protein. A deletion in the promoter end would likely produce no anti-HPI 
Figure 13. Determination of protein concentrations and catalase activity in fractions collected from a DEAE-Sephadex column. Approximately $500 \mathrm{mg}$ of crude protein from UM262/DBT22 was loaded on a DEAE-Sephadex column and after washing the column with phosphate buffer, $0.5 \mathrm{M} \mathrm{NaCl}$ was run through the column and 100-75 drop fractions were collected. The protein peak was followed by taking the $A_{280}$ of certain fractions ( $\square$ ), and the catalase peak was followed by assaying the fractions with $1.5 \mathrm{mM} \mathrm{H}_{2} \mathrm{O}_{2}$ in the oxygraph. (0) The arrows indicate the fractions which were pooled to provide a crude catalase preparation for immunodiffusion analysis. 


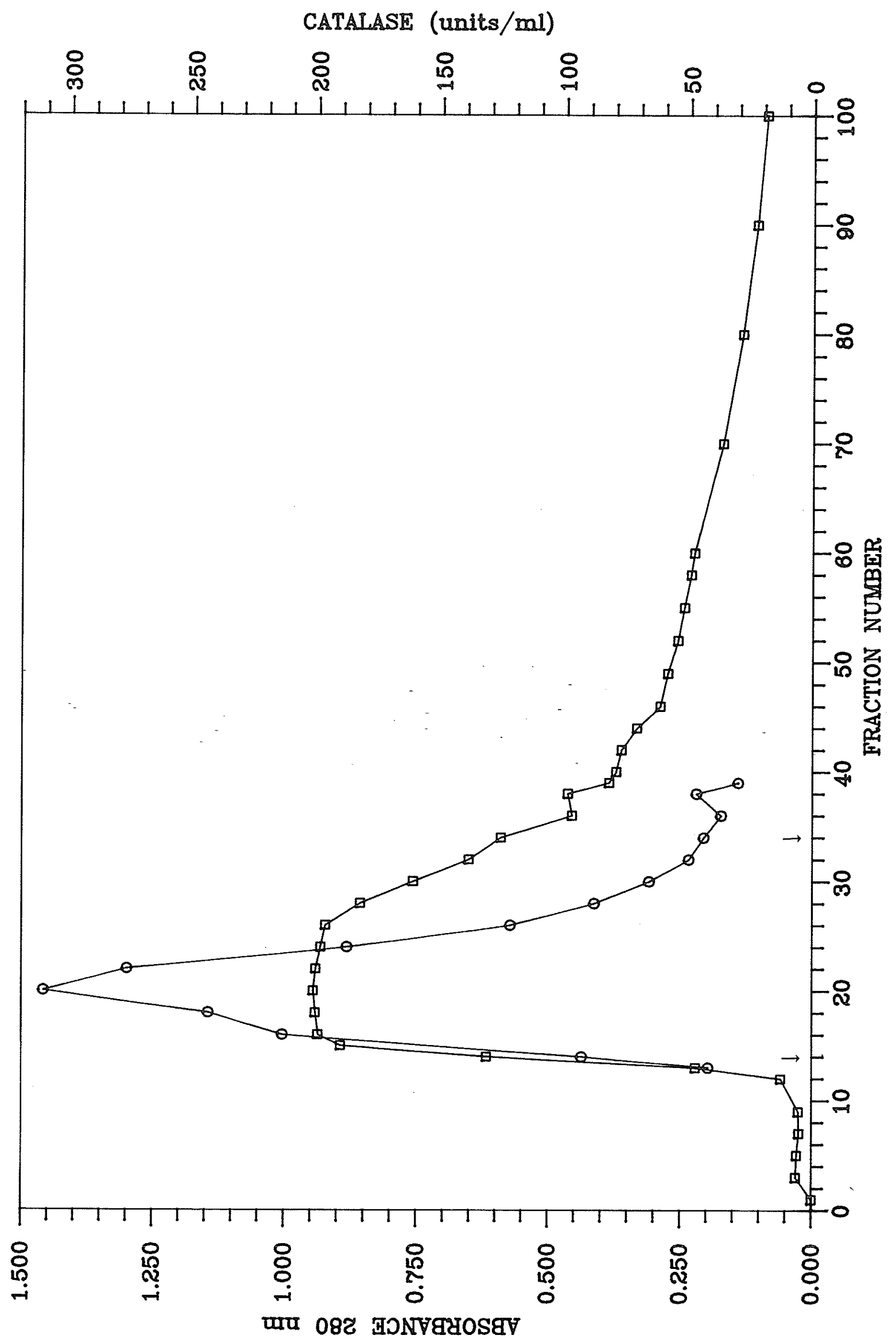


detectable protein.

The crude catalase preparations from the three plasmid bearing strains and UM262 itself were used for immunodiffusion analys is against anti-HPI. Fifty HL of each sample was placed in a well in an immunodiffusion plate surrounding a central well containing $50 \mu \mathrm{L}$ of anti-HPI. After allowing the samples to react, only the UM262/PBT22 preparation was found to contain immunoprecipitable protein (see figure 14). The absence of immunoprecipitable protein in the strains bearing the deletion plasmids prevented the identification of any one end as promoter containing. Since one deletion must be in the carboxyl terminus of the gene the absence of immunoprecipitable protein suggested that the loss of the carboxyl end of the protein may prevent the polypeptide from folding into a structure recognizable by any of the polyclonal population of antibodies present in the HPI antisera or that the protein was so unstable that it was quickly degraded, preventing it from being detected with the antisera. The absence of any cross reacting protein in the UM262/DBT5 deletion plasmid will be further alluded to in the next section.

\subsubsection{Maxicell Analys is of Plasmid Encoded Polypeptides}

The plasmid encoded polypeptides from pBT22, PBT54, PBT5, and the related deletion plasmids DBT28, DBT29, DBT30, and DBT24 were analyzed by maxicell expression. The autoradiogram of the plasmid encoded polypeptides is shown in Figure 15. Cells containing no plasmids produced no protein bands, only a fast running band of cell debris and associated label. A single protein band with a relative molecular weight $\left(M_{r}\right)$ of 32000 was produced by cells containing the plasmid vector PAT153. The $A p^{R}$ gene of $\mathrm{pAT153}$ codes for two proteins weighing 28000 daltons and 
Figure 14. Immunodiffusion analys is of crude catalase preparations against anti-HPI. Wells: a, UM262; b, UM262/DBT5; c, UM262/DBT22; d, UM262/DBT24; e, UM262/PBT22. 





Figure 15. Maxicell analys is of plasmid encoded polypeptides. $14 \mathrm{C}$-labelled polypeptides were analyzed by electrophores is on an 8.0\% SDS-Dolyacrylamide gel. Lanes: a, CSR603; b, CSR603/DAT453; c, CSR603/pBT22 (katG $) ; d$, CSR603/pBT54 (katG $\left.{ }^{+}\right) ;$e, CSR603/pBT28 $\left(k a t G^{+}\right) ; f$, CSR603/pBT29 (katG); g, CSR603/pBT30 (katG); $h$, CSR603/pBT24 (katG); i, UM262/pBT5 (katG) (Triggs-Raine and Loewen, 1987). 


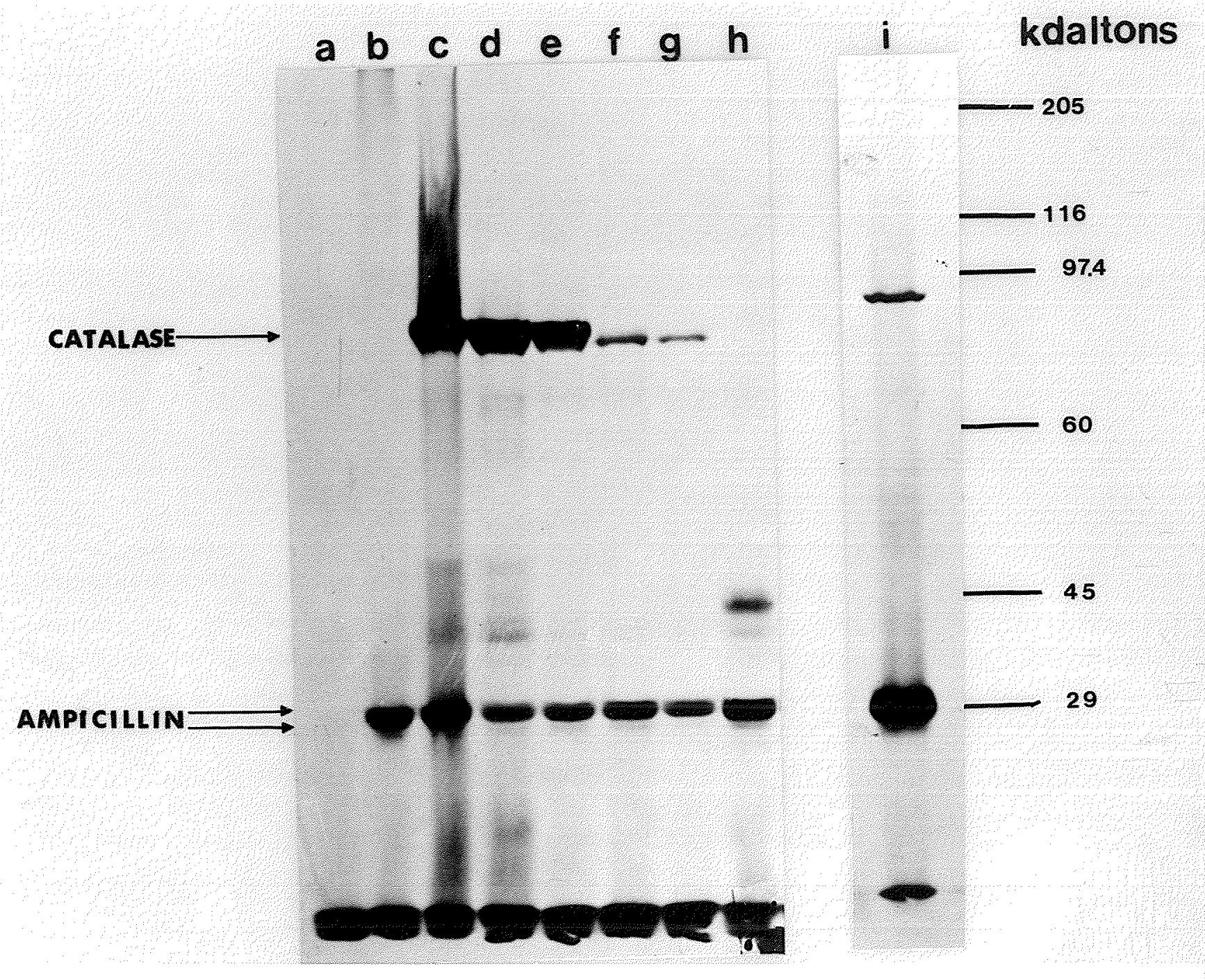


31000 daltons (Sancar et al., 1979) which appeared here as the strong 32000 dalton band under which a weaker band was sometimes visible. The $T_{C}{ }^{R}$ gene produces a weak band at 37000 daltons (Sancar et al., 1979) which could not be seen on this autoradiogram. The catalase positive plasmids, PBT22, PBT54, and PBT28 contained the $A P^{R}$ gene products but also a new protein band at 84000 daltons, the same size as the HPI subunit. The intensity of the HPI protein band relative to the ampicillin resistance protein indicated that all three plasmids produced a stable HPI protein at comparable efficiencies.

The deletion plasmids PBT29, PBT30, and PBT24 were useful in defining the location of the promoter. The two catalase negative BAL31 deletion plasmids, PBT29 and PBT30 produced a band of the same size or slightly smaller than the 84000 dalton band produced from the catalase positive plasmids, as well as the $A p^{R}$ gene products. The weak intensity of the 84000 dalton band in comparison to the $A p^{R}$ gene products suggested that the protein was unstable. The production of an unstable, but almost full size protein from these plasmids suggested the deletions at the $3.8 \mathrm{~kb}$ end of the insert were in the carboxyl terminal coding portion of the gene. If this were the promoter containing end of the gene the deletion would probably prevent the production of any HPI protein. PBT24, which had a deletion at the $0 \mathrm{~kb}$ end of the insert would then be expected to produce no protein if it were in the promoter region. However, besides the $A p^{R}$ proteins a second protein band appeared at 45000 daltons. Although the presence of this band was not understood it was known that if the carboxyl terminus were at the $0 \mathrm{~kb}$ end, such $a$ small. deletion would not result in a protein this small, so it still supported the hypothes is that the $\mathrm{O} \mathrm{kb}$ end contained the promoter. 
The sphl clone, PBT5, produced an unusual protein product as well. Because pBT5 contains an even larger deletion at the $3.8 \mathrm{~kb}$ end than either PBT29 or DBT30, it was expected to produce an even smaller HPI derivative. Instead it produced a protein band slightly larger than HPI, having a $M_{r}$ of 92000 . This polypeptide is unlikely to have resulted from the in-frame fusion of the existing portion of the HPI gene and the $\mathrm{Tc}^{R}$ gene because this fusion protein would be about 75 amino acids smaller than the HPI protein. The larger deletion in the HPI coding sequence of PBT5 may have made the protein so unstable that it was no longer present in large enough quantities to be visible in the autoradiogram. The new protein band at 92000 daltons could then be a polypeptide coded for by the large piece of DNA extending beyond the $0 \mathrm{~kb}$ end of the insert to the next Sphl site of DLC36-19. It was known from the immunodiffusion analysis in the previous section that the protein product of DBT5 was either lost during purification because of its altered properties or that it was not similar enough to cross-react with HPI antisera.

\subsubsection{Cloning of the Promoter}

As final confirmation that the HPI gene promoter was at the $0 \mathrm{~kb}$ end of the $3.8 \mathrm{~kb}$ Hindll fragment, a $320 \mathrm{bp}$ Bglll promoter containing fragment was selected in the promoter cloning vector pKK232-8 (Pharmacia).

The pBR322 derivative, pKK232-8 contains a promoter less chloramphenicol acetyltransferase (CAT) gene which can be activated by inserting a promoter in front of it. A multiple cloning site which precedes the gene makes the insertion of fragments very simple. Other features engineered into the plasmid include transcription terminators 
flanking the gene to prevent DBR322 promoters from interfering with CAT expression and translational stop signals in all three reading frames between the multiple cloning region and the CAT gene to prevent the production of fusion proteins. A Shine-Dalgarno sequence is appropriately placed in front of the promoterless CAT gene so that only the transcriptional promoter sequences are required to express the CAT gene. The plasmid also contains an $A D^{R}$ gene for the selection of the plasmid (Brosius, 1984).

pKK232-8 was restricted with BamHl which cuts in the multiple cloning region and $B g / l l$ fragments from DBT22 were ligated in. The ligation mixture was transformed into UM228 and plasmid containing colonies were selected on LBA plates. Approximately 240 colonies were picked onto LB plates containing $10 \mu \mathrm{g} / \mathrm{mL}$ and $20 \mu \mathrm{g} / \mathrm{mL}$ of chloramphenicol. Plasmids were isolated from two colonies which grew better than the others. On an agarose gel, both plasmids appeared the same size or slightly larger than pKK232-8. One of the plasmids was named pGprmi and prepared on a large scale.

The Bglll insert in pGprmi could no longer be cut out with the same enzyme because BanHI/BgllI hybrid sites are not recognized by either enzyme. The fragment was cut out by restriction with smal and Sall which cut on either side of the BamHl site in the multiple cloning region. As illustrated in Figure 16, the resulting fragment was 330 bp in size, almost exactly the same size as the 320 bp Bg/ll fragment produced from DBT22. The fragment was slightly larger because of the additional base pairs from the multiple cloning region. Restrictions of pGprm1 with the asymetrically placed ECORI and ECoRV sites (shown in Figure 16 and sized in Table 19) were used to show that the orientation 
Figure 16. Restriction enzyme digests identifying the $320 \mathrm{bp} \mathrm{Bg} / 1 \mathrm{I}$ fragment cloned into the promoter cloning plasmid pKK232-8 and confirming the orientation of the promoter to be the same as it is in katG. The DNA samples were electrophoresed on polyacrylamide gels and the sizes of the standard fragments used to size the other fragments are given beside the gel. Lane a: DBR322-Haelll; Lane b: pBT22-Bglll; Lane c: pGprm1-Smal/Sall; Lane d:pGprmi-EcoRI; Lane e: pGprm1-Hindlll/ECoRV; Lane f: pBR322-Ncil. 


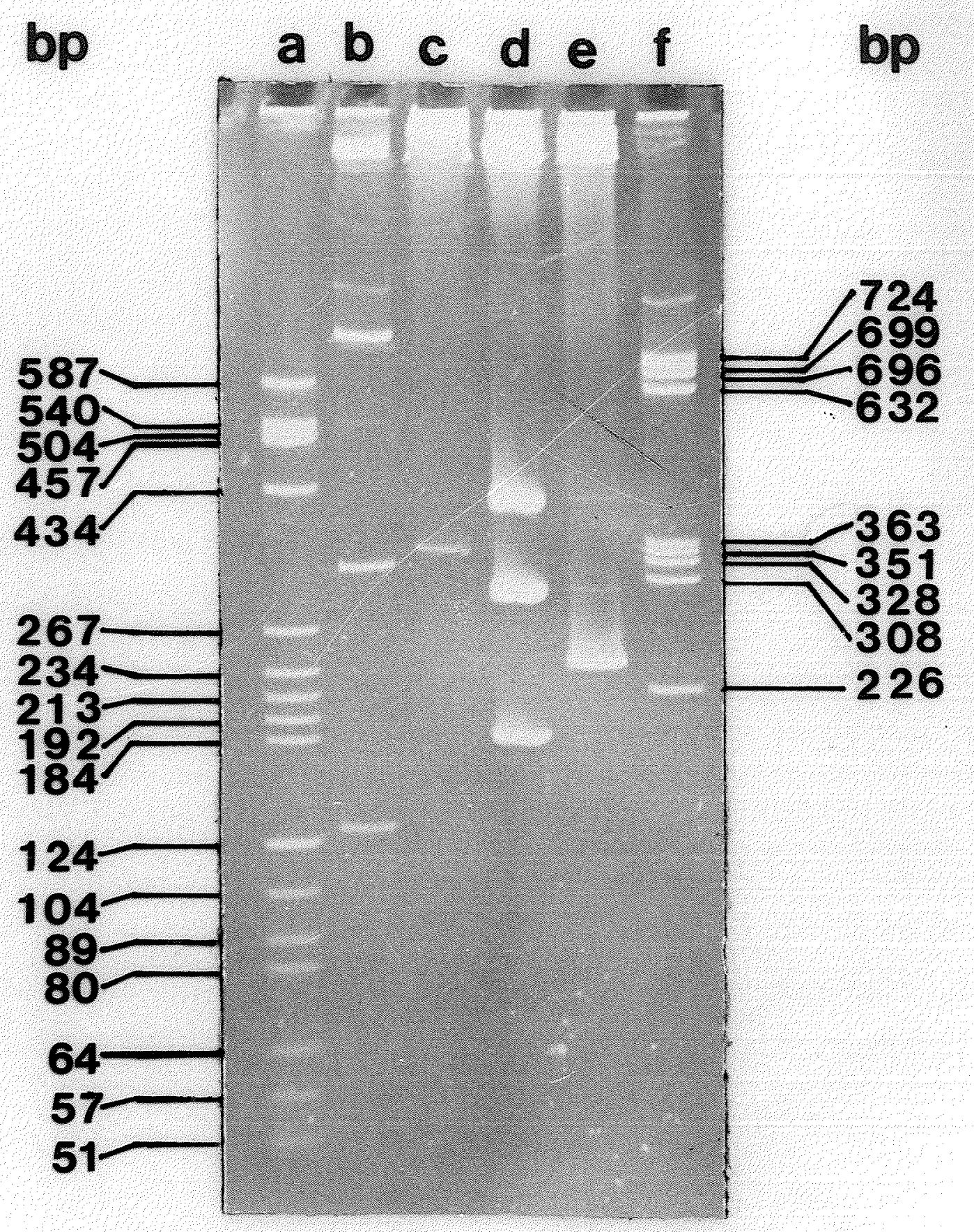


Table 19. Restriction fragments generated from PGprmi

\begin{tabular}{ll}
\hline Enzyme (s) & Fragment size (op) \\
\hline & \\
Smal-Sall & 330 \\
ECoRI & $430 ; 290 ; 180$ \\
HindIII-ECORV & 230 \\
\hline
\end{tabular}


of the $B g / l 1$ fragment was the same in both PBT22 and the promoter cloning plasmid pGprmt. The restriction map of pGprml is shown in Figure 17. pGprm1 was retransformed into UM228 and 60 colonies were picked onto LBC plates to show that all of the colonies were chloramphenicol resistant. Colonies were also picked onto increasing concentrations of chloramphenicol and pGprmi was found to confer resistance to more than $60 \mu \mathrm{g} / \mathrm{mL}$ of choramphenicol.

\subsection{Identification of the Structural Gene for HPI as katG}

The results presented in the previous sections showed that PBT22 contained the structural gene for the E. coli hydroperoxidase, HPI. A transposon Tn10 insertion in the katg locus at 89.2 min was found to prevent the synthesis of the HPI catalase, but the role of katG in this phenomenon was still unclear; katG could be either the structural gene encoding HPI or a gene encoding a regulatory protein affecting HPI synthesis.

The following experiment was designed to answer the question, "was katG the structural gene encoding HPI?" Genomic DNA was prepared from both the wild type E. coli strain MP180, and the kat617: :Tn 10 derivative, UM202. Approximately $2 \mu g$ of each DNA sample was restricted with Hincll and the digests were run on an agarose gel with pBT22 digested by Hincll as a standard at one end and the BRL $1 \mathrm{~kb}$ ladder standard at the opposite end. A Southern blot of the gel was prepared and then Mybridized with nick translated pBT22 DNA under stringent conditions $\left(6 \times S S C, 65^{\circ} \mathrm{C}\right)$. A photograph of the resulting autoradiogram is shown in Figure 18.

The first lane in the autoradiogram contained Hincll restricted 
Figure 17. Restriction map of pGprmi. The thick line represents the vector, PKK232-8 and the thin line represents the insert DNA. Only the restriction sites of interest in mapping the orientation of the Bglll insert have been included (Triggs-Raine and Loewen, 1987). 


$$
\odot
$$


Figure 18. Autoradiogram of the change in hybridization pattern when genomic DNA with or without a transposon Tn10 insertion in katG was digested with Hincll and probed with 32p-labelled pBT22. Lanes A, DBT22 Hincll; B, MP180 genomic DNA digested with Hincll; C, UM2O2 (katG::Tn 10) genomic DNA digested with Hincll; D, BRL $1 \mathrm{~kb}$ ladder molecular weight standard containing some pBR322 fragments which hybridized with the vector portion of PBT22. The numbers along the side indicate the sizes in bp of the known fragments (Triggs-Raine and Loewen, 1987). 


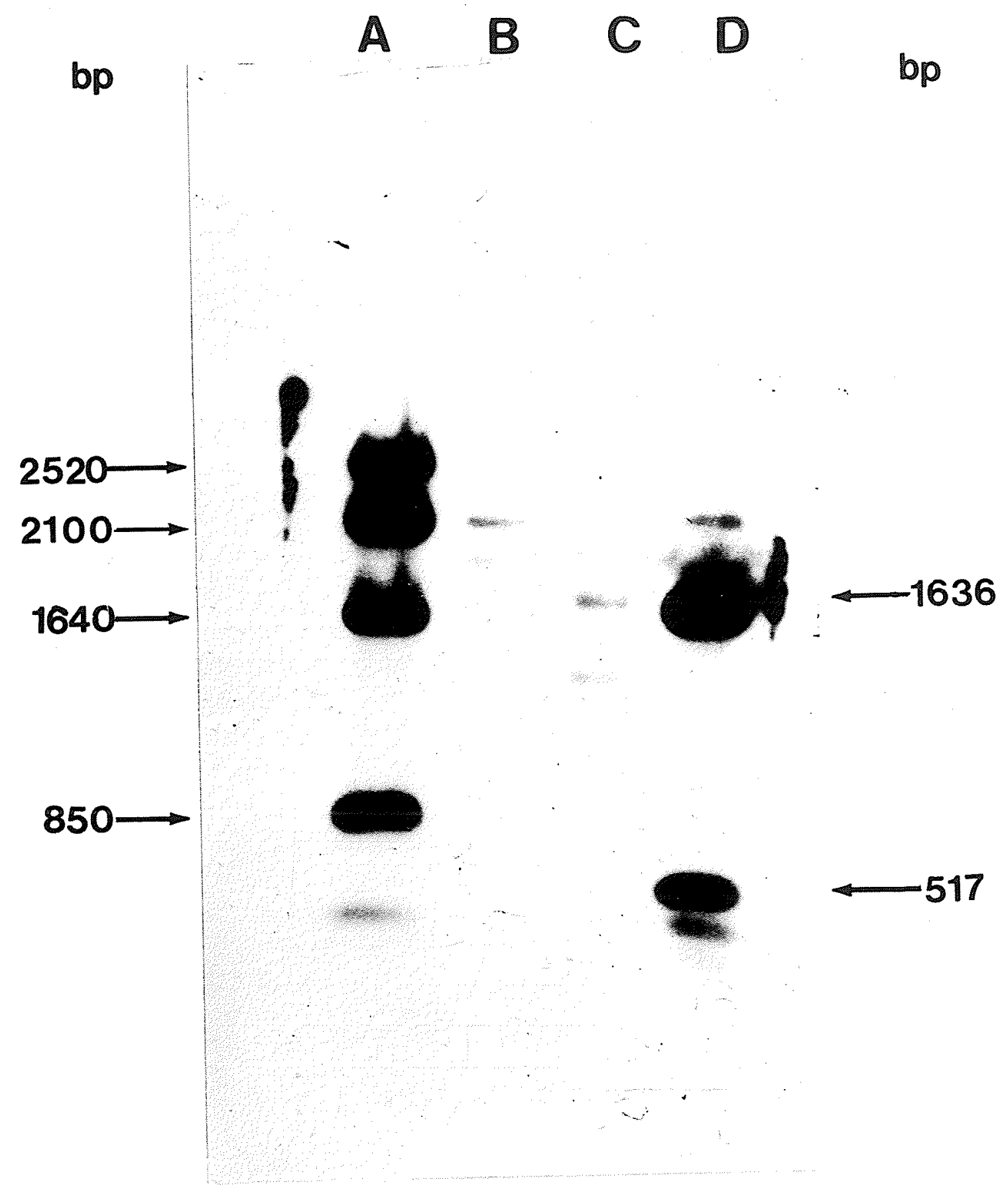


pBT22 DNA probed by itself. Of the five hybridizing bands in this lane, only the second (2100 bp) and the last band (340 bp) are solely composed of pBT22 insert DNA. The first band (2520 bD) was made up of the vector DNA only while the third and fourth bands (1640 bp; 850 bp) were hybrid fragments composed of both vector and insert DNA. Consequently, the bands expected to hybridize in a Hincll digest of genomic DNA included the $2100 \mathrm{bp}$ and $340 \mathrm{bp}$ bands as well as two other bands extending from the Hincll site of the PBT22 insert to the next Hincll site in the $E$. coli genomic DNA. The sizes of these Hincll bands were known to be about 1800 bp and $1350 \mathrm{bp}$ from the restriction mapping of pLC36-19 which contained the genomic DNA surrounding the Hindlll fragment cloned into pBT22.

The second lane in the autoradiogram contained Hincll digested MP180 genomic DNA. The expected bands at $2100 \mathrm{bp}, 1800 \mathrm{bp}$, and $1350 \mathrm{bp}$ were present but the 340 bp fragment could not be seen. This was not surprising since the large fragments were only weakly visible and the small fragment would be expected to show weaker hybridization as was apparent for this band in the first lane. The third band in the hybridization (about $1650 \mathrm{bp}$ ) was not expected, and it is likely that this band resulted from a partial digest between the 1350 bp fragment the neighbouring 100 bp and 340 bp Hincll bands (See Figure 9). This may have resulted because it is often more difficult for restriction enzymes to cut sites which are very close to each other. The fact that this band was not visible in the next lane of UM202 genomic DNA digested by HinclI also suggested that it was the result of a partial digest.

The third lane containing the kat617::Tn 10 derivative of MP180 showed an altered pattern of hybridization. The 2100 bp band composing the majority of the PBT22 insert was absent and was replaced by two new 
bands of about $1700 \mathrm{bp}$ and $1100 \mathrm{bp}$ in size. These fragments add up to more than 2100 bp because they each contain a portion of the $2100 \mathrm{bp}$ fragment and $360 \mathrm{bp}$ of the Tn10 attached to the end. The first Hincll sites in Tn 10 are about 360 bp from each end (Way et al., 1984) (see Figure 19).

The change in the hybridization pattern confirmed that the gene containing the transposon insertion, katG was the same gene that was encoding the HPI protein on PBT22.

\subsection{The Sequencing of KatG and Analys is of This Sequence}

\subsubsection{Sequencing Strategy}

Restriction fragments from pBT22, PBT24, and pBT28 were subcloned into M13mp 18 and M13mp19 for dideoxy chain termination sequencing. The M13 vectors (mp18 and mp19) contain a multiple cloning region (MCR) preceded by a universal primer binding site (see figure 20). The opposite or ientations of the Mefis in these two vectors allow the same inserts to be cloned, but the end of the insert closest to the MCR may vary depending on the vector choice. For instance, if a clone is constructed with the enzymes EcoRI and Hindlll in M13mp18, the Hindlll end of the fragment will be closest to the MCR, while in M13mp 19, the ECORI end will be closest to the MCR. Therefore by selecting the appropriate vector, the end of the fragment where sequencing begins can be controlled. In cases where the vector was cut with only one enzyme, the choice of vector became unimportant because the orientation of fragment insertion could not be controlled.

The sequencing strategy for katG is illustrated in Figure 21 . The sequenced fragments are labelled to allow cross referencing to Table 20 for a description of their construction. The first fragments cloned for 
Figure 19. Restriction map of transposon Tn 10. The thicker lines represent the left and $r$ ight inverted repeat segments of the $9300 \mathrm{bp}$ transposon. The Hincll (H) restriction sites are indicated (Way et al., 1984). 
148

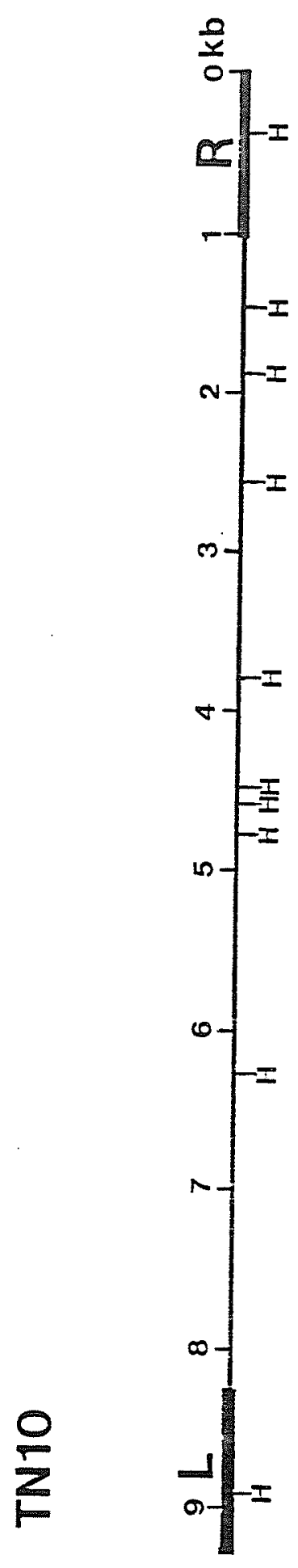


Figure 20. The multiple cloning regions of the M13mp18 and M13mp19 vectors. The order of the restriction sites with reference to the universal primer binding site is shown. 


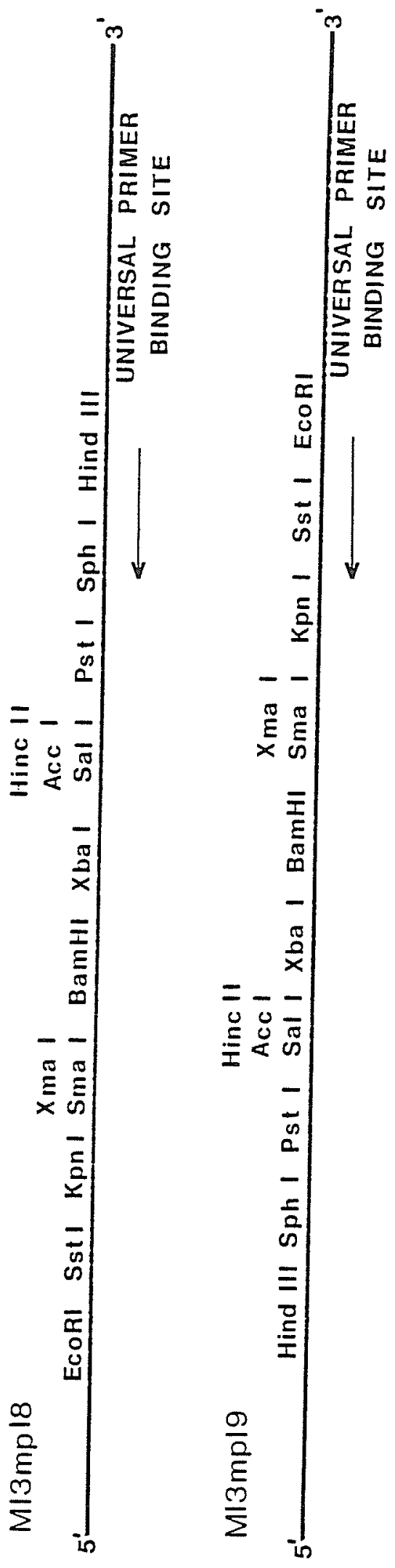


Figure 21. The sequencing strategy of kat6. The origin of the arrows indicate the point at which sequencing began and the arrows point in the direction in which sequencing was done. The letters above the arrows can be cross referenced to Table 20 to see how the clones were constructed. The asterisks indicate the beginning and end of the katG coding region. 


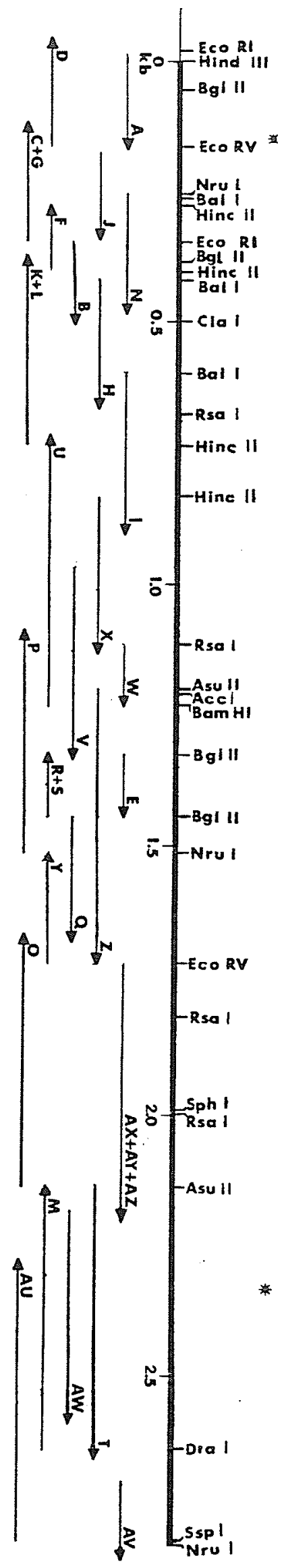


Table 20. Fragments cloned into M13mp18/19 for sequencing kat6

\begin{tabular}{|c|c|c|c|c|}
\hline Fragment & Vector & Enzyme (s) & Insert origin & Enzyme (s) \\
\hline A & $\operatorname{mp} 19$ & ECOR $1-S m a l$ & pBT22 & $E C O R I-E C O R V$ \\
\hline B & $\operatorname{mp} 19$ & $E C O R I-A C C l$ & pBT22 & $E C O R|-C| a \mid$ \\
\hline c & $\mathrm{mp} 19$ & EcoRI-Smal & PBT22 & $E C O R I-E C O R V$ \\
\hline D & $\operatorname{mp} 19$ & Hindl|l-Smal & PBT22 & Hind I II-ECORV \\
\hline$E$ & $m p 19$ & BamHI & pBT22 & $B g \|$ \\
\hline $\mathrm{F}$ & $\operatorname{mp} 19$ & Hinc $\mid 1$ & PBT22 & Hincll \\
\hline$G$ & $\operatorname{mp} 19$ & ECORI-HindIII & рВT22 & ECORI-HindIII \\
\hline$H$ & $\operatorname{mp} 18$ & BamHI-Hincl| & pBT24 & $B a m H I-B a \|$ \\
\hline 1 & $m p 18$ & BamHl-Hincll & PBT24 & $B a m H I-B a \|$ \\
\hline J & $\mathrm{mp} 18$ & BamHI-Hincll & PBT22 & $B a m H I-E C O R V$ \\
\hline k & $\mathrm{mp} 18$ & BantHI-Hinc|I & PBT22 & BamHI-Hind III \\
\hline$L$ & $\mathrm{mp} 19$ & Hinel| & PBT22 & Hincll \\
\hline M & $\mathrm{mp} 19$ & $A C C l-S m a l$ & pBT22 & Dral-Asull \\
\hline$N$ & $\mathrm{mp} 19$ & Smal & PBT22 & Nrul \\
\hline 0 & $\mathrm{mp} 19$ & Hind ||$-A C C \mid$ & DBT22 & Asul1-Hindl। \\
\hline$P$ & $\mathrm{mp} 19$ & Smal & DBT22 & Nrul \\
\hline$Q$ & mp 19 & BamHI-Hinc|I & PBT22 & $B g \| 1-E C O R V$ \\
\hline$R$ & $\mathrm{mp} 18$ & BamHI-Hincll & PBT22 & $B g\|\|-E C O R V$ \\
\hline$s$ & $\operatorname{mp} 19$ & BamHI & PBT22 & $B g \|$ \\
\hline $\mathrm{T}$ & $\operatorname{mp} 19$ & ACCl-Hind || & PBT22 & Asul|-Hindl $\mid 1$ \\
\hline$u$ & mp 19 & BamHI-Hincli & PBT24 & $B a m H|-B a| l$ \\
\hline v & $\operatorname{mp} 18$ & BamHI-Hincli & DBT24 & Bg $\| I-E C O R V$ \\
\hline$w$ & $\operatorname{mp} 18$ & BamHI-Hincll & PBT22 & BamHI-Rsal \\
\hline$x$ & $m p 18$ & BamHI-Hincll & pBT28 & BamHI-Hincll \\
\hline$Y$ & $m p 18$ & BamHI-Hincl| & PBT22 & $B g \| \mid-E C O R V$ \\
\hline$Z$ & $\operatorname{mp} 19$ & $A C C l$ & pBT22 & Asul 1 \\
\hline$A U$ & $\operatorname{mp} 19$ & $A c c l-S m a l$ & pBT22 & Sspl-Asul| \\
\hline AV & $\mathrm{mp} 19$ & BamHI & PBT22 & $\operatorname{san} 3 A$ \\
\hline AW & $\operatorname{mp} 19$ & Smal & PBT22 & Haell \\
\hline$A X$ & $\operatorname{mp} 19$ & Smal & pBT22 & ECORV \\
\hline AY & $\operatorname{mp} 19$ & Smal-HindIII & pBT22 & HindIII-ECORV \\
\hline$A Z$ & $\operatorname{mp} 18$ & BamHI-Smal & PBT22 & $B g \||-S s p|$ \\
\hline
\end{tabular}


sequencing were $B g / 11$ and Hincll fragments. To determine if the clones Gontained insert LNA from pBTaz, the RF ONA was prepared from all of the clones, run on an agarose gel, southern blotted, and hybridized with nick translated PBT22. All of the cloned Bglll fragments hybridized, indicating that they did contain inserts from DBT22, but there were several Hincll clones that did not hybridize. It was found that Hincll was a poor choice for restricting the vector because it appeared to contain a contaminating exonuclease which resulted in many white plaques containing no insert DNA. In the subsequent cloning procedures, the presence of PBT22 DNA in the recombinant M13 was not confirmed by hybridization. Two of the cloned fragments, $M$ and $A Y$, had been cut from an agarose gel, purified, and cloned. The Sau3A (AV) and Haelll (AW) clones were selected by cloning all possible fragments from pBTaa, then hybridizing the RF DNA with the large 2100 bp Hincll fragment of pBT22, which had been cut from an agarose gel, purified, and nick translated. single stranded DNA was prepared from a number of white plaques from each cloning experiment. All of the clones were T-tracked unless specific clones of interest had been identified by hybridization and in these instances only selected clones were T-tracked. Selection of clones for sequencing from the T-tracks was straightforward if part of the sequence of the same or the opposite strand was already known. If the sequence was unknown, and more than one type of clone was expected in the experiment, the following guidel ines were helpful. The smallest DNA fragment greater than 100 bp in size normally cloned with the highest frequency and should therefore be the most common T-track. Small white plaques were often associated with very large inserts and they also had decreased yields of SsDNA which appeared as a light T-track. 
Finally, vector deletions containing no insert DNA were common and the T-tracks were always examined for vector sequence.

The entire region between the Hindlll site at the start of the PBT22 insert and the Dral site, 2624 bp into the insert was sequenced in both directions (Figure 23). All of the restriction sites were overlapped to be sure that no small pieces of sequence were missed. Sequence beyond the Dral site was not determined in both directions but it is included in a subsequent section in the interest of future research in the areas surrounding this gene.

\subsubsection{The katG DNA Sequence}

The sequence of the 2624 bp portion of PBT22, determined using the strategy in Figure 21, corresponded well with the restriction enzyme map previously generated for PBT22. Only one restriction site, Clal at 499 bp was not identified by restriction enzyme digestion. This site was probably not found because the clal restriction site, 5'ATCGAT3', may not be recognized if the underlined A residue is methylated (Mayer et al., 1981).

The 2624 bp sequence contained only one open reading frame large enough to encode the HPI protein. The open reading frame started at base 146 with an ATG triplet specifying methionine and extended for 726 amino acids until it was ended by a TAA codon at $2326 \mathrm{bp}$. The DNA sequence between nucleotides 655 and 723 is shown in Figure 22 as an example of the DNA sequencing and interpretation. The entire DNA sequence is presented in Figure 23 with its predicted amino acid sequence underneath.

The katG DNA sequence was compared to the GenBank (1986) of DNA sequences as well as to yeast catalase $T$ using the computer program, 
Figure 22. Photograph of a portion of an autoradiogram of a sequencing gel. This sequence was obtained from clone 1 and allows the nucleotide sequence between bases 655 to 723 of the katG sequence to be read by reading from the bottom to the top of the photograph. The $A, C, G$, and $T$ tracks are labelled above the lanes. The sequence reading from bottom to top is 5'GCTAGAAAACTCC GGCTTCCGTACCTTCGGTTTTGGTGCCGGTCGTGAAGACGTCTGGGAACCGGATCT 3'. 


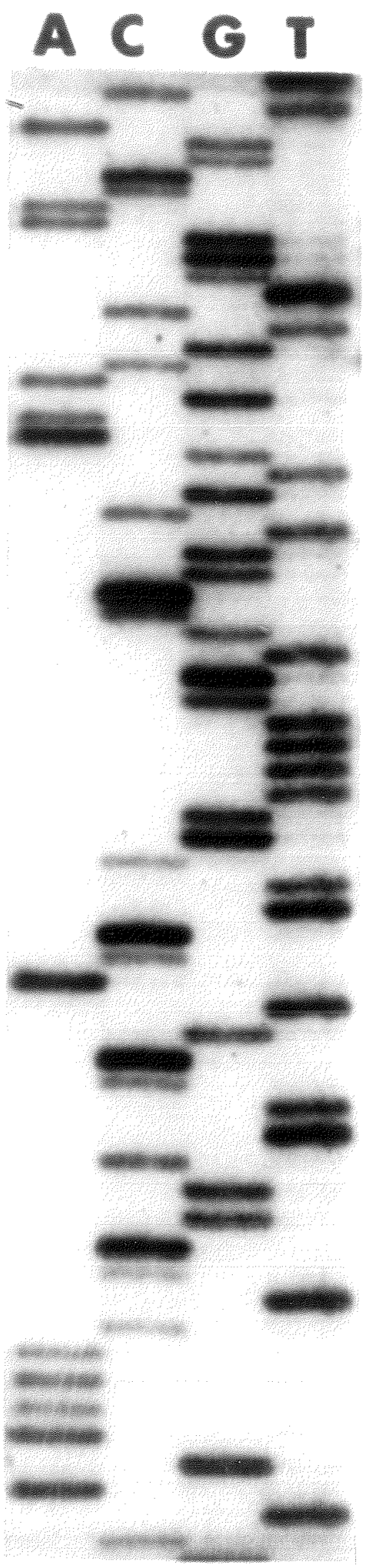


Figure 23. The katG DNA sequence and the HPI predicted amino acid sequence. Numbers on the $r$ ight hand side of the sequence specify the nucleotide number and those on the left hand side specify the amino acid number. Restriction sites relevant to the material presented in this thesis are italicized and labelled. Amino acids confirmed by direct sequencing of the purified HPI protein are underlined and in boldface print. A potential promoter ( -35 and -10) sequence, Shine-Dalgarno sequence, and terminator sequence are emphasized in darker type. 
Hindl11 28 AAGCTTAATTAAGATCAATTTGATCTAC

$B g 111$ 100 ATCTCTTTAACCAACAATATGTAAGATC TCAACTATCGCATCCGTGGATTAATTCAATTATAACTTCTCTCT AACGCTGTGTATCGTAACGgTAACACTGTAGAGgGgagCACATTGATGAGCACGTCAGACGATATCCATAAC $M S S T S C D$ I H N 244 ACCACAGCCACTGGCAAATGCCCGTTCCATCAGGGCGGTCACGACCAGAGTGCGGGGGCGGGCACAACCACT $\begin{array}{cllllllllllllllllllllllll}T & T & A & T & G & K & C & P & F & H & Q & G & G & H & D & Q & S & A & G & A & G & T & T & T\end{array}$ 10

Nrul Ball 316 CGCGACTGG TGGCCAAATCAACTTCGTGTTGACCTGTTAAACCAACATTCTAATCGTTCTAACCCACTGGGT $\begin{array}{rlllllllllllllllllllllllll}R & D & W & W & P & N & Q & L & R & V & D & L & L & N & Q & H & S & N & R & S & N & P & L & G\end{array}$ 34 ECORI BgIII 388 GAGGACTTTGACTACCGCAAA GAATTCAGCAAATTAGATTACTACGGCCTGAAAAAAGATCTGAAAGCCCTG $\begin{array}{rllllllllllllllllllllllllll}E & D & F & D & Y & R & K & E & F & S & K & L & D & Y & Y & G & L & K & K & D & L & K & A & L\end{array}$ Hincll Ball 460 TTGACAGAATCTCAACCGTGG TGGCCAGCCGACTGGGGCAGTTACGCCGGTCTGTTTATTCGTATGGCCTGG $\begin{array}{llllllllllllllllllllllll}L & T & E & S & Q & P & W & W & P & A & D & W & G & S & Y & A & G & L & F & I & R & M & A & W\end{array}$ 82

Clal 532 CACGGCGCGGGGACTTACCGTTCAATCGATGGACGCGGTGGCGCGGGTCGTGGTCAGCAACGTTTTGCACCG $H$
106 BaIl 604 CTGAACTCCTGGCCGGATAACGTAAGCCTCGATAAAGCGCGTCGCCTGTTG TGGCCAATCAAACAGAAATAT

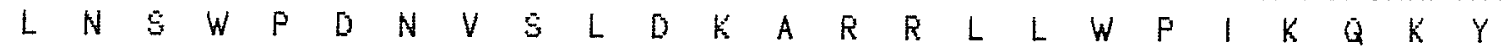
130

676

GGTCAGAAAATCTCCTGGGCCGACCTGTTTATCCTCGCGGGTAACGTGGCGCTAGAAAACTCCGGCTTCCGT

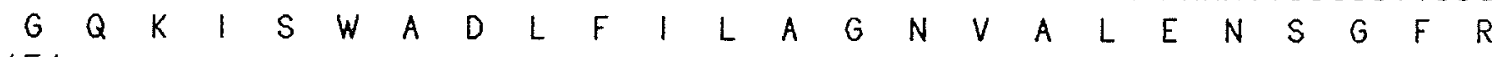
154

Rsal Hincll 748 ACCTTCGGTTTTGGTGCCGGTCGTGAAGACGTCTGGGAACCGGATCTGGATGTTAACTGGGGTGATGAAAAA $\begin{array}{llllllllllllllllllllllll}T & F & G & F & G & A & G & R & E & D & V & W & E & P & D & L & D & V & N & W & G & D & E & K\end{array}$ 178

GCCTGGCTGACTCACCGTCATCCGGAAGCGCTGGCGAAAGCACCOCTGOGTGCAACCGAGATGGGTCTGATT $\begin{array}{lllllllllllllllllllllllllllll}A & W & L & T & H & R & H & P & E & A & L & A & K & A & P & L & G & A & T & E & M & \underline{G} & L & L & 1\end{array}$ 202

Hincll 892 TAC GTTAACCCGGAAGGCCCGGATCACAGCGGCGAACCGCTTTCTGCGGCAGCAGCTATCCGCGCGACCTTC

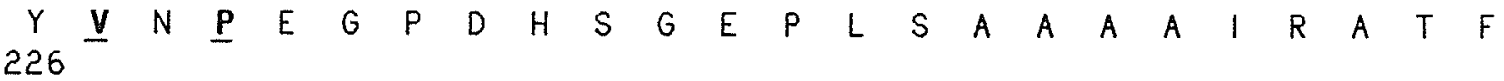

964 GGCAACATGGGCATGAACGACGAAGAAACCGTGGCGCTGATTGCGGGTGGTCATACGCTGGGTAAAACCCAC 650
25 
GGTGCCGgTCCGACATCAAATGTAGGTCCTGATCCAGAAGCTGCACCGATTGAAGAACAAGGTTTAGGTTGG

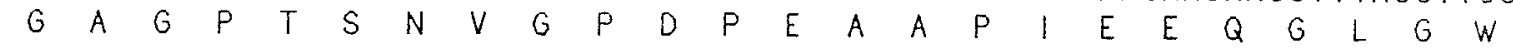
274

1108

GCGAGCACTTACGGCAGCGGCGTTGGCGCAGATGCCATTACCTCTGGTCTGGAAGTAGTCTGGACCCAGACG

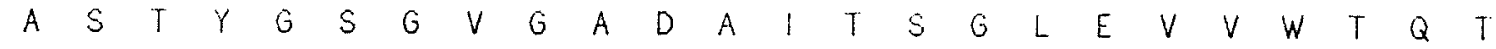
298

Rsal 1180

CCGACCCAGTGGAGCAACTATTTCTTCGAGAACCTGTTCAAGTATGAGTGGGTACAGACCCGCAGCCCGGCT $\begin{array}{lllllllllllllllllllllllll}P & T & Q & W & S & N & Y & F & F & E & N & L & F & K & Y & E & W & V & Q & T & R & S & P & A\end{array}$ 322

AsUII ACCI BamHI 1252 GGCGCAATCCAG TTCGAAGCG GTAGACGCACCGGAAATTATCCC GGATCCGTTTGATCCGTCGAAGAAACGT

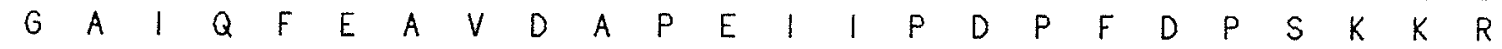
346

$B g \| 1324$ AAACCGACAATGCTGGTGACCGACCTGACGCTGCGTTTTGATCCTGAGTTCGAGAAGATCTCTCGTCGTTTC $\begin{array}{lllllllllllllllllllllllll}K & P & T & M & L & V & T & D & L & T & L & R & F & D & P & E & F & E & K & I & S & R & R & F\end{array}$ 370

1396

CTCAACGATCCGCAGGCGTTCAACGAAGCCTTTGCCCGTGCCTGGTTCAAACTGACGCACAGGGATATGGGG

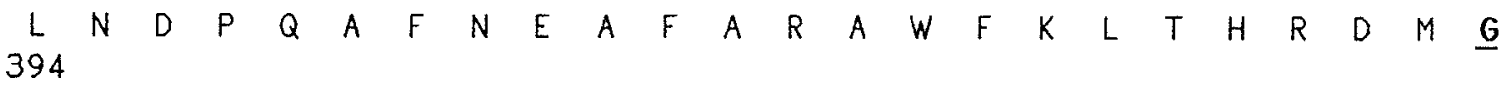

$B g \|||$

1468

CCGAAATCTCGCTACATCGGGCCGGAAGTGCCGAAAGAAGATCTGATCTGGCAAGATCCGCTGCCGCAGCCG

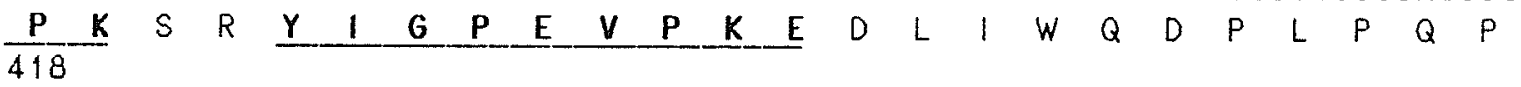
Clal Nrul 1540 ATCTACAACCCGACCGAGCAGGACATTATCGATTGGAAT TCGCGATTGCGGATTCTGGTCTGTCTGTTAGT $\begin{array}{llllllllllllllllllllllll}I & Y & N & P & T & E & Q & D & I & \mid & D & L & K & F & A & I & A & D & S & G & L & S & V & S\end{array}$ 442

1612 GAGCTGGTATCGGTGGCCTGGGCATCTGCTTCTACCTTCCGTGGTGGCGACAAACGCGGTGGTGCCAACGGT

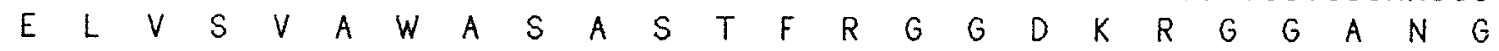
466

1684 GCGCGTCTGGCATTAATGCCGCAGCGCGACTGGGATGTGAACGCCGCAGCCGTTCGTGCTCTGCTTGTTCTG $\begin{array}{lllllllllllllllllllllllll}A & R & L & A & L & M & \underline{P} & Q & R & D & W & D & V & N & A & A & A & V & R & A & L & L & V & L\end{array}$ 490

$$
\text { ECORV } 1756
$$

GAGAAAATCCAGAAAGAGTCTGGTAAAGCCTCGCTGGCG GATATCATAGTGCTGGCTGGTGTGGTTGGTGTT $\begin{array}{clllllllllllllllllllllll}E & K & \text { I } & Q & K & E & S . . G & K & A & S & L & A & D & I & 1 & V & L & A & G & V & V & G & V\end{array}$ 514

Rsal

1828

GAGAAAGCCGCAAGCGCCGCAGGTTTGAGCATTCAT GTACCGTTTGCGCCGGGTCGCGTTGATGCGCGTCAG $E$
538 1900 GATCAGACTGACATTGAGATGTTTGAGCTGCTGGAGCCAATTGCTGACGGTTTCCGTAACTATCGCGCTCGT $\begin{array}{lllllllllllllllllllllllllll}D & Q & T & D & I & E & M & F & E & L & L & E & P & I & A & D & G & F & R & N & Y & R & A & R\end{array}$ 562 
CTGGACGTTTCCACCACCGAGTCACTGCTGATCGACAAAGCACAGCAACTGACGCTGACCGCGCCGGAAATG

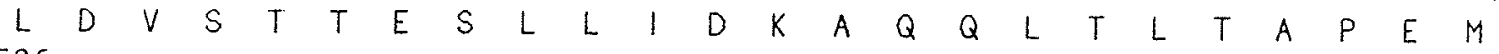
586

Sphl Rsal 2044 ACTGCGCTGGTGGGCG GCATGCGTGTACTGGGTGGCAACTTCGATGGCAGCAAAAACGGCGTCTTCACTGAC $\begin{array}{lllllllllllllllllllllllll}T & A & L & V & G & G & M & R & V & L & \underline{G} & A & N & F & \mathbb{D} & \mathbf{G} & \mathbf{S} & K & N & G & V & F & T & D\end{array}$

CGCGTTGGCGTATTGAGCAATGACTTCTTCGTGAACTTGCTGGATATGCGTTACGAGTGGAAAGCGACCGAC

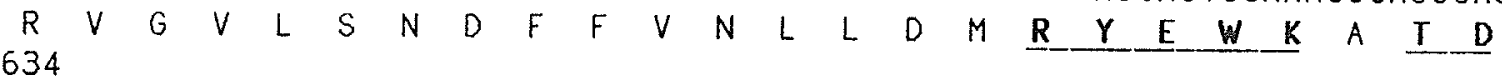

Asull Haell1 2188

GAATCGAAAGAGCTG TTCGAAGGCCGTGACCGTGAAACCGGCGAAGTGAAATTTAC GGCCAGCCGTGCGGAT

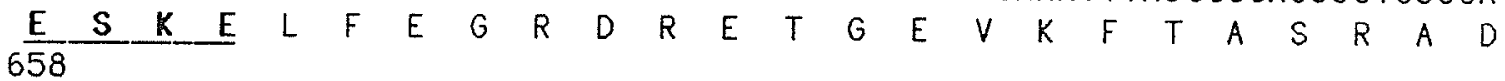
2260 CTGGTGTTTGGTTCTAACTCCGTCCTGCGTGCGGTGGCGGAAGTTTACGCCAGTAGCGATGCCCACGAGAAG

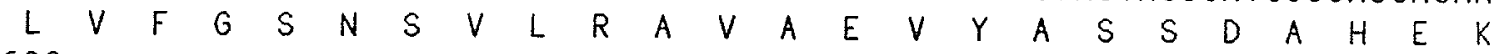
682 TTTGTTAAAGACTTCGTGGCGGCATGGGTGAAAGTGATGAACCTCGACCGTTTCGACCTGCTGTAATCTGAC $\begin{array}{lllllllllllllllllllllll}F & V & K & D & F & V & A & A & W & V & K & V & M & N & L & D & R & F & D & L & L & E N D\end{array}$ 706

2404 CCCGTTCAGCGGCTGCTTGCTGGCAGTCGCTGAACGTTCTTTACCAGCGTATAGTGGGCGAACGAAAACTAC

2476 ACACTGGATCTCTCATGTCTGCCGCAGGAAAGAGCAACCCACTGGCAATCAGTGGCCTGGTTGTGCTCACAC TTATCTGGAGTTATAGCTGGATTTCATGAAGCAAGTCACCAGTTACATCGGTGCCTTCGACTTTACCGCCTT ACGCTGCATTTTCGGCGCTCTCGTTTTATTCATCGTCCTTTTATTACGTGGTCGCGGAATGCGCCCGACACC 
Microgenie. No homologous sequences were found, confirming this sequence to be novel. The DNA sequence of both kat $G$ and the surrounding region was compared to the sequence of oxyR (Gisela Storz, personal communication) but no homology with this sequence was identified.

\subsubsection{Control Sequences of the katG Gene}

Sequences typical of E. coli transcriptional and translational control elements were found in close proximity to the katG coding sequence. The potential control sequences presented in this section are illustrated in Figure 24 with the appropriate E. coli consensus sequences for comparison.

As discussed in section 2.11, sequences upstream from the point of transcription initiation are required for RNA polymerase binding. These include the $\mathrm{Pr}$ ibnow box or -10 sequence (TATAAT) and the -35 sequence (TTGACA) which are normally separated by 16-18 bp. Initiation of transcription often occurs at an A that may be the central base of a CAT triplet 5-9 bp downstream from the -10 sequence (Harley and Reynolds, 1987). Although the transcriptional start site of the katG mRNA had not been experimentally determined, the promoter was known to be within the 322 bp Bglll fragment previously shown to contain the promoter. Using the $6 g / 11$ site at 55 bp and the protein start codon at 146 bp as boundaries, the sequence showing the best homology to the promoter consensus sequence was found to start $75 \mathrm{bp}$ into the sequence. A potential -35 sequence of TTATAA was located 18 bp upstream from a potential -10 sequence of TATCGT which in turn was located 9 bp upstream of an A residue centred in a CAC triplet. These sequences fit well with the consensus sequences, having all of the highly conserved nucleotides, (bases conserved in more than $75 \%$ of $E$. coli promoter sequences, [Harley 
Figure 24. The control sequences of the katG gene.

a) Promoter sequence. The potential katG promoter sequence is shown below the $E$. coli consensus promoter sequence with dashed lines connecting the conserved bases. The portion of the $E . \mathrm{col} i$ consensus sequence which is weakly conserved is represented by small letters, while that which is strongly conserved is represented by capital letters. The starting nucleotide of the katG sequence shown in this figure is numbered on the left hand side. The asterisk denotes the base at which transcription is expected to start.

b) Shine-Dalgarno Sequence (SDS). The potential katG ShineDalgarno sequence is shown below the $E$. coli consensus sequence and the conserved bases are connected with slashed lines. The first nucleotide of the katG sequence is numbered on the left hand side. c) The Termination Sequence. A potential rho independent termination sequence for the kat 6 gene is shown with the secondary structure the RNA would be expected to form underneath. The palindromic portion of the sequence in underlined and the first nucleotide shown of the katG sequence is numbered on the left hand side. 
(a) Promoter Sequence

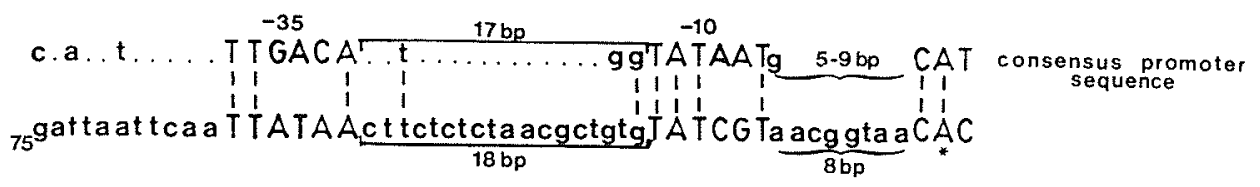

(b) Shine-Dalgarno Sequence

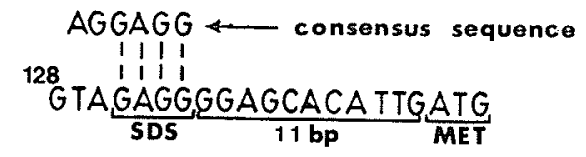

\section{(c) Termination Sequence}

2321 CTGTAATCTGACCCCGTTCAGCGGCTGCT TGCTGGCAGTCGCTGAACGTTCTTT LEU END

PALINDROMIC SEQUENCE

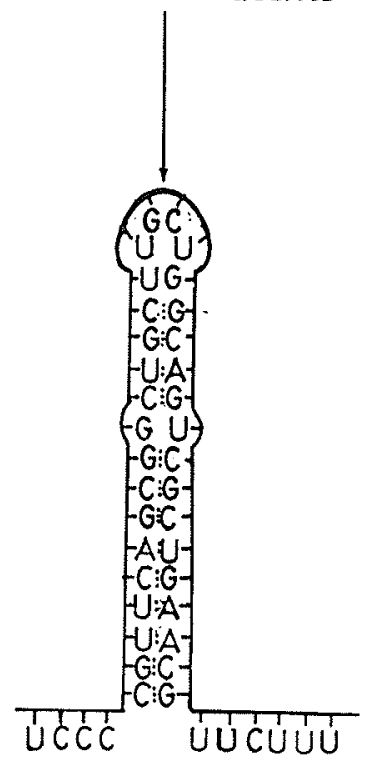


and Reynolds, 1987]) conserved in this sequence. This included the two T's in the -35 sequence and the TA... T portion of the -10 sequence. An A was identified as a potential transcription start point 8 bp downstream from the -10 sequence, centred in a CAC triplet which showed good homology to the CAT triplet which has been weakly associated with transcriptional start points (Harley and Reynolds, 1987). Weakly conserved bases (occuring in $37 \%$ or less of E. coli promoters, [Harley and Reynolds, 1987]) are also shown in Figure 24. Two of these seven bases are conserved in the potential kat 6 promoter.

A consensus sequence complementary to the $3^{\prime}$ end of the 165 rRNA, called the Shine-Dalgarno sequence, is required for translational initiation. This consensus sequence of $A G G A G G$ is found $3-12$ bp before the first amino acid of the protein (Glover, 1984). A 9 bp polypurine region containing a sequence homologous to the Shine-Dalgarno consensus sequence was found 11 bp upstream of the initiating methionine of the HPI protein (see figure 24). The sequence surrounding the potential shineDalgarno sequence in Figure 23 forms a hyphenated dyad of CACTGT-ACATTG with a 1 bp mismatch. The purpose of this potential pairing sequence is unknown since Ganoza et al. (1987) have found that most sequences 5 ' to the start codon have little pairing potential as this would likely interfere with translation.

E.coli transcriptional termination sequences show no real consensus sequence at a primary level but they do have consensus at the level of secondary structure. All E. coli termination sequences contain a palindromic sequence, often 6-C rich, which could allow stable base pairing of the resulting mRNA. Termination may be rho dependent or independent, but typically the hyphenated dyads of rho independent 
terminators are followed by a polyT tail (Rosenberg and Court, 1979). The kato sequence has a potential rho independent terminator consisting of a 14 bp hyphenated dyad 8 bp beyond the end of the coding sequence followed by a 6 bp stretch containing 5 U's. The palindrome contains only a single base mismatch and a predominance of GC bases which would allow stable stem and loop formation as shown by the model in Figure 24. Based on the calculations of Borer et al. (1974), a stability of $\Delta G=-21.4 \mathrm{kcal}$ can be calculated confirming the extreme stability of the palindrome. Termination of the RNA transcript always occurs $16-24$ bp downstream from the center of the hyphenated dyad (Rosenberg and court, 1979). The kato mRNA would be expected to terminate between base 2367 and 2375 in Figure 23.

\subsubsection{Confirmation of the Predicted HPI Amino Acid Sequence}

\subsubsection{Sequencing of Cyanogen Bromide Peptides from HPI}

To confirm the 726 amino acid sequence predicted for the HPI protein a portion of the HPI amino acid sequence had to be determined. Two attempts to sequence the $N$-terminus of the protein were unsuccessful, suggesting that the $\mathrm{N}$-terminus was blocked as a result of some type of modification. The identity of the blocking group was unknown, but N-terminal blocking groups have been reported in bovine liver catalase. The group blocking the $N$-terminus of bovine liver catalase has not been identified even with the help of x-ray crystallography and positive and negative ion mass spectrometry (Schroeder et al., 1982a).

Peptides with amino termini accessible for amino acid sequencing were generated by cyanogen bromide cleavage of the HPI protein. Six peptides labelled $|a| c, 3,,1 \mid 1,4$ and $\mid V$, were sequenced, and the amino acids were identified in as many reaction cycles as possible (see Table 
21). From the six sequenced HPLC peaks, seven polypeptide sequences were identified in the HPI predicted sequence. The extra identifiable polypeptide was the result of a mixture of polypeptides in peak IV which were separable into two peptide sequences based on knowledge of the DNA sequence.

The amino acids in Table 21 which confirm portions of the predicted HPI sequence are underlined as are the confirmed portions of the HPI predicted sequence in Figure 23. Unfortunately, the small quantity of the peptides and the presence of more than one polypeptide in some of the peaks made the amino acid sequence difficult to interpret. Specifically, amino acids which were of low yield during the final hydrolysis in the reaction, serine and threonine, were particularly difficult to identify. Amino acids which did not confirm the predicted amino acid sequence were rechecked and in many cases the inconsistencies could be accounted for. In no instance where there were inconsistencies unaccounted for was there any evidence that the predicted sequence was incorrect.

The identification of all the peptides in the HPI sequence confirmed that the reading frame was correct. Although there were some differences between the peptide sequences and the predicted amino acid sequence, the fact that amino acids could be confirmed in cycles following the inconsistencies showed that the reading frame was correct.

\subsubsection{Molecular Weight Determination and Amino Acid Composition}

The molecular weight of the predicted HPI sequence was calculated to be 80 049, consistent with the relative molecular weights of 84000 (Loewen et al., 1985b) and 78000 (Claiborne and Fridovich, 1979) estimated by SDS-PAGE. 
Table 21. Amino acid sequence of cyanogen bromide generated peptides of $\underline{\text { HPI }}$

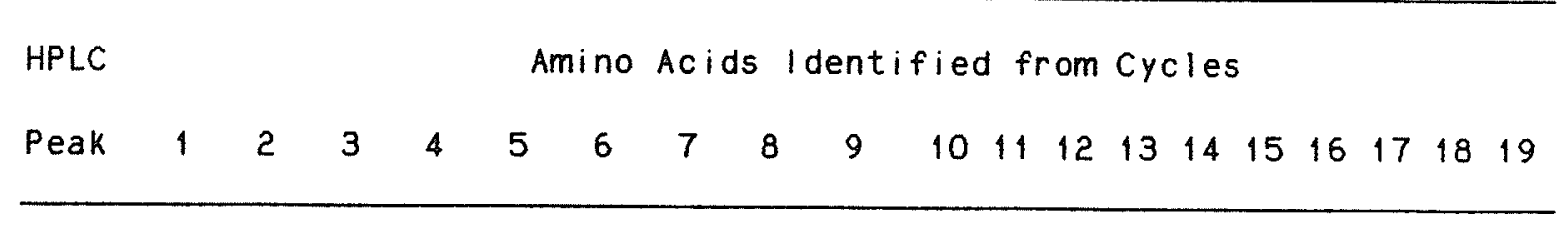

$$
\begin{aligned}
& \begin{array}{llllllllllll}
\text { la } & G & R & F & \underline{G} & \underline{A} & \underline{G} & P & \underline{Y} & G & P & \frac{1}{K}
\end{array}
\end{aligned}
$$

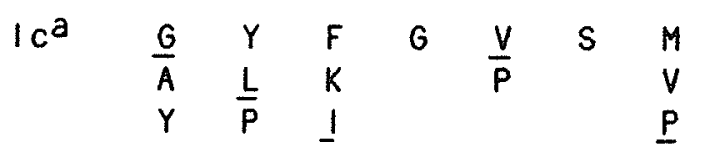

$$
\begin{aligned}
& \begin{array}{lllllllllllll}
3-M^{b} & \frac{R}{S} & \underline{Y} & \frac{E}{N} & G & F & G & T & \underline{D} & G & \underline{S} & \frac{K}{E} & \underline{E} \\
3-m^{C} & G & N & T & W & \frac{K}{V} & P & P & Y & K & P & P & - \\
& & & & & A & E & N & & I & & & \\
& & & & & & V & E & & F & & & \\
& & & & & & & & & &
\end{array} \\
& \begin{array}{lllllllllllll}
|1|-M & S & Y & N & \underline{G} & F & G & T & \underline{D} & \underline{G} & \underline{S}^{d} & \frac{K}{1} & \underline{E}
\end{array} \\
& \begin{array}{lllllllllllll}
I \mid 1-m & G & N & T & W & V & P & P & Y & K & P & P & - \\
& A & E & N & & I & & & \\
& & & & V & E & & F & & & \\
& & & & & & & & & & & &
\end{array} \\
& \begin{array}{llllllllllllllllllll}
4 & \mathbb{N} & D & E & E & I & \underline{V} & \underline{A} & \underline{L} & I & A & \underline{G} & \underline{G} & \underline{H} & I & L & \underline{G} & K & I & H
\end{array}
\end{aligned}
$$

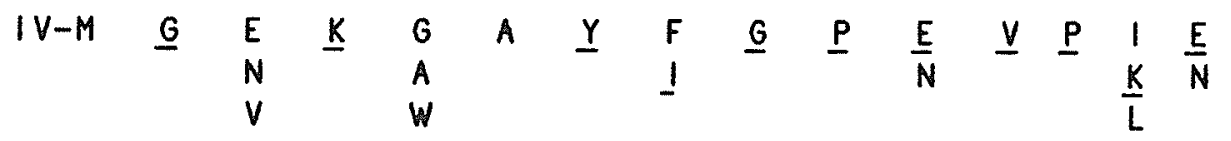

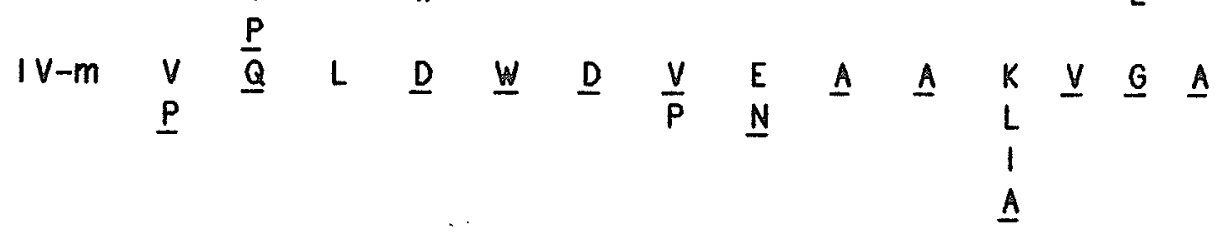

a extra tyrosine present throughout the analysis

b major amino acids

c minor amino acids

d extra alanine present

All amino acids confirming the HPI predicted sequence are under lined * Cycles where a) more than one amino acid was identified in cycles if more than one amino acid was abundant in comparison to the previous cycle and/or where b) the amino acid peak in the cycle could be one of two or three amino acids having similar residence times. 
The amino acid composition of the predicted HPI sequence is shown in Table 22 with the amino acid compositions previously determined for HPI catalase (Claiborne and Fridovich, 1979) and bovine liver catalase (Schroeder et al., 1982). Fridovich's determination of the HPI amino acid composition was relatively consistent with that of the predicted HPI protein. There were obvious differences in the serine, threonine, aspartate/asparagine and tryptophan values. The method of determination of the serine and threonine values could explain their difference. Because serine and threonine are destroyed during the hydrolysis of the protein in preparation for the determination of the amino acid composition, serine and threonine content must be determined at various times of hydrolysis and then the original content determined by extrapolation back to zero time. Tryptophan content must also be determined separately, which could have led to the high value. The reason for the low aspartate/asparagine value is unknown.

The amino acid composition of the HPI protein was also compared to the bovine liver catalase amino acid composition. The compositions were similar, but there were some notable differences. The histidine and tyrosine content was much higher in the bovine liver catalase, while the alanine and leucine content was much higher in the HPI protein.

\subsubsection{Codon Usage in katG}

Codon usage is organism specific, reflecting the isoaccepting tRNA 
Table 22. Amino acid composition of catalase proteins.

\begin{tabular}{|c|c|c|c|c|c|}
\hline \multirow[t]{2}{*}{ Amino Acid } & \multicolumn{2}{|c|}{$\begin{array}{l}\text { Predicted HPI } \\
\text { Sequence }\end{array}$} & \multicolumn{2}{|c|}{$\begin{array}{c}\text { Fridovicha } \\
\text { HPI }\end{array}$} & \multirow{2}{*}{$\begin{array}{c}\text { Bovine Liverb } \\
\text { Catalase } \\
\%\end{array}$} \\
\hline & \# & $\%$ & \# & $\%$ & \\
\hline Lysine & 35 & $(4.8)$ & 38.4 & $(5.1)$ & 5.3 \\
\hline Histidine & 13 & $(1.8)$ & 8.9 & $(4.3)$ & 4.0 \\
\hline Arginine & 44 & $(5.6)$ & 44.5 & $(5.9)$ & 6.4 \\
\hline Aspartic AcidC & 83 & $(14.5)$ & 57.7 & $(7.7)$ & 13.6 \\
\hline Threonine & 39 & $(5.4)$ & 27.6 & $(3.7)$ & 4.3 \\
\hline Serine & 44 & $(6.1)$ & 100.1 & $(13.3)$ & 4.9 \\
\hline Glutamic Acide & 68 & $(9.4)$ & 77.2 & $(10.3)$ & 9.1 \\
\hline Proline & 39 & $(5.4)$ & 38.8 & $(5.2)$ & 7.5 \\
\hline Glycine & 65 & $(8.9)$ & 60.7 & $(8.1)$ & 6.7 \\
\hline Alanine & 77 & $(10.6)$ & 67.8 & $(9.0)$ & 6.9 \\
\hline Cysteine & 1 & $(0.1)$ & 0 & $(0.0)$ & 0.8 \\
\hline Valine & 43 & $(5.9)$ & 46.2 & $(6.1)$ & 6.7 \\
\hline Methionine & 13 & $(1.8)$ & 11.6 & $(1.5)$ & 2.0 \\
\hline I soleucine & 28 & $(3.9)$ & 23.6 & $(3.1)$ & 3.6 \\
\hline Leucine & 64 & $(8.8)$ & 60.3 & $(8.0)$ & 6.9 \\
\hline Tyrosine & 15 & $(2.1)$ & 15.1 & $(2.0)$ & 4.0 \\
\hline Phenyla lanine & 36 & $(5.0)$ & 31.3 & $(4.2)$ & 6.1 \\
\hline Tryptophan & 22 & $(3.0)$ & 42.0 & $(5.6)$ & 4.2 \\
\hline Total & 726 & & 754.8 & & \\
\hline
\end{tabular}

a Claiborne and Fridovich, 1979

b schroeder et al., 1982

c aspartic acid and asparagine are both included in this value

d glutamic acid and glutamine are both included in this value 
population in the organism (Ikemura and Ozeki, 1982). In yeast and E. coli, it has also been shown that the level of expression of a gene is reflected in the codon usage (Bennetzen and Hall, 1982; Grosjean and Fiers, 1982).

Grosjean and Fiers (1982) have found that the codon usage in highly expressed E. coli genes is very biased. Codons corresponding to low abundance isoaccepting tRNA's such as AUA for isoleucine, CGG/AGA/AGG/CGA for arginine, CUA for leucine, and GGA (and possibly GGG) for glycine are clearly avoided. In contrast, weakly expressed genes exhibit a random use of codons. Highly expressed E. coli genes also optimize the codonanticodon interaction energies through bias in codon usage. The codons marked by an asterisk in Table 23 are those whose preferential usage is likely to optimize the codon-anticodon interaction energies.

The codon usage of kate is given in Table 23 and it is clear that the usage of codons whose isoaccepting tRNA's are in low abundance is avoided. The preferential usage of most of the other codons was typical of highly expressed genes. Two exceptions to the general trend of high expression codon usage were the preferential use of GCC over GCT for alanine and GAT over GAC for aspartate. Overall the codon bias of katG was typical of a highly expressed gene, It is thought that codon usage may be a way of fine tuning the rate of translation; the preferential use of GCC over GCT for alanine in HPI (HPI having a high alanine content) may be involved in the fine tuning of HPI translation.

\subsubsection{Comparison of HPI to Other Catalase and Peroxidase Proteins}

The predicted amino acid sequence of HPI was compared to the amino acid sequences of BLC (bovine liver catalase)(Schroeder et al, , 1982), 
Table 23. Codon usage in katG

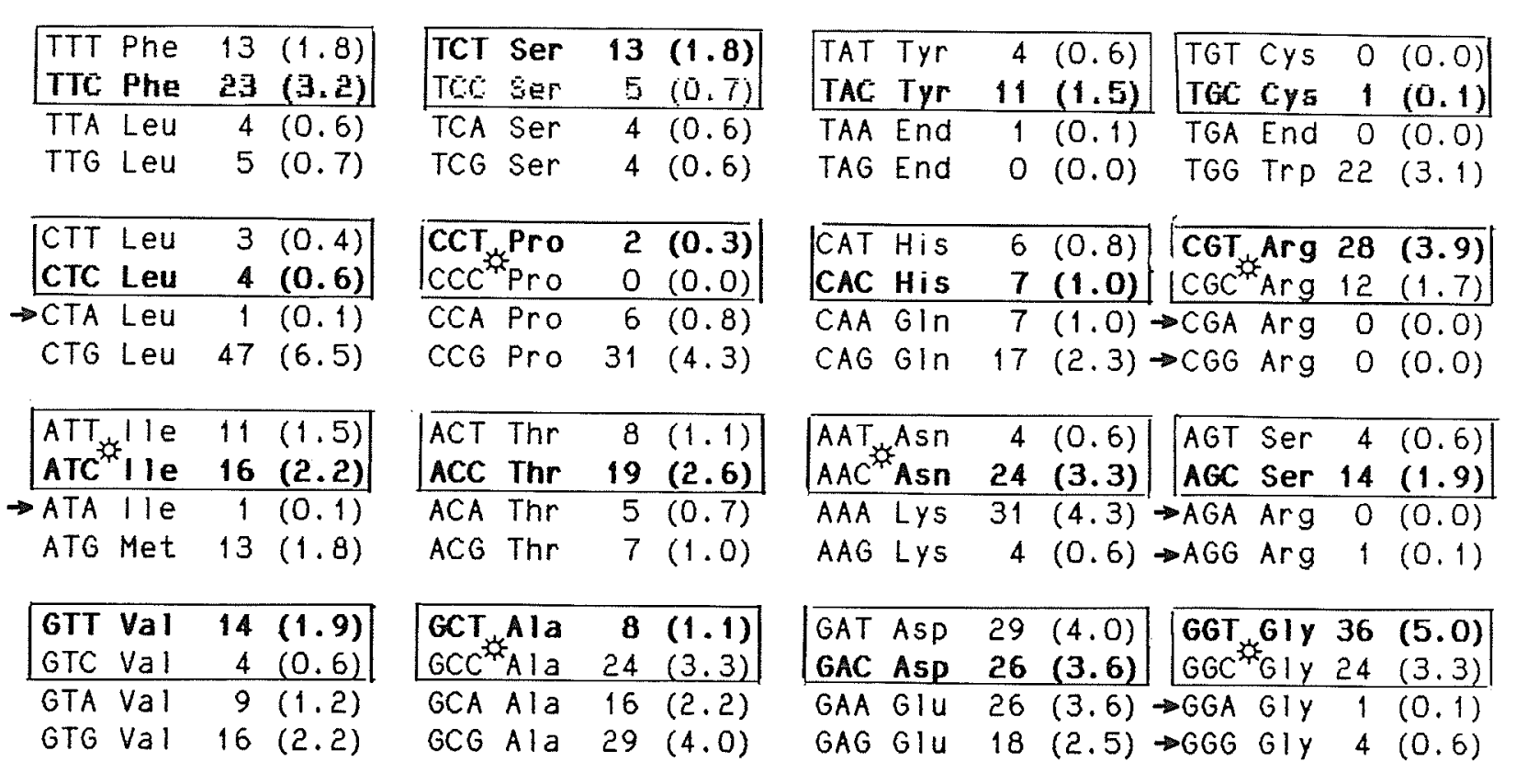

The codon pairs which are in boxes are those which show a bias in usage in highly expressed genes. The boldfaced codons are the ones which are used most frequently in highly expressed genes. Arrows denote codons that are rarely used in highly expressed genes. Asterisks mark codon pairs where the bias in codon usage in highly expressed genes is thought to optimize codon-anticodon interaction energies. The codon usage bias used in this analysis was based on the study of Grosjean and Fiers (1982), where the codon usage of 23 abundantly expressed proteins and 4 proteins of low abundance were compared. 
human catalase (Quan et al., 1986; Bell et al., 1986), yeast catalase T (Hartig and Ruis, 1986), PVC (Penicillium vitale catalase)(Vainshtein et al., 1986), and human myeloperoxidase (Johnson et al., 1987) both manually and by computer. The best possible computer alignments between the HPI protein and the other proteins showed little homology. Homology was manually searched for around residues which were potential ligands for the heme group (ie. His and Tyr). His and Tyr residues were found by $x$-ray crystallography of BLC (Fita and Rossmann, 4985b) and PVC (Vainshtein et al., 1986) to be intimately involved in heme binding and catalysis. Essential residues included the BLC residues predicted to play a role in catalysis, His-74, Ser-113, and Asn-147 as well as several BLC residues thought to interact with the heme group (Pro-335; Arg-353; Tyr-357; Val73; Thr-114; Phe-152). Of the heme binding residues, the region around Tyr-357, the fifth ligand of the heme Fe was the most likely region to be conserved. The regions around Tyr and His (potential ligand replacement) residues were thoroughly searched for homologies, but the homologies were weak and did not extend to any extent into the rest of the protein. All of the catalytic residues and most of the heme binding residues had been conserved in all of the previously sequenced catalases, including yeast catalase T (Hartig and Ruis, 1986) and PVC (Vainshtein et al., 1986), but not in HPI. Consequently, the HPI protein appears to be a novel catalase with no homology to any previously sequenced catalases or peroxidases. The larger size of the HPI catalase was comparable to that of the 670 amino acid PVC which has a flavodoxin-like domain occupying the latter portion of the protein (Vainshtein et al., 1986). The flavodoxinlike domain of the PVC may give it a second function. The larger size of the HPI catalase may also be related to its dual function as both a 
catalase and a peroxidase.

Hydrophilicity plots of the amino acid residues of HPI and BLC are shown in Figure 25. A comparison of the plats showed some common features in the two proteins. In both proteins the largest hydrophobic regions were found approximately 300 residues into the protein. This large hydrophobic region in BLC was part of the $\beta$-barrel domain, extending from residue 56 to 376 . The fifth ligand Tyr-357 of BLC was located just beyond the large hydrophobic region. Tyr-336 of HPI, located near to the end of the hydrophobic region, showed the best (although weak) homology to the Tyr -357 region of BLC. The homology did not extend in

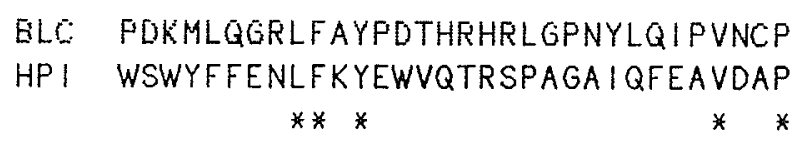

\subsubsection{Cloning and Sequencing of Potential katG Mutant Promoters}

Studies of the katG mutants UM1(katG14), UM2(katG15), and UM56-64 (katG16) implicated the katG mutations in UM2 and UM56-64 as potential regulatory mutants. Although all of these mutants had low levels of catalase, $84 \mathrm{kd}$ proteins could be immunoprecipitated from crude extracts 
Figure 25. Hydrophilicity plots of a) the E.coli HPI catalase and b) bovine liver catalase. Hydrophilic amino acids are represented by positive values while hydrophobic amino acids are represented by negative values. A point has been plotted for each amino acid using the hydrophilicity predictions generated by computer (Microgenie). The computer algorithm on which the prediction was based has been described by Hopp and Woods (1981). 

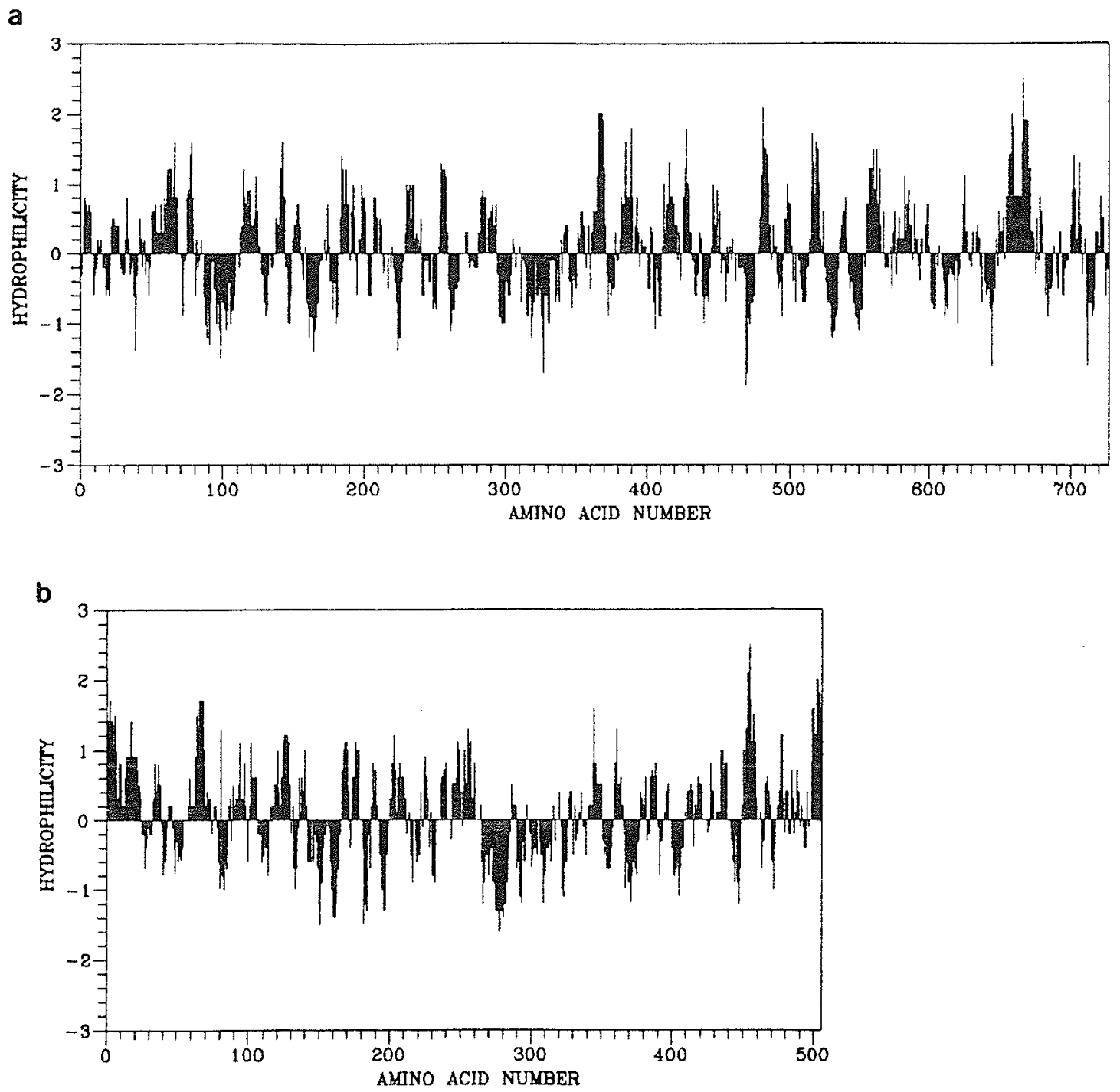
of these mutants with HPI antisera. Each of the mutants displayed a different response to ascorbate induction. UMs, which had peroxidase but not catalase activity, did show an increase in peroxidase activity upon ascorbate induction. UMe had only a small increase in the production of immunoprecipitable protein, lower than would be expected in a normal ascorbate induction. In contrast, UM56-64 showed an abnormally high catalase induction of 25 fold by ascorbate, suggesting that it too had abnormal regulation (Loewen et al., 1985b). These genes were cloned into pAT153 to create the plasmids pMSkatG14, pMSkat615, and pMSkatG16 and characterized (M. Smolenski, 1986).

Bg/ll fragments containing the promoter regions from each of the three mutant katG clones, pMSkat614, pMSkat615, and pMSkat616 were cloned and sequenced. The promoter sequences were identical to the wild type promoter, showing that none of the abnormal regulatory features of these mutant genes were the result of the promoters. A positive regulator of katG, the oxyR protein (Christman et al., 1985) has been shown to interact with the promoter region of kato (Bruce Ames, personal communication) and it is likely that the kat615(UM2), and kat616(UM56-64) strains contain oxyR mutations in addition to katG mutations and are not regulatory mutants.

\subsubsection{Beyond katG}

An 884 bP sequence beyond the apparent termination of the katG mRNA has been included in Figure 26 although the entire region has not been sequenced in both directions. This sequence has been compared by computer to the data base of sequences called GenBank (1986). As no homologous sequences were found, it is likely that this sequence has not been identified and sequenced nor is it similar to any other known genes. This sequence did 
Figure 26. The DNA and predicted amino acid sequences of the region sequenced beyond the termination sequence of katG. The nucleotides are numbered on the right hand side of the page and the amino acids are numbered on the left hand side of the page. The nucleotide sequences recognized by restriction sites mapped in PBT22 are italicized and labelled. 
GATTTCATGAAGCAAGTCACCAGTTACATCGGTGCCTTCGACTTTACCGCCTTACGCTGCATTTTCGGCGCT

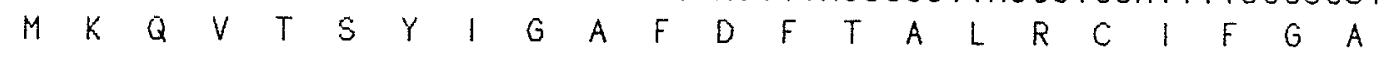

Dral 2639

CTCGTTTTATTCATCGTCCITTTATTACGTGGTCGCGGAATGCGCCCGACACCG ITTAAATACACCTTAGCC

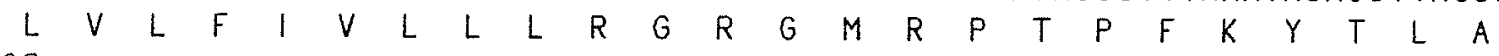
23

2711 ATTGCCCTGTTACAAACCTGCGGGATGGTTGGTCTGGCGCAGTGGGCGTTGGTCAGCGGAGGTGCGGGGAAG 47

$\begin{array}{lllllllllllllllllllllllll}I & A & L & L & Q & T & C & G & M & V & G & L & A & Q & W & A & L & V & S & G & G & A & G & K\end{array}$

2783 GTGGCGATCCTGAGCTATACCATGCCGTTCTGGGTGGTGATTTTCGCCGCGTTGTTTCTCGGTGAACGCCTG $\begin{array}{llllllllllllllllllllllll}V & A & I & L & S & Y & T & M & P & F & W & V & V & \text { I } & F & A & A & L & F & L & G & E & R & L\end{array}$ 71 Sspl Nrul 2855 CGACGTGGGC AATATTTCGCGATTCTGATTGCCGCTTTCCGCTTAATTTTTGGTGTTGCAGCCGTGGCAACT $\begin{array}{rllllllllllllllllllllllll}R & R & G & Q & Y & F & A & \text { I } & L & \text { I } & A & A & F & R & L & 1 & F & G & V & A & A & V & A & T\end{array}$

2927 CGATTTCTCTTCGATGAAAAGTGCCATGCTGGCAATCCTCTCCGGCGTCAGTTGGGGGGCGGCGCGATTCG $\begin{array}{llllllllllllllllllllllll}R & F & L & F & D & E & K & C & H & A & G & N & P & L & R & R & Q & L & G & G & E & R & D & S\end{array}$ 119

2999 ATTGCTAAACGTCTGTTATGCCCGTCATCCGCGCGTGGATTTATTGTC GTTAACATCCTGGCAGATGCTGAC

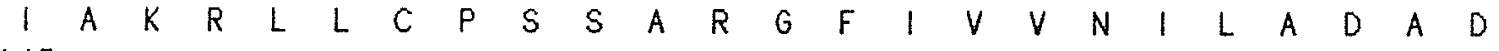
143

GCGGCGCTGGCGATGAGTGTGGTCGCTTTTACTGGTGCCGCAACGTGAAATTGACTGGCAGCCCACCGTGTT

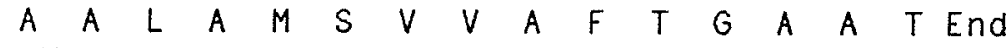
167 CTGGGCGCTTGGCCTACAGTGCGATTATGGCGACAGGCAXXTGGCGTGGAGCTTATGGXGGXGXAXGAAAAA TTAGCCAGCCAGTAATGCCAGTTTAAGCATATTGGCGAAACGTTGCGGAGTGACGGXXXXCXGGXGGCXGCX XGGCGAGAAXXCGAGGGGXCGXXGAAGGGACXGGXXA 
however contain another open reading frame that extended for 181 amino acids and was preceded by a potential shine-Dalgarno sequence, GCA. The termination codon may not be valid because the sequence at this point was deteriorating, and there was only a poor potential terminator, a 5 bp hyphenated dyad. Upstream from the open reading frame were potential promoter sequences, although none had extremely good homology to the consensus sequence. 
DISCUSSION 


\subsection{DISCUSSION}

Three transposon Tn 10 mutations affecting catalase activity in $E$. coli were identified and characterized. Two of the mutants had low catalase levels on agar plates, were ascorbate inducible, and lacked HPII bands on polyacrylamide gels stained for catalase. These characteristics were typical of mutations previously mapped as the loci kate (Loewen, 1984) and katf (Loewen and Triggs, 1984). The mutant loci were mapped by Hfr crosses and P1 transduction as katE12::Tn10 at $37.8 \mathrm{~min}$ and katf13: :Tn10 at $59 \mathrm{~min}$ on the E. coli chromosome. The third mutation, kat 17::Tn 10, was selected for its low catalase activity in a strain that already lacked HPII (KatE). Kat17::Tn 10 was no longer ascorbate inducible, and it lacked the bifunctional HPI-A and HPI-B bands on polyacrylamide gels stained for catalase or peroxidase. This mutation was identified by $P 1$ transduction to be kat617::Tn 10 and mapped to 89.2 min on the E. cali chromosome between the markers argH and metB.

The three catalase loci, katE, katf, and katG are widely separated on the E. cali chromosome and obviously do not form an operon. Loewen et al. (1985b) suggested that the katG and katE genes which are separated by about 50 min on the E. coli chromosome map may have resulted from a duplication of the E. coli chromosome early in evolution. It is believed that two entire duplications of the $E$. coli chromosome may have placed related loci 25 or 50 minutes away from each other. Indeed other duplicated genes, such as $p f k A$ and $\rho f k B$ are clustered 25 or $50 \mathrm{~min}$ away from each other on the E. coli chromosome (Riley and Anilionis, 1978). Recently, katf has been identified as a regulatory protein required for the production of HPII catalase (M. Mulvey, unpublished 
results), suggesting that katE is the structural gene for HPII catalase. If this is the case, then the theory that the two catalase genes, katE and katG may have evolved from one ancestral gene is plausible. However, under stringent hybridization conditions, katG did not hybridize with any other E. coli genes, showing that the relationship between HPI and HPII may be so distant that any homology may be evident only after comparison of the protein sequences of these two catalases.

No other loci affecting catalase activity in E. coli were identified in our lab, although katA-D have been identified in $s$. typhimurium by Levine (1977). Of these loci, only one, katc, was mapped by $P 1$ transduction to $7 \mathrm{~min}$, and at present no equivalent locus has been identified in E. coli.

HPI (KatG protein) has recently been identified as a part of an oxidative regulon controlled by the positive regulatory protein, $0 x y R$ (Christman et al., 1985). This regulon can be induced by a number of oxidative chemicals, including $\mathrm{H}_{2} \mathrm{O}_{2}$, accounting for the ascorbate induction of the transposon mutants which still contained HPI catalase. The katE and katf loci affecting HPII catalase in E. coli are regulated independently. HPII is not ascorbate inducible, nor is it under the control of the positive regulator OxyR. Normally, HPI is constitutively produced during $\log$ phase growth, but it is inducible by $\mathrm{H}_{2} \mathrm{O}_{2}$ to higher levels (Loewen et al., 1985a). Morgan et al. (1986) have shown that the induction of the HPI protein occurs at the level of transcription, with oxyR1 mutants (mutants where OxyR protein is overproduced) having approximately 50 fold more katG mRNA and 50 fold more catalase than normal. As discussed in the historical, glucose also affects the katG mRNA levels, but the mechanism of action remains obscure since the 
available evidence suggests that it is not via classical catabolite repression. This information indicates that katG is under both positive and negative control and is inducible to levels at least 50 fold higher than normal non-induced catalase levels.

The oxyR locus has been mapped to $88 \mathrm{~min}$ in $S$. typhimurium, near to the katG gene. A deletion in S. typhimurium extending from metB to argH eliminated the HPI-A and HPI-B proteins but left the oxyR protein (Christman et al., 1985), showing that these genes do not form an operon. However, the mapping of the $E$. coli oxyR gene in our lab (unpublished results) suggested that oxyR was closer to katG than either metB or argH. Another difference in the oxyR regulion of $E$. coli and $S$. typhimurium has already been identified, that is the requirement of both oxyR and $h t p R$ for the induction of the novel alkylhydroperoxidase (ahp) by heat shock in $S$. typhimurium but not in E. coli (Morgan et al., 1986). Consequently, the placement of oxyR in a position closer to katG on the $E$. coli chromosome can not be eliminated.

The tetracycline resistance conferred by the Tn 10 mutations in the three catalase genes simplified the construction of strains carrying specific catalase mutations because it provided a positive selection system for the catalase mutation. The transfer of these mutations into various strains allowed the study of the independent induction of the HPI and HPII catalases (Loewen et al., 1985a) as well as the construction of other catalase mutants for specific purposes, including the cloning of katG, katE, and katf. The construction of mutants lacking catalase, but of known genotype, was necessary to be certain that the catalase gene of interest would complement the mutation in the strain if it was cloned. Besides the certainty of the catalase genotype, the transposon mutants 
had other advantages over the traditionally isolated nitrosoguanidine mutants. The low frequency of insertion of transposon Tn10, approximately $10^{-5}$ to $10^{-6}$ transpositions per input phage genome (Foster et al., 1984), allowed the isolation of single mutations with otherwise unaltered genetic backgrounds. In contrast, NG mutants often have multiple mutations, so the genetic make up of the strain was always uncertain. The insertion of the transposon in the case of katG prevented the production of any immunoprecipitable HPI protein (Loewen et al., 1985b), allowing experiments without HPI or the inactive protein to be per formed.

The plasmid pLC36-19 was selected from the clarke and Carbon plasmid bank (1976) because it conferred a higher level of catalase on its host. pLC36-19 complemented the catalase deficiencies of catalase mutants, and it contained the structural gene(s) for the HPI-A and HPI-B isoenzyme pair (Loewen et al., 1983). However, because only $2.5 \mathrm{~kb}$ of the $19.2 \mathrm{~Kb} E$. coli genomic DNA insert in DLC36-19 was needed to code for the 84000 dalton HPI protein, it was necessary to identify the location of the catalase gene and subclone it for a more detailed characterization. In order to localize the portion of pLC36-19 required for the synthesis of the HPI protein, fourteen restriction enzymes were mapped in pLC36-19 and transposon Tn5 insertions were made in the plasmid. Although Tn5 insertions have successfully been used for the correlation of plasmid function and location in other instances (DeBruijn and Lupski, 1984), only four Tn5 insertions mapping at different locations in the plasmid were isolated, and none of these disrupted the catalase activity conferred by the plasmid. These insertions did indicate where the HPI gene was not located and making use of this information and the new 
restriction sites provided by the transposon, Hindlll deletion mutants of the transposon carrying plasmid, DC1, were isolated. Two plasmids, PBT1 and PBT2 were isolated and Hindlll restriction digests of the plasmids were found to differ by only one restriction fragment. PBT2 which contained a $3.8 \mathrm{~kb}$ Hindll fragment not present in PBT 4 was also capable of complementing the catalase deficiency of a mutant, UM53, while PBTI was not. The orientation of the $3.8 \mathrm{~kb}$ Hindlll fragment in the deletion plasmid was confirmed to be the same as in pLC36-19. These results localized the coding region in part or in total to the $3.8 \mathrm{~kb}$ Hindlll fragment of pLC36-19.

The next obvious step was to subclone the $3.8 \mathrm{~kb}$ Hindlll fragment into the higher copy number vector, PAT153. This gave the catalase encoding plasmid DBT22, and the same insert in the opposite or ientation gave the catalase encoding plasmid, PBT54. Both plasmids conferred high catalase levels to the catalase deficient mutant, UM53, which confirmed that the entire gene was contained on the $3.8 \mathrm{~kb}$ Hindlll fragment and that catalase expression was not being influenced by the promoter of the plasmid tetracycline resistance gene. Sites for 14 restriction enzymes were mapped in PBT22 to provide markers for further analysis. The same enzyme sites are presumed to be present in DBT54, but in the opposite or ientation.

The boundaries of the catalase gene were further defined by deletion analysis. The $0 \mathrm{~kb}$ end of the Hindlll insert in pBT22 was defined by a specific deletion of a 340 bp ECORI fragment. The deletion of this fragment disrupted catalase activity, a result which places one of the ends of the HPI gene within $300 \mathrm{bp}$ of the $0 \mathrm{~kb}$ end of the insert. The initial attempt to define the opposite end of the gene was made using 
pBT5, a clone of the 7550 bp Sphl fragment from pLC36-19 which contained most of the Hindlll $3.8 \mathrm{~kb}$ fragment and extended beyond the $0 \mathrm{~kb}$ end into PLC36-19. Because PBT5 did not have catalase activity, the opposite end of the gene must lie beyond the Sphl site. BAL31 deletions were used to further define the $3.8 \mathrm{~kb}$ end of the gene. A BAL31 mutant which retained catalase activity, DBT28, had a deletion which extended through the Hincll site at the $3.8 \mathrm{~kb}$ end of the insert but stopped before the Nrul site at $2.8 \mathrm{~kb}$. The deletions in two catalase deficient BAL31 mutants, DBT29 and PBT30, extended slightly beyond the Nrul site at the $3.8 \mathrm{~kb}$ end of the insert, but ended before the Sphl site. This result confined the HPI gene to a region of approximately $2.5 \mathrm{~kb}$ extending from within $300 \mathrm{bp}$ of the 0 $\mathrm{kb}$ end to a point between the $\mathrm{Nr} \mathrm{Cl}$ and Sphl sites at 2.0 and $2.8 \mathrm{~kb}$ respectively. The small deletions of DBT29 and DBT30 which destroyed the catalase activity suggested that the end of the gene was closer to the Nrul than the Sphl site. This was later confirmed by the DNA sequence. The isolated deletion mutants were used to define the HPI promoter region. Crude protein was first isolated from catalase deficient strains bearing the mutant plasmids PBT24 and PBT5 with the hope that a deletion in the promoter end would prevent the production of immunoprecipitable protein, while a deletion at the c-terminal end would permit the production of immunoprecipitable protein. However, neither mutant plasmid produced any immunoprecipitable protein, suggesting that the absence of the carboxyl terminus of the protein either prevented it from being recognized by the antisera or made it so unstable that it was degraded before it could be isolated. The next approach was to use maxicell analysis to examine the plasmid encoded polypeptides of the isolated deletion plasmids. The identification of HPI proteins synthesized from DBT29 and 
DBT30 which were less stable, but nearly as large as the HPI proteins produced from DBT22, DBT54, and DBT28, suggested that they had small deletions at the $3.8 \mathrm{~kb}$ end and that this was in the c-terminal end of the gene. A deletion at the opposite end, as in DBT24, produced a 45000 dalton protein, much smaller than would be expected if the deletion were in the C-terminus of the protein. Therefore the promoter appeared to be situated at the $0 \mathrm{kD}$ end of the $3.8 \mathrm{~kb}$ Hindll fragment. This conclusion was confirmed by cloning a $320 \mathrm{bp} B g / l l$ fragment from the $0 \mathrm{~kb}$ end into the promoter cloning vector pKK232-8. This fragment directed the transcription of a promoterless chloramphenicol acetyltransferase gene, showing that the promoter was at the $0 \mathrm{~kb}$ end. A potential promoter region has since been identified in this same fragment by sequencing (see below), and the positive regulator of the gene, oxyR, has also been confirmed to interact with this Bglll fragment (Gisela storz, personal cormunication).

Although the gene on PBT22 was known to encode the structural gene for HPI catalase and the katG gene that had been previously mapped at $89.2 \mathrm{~min}$ on the E. coli chromosome was suspected to be the structural gene, there was no proof that katG was the structural gene. By hybridizing 32p-labelled PBT22 to genomic digests of wild type $E$. coli DNA and $E$. coli DNA containing a Tnto insertion in katG, the structural gene on PBT22 was confirmed to be the same gene in which a Tn 10 had been inserted and mapped as katG. This was evident from the change in hybridization pattern observed between Hincll digests of $E$. coli genomic DNA with and without a Tn1O insertion in katG.

After characterizing the HPI gene and identifying it as katG, fragments were subcloned into $M 13$ mp18 and M13mp19, and the entire gene 
was sequenced using dideoxy chain termination sequencing. An open reading frame of 2178 bp coding for a 726 amino acid polypeptide was identified in the sequence. This sequence also had appropriately placed Shine-Dalgarno, -10 and -35 sequences upstream to it which showed relatively good homology to the E. coli consensus sequence. The -35 sequence exhibited the poorest consensus to the $E$. coli sequence, possibly reflecting the fact that katg is a positively regulated gene, as positively regulated genes usually have poor homology to the $E$. coli-35 consensus sequence (Harley and Reynolds, 1987).

It is known that OxyR protein binds in the promoter region of katG (Gisela Storz, personal communication), so there may be a consensus sequence like that found in the heat shock genes and alkylation response genes which allows the recognition by the positive regulators HtPR and Ada (Gottesman, 1984; Teo et al., 1986). No homology to the heat shock promoter consensus sequence (Watson et al., 1987) or the ada promoter consensus sequence (Teo et al., 1986) was identified in katG, supporting the findings of Christman et al. (1985) that the HPI-A and HPI-B proteins are not part of the oxidative regulon that was also induced by other stresses such as heat shock. However, a region covering the -10 sequence of the promoter was identified that showed marked homology to the lexA binding region consensus sequence (Watson et al., 1987).

taCTGTatata-a-aCAGta lexA binding consensus sequence

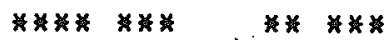
CGCTGTGTATCGTAACGGTA katG sequence starting at base 102

The capital letters represent bases in the lexA consensus sequence that are highly conserved while the bases represented by small letters are weakly conserved. Although there is no evidence that katG is repressed by LexA protein (a negative regulator of the sos response), this homology 
may indicate that a relationship with the oxidative response should be investigated further. The promoter region of katG and its interaction with the positive regulator $0 x y R$ is presently being investigated by Gisela storz.

A potential termination sequence was also located in an appropriate location downstream from the termination codon. The most commonly used termination codon, UAA (Watson et al., 1987), was found 8 bp upstream from a $14 \mathrm{bp}$ hyphenated dyad. The hyphenated dyad is capable of base pairing to form a long stem and loop structure with a single base mismatch. This loop is extremely stable with a $\Delta G=-21.4 \mathrm{Kcal}$. This stem and loop structure in combination with the following 5 uracil residues should allow rho independent termination to occur, although the polyU region is shorter than that normally present in rho independent terminators. This may be compensated for by the high stability of the stem and loop structure.

As a single base inclusion or exclusion in a DNA sequence shifts the inferred protein sequence out of frame, it is necessary to confirm that the predicted sequence is correct by sequencing a portion of the protein. Unfortunately, the N-terminus of the HPI protein was blocked and could not be sequenced, like that of the bovine liver catalase. Schroeder et al. (1964) originally suggested that the N-terminus of bovine liver catalase may be blocked by an acetyl group, but this was not confirmed by $x$-ray crystallography or positive and negative ion mass spectroscopy (Schroeder et al., 4982a). In bacteria, N-a-acetylated proteins are rare, and at present the only known acetlyated proteins are the E. coli ribosomal proteins, L12, S5, S18, tu, and L7 (Tsuansawa and Sakiyama, 1984). Other groups cormonly modifying the $\mathrm{N}$-terminus of 
proteins include formyl and pyroglutamyl groups (Price and stevens, 1982).

The HPI protein must be modified in some manner because two "isoenzyme" forms are produced by the katG gene. This may be the result of some type of $\mathrm{N}$-terminal modification that results in a charge variant. Moss (1982) said that secondary isoenzymes (isoenzymes that are not encoded by separate genes), may result from the covalent modification of the protein or by the covalent attachment of small molecules or radicals that could alter their properties. It is possible that the covalent attachment of cellular $\mathrm{H}_{2} \mathrm{O}_{2}$ to the HPI active site results in one of the secondary isoenzyme forms. There is no evidence that the two forms of $H P I, H P I-A$ and $H P I-B$, result from the cleavage of a signal peptide from a preHPI protein. There appeared to be no signal peptide in the HPI predicted amino acid sequence, and the same sample that produced two bands on a native polyacrylamide gel produced only one protein band on an SDS-PAGE gel. Furthermore, studies in our lab (unpublished results), showed that HPI was neither a secreted nor a membrane-contained protein, although Kranz et al. (1984) have suggested that HPI may be a minor membrane protein. Kranz suggests that $h$ is findings mabe the result of a small amount of cytoplasmic protein contamination in the membrane preparation.

Since the N-terminus was blocked, cyanogen bromide was used to produce peptides for sequencing. Because cyanogen bromide cleaves at methionine residues, sequences succeeding methionine residues were searched for in the sequenced cyanogen bromide peptides. Claiborne and Fridovich (1979) examined the peptides produced by cyanogen bromide cleavage of HPI and found the protein contained 13 to 14 methionine 
residues. The HPI predicted sequence contained 13 methionine residues, and seven of the sequenced cyanogen bromide cleaved peptides were identified in the HPI sequence. Although there were some discrepencies between the HPI predicted sequence and the determined amino acid sequence, the presence of all the peptides in the predicted sequence and the continued matching of amino acid residues even after a contradictory residue showed that the protein was in the correct reading frame.

The HPI predicted amino acid sequence gave a molecular weight of 80049 daltons, similar to the apparent SDS/PAGE molecular weights for HPI of 78000 (Claiborne and Fridovich, 1979) and 84000 and the gel filtration molecular weight of 81000 (Loewen and Switala, 1986). This reconfirmed that the protein was HPI and that the protein reading frame was correct. The amino acid composition compared favourably with that determined by claiborne and Fridovich (1979). There was disparity in the amino acid contents of the predicted sequence and the analyzed amino acid contents in the serine, threonine, and tryptophan residues. This was not unexpected since serine, threonine, and tryptophan contents were analyzed independently from the other amino acids. The most unusual feature about the amino acid composition of HPI was the presence of only one cysteine residue in such a large protein. The lack of cysteine was substantiated by the chemically determined amino acid compositions. These results show that disulfide linkages are not important in the stabilization of the HPI protein. The similarity between the amino acid compositions of BLC and HPI was surprising considering that there is no homology between these two proteins. The amino acid content could however reflect the fact that both are cytoplasmic proteins with a similar function. 
At this point the HPI amino acid sequence was compared to a number of other catalases whose protein sequences have been determined or predicted. These included BLC (Schroeder et al., 1982), human catalase (Quan et al., 1986; Bell et al., 1986), yeast T-catalase (Hartig and Ruis, 1986), and PVC (Penicillium vitale catalase; Vainshtein et al., 1986). Since the PVC amino acid sequence was predicted only on the basis of the $x$-ray structure, most of the attention was directed to the alignment of HPI with bovine liver and yeast-T catalase. All of the previously characterized catalases show considerable homology; human and bovine liver catalases are very similar and yeast-T catalase and PVC showed good homology in the B-barrel or heme binding domain, although not in the NAD(P)H binding domain. Both yeast T-catalase and PVC are larger than bovine liver or human catalases by 36 aa and 144 aa respectively. The extension of the PVC has the structure of a flavodoxin binding domain. HPI is also considerably bigger (200 aa) than BLC but no function has been assigned to the extra amino acids. The dual function of HPI may require more amino acids to form a second functional domain.

The HPI protein showed no homology to the previously sequenced catalases. The only potential homology was identified around Tyr-336 Which had homology with four of the amino acids surrounding the Tyr-357 of BLC which acts as the fifth ligand of the Fe of the heme group. However, the homology did not extend in either direction around this region, suggesting that if Tyr-336 is a ligand of $F e$, none of the other features of the heme binding domain have been conserved.

HPI's lack of homology with other catalases identifies it as a unique catalase with many properties that differ from previously characterized catalases. As described in the historical, the HPI enzyme 
is not only a catalase but a broad spectrum peroxidase, capable of using much larger substrates than typical catalases in the peroxidatic mode. This would demand a much different active site from that which has been determined to be present in BLC and PVC by x-ray crystallography. Chance (1949) found that the rate of oxidation of compounds by BLC was reduced by an order of magnitude for each additional carbon atom in the $R$ group of straight chain alcohols, probably because of the limited diameter of the channel accessing the heme. The deep channel accessing the active site is so narrow that entrance is limited to molecules with a van der Waal's diameter of less than $3.5 \mathrm{~A}$ (Fita and Rossmann, 1985b), preventing large substrates from reaching the active site. HPI would need a wider channel or a separate active site to allow access to the large substrate molecules used in the peroxidatic mode. The HPI active centre may be more like that of cytochrome-c-peroxidase where the heme environment is polar and partially accessible to solvent. Cytochrome-c-peroxidase also has different essential active site residues and instead of the heme itself forming a radical during the reaction, this function is performed by an amino acid side chain (Fita and Rossmann, 1985b).

Unlike typical catalases, HPI was resistant to inhibition by AT, a compound that interacts with His-74 of the active site of BLC Margoliash et al., 1960) and inhibits it. This also supports the concept that HPI is a unique catalase.

Another characteristic exemplifying the difference between the active sites of HPI and other characterized catalases was the broad pH maxima exhibited by typical catalases while HPI catalase has a narrow $\mathrm{pH}$ optimum at $\mathrm{pH} 6.8$. Murthy et a1. (1981) have suggested that the broad $\mathrm{pH}$ optimum of BLC may be a result of the unoccupied sixth ligand of the 
Fe. Other heme proteins which do not exhibit $\mathrm{pH}$ independence, such as metmyoglobin and cytochrome-c-peroxidase, have water occupying the sixth ligand of $\mathrm{Fe}$. The narrow DH optimum of HPI catalase may indicate that the sixth ligand of $\mathrm{Fe}$ in this protein is occupied by water or another amino acid side chain.

The codon usage of kato was generally like that of a highly expressed gene. Exceptions to this included the alanine and aspartate codons, where the codon bias was not typical of highly expressed genes. As previously suggested, the choice of the less optimal codons in kat6 for alanine may be a method of translational control for the fine tuning of katg expression as katg has a high alanine content. Codons with low abundance isoaccepting tRNA's were clearly avoided. Alternatively, katG could be considered just a moderately expressed gene; the codon usage in the yeast $T$-catalase was typical of a moderately expressed gene (Hartig and Ruis, 1986). It was expected that the katG gene would exhibit some codon bias to allow the efficient translation observed when katG is induced to higher levels.

Three promoters of mutant catalase genes, katG14 (UM1), katG15 (UM2), and katG16 (UM56-64) were cloned and sequenced. Two of these mutants, katG15 and katG16 had been partially characterized (Loewen et al., 1985b; Mark Smolenski, 1986) and were suspected promoter mutants. However, the sequences of all the promoters were identical to the wild type sequence, showing that these mutants were not kato regulatory mutants. The altered regulatory characteristics may have resulted from mutations in the positive regulator of katG, oxyr. The multiple mutations typical of nitrosoguanidine mutants may explain the various phenotypes exhibited by the katG15 and kat616 mutants, all having lower 
catalase activity and abnormal regulation of this activity.

The relevance of the 884 bp sequence beyond the termination sequence of katG is at present unknown. It does not contain the oxyR sequence or any other sequences presently recorded in Genbank (1986), although there is a potential open reading frame. This region could contain some other oxygen regulated loci, as studies by Alibadi et al., (1986), have revealed six oxygen inducible operon fusions, two of these, oxiC and oxiE, which map close to oxyR in S. typhimurium.

The katG gene product HPI was physically characterized and revealed as a unique catalase, unlike any other previously sequenced catalases. This conclusion was supported by the chemical properties differentiating HPI from typical catalases. In contrast to eucaryotic catalases, bacterial catalases appear to be a very diverse family of enzymes which have evolved to deal with their particular niches. The detailed characterization of HPI supported the concept that bacterial enzymes are very diverse. This has been further corroborated by the inability of katG to hybridize to genomic DNA from either Acinetobacter anitratum or Pseudomonas aeruginosa under non-stringent hybridization conditions (Pam Sorbey, unpublished results). Another example of an E. coligene which is not highly conserved is the $P p C$ gene which did not hybridize with DNA from certain other bacteria (Sabe, 1984), further demonstrating the diversity of bacterial evolution. It may be that similar catalases will only be found among the very closely related Enterobacteriaceae, as even Proteus mirabilis, a member of the Enterobacteriaceae family does not have a similar catalase with a broad spectrum peroxidase activity (Jouve et al., 1984).

Once the sequence of the HPII catalase has been predicted from the 
DNA sequence, the conserved regions of the HPI protein may be identified by alignment. In yeast, al though the catalases $A$ and $T$ do not hybridize to each other (Cohen et al., 1985), they both show homology to BLC. If this is the case in E. Coli, the sequence of HPII may lead to the identification of the conserved regions of HPI which are important for heme binding and catalysis.

Now that the HP! protein has been pur ified and sequenced, the next step in understanding the significance of the protein to $E$, coli will be to identify the residues playing important roles in the structure and function of the enzyme. This may be done by determining residues which appear to be important to the active site by x-ray crystallography or by comparison to other similar catalase proteins. Attempts are now being made to crystallize the HPI catalase for x-ray crystallography. The regulation of HPI is also an interesting field of investigation and an understanding of the regulation of katg could lead to a better understanding of its function. The fact that high levels of HPI can efficiently lower the rates of spontaneous mutation in salmonella typhimurium (sies et al., in press) suggests that catalase has a much more important role in the cell than had previously been presumed. Further investigation of this unique E. coli catalase, hydroperoxidase 1 , is necessary to provide a better understanding of how organisms cope with toxic oxygen species. 
REFERENCES 


\subsection{REFERENCES}

Aliabadi, Z., F. Warren, S. Mya, and J. W. Foster. 1986. Oxygen-regulated stimulons of Salmonella typhimurium identified by Mud (AD IaC) operon fusions. J. Bacteriol. 165:780-786.

Allgood, G. S. and J. J. Perry. 1986. Characterization of a manganesecontaining catalase from the obligate thermophile Thermoleophilum album. J. Bacteriol. 168:563-567.

Ananthaswamy, H. N. and A. Eisenstark. 1977. Repair of hydrogen peroxide-induced single-strand breaks in Escherichia coli deoxyribonucleic acid. J. Bacteriol. 130:187-191.

Armel, P. R., G. F. Strniste, and S. S. Wallace. 1977. Studies on Escherichia coli x-ray endonuclease specificity. Roles of hydroxyl and reducing radicals in the production of DNA lesions. Radiat. Res. 69:328-338.

Atassi, M. Z., and A. F. S. A. Habeeb. 1972. Reactions of proteins with citraconic anhydride. Methods Enzymol. 25:546-553.

Bachmann, B. J. 1983. Linkage Map of Escherichia coli K-12, edition 7. Microbiol. Rev, 47:180-230.

Barbado, C., M. Ramirez, M. Angel-Blanco, J. Lopez-Barea, and C. Pueyo. 1983. Mutants of Escherichia coli sensitive to hydrogen peroxide. Curr. Microbiol. 8:251-253.

Barnes, W. M. 1977. Plasmid detection and sizing in single colony lysates. Science 195:393-394.

Beauchamp, C., and I. Fridovich. 1970. A mechanism for the production of ethylene from methional. J. Biol. Chem. 245:4641-4646.

Bell, G. I., R. C. Najarian, G. T. Mullenbach, and R. A. Hallewell. 1986. CDNA sequence coding for human kidney catalase. Nucl. Acids Res. 14:5561-5562.

Bennetzen, J. L., and B. D. Hall. 1982. Codon selection in yeast. J. Biol. Chem. 257:3026-3031.

Bilinski, T., Z. Krawiec, A. Liczmanski, and J. Litwinska. 1985. Is hydroxyl radical generated by the fenton reaction in vivo? Biochem. Biophys. Res. Commum. 130:533-539.

Birnboim, H. C. 1983. A rapid alkaline extraction method for the isolation of plasmid DNA. Methods Enzymol. 100:243-255.

Birnboim, H. C., and J. Doly. 1979. A rapid alkaline extraction procedure for screening recombinant plasmid DNA. Nucl. Acids Res. $7: 1513-1523$. 
Bochner, B. R., P. C. Lee, S. W. Wilson, C. W. Cutler, and B. N. Ames. 1984. AppDPA and related adenylylated nucleotides are synthesized as a consequence of oxidation stress. Cell 37: 225-232.

Bolivar, F., R. L. Rodriguez, P. J. Greene, M. C. Betlach, H. L. Heyneker, and H. W. Boyer. 1977. Construction and characterization of new cloning vehicles 11. A multipurpose cloning system. Gene 2:95-113.

Borer, P. N., B. Dengler, I. Tinoco Jr., and O. C. Unlenbeck. 1974. Stability of $r$ ibonucleic acid double-stranded helices. J. Mol. Biol. 86:843-853.

Boulnois, G. J. and K. N. Timmis. 1984. Synthesis of plasmid encoded polypeptides in maxicells. In Advanced Molecular Genetics. (A. Puhler and K. N. Timmis, eds.) Springer-Verlag, Berlin, Germany. PD. 204-211.

Boyer, H.W. and D. Roulland-Dussoix. 1969. A complementation analysis of the restriction and modification of DNA in Escherichia coli. J. Mol. Biol. 41:459-472.

Breimer, L. H. and T. Lindahl. 1985. Enzymatic excision of DNA bases damaged by exposure to ionizing radiation or oxidizing agents. Mutat. Res. 150:85-89.

Brosius, J. 1984. Plasmid vectors for the selection of promoters. Gene 27:151-160.

Carlsson, J. and W. S. Carpenter. 1980. The recAt gene product is more important than catalase and superoxide dismutase in protecting Escherichia coli against hydrogen peroxide toxicity.

J. Bacteriol. 142:319-321.

Chance, B. 1949. The primary and secondary compounds of catalase and methyl or ethyl hydrogen peroxide. J. Biol. Chem. 179:13411369.

Christman, M. F., R. W. Morgan, F. S. Jacobson, and B. N. Ames. 1985. Positive control of a regulon for defenses against oxidative stress and some heat-shock proteins in salmonella typhimurium. cell $41: 753-762$.

Claiborne, A, and 1. Fridovich. 1979. Purification of the o-dianisidine peroxidase from Escherichia coli B. J. Biol. Chem. 254:42454252 .

Claiborne, A., D. P. Malinowski, and I. Fridovich. 1979. Purification and characterization of hydroperoxidase 11 of Escherichia coli B. J. Biol. Chem. 254:11664-11668.

Claiborne, A. 1978. Relationship between catalase and dianisidine peroxidase in Escherichia coli B. Fed. Proc. 37:1513. 
Clarke, L. and J. Carbon. 1976. A colony bank containing synthetic coles hybrid plasmids representative of the entire $E$. coli genome. Cell 9:91-99.

Clayton, R. K. 1959. Pur ified catalase from Rhodopseudomonas spheroides. Biochim. Biophys. Acta 36:40-47.

Clewell, D. B. 1972. Nature of Colel plasmid replication in Escherichia coli in the presence of chloramphenicol. J. Bacteriol. 110:667-676.

Cohen, G., F. Fessl, A. Traczyk, J. Rytka, and H. Ruis. 1985. Isolation of the catalase A gene of Saccharomyces cerevisiae by complementation of the ctal mutation. Mol. Gen. Genet. 200:74-79.

Dabbs, E. R. 1981. The gene for ribosomal protein L31, rpmE is located at 88.5 minutes on the Escherichia coli chromosomal I inkage map. J. Bacteriol. 148:379-382.

Davis, B. J. 1964. Disc electrophoresis. 11. Method and application to human serum proteins. Ann. N. Y. Acad. Sci. 121:404-427.

De Bruijn, F. J., and J. R. Lupski. 1984. The use of transposon Tn5 mutagenesis in the rapid generation of correlated physical and genetic maps of DNA segments cloned into multicopy plasmids -a review. Gene 27:131-149.

Demple, B. and J. Halbrook. 1983. Inducible repair of oxidative damage in Escherichia coli. Nature 304:466-468.

Demple, B., J. Halbrook, and S. Linn. 1983. Esherichia coli $x$ th mutants are hypersensitive to hydrogen peroxide. J. Bacteriol. 153: 1079-1082.

Dickerson, R. E., H. B. Gray, and G. B. Haight. 1979. Chemical Principles. The Benjamin/Cumings Publishing Company Inc., Don Mills, Ontario.

Dingman, D. W. and D. P. Stahly. 1984. Protection of Bacillus larvae from oxygen toxicity with emphasis on the role of catalase. Appl. Environ. Micro. 47:1228-1237.

Eisenstark, A. and G. Perrot. 1987. Catalase has only a minor role in protection against near-ultraviolet radiation damage in bacteria. Mol. Gen. Genet. 207:68-72.

Farr, S., R. D'Ari, and D. Touati. 1986. Proc. Nat1. Acad. Sci. USA, in press.

Farr, S. B., D. O. Natvig, and T. Kogoma. 1985. Toxicity and mutagenicity of plumbagin and the induction of a possible new DNA repair pathway in Escherichia coli. J. Bacteriol. 164: 1309-1316. 
Fee, J.A. 1982. Is superoxide important in oxygen poisoning? Trends Biochem. Sci. 7:84-86.

Fields, P. I., R. V. Swanson, C. G. Haidaris, and F. Heffron. 1986. Mutants of Salmonella typhimurium that cannot survive within the macrophage are avirulent. Proc. Natl. Acad. Sci. USA $83: 5189-5193$.

Finn, G. J. and S. Condon. 1975. Regulation of catalase synthesis in salmonella typhimurium. J. Bacteriol. 123:570-579.

Fita, 1. and M. G. Rossmann. 1985a. The NADPH binding site on beef liver catalase. Proc. Nat1. Acad. Sci. USA 82:1604-1608.

Fita, 1. and M. G. Rossmann. 1985b. The active center of catalase. J. Mol. Biol. 185:21-37.

Foster, T. J., V. Lundblad, S. Hanley-Way, S. M. Halling, and N. Kleckner. 1981. Three Tn10-associated excision events: relationship to transposition and role of direct and inverted repeats. Cell 23:215-227.

Frey, J., M. Bagdasarian, and K. N. Timmis. 1984. Generation of deletion mutations in vitro with the BAL31 exonuclease. In Advanced Molecular Genetics. (A.Puhler, and K. N. Tirmis eds.) Springer-Verlag, Berlin, Germany. pp. 141-150.

Fridovich, 1, 4986. Biological effects of the superoxide radical. Arch. Biochem. Biophys, 247:1-11.

Fridovich, 1. 1978. The biology of oxygen radicals. Science 201:875880.

Fridovich, 1. 1977. Oxygen is toxic! Bioscience 27:462-466.

Friesen, J. D., J. Parker, R. J. Watson, N. P. Fiil, S. Pedersen, and F.S. Pedersen. 1976. Isolation of lambda transducing bacteriophage carrying the relA gene of Escherichia coli. J. Bacteriol. 127:917-922.

Furuta, S., H. Hayashi, M. Hijikata, S. Miyazawa, T. Osumi, and T. Hashimoto. 1986. Complete nucleotide sequence of CDNA and deduced amino acid sequence of rat liver catalase. Proc. Nat1. Acad Sci. 83:313-317.

Ganoza, M. C., E. C. Kofoid, P. Marliere, and B. G. Louis. 1987. Potential secondary structure at translation-initiation sites. Nucl. Acids Res. 15:345-359.

Glover, D. M. 1984. Gene Cloning. Chapman and Hall, N.Y., N.Y.

Goff, S. A., and A. L. Goldberg. 1985. Production of abnormal proteins in E. coli stimulates transcription of lon and other heat 
shock genes. Cell 41:587-595.

Gregory, E. M., and I. Fridovich. 1974. Visualization of catalase on acrylamide gels. Anal. Biochem. 58:57-62.

Gregory, E. M., B. J. Vetri, D. L. Wagner, and T. D. Wilkins. 1977. Carbohydrate repression of catalase synthesis in Bacteriodes fragilis. J. Bacteriol. 129:534-535.

Grosjean, H., and W. Fiers. 1982. Preferential codon usage in prokaryotic genes: the optimal codon-anticodon interaction energy and the selective codon usage in efficiently expressed genes. Gene 18:199-209.

Gottesman, S. 1984. Bacterial regulation: global regulatory networks. Ann. Rev. Genet. 18:415-441.

Haddock, B. A., and C. W. Jones. 1977. Bacterial Respiration. Bacteriol. Rev. 41:47-99.

Hagensee, M. E. and R. E. Moses. 1986. Repair response of Escherichia coli to hydrogen peroxide DNA damage. J. Bacteriol. 168: 1059-1065.

Halliwell, B. and J. M. C. Gutteridge. 1985. Free Radicals in Biology and Medicine. Oxford University Press, New York.

Halliwell, B. D. A. Rowley, and J. M. C. Gutteridge. 1983. Transition metal catalysis and oxygen radical reactions. In Life Chemistry Reports Supplement 2 (Oxidative damage and Related Enzymes-EMBO Workshop 1983) PP 8-14.

Halliwell, B. 1982. Superoxide and superoxide-dependent formation of hydroxyl radicals are important in oxygen toxicity. Trends Biochem. Sci. 7:270-272.

Harley, C. B. and R. P. Reynolds. 1987. Analys is of E. coli promoter sequences. Nucl. Acids Res. 15:2343-2361.

Hartig, A. and H. Ruis. 1986. Nucleotide sequence of Saccharomyces cerevisiae CTT1 gene and deduced amino-acid sequence of yeast catalase T. Eur. J. Biochem. 160:487-490.

Hassan, H. M. and I. Fridovich. 1978. Regulation of the synthesis of catalase and peroxidase in Escherichia coli. J Biol. Chem. 253: 6445-6450.

Hassan, H. S. and I. Fridovich. 1980. Mechanism of the antibiotic action of pyocyanine. J. Bacteriol. 141:156-163.

Herbert, D. and J. Pinsent. 1948. Crystalline bacterial catalase. Biochemical J. 43:193-202.

Hershfield, V., H. W. Boyer, C. Yanofsky, M. A. Lovett, and D. R. 
Helinski. 1974. Plasmid coleq as a molecular venicle for cloning and amplification of DNA. Proc. Natl. Acad. Sci. USA $71: 3455-3459$.

Himelbloom, B. H. and H. M. Hassan. 1986. Effects of cysteine on growth, protease production, and catalase activity of Pseudomanas fluorescens. Appl. Environ. Microbiol. 51:418-421.

Hindley, J. and R. Staden. 1983. DNA Sequencing. (T. S. Work, and R. H. Burdon, eds.) Elsevier Biomedical Press, N.Y., N.Y.

Hopp, T. P. and K. R. Woods. 1981. Prediction of protein antigenic determinants from amino acid sequences. Proc. Natl. Acad. Sci. USA 78:3824-3828.

Ikemura, T. and H. Ozeki. 1982. Codon usage and transfer RNA contents: organism-specific condon-choice patterns in reference to the isoacceptor contents. Cold Spring Harbor symp. Quant. Biol. 47: 1087-1097.

Imlay, J. A., and S. Linn. 1986. Bimodal pattern of killing of DNArepair-defective or anoxically grown Escherichia coli by hydrogen peroxide. J. Bacteriol. 166:519-527.

Jacob, G. S., and W. H. Orme-Johnson. 1979. Catalase of Neurospora crassa. 1. Induction, purification, and physical properties. Biochemistry 18:2967-2975.

Joenje, H., P. Van Der Valk, J. J. P. Gille, F. Arwert, E. H. A. Poll, M. L. Kwee, D. Lindhout, A. S. Eriksson, and J. Van Rijn. 1983. Oxygen-dependent genetic damage. In Life Chemistry Reports Supplement 2 (Oxidative Damage and Related EnzymesEMBO Workshop 1983) p. 309-317.

Johnson, K. R., W. M. Nauseef, A. Care, M. J. Wheelock, S. Shane, S. Hudson, H. P. Koeffler, M. Selsted, C. Miller, and G. Rovera. 1987. Characterization of CDNA clones for human myeloperoxidase: predicted amino acid sequence and evidence for multiple mRNA species. Nucl. Acids Res. 15:2013-2028.

Jones-Mortimer, M. C. 1973. Mapping of structural genes for the enzymes of cysteine biosynthes is in Escherichia coli $k 12$ and Salmonella typhimurium LT2. Heredity 31:213-221.

Jones-Mortimer, M. C. 1968. Positive control of sulphate reduction in Escherichia coli. Biochem. J. 110:589-595.

Jouve, H. M., J. Gaillard, and J. Pelmont. 1984. characterization and spectral properties of Proteus mirabilis PR catalase. Can. J. Biochem. Cell Biol. 62:935-944.

Kirkman, H. N., and G. F. Gaetani. 1984. Catalase: a tetrameric enzyme with four tightly bound molecules of NADPH. Proc. Natl. Acad. Sci. USA $81: 4343-4347$. 
Kono, Y., and 1. Fridovich. 1983a. Functional significance of Mncatalase in Lactobacillus plantarum. J. Bacteriol. 155:742-746.

Kono, Y., and 1. Fridovich. 1983b. Isolation and characterization of the pseudocatalase of Lactobacillus plantarum. a new manganesecontaining enzyme. J. Biol. Chem. 258:6015-6019.

Kramer G. F., and B. N. Ames. 1987. Oxidative mechanisms of toxicity of low-intensity near UV-light in Salmonella typhimurium.

J. Bacteriol, 169:2259-2266.

Kranz, R. G., C. A. Barassi, and R. B. Gennis, 1984. Immunological analysis of the heme proteins present in aerobically grown Escherichia coli. J. Bacteriol. 158:1191-1194.

Laermli, U. K. 1970. Cleavage of structural proteins during the assembly of the nead of bacteriophage T4. Nature (London) $227: 680-685$.

Layne, E. 1957. Spectrophotometric and turbidimetric methods for measuring proteins. Methods Enzymol. 3:447-454.

Lee, P. C., B. R. Bochner, and B. N. Ames. 1983. AppppA, heat-shock, stress, and cell oxidation. Proc. Natl. Acad. Sci. USA 80: 7496-7500.

Levin, D. E., M. Hollstein, M. F. Christman, E. A. Schwiers, and B. N. Ames. 1982. A new Salmonella tester strain (TAl02) with A.T base pairs at the site of mutation detects oxidative mutagens. Proc. Natl. Acad. Sci, USA 79:7445-7449.

Levine S. A. 1977. Isolation and characterization of catalase deficient mutants of Salmonella typhimurium. Molec. Gen. Genet. 150: 205-209.

Loewen, P. C., and J. Switala. 1986. Purification and characterization of catalase HPII from Escherichia coli K12. Biochem. Cell Biol. $64: 638-646$.

Loewen, P. C., J. Switala, and B. L. Triggs-Raine. 1985a. Catalases HPI and HPII in Escherichia coli are induced independently. Arch. Biochem. Biophys. 243:144-149.

Loewen, P. C., B. L. Triggs, C. S. George, and B. E. Hrabarchuk. 1985b. Genetic mapping of katG a locus that affects synthesis of the bifunctional catalase-peroxidase hydroperoxidase 1 in Escherichia coli. J. Bacteriol. 162:661-667.

Loewen, P. C. 1984. Isolation of catalase-deficient Escherichia coli mutants and genetic mapping of katE, a locus that affects catalase activity. J. Bacteriol. 157:622-626.

Loewen, P. C., and B. L. Triggs, 1984. Genetic mapping of KatF, a locus 
that with katE affects the synthesis of a second catalase species in Escherichia coli. J. Bacteriol. 160:668-675.

Loewen, P. C., B. L. Triggs, G. R. Klassen, and J. H. Weiner. 1983. Identification and physical characterization of a ColEl hybrid plasmid containing a catalase gene of Escherichia coli. Can. J. Biochem. Cell Biol. 61:1315-1321.

Maloy, S. R., and W. D. Nunn. 1981. Selection for loss of tetracycline resistance by Escherichia coli. J. Bacteriol. 145:1110-1112.

Maniatis, T., E. F. Fritsch, and J. Sambrook. 1982. Molecular Cloning. A laboratory manual. Cold Spring Harbor Laboratory, Cold Spring Harbor, N.Y.

Margoliash, E., A. Novogrodsky, and A. Schejter. 1960. Irreversible reaction of 3-amino-1:2:4:-triazole and related inhibitors with the protein of catalase. $74: 339-348$.

Mayer, B. K., and J. O. Kalkinbam III. 1986. Catalase (EC.1.11.1.6) activity and its heat inactivation for differentiation of Mycobacterium avium, Mycobacterium intracellulare and Mycobacterium scrofulaceum. Int. J. System. Bacteriol. 36: 207-212.

Mayer, H., R. Grosschedl, H. Schütte, and G. Hobom. 1981. Clal, a new restriction endonuclease from Caryophanon latum L. Nucl. Acids Res. 9:4833-4845.

Mccormick, J.P., J. R. Fischer, J. P. Pachlatko, and A. Eisenstark. 1976. Characterization of a cell-lethal product from the photooxidation of tryptophan: hydrogen peroxide. Science 191:468-469.

Meir, E., and E. Yagil. 1985. Further characterization of the two catalases in Escherichia coli. Curr. Microbiol. 12:315-320.

Meir, E., and E. Yagil. 1984. Catalase-negative mutants of Escherichia coli. Curr. Microbiol. 10:13-18.

Melik-Adamyan, W. R., V. V. Barynin, A. A. Vagin, V. V. Borisov, B. K. Vainshtein, 1. Fita, M. R. N. Murthy, and M. G. Rossmann. 1986. Comparison of beef liver and Penicillium vitale catalases. J. Mol. Biol. 188:63-72.

Miller, J. H. 1972. Experiments in Molecular Genetics. Cold Spring Harbor Laboratory. Cold Spring Harbor, N.Y.

Mitchell, P. 1979. Keilin's respiratory chain concept and its chemiosmotic consequences. Science 206:1148-1159.

Moody, C. S., amd H. M. Hassan. 1982. Mutagenicity of oxygen free radicals. Proc. Natl. Acad. Sci. USA 79:2855-2859.

Morgan, A. R., R. L. Cone and T. M. Elgert. 1976. The mechanism of DNA 
strand breakage by $v i$ tamin $C$ and superoxide and the protective roles of catalase and superoxide dismutase. Nucl. Acids Res. 3:1139-1149.

Morgan, R. W., M. F. Christman, F. S. Jacobson, G. Storz, and B. N. Ames. 1986. Hydrogen peroxide-inducible proteins in Salmonella typhimurium overlap with heat shock and other stress proteins. Proc. Nati. Acad. Sci. USA 83:8059-8063.

Murthy, M. R. N., T. J. Reidlll, A. Sicignano, N. Tanaka, and M. G. Rossmann. 1981. Structure of beef liver catalase. J. Mol. Biol. 152:465-499.

Moss, D. W. 1982. Isoenzymes, Chapman and Hall, New York, N. Y.

Nadler, V., I. Goldberg, and A. Hochman. 1986. Comparative study of bacterial catalases. Biochim. Biophys. Acta 882:234-241.

Nahmias, J. A. and G. C. Bewley. 1984. Characterization of catalase purified from Drosophila melanogaster by hydrophobic interaction chromatography. Comp. Biochem. Physiol. 778:355-364.

Nies, D., and H. G. Schlegel. 1982. Catalase from Comamonas compransoris. J. Gen. Appl. Microbiol. 28:311-319.

Ono, M., and M. Kuwano. 1978. Mutation affecting the thermolability of the 50 s ribosomal subunit in Escherichia coli. J. Bacteriol. $134: 677-679$.

Osumi, T., H. Ozasa, S. Miyazawa, and T. Hashimoto. 1984. Molecular cloning of cDNA for rat liver catalase. Biochem. Biophys. Res. commun. 122:831-837.

Ota, A., 1986. Properties of catalase activity in vegetative and sporulating cells of yeast Saccharomyces cerevisiae. J. Cell. Biochem. 30:331-339.

Padgett, P. J., and N. R. King. 1986. Factors relating to the aerotolerance of spirillum volutans. Can J. Micro. 32:548-552.

Patterson, L. K. 1981. Studies of radiation induced peroxidation in fatty acid micelles. In Oxygen and Oxy-radicals in chemistry and Biology. (M. A. J. Rodgers and E. L. Powers, eds.) Academic Press: New York.

Pearson, M. L. 1972. The role of adenosine 3'5'-cyclic monophosphate in the growth of bacteriophage lambda. Virology 49:605-609.

Platt, T., and D. G. Bear. 1983. Role of RNA polymerase, factor, and $r$ ibosomes in transcription termination. In Gene Function in Procaryotes. (J. Beckwith, J. Davies, and J. A Gallant, eds,), Cold Spring Harbor, New York. pp 123-161.

Price, N. C., and L. Stevens, 1982. Fundamentals of Enzymology. Oxford 
University Press, New York.

Quan, F., R. G. Korneluk, M. B. Tropak, and R. A. Gravel. 1986. I solation and characterization of the human catalase gene. Nucl. Acids Res. 14:5321-5333.

Richter, H. E., and P. C. Loewen. 1982. Catalase synthes is in Escherichia coli is not controlled by catabolite repression. Arch. Biochem. Biophys, 215:72-77.

Richter, H. E., and P. C. Loewen. 1981. Induction of catalase in Escherichia coli by ascorbic acid involves hydrogen peroxide. Biochem. Biophys. Res. Commun. 100:1039-1046.

Riley, M., and A. Anilionis. 1978. Evolution of the bacterial genome. Ann Rev. Microbiol. 32:519-560.

Rørth, M., and P. K. Jensen. 1967. Determination of catalase activity by means of the Clark oxygen electrode. Biochim. Biophys. Acta. 139:174-173.

Rosenberg, M. and D. Court. 1979. Regulatory sequences involved in the promotion and termination of RNA transcription. Ann. Rev. Genet. 13:319-353.

Rupp, W. D., C. E. Wilde $\| / 1$, D. L. Reno, and P. Howard-Flanders. 1971. Exchanges between DNA strands in ultraviolet-irradiated Escherichia coli J. Mol. Biol. 61:25-44.

Sabe, H., T. Miwa, T. Kodaki, K. Izui, S. Hiraga, and H. Katsuki. 1984. Molecular cloning of the phophoenolpyruvate carboxylase gene, $p p c$, of Escherichia coli. Gene 31:279-283.

Sammartano, L. J., R. W. Tuveson, and R. Davenport. 1986. Control of sensitivity to inactivation by $\mathrm{H}_{2} \mathrm{O}_{2}$ and broad-spectrum near-UV radiation by the Escherichia coli katf locus. J. Bacterio1. 168:13-24.

Sammartano, L. J., and R. W. Tuveson. 1984. The effect of exogenous catalase on broad-spectrum near-UV (300-400 nm) treated Escherichia coli cells. Photochem. Photobiol. 40:607-612.

Sancar, A., A.M. Hack, and W. D. Rupp. 1979. Simple method for identification of plasmid-coded proteins. J. Bacteriol. 137:692-693.

Sato. S., Y. Nakada, and K. Nakazawa-Tomizawa. 4987. Amino-acid sequence of a tetrameric, manganese superoxide dismutase from Thermus thermophilus HB8. Biochim. Biophys. Acta 912:178-184.

Schonbaum, G. R., and B. Chance. 1976. Catalase. In The Enzymes ( P. D. Boyer, ed.) Academic Press, N. Y. 13:363-408.

Schreir, P. H., and R. Cortese. 1979. A fast and simple method for 
sequencing DNA cloned in the single-stranded bacteriophage M13. J. Mol. Biol. 129:169-172.

Schroeder, W. A., J. R. Shelton, J. B. Shelton, B. Robberson, G. Apell, R. S. Fang, and J. Bonaventura. 4982a. The complete amino acid sequence of bovine liver catalase and the partial sequence of bovine erythrocyte catalase. Arch. Biochem. Biophys. $214: 397-424$.

Schroeder, W. A., J. R. Shelton, J. B. Shelton, G. Apell, L. Evans, J. Bonaventura, and R. S. Fang. 1982b. The partial amino acid sequence of human erythrocyte catalase. Arch. Biochem.

Biophys. 214:422-424.

Schroeder, W. A., J. R. Shelton, J. B. Shelton, and B. M. Olson. 1964. Some amino acid sequences in bovine liver catalase. Biochem. Biophys. Acta 89:47-65.

Seah, T. C. M., A. R. Bhatti, and J. G. Kaplan. 1973. Novel catalatic proteins of bakers' yeast 1 . an atypical catalase. Can. J. Biochem. 51:1551-1555.

Seah, T. C. M., and J. G. Kaplan. 1973. Purification and properties of the catalase of baker's yeast. J. Biol. Chem. 248: 2889-2893.

Selker, E., K. Brown, and C. Yanofsky. 1977. Mitomycin C-induced expression of trpA of Salmonella typhimurium inserted into the plasmid colEl. J. Bacteriol. 129:388-394.

Shpaer, E. G. 1986. Constraints on codon context in Escherichia coli genes. Their possible role in modulating the efficiency of translation. J. Mol. Biol. 188:555-564.

Sies H., M. F. Christman, G. Storz, and B. N. Ames. 1987. Role of the oxyR reguion in spontaneous mutagenesis. In press.

Silhavy, T. J., M. L. Berman, and L. W. Enquist. 1984. Experiments with Gene Fusions. Cold Spring Harbor Laboratory, Cold Spring Harbor, N.Y.

Skadsen, R. W., and J. G. Scandalios. 1986. Evidence for processing of maize catalase 2 and purification of its messenger RNA aided by translation of antibody-bound polysomes. Biochemistry 25:2027-2032.

Smolenski, M. 1986. Cloning and Partial Characterization of Three katG Mutants from Escherichia coli. MSc Thesis. University of Manitoba.

Steers, E., G. R. Craven, and C. B. Anfinsen. 1965. Evidence for nonidentical chains in the -galactosidase of Escherichia colik12. J. Biol. Chem. 240:2478-2484.

Stephens, J. C., S. W. Artz, and B. N. Ames. 1975. Guanos ine 5'- 
diphosphate $3^{\prime}$-diphosphate (DPGPD): Dositive effector for histidine operon transcription nad general signal for amino acid deficiency. Proc. Natl. Acad. Sci. USA 72:4389-4393.

Sulebele, G. A., and D. V. Rege. 1968. The nature of the glucose effect on the induced synthes is of catalase in saccharomyces cerevisiae. Enzymologia $36: 321-334$.

Sutcliffe, J. G. 1978. pBR322 restriction map derived from the DNA sequence: accurate DNA size markers up to 4361 nucleotide pairs long. Nucl. Acids Res. 5:2721-2728.

Teo, I., B. Sedgwick, M. W. Kilpatrick, T. V. McCarthy, and T. Lindahl. 1986. The intracellular signal for induction of resistance to alkylating agents in $E$. coli. Cell 45:315-324.

Touati, D. 1987. in press.

Triggs-Raine, B. L., and P. C. Loewen. 1987. Physical characterization of katG encoding catalase HPI of Escherichia coli. Gene 52:124128.

Tsunasawa, S., and F. Sakiyama. 1984. Amino-terminal acetylation of proteins: an overview. Methods in Enzymol. 106:165-170.

Tuveson, R. W., and L. J. Sammartano. 1986. Sensitivity of hemA mutant Escherichia coli cells to inactivation by near-uv light depends on the level of supplementation with $\delta$-aminolevulinic acid. Photochem. Photobio1. 43:621-626.

Tuveson, R. W. 1981. The interaction of a gene (nur) controlling nearUV sensitivity and the polAt gene in strains of E. coli K12. Photochem. Photobiol. 33:919-923.

Twigg, A. J., and D. Sherratt. 1980. Trans-complementable copy-number mutants of plasmid colel. Nature 283:216-248.

Tyrrell, R. M. 1985. A cormon pathway for protection of bacteria against damage by solar UVA (334 nm, $365 \mathrm{~nm})$ and an oxidizing agent $\left(\mathrm{H}_{2} \mathrm{O}_{2}\right)$. Mutat. Res. 145:129-136.

Vainshtein, B. K., W. R. Melik-Adamyan, V. V. Barynin, A. A. Vagin, A. I. Grebenko, V. V. Borisov, K. S. Bartels, I. Fita, and M. G. Rossmann. 1986. Three-dimensional structure of catalase from Penicillium vitale at 2.0 A resolution. J. Mol. Biol. 188:49-61.

Van Hermen, J. J., and W. J. A. Meuling. 1975. Inactivation of biologically active DNA by $y$-ray-induced superoxide radicals and their dismutation products singlet molecular oxygen and hydrogen peroxide. Biochim. Biophys. Acta 402:133-141.

Vassilyadi, M., and Archibald, F. 1985. Catalase, superoxide dismutase, and the production of $\mathrm{O}_{2}$-sensitive mutants of Bacillus coagulans. 
Can. J. Microbiol. 31:994-999.

Vogelstein, B., and D. Gillespie. 1979. Preparative and analytical purification of DNA from agarose. Proc. Natl. Acad Sci., USA $76: 645-649$.

Way, J. C., M. A. Davis, D. Morisato, D. E. Roberts, and N. Kleckner. 1984. New Tn10 der ivatives for transposon mutagenes is and for construction of lacZ operon fusions by transposition. Gene 32: 369-379.

Watson, J. D., N. H. Hopkins, J. W. Roberts, J. A. Steitz, and A. M. Weiner. 1987. Molecular Biology of the Gene. The Benjamin/Cummings Publishing Company, Inc. Don Mills, Ontario.

Winquist, L., U. Rannug, A. Rannag, and C. Ramel. 1984. Protection from toxic and mutagenic effects of hydrogen peroxide by catalase induction in Salmonella typhimurium. Mutat. Res. 141:145-147.

Winterbourn, C. C. 1983. Biological mechanisms of hydroxyl radical production. In Life Chemistry Reports Supplement 2 (Oxidative Damage and Related Enzymes-EMBO Workshop 1983) pp. 1-7.

Worcel, A., and E. Burgi. 1974. Properties of a membrane-attached form of the folded chromosome of Escherichia coli. J. Mol. Biol. $82: 91-105$.

Wu, T. T. 1966. A model for three point analys is of random general transduction. Genetics 54:405-410.

Yanisch-Perron, C., J. Vieira, and J. Messing. 1985. Improved M13 phage cloning vectors and host strains: nucleotide sequences of the M13mp18 and puc19 vectors. Gene 33:103-119.

Yonei, S., R. Yokota, and Y. Sato. 1987. The distinct role of catalase and DNA repair systems in protection against hydrogen peroxide in Escherichia cali. Biochem. Biophys. Res. Commun. 143: $638-644$.

Yoshpe-Purer, Y., Y. Henis, and J. Yashphe. 1977. Regulation of catalase level in Escherichia coli K12. Can J. Microbiol. 23:84-91.

Yoshpe-Purer, Y., and Y. Henis. 1976. Factors affecting catalase level and sensitivity to hydrogen peroxide in Escherichia coli. Appl. Environ. Micro. 32:465-469.

Yousten, A. A., J. L. Johnson, and M. Salin. 1975. Oxygen metabolism of catalase-negative and catalase-positive strains of Lactobacillus plantarum. J. Bacteriol. 123:242-247. 